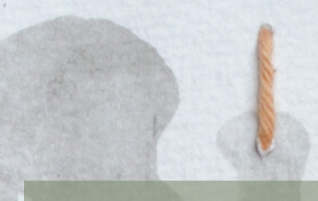

AN INTEGRATIVE APPROACH

TOREDUCING

land, water, and carbon footprint OF GLOBAL

ENERGY CONSUMPTION IN THE TRANSPORT SECTOR 



\section{AN INTEGRATIVE APPROACH TO REDUCING LAND, WATER, AND CARBON FOOTPRINT OF GLOBAL ENERGY CONSUMPTION IN THE TRANSPORT SECTOR}





\title{
AN INTEGRATIVE APPROACH TO REDUCING LAND, WATER, AND CARBON FOOTPRINT OF GLOBAL ENERGY CONSUMPTION IN THE TRANSPORT SECTOR
}

\section{DISSERTATION}

\author{
to obtain \\ the degree of doctor at the University of Twente, \\ on the authority of the rector magnificus, \\ Prof. dr. T.T.M. Palstra, \\ on account of the decision of the Doctorate Board, \\ to be publicly defended \\ on Thursday 26 November 2020 at 14:45
}

by

Bunyod Usmanovich Holmatov

born on 5 May 1984

in Kokand, Uzbekistan 
This dissertation has been approved by:
Dr. M. S. Krol
supervisor
Dr. J. F. Schyns
co-supervisor

This research received funding from the European Union's Horizon 2020 research and innovation programme under Grant Agreement No. 689669 (MAGIC).

This research was conducted under the auspices of the Graduate School for SocioEconomic and Natural Sciences of the Environment (SENSE).

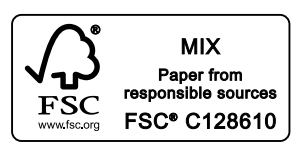

Cover artwork: (c) Nicole Schyns 2020.

Printed by: Ipskamp Printing, Enschede.

ISBN: 978-90-365-5081-9

DOI: $10.3990 / 1.9789036550819$

(C) 2020 Bunyod Holmatov, The Netherlands. All rights reserved. No parts of this thesis may be reproduced, stored in a retrieval system or transmitted in any form or by any means without permission of the author. Alle rechten voorbehouden. Niets uit deze uitgave mag worden vermenigvuldigd, in enige vorm of op enige wijze, zonder voorafgaande schriftelijke toestemming van de auteur. 


\section{Graduation Committee:}

Chairman / secretary

Supervisor:

Co-supervisor:

Committee Members
Prof. dr.ir. H.F.J.M. Koopman

Dr.ir. M.S. Krol

Dr. J.F. Schyns

Prof. dr. ir. T.H. van der Meer

Prof. dr. A.A. Voinov

Dr. M.S. Krol

Dr. ir. J.F. Schyns

Prof. dr. K.S. Hubacek

Prof. dr. D.P. van Vuuren

Dr. ir. S. Nonhebel

Dr. M. Raugei

Dr. M.J. Arentsen 



\section{Table of Contents}

Acknowledgements ..........................................................................................................

Summary ...................................................................................................... iii

Samenvatting.....................................................................................................................vi

1. Introduction .......................................................................................................

2. Land, Water and Carbon Footprints of Circular Bioenergy

Production Systems ............................................................................................6

3. The Environmental Footprint of Transport by Car Using

Renewable Energy .................................................................................................... 30

4. EU's bioethanol potential from wheat straw and maize stover and the environmental footprint of residue-based bioethanol ...................... 35

5. Biofuels for transport: global lignocellulosic bioethanol production potential and its environmental - land, water and carbon footprint ......................................................................................................................... 51

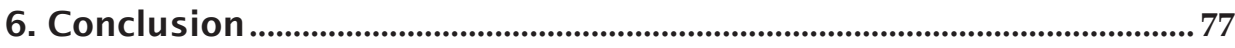

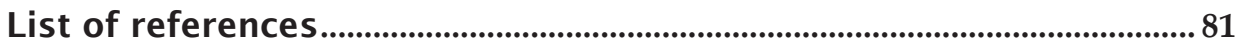

Appendix A: An Appendix to Chapter 2.................................................. 105

Appendix B: An Appendix to Chapter 3 …………………………................. 117

Appendix C. An Appendix to Chapter 4 …………...........................................118

Appendix D. An Appendix to Chapter 5............................................................119 



\section{Dedication}

This dissertation is dedicated to the memory of Prof. dr. ir. A. Y. Hoekstra. I gratefully acknowledge inspiration, initiative and guidance of A. Y. Hoekstra in conceptualizing this doctoral thesis. He passed away on November 18, 2019.

\section{Acknowledgements}

I would like to express my outmost gratitude to Arjen Y. Hoekstra and Maarten S. Krol for their support and guidance in completing this thesis. Arjen's vision, critical and sharp mind, quick problem solving ability, dedication and commitment to students, and positive mindset gave me confidence to take control of my PhD journey. Arjen Y. Hoekstra passed away unexpectedly in November of 2019 before the completion of this thesis. Maarten, thank you for stepping up at the time of undue hardship and projecting the unwavering confidence that helped to keep my focus and navigate the uncertainty and changes inflicted by the sudden passing of Arjen. You stood by me during the entire program and having your broad knowledge, calm and diplomatic posture, and receptiveness to meet and discuss any issues at any time was a true blessing.

I would like to also thank Joep Schyns who agreed to step up to fill the management gap imposed by the unfortunate circumstances. Joep, your fresh experience with doctoral defence and dissertation formalities as well as your data management skills were indispensable in completing this thesis within the planned timeframe.

I thank many colleagues and my office mates. Special acknowledgements to Lara, Alejandro, and Hatem. I enjoyed sharing the office with you and having conversations about life in general and about the joys and downfalls of being a researcher in the Netherlands. Lara, I sincerely appreciate all the positivity stemming from you despite the circumstances and for insightful tips and lessons on European politics, history and culture. I also thank you, Sara, for being our "extended" office mate, coming to check in every time you passed by, for many fond memories and sharing stories of your cat. Moreover, I would like to thank the Earth@lternatives crew for sticking together during the difficult times. Certainly, I extend my gratitude to Joke for taking care of all the administrative and organizational tasks so that I could focus on my research. Lara and Beau, thank you for agreeing to be my paranymphs during the defense ceremony.

My special acknowledgement goes to my American family and friends: Robin, Steven, Chick, Barbara, Nancy, Clint, and Briana. From a boy who could barely speak English to obtaining the title of a $\mathrm{PhD}$, this journey would not have been possible without your support and encouragement. I thank you from the bottom of my heart. I came far and looking back I realize that it was a blessing to meet and get to know you. I really wish you could have joined me on the occasion of my public defense.

Finally, I thank my extended family and friends for their encouragements and support. My parents (Usmanjon and Firdauskhon), brothers (Bakhodir and Bakhrom), wife (Madina), son (Amir) and daughter (Azima). You each had a crucial role to play in my life and professional journey. Thank you very much. Thank you Madina for your continuous 
support and for taking good care of our family, including the isolation period of COVID19. I recognize your sacrifice and support despite all the uncertainty. Thank you, Amir and Azima, for being amazing children and filling my life with joy. I love you all very much. 


\section{Summary}

Water, land, carbon and energy are closely connected by links that are widely recognized but sparsely studied and not sufficiently quantified. More studies focus on quantifying the carbon footprint of different energy sources than on quantifying their land and water footprints. However, land and water footprints of renewable energy sources are becoming key determinants of their long-term sustainability and acceptability. Generally, as a tradeoff for having smaller carbon footprint, the land and water requirements of renewable energy sources are larger compared to fossil fuels.

Fossil fuels are currently the dominant energy source in all sectors of the global economy and their use leads to the emission of greenhouse gases (GHG) that are causing climate change. Among the different sectors, the transport sector is a unique case in the sense that it emits a quarter of GHGs but transitioning to low-carbon technologies is very challenging for at least two reasons: (1) to be viable, the energy density of transport fuels needs to be high and this limits the choice of alternative fuels that can be used in the transport sector; and (2) the highly developed infrastructure for fossil fuels production, distribution and usage in the existing fleet of transport modes makes infiltration of renewable energy difficult.

The overarching objective of this research is to contribute to the discourse concerning the energy transition to low-carbon fuels in the transport sector in order to meet climate targets, while considering the land and water implications of alternative fuels. This is achieved in two stages: (1) use the footprint concept to calculate the land, water and carbon footprints of conventional vs advanced biofuels to estimate the scale of emission reduction per unit of energy and the scale of land and water resources required as a tradeoff; and (2) estimate the global biofuel production potential under different sustainability criteria. In this dissertation, the two stages are broken into four subsequent studies, found in Chapters 2-5. For stage one, I estimate the land, water and carbon footprints of various alternative fuels and electricity, covered in Chapters 2-5. For stage two, I estimate the lignocellulosic bioethanol production potential under different sustainability criteria in the European Union (Chapter 4) and at the global scale (Chapter 5). In addition, I work in reverse order to calculate the extent of the GHG emission reductions and the land, water implications of meeting a given energy target using crop-based bioenergy (Chapter 2).

\section{Land, Water and Carbon Footprint of Circular Bioenergy Production Systems.}

The aim of this study is to estimate the scale of water and land resources necessary to meet global energy demand with bioenergy produced in a circular system (self-sustaining system where the output is used as input) while estimating associated greenhouse gas (GHG) emissions. The land, water and carbon footprint of net bioelectricity, bioethanol and biodiesel are calculated assuming different crop feedstocks and two scenarios: a 100\% shift to bioenergy and a 9.8\% shift to bioenergy (adapted from the International Energy Agency's sustainable development scenario). The distinction between the net and gross energy yield is determined by subtracting energy inputs in the production from gross energy outputs. The results show that the footprints vary based on the type of energy 
output (i.e., heat vs electricity vs fuel), and crop feedstock. In comparative terms, producing combined heat and power results in the smallest footprints per unit of energy output. In terms of biofuels, bioethanol has a smaller land, water and carbon footprint when compared to biodiesel. Although shifting to bioenergy can lead to GHG emission savings, it comes with high costs in land and water. While the $100 \%$ shift to bioenergy is not possible from water and land perspectives, even obtaining an additional $9.8 \%$ of the final energy demand from a mix of bioelectricity, heat and biofuels would require $11-14 \%$ of the global arable land and a water flow equivalent to $18-25 \%$ of the global water footprint of humanity.

\section{The Environmental Footprint of Transport by Car Using Renewable Energy.}

Various innovations are emerging to limit GHG emissions from the transport sector, but these are not equally efficient when their impact on land and water resources are considered. The aim of this study is to calculate and compare the land, water and carbon footprints of midsize cars utilizing various fuels and electricity, per unit of distance. Specifically, the land, water and carbon footprint per unit of travelled distance is compared across vehicles utilizing: (a) gasoline; (b) B20 - a blend of $20 \%$ biodiesel from rapeseed and 80\% conventional diesel; (c) E85 - a blend of 85\% bioethanol from sugar beet and 15\% conventional gasoline; (d) bioelectricity; (e) electricity from solar PV; and (f) hydrogen from solar PV. The results show that solar-powered battery electric vehicles have the smallest environmental footprint per $\mathrm{km}$ while a vehicle utilizing a biodiesel blend with conventional diesel has the largest environmental footprint per $\mathrm{km}$, including larger GHG emission compared to the emissions of gasoline based vehicles. The appropriate choice of future transport is thus diffusion of electric and hydrogen vehicles.

\section{EU's bioethanol potential from wheat straw and maize stover and the environmental footprint of residue-based bioethanol.}

Similarly to many other regions and countries, the European Union (EU) has targets for decarbonizing its transport sector. By 2030, the EU seeks to obtain a minimum of $3.5 \%$ of transport sector's energy consumption from biofuels produced using renewable biological sources such as crop residue. The aim of this study is to (a) calculate the residue-based bioethanol production potential in the EU; and (b) calculate and compare the land, water and carbon footprints of residue-based bioethanol from wheat straw and maize stover across 27 EU member states. To avoid adverse effects from removal of crop residues, this study assumes maximum harvestable shares of $50 \%$ for maize stover and $40 \%$ for wheat straw. Findings reveal that the bioethanol production potential in the EU is $470 \mathrm{PJ}$ as gross yield (404 PJ as net), which falls short of the EU's 3.5\% target by 2030 but can replace about $3.4 \%$ of EU's current energy consumption in the transport sector. Also the average carbon footprints per unit of residue-based bioethanol are small (19.4 vs $19.6 \mathrm{~g} \mathrm{CO}_{2} \mathrm{eq} \mathrm{MJ}{ }^{-1}$ for wheat straw vs maize stover), but the land and water footprints are comparable to the footprints of conventional bioethanol. Thus, decisions in promoting residue-based bioethanol should assess bioethanol's impact on land and water resources carefully to avoid unexpected issues down the line. 


\section{Biofuels for transport: global lignocellulosic bioethanol production potential and its environmental footprint.}

Bioethanol production technology from non-crop lignocellulosic material is one of the few "advanced" (meaning non-crop based) biofuel technologies that has reached the commercial scale and is advocated as a viable solution to decarbonize the transport sector. The aims of this study are to (a) estimate the global bioethanol production potential using all crop residues in all countries with and without restrictions on their harvest (theoretical vs sustainable potential); and (b) assess the environmental footprint of advanced bioethanol across crops, countries, and potentials. Due to data limitations, the final number of crop residues covered in this study is limited to 123 (out of 160 primary crops reported by the FAOSTAT), which covers $98.8 \%$ of the total primary crop area reported by FAOSTAT across 192 countries and 20 territories. The results show that advanced bioethanol from crop residues can replace only a small share of energy from oil products consumed in the transport sector: $31 \%$ of oil products assuming no restrictions on the residue harvest (theoretical potential), 13\% assuming that the maximum harvestable residue amount is limited to $50 \%$ (optimistic sustainable potential) and $7 \%$ assuming that the maximum harvestable residue amount is limited to $25 \%$ (realistic sustainable potential). While footprints vary greatly depending on feedstock, country, and potential harvestable ratio, in general, the environmental footprint of advanced bioethanol is larger than the environmental footprint of conventional bioethanol or solar PV electricity or solar PV derived hydrogen, suggesting that switching to the fleet of electric or hydrogen vehicles would be a more logical choice.

\section{Conclusion}

The transport sector is one of the largest GHG emitters and holds a large potential for reducing global GHG emissions by switching to alternative fuels and electricity. This research has shown that the land, water and carbon footprints of alternative fuels and electricity vary greatly according to the output energy type, utilized feedstock, country, and assumptions of availability of feedstock. While an alternative fuel may have a small carbon footprint and help reduce the GHG emissions, its water and land tradeoffs can make it unsuitable to reach large scale production or inferior compared to the range of existing alternatives. Particularly, the environmental footprint of conventional and advanced biofuels suggest that the production and use of biofuels can lead to GHG emission savings but at large cost to land and water resources, while realistically replacing only a small share of energy consumed in the transport sector. The more logical choice is thus diffusion of electric and hydrogen-based vehicle fleets powered with renewable electricity to accelerate decarbonization of the transport sector. 


\section{Samenvatting}

Water, land, koolstof en energie hangen onderling nauw samen. De verbanden daartussen worden weliswaar algemeen erkend, maar weinig bestudeerd en niet voldoende gekwantificeerd. Er zijn meer studies die zich richten op het kwantificeren van de koolstofvoetafdruk van de verschillende energiebronnen dan studies die zich richten op het kwantificeren van de voetafdrukken van land en water. Die land- en watervoetafdruk van hernieuwbare energiebronnen worden echter belangrijke factoren voor het bepalen van de duurzaamheid en aanvaardbaarheid van deze energiebronnen op de lange termijn. In het algemeen gaat de kleinere koolstofvoetafdruk van hernieuwbare energiebronnen in vergelijking met fossiele brandstoffen gepaard met een grotere behoefte aan land en water.

Fossiele brandstoffen vormen momenteel de belangrijkste energiebron in alle sectoren van de wereldwijde economie. Het gebruik ervan leidt tot de uitstoot van broeikasgassen die klimaatverandering veroorzaken. Binnen de diverse sectoren is de transportsector een geval apart: deze is verantwoordelijk voor een kwart van de uitstoot van broeikasgassen, maar de overgang naar koolstofarme technologieën is een grote uitdaging om ten minste twee redenen. (1) Om rendabel te zijn moet de energiedichtheid van transportbrandstoffen hoog zijn en dit beperkt de keuze aan alternatieve brandstoffen die in de transportsector kunnen worden gebruikt. (2) De goed ontwikkelde infrastructuur voor de productie, distributie en het gebruik van fossiele brandstoffen in het bestaande arsenaal aan vervoermiddelen maakt implementatie van hernieuwbare energie moeilijk.

De overkoepelende doelstelling van dit onderzoek is om bij te dragen aan het discours betreffende de energietransitie naar koolstofarme brandstoffen in de transportsector om te voldoen aan de klimaatdoelen, en daarbij de gevolgen voor land en water van alternatieve brandstoffen in beschouwing te nemen. Dit wordt bereikt in twee stappen: door (1) het concept van de voetafdruk te gebruiken om de land-, water- en koolstofvoetafdrukken te berekenen van conventionele versus geavanceerde biobrandstoffen, om de mate van reductie van de uitstoot per eenheid energie in te kunnen schatten, en de schaal van de land- en waterbehoefte die daar tegenover staat; en door (2) het wereldwijde potentieel voor de productie van biobrandstoffen in te schatten aan de hand van verschillende duurzaamheidscriteria. In dit proefschrift zijn deze twee stappen opgedeeld in vier opeenvolgende studies, terug te vinden in de hoofdstukken 2-5. Voor de eerste stap maak ik een inschatting van de land-, water- en koolstofvoetafdrukken van diverse alternatieve brandstoffen en energiebronnen, te vinden in de hoofdstukken 2-5. Voor de tweede stap maak ik aan de hand van verschillende duurzaamheidscriteria een inschatting van het potentieel voor de productie van lignocellulosehoudend bio-ethanol in de Europese Unie (hoofdstuk 4) en op wereldschaal (hoofdstuk 5). Daarnaast neem ik de route in omgekeerde volgorde om te berekenen in welke mate gewasgebaseerde bioenergie, ingezet voor het behalen van een gegeven energiedoel, leidt tot vermindering van de uitstoot van broeikasgassen, en wat de implicaties zijn voor land- en watergebruik (hoofdstuk 2). 
Het doel van deze studie is om een inschatting te maken van de hoeveelheid water- en landvoorraden die noodzakelijk zijn om aan de wereldwijde energiebehoefte te voldoen met bio-energie geproduceerd in een circulair systeem (een zelfvoorzienend systeem waarin de output gebruikt wordt als input) en tegelijkertijd een inschatting te maken van de uitstoot van het betrokken broeikasgas. De land-, water- en koolstofvoetafdruk van netto bio-elektriciteit, bio-ethanol en biodiesel worden berekend uitgaande van verschillende gewassen als grondstoffen en van twee scenario's: een overgang naar $100 \%$ bio-energie en een overgang naar 9,8\% bio-energie (overgenomen van het duurzame ontwikkelingsscenario van het Internationaal Energieagentschap). Het onderscheid tussen netto en bruto energieopbrengst wordt bepaald door het energieverbruik van de productie af te trekken van de bruto energieopbrengst. De resultaten laten zien dat de voetafdrukken variëren naar gelang het soort energieopbrengst (d.w.z. warmte of elektriciteit of brandstof) en het type gewas dat als grondstof wordt gebruikt. Vergeleken met de andere mogelijkheden veroorzaakt de productie van de combinatie van warmte en stroom de kleinste voetafdrukken per eenheid energieopbrengst. Als het gaat om biobrandstoffen heeft bio-ethanol een kleinere land-, water- en koolstofvoetafdruk vergeleken met biodiesel. Hoewel de overgang naar bio-energie kan leiden tot vermindering van de uitstoot van broeikasgassen, is de prijs hiervoor een groot verbruik van land en water. Een 100\% overgang naar bio-energie is niet mogelijk vanuit het perspectief van water- en landverbruik, maar zelfs het bereiken van een toename van $9,8 \%$ van het aandeel van een mix van bio-elektriciteit, warmte en biobrandstoffen aan de totale energiebehoefte zou $11-14 \%$ vereisen van de landbouwgrond wereldwijd en een watertoevoer gelijk aan $18-25 \%$ van de watervoetafdruk van de mensheid wereldwijd.

\section{De ecologische voetafdruk van vervoer met de auto gebruikmakend van hernieuwbare energie}

Er worden diverse innovaties gedaan om de uitstoot van broeikasgassen door de transportsector te beperken, maar deze zijn niet even efficiënt wanneer de impact op landen watervoorraden wordt meegenomen. Het doel van deze studie is om een berekening en een vergelijking te maken van de land-, water- en koolstofvoetafdrukken per eenheid afstand van middelgrote auto's die gebruikmaken van diverse brandstoffen en energiebronnen. Meer specifiek wordt een vergelijking gemaakt van de land-, water- en koolstofvoetafdruk per eenheid afgelegde afstand van voertuigen die gebruikmaken van: (a) benzine; (b) B20 - een mengsel van 20\% biodiesel uit koolzaad en $80 \%$ conventionele diesel; (c) E85 - een mengsel van 85\% bio-ethanol uit suikerbiet en 15\% conventionele benzine; (d) bio-elektriciteit; (e) elektriciteit uit zonnepanelen; en (f) waterstof uit zonnepanelen. De resultaten laten zien dat elektrische voertuigen op zonne-energie de kleinste ecologische voetafdruk per kilometer hebben, terwijl een voertuig dat gebruikmaakt van een biodieselmengsel met conventionele diesel de grootste ecologische voetafdruk heeft per kilometer, inclusief een grotere uitstoot van broeikasgassen vergeleken met de uitstoot van voertuigen op benzine. De adequate keus voor toekomstig 
vervoer is daarmee verdere groei van het aandeel elektrische voertuigen en voertuigen op waterstof.

\section{Het potentieel aan bio-ethanol uit tarwestro en maïsstoppels in de EU en de ecologische voetafdruk van bio-ethanol gebaseerd op restproducten}

Net als vele andere regio's en landen heeft de Europese Unie (EU) doelen gesteld voor het terugdringen van koolstof in de transportsector. De EU streeft ernaar om in 2030 minimaal $3,5 \%$ van het energieverbruik in de transportsector afkomstig te laten zijn uit biobrandstoffen geproduceerd met gebruik van hernieuwbare biologische bronnen zoals gewasresten. Het doel van deze studie is om (a) het potentieel voor de productie van bioethanol gebaseerd op restproducten in de EU te berekenen; en (b) een berekening en een vergelijking te maken van de land-, water- en koolstofvoetafdrukken van bio-ethanol gebaseerd op restproducten van tarwestro en maïsstoppels in 27 EU-lidstaten. Om nadelige effecten van het verwijderen van gewasresten te voorkomen gaat deze studie uit van een maximaal oogstbaar gedeelte van $50 \%$ voor maïsstoppels en $40 \%$ voor tarwestro. De bevindingen tonen dat het potentieel in de EU voor de productie van bio-ethanol 470 PJ bruto-opbrengst is (404 PJ netto). Dit is niet voldoende voor het doel van 3,5\% voor 2030 van de EU, maar kan wel ongeveer 3,4\% van het huidige energieverbruik van de EU in de transportsector vervangen. Daarnaast zijn de gemiddelde koolstofvoetafdrukken weliswaar klein per eenheid bio-ethanol op basis van restproducten (19,4 tegenover 19,6 gr $\mathrm{CO}_{2}$ eq $\mathrm{MJ}^{-1}$ voor tarwestro respectievelijk maïsstoppels), maar de land- en watervoetafdrukken zijn vergelijkbaar met de voetafdrukken van conventionele bioethanol. Daarom moet bij beslissingen om bio-ethanol op basis van restproducten te stimuleren de impact van bio-ethanol op land- en waterbronnen zorgvuldig worden beoordeeld om onverwachte problemen in de toekomst te voorkomen.

Biobrandstoffen voor vervoer: wereldwijd potentieel voor de productie van lignocellulosehoudende bio-ethanol en de ecologische voetafdruk daarvan

De productietechnologie voor bio-ethanol uit niet uit gewas afkomstig lignocellulosehoudend materiaal is één van de weinige "geavanceerde" (in de betekenis: niet op gewas gebaseerde) technologieën voor biobrandstoffen die op commerciële schaal wordt toegepast en wordt gepromoot als een rendabele oplossing om de transportsector koolstofarm te maken. De doelen van deze studie zijn om (a) een inschatting te maken van het wereldwijde potentieel voor de productie van bio-ethanol gebruikmakend van alle gewasresten in alle landen met en zonder de beperkingen van de oogst (theoretisch ten opzichte van duurzaam potentieel); en (b) de ecologische voetafdruk te beoordelen van geavanceerde bio-ethanol voor de verschillende gewassen, landen en potentiëlen. Vanwege beperkte beschikbaarheid van gegevens is het totale aantal gewasresten behandeld in deze studie beperkt tot 123 (van 160 primaire gewassen gerapporteerd door de FAOSTAT), welke samen goed zijn voor $98,8 \%$ van het totale areaal voor primaire gewassen zoals gerapporteerd door FAOSTAT in 192 landen en 20 gebieden. De resultaten laten zien dat geavanceerde bio-ethanol uit gewasresten slechts voor een klein gedeelte het verbruik van energie uit aardolieproducten in de transportsector kan vervangen: $31 \%$ 
van de aardolieproducten uitgaande van een onbeperkte oogst van de gewasresten (theoretisch potentieel), 13\% ervan uitgaande dat de maximaal oogstbare hoeveelheid resten beperkt is tot $50 \%$ (optimistisch duurzaam potentieel) en $7 \%$ ervan uitgaande dat de maximaal oogstbare hoeveelheid resten beperkt is tot $25 \%$ (realistisch duurzaam potentieel). Hoewel voetafdrukken over het algemeen een grote variatie vertonen afhankelijk van grondstof, land en ratio van oogstbaar potentieel, is de ecologische voetafdruk van geavanceerde bio-ethanol groter dan de ecologische voetafdruk van conventionele bio-ethanol of elektriciteit uit zonnepanelen of waterstof geproduceerd met zonnepanelen. Dit suggereert dat een overstap naar elektrische voertuigen of voertuigen op waterstof een meer logische keuze zou zijn.

\section{Conclusie}

De transportsector is een van de grootste factoren in de uitstoot van broeikasgassen en heeft een groot potentieel voor het verminderen van de wereldwijde uitstoot van broeikasgassen, door over te stappen op alternatieve brandstoffen en elektriciteit. Dit onderzoek heeft aangetoond dat de land-, water- en koolstofvoetafdrukken van alternatieve brandstoffen en energiebronnen een grote variatie vertonen afhankelijk van het type energieopbrengst, de gebruikte grondstof, het land en de aannames wat betreft beschikbaarheid van de grondstoffen. Hoewel een alternatieve brandstof een kleine koolstofvoetafdruk kan hebben en kan bijdragen aan het verminderen van de uitstoot van broeikasgassen, kunnen de implicaties voor water- en landverbruik deze brandstof ongeschikt maken voor productie op grote schaal, of inferieur vergeleken met bestaande alternatieven. Meer specifiek, de ecologische voetafdruk van conventionele en geavanceerde biobrandstoffen suggereert dat de productie en het gebruik van biobrandstoffen kan leiden tot een vermindering van de uitstoot van broeikasgassen, maar daar staat een hoog verbruik van land- en watervoorraden tegenover, terwijl deze biobrandstoffen in feite slechts een klein gedeelte van de energie die wordt verbruikt in de transportsector kunnen vervangen. De meer logische keuze is dus de vermeerdering van het arsenaal aan elektrische en op waterstof gebaseerde voertuigen, aangedreven met hernieuwbare elektriciteit, om de terugdringing van het gebruik van koolstof in de transportsector te versnellen. 



\section{Introduction}

\subsection{Energy production and use is the main cause of climate change}

Humans' demand for food, energy and raw materials is rising. Global economic output is strongly linked to the rate of greenhouse gas (GHG) emissions. Increasing cumulative emissions of GHGs linked to human activities is changing the Earth's climate and posing risks for human and natural systems. Without drastic reduction of GHGs by 2030, the global warming is likely to reach $1.5 \mathrm{C}^{\circ}$, further increasing climate-related risks including risks to food security and water supply (IPCC, 2018). The goal to limit global warming to $1.5 \mathrm{C}^{\circ}$ was mentioned at the $16^{\text {th }}$ Conference of Parties (COP) to the United Nations Framework Convention on Climate Change (UNFCCC) in 2010 and formalized as a goal at the COP21 in 2015, known as the Paris Agreement (IPCC, 2018)

Energy-related emissions are the largest source of GHGs. Some two thirds of all GHGs are emitted during energy production and use (IEA, 2015b) and global energy demand is increasingly driven by population growth, industrialization and urbanization (Johansson et al., 2012) in a vicious reinforcing cycle. Decarbonizing the global economy towards reaching the $1.5 \mathrm{C}^{\circ}$ target involves simultaneous transition towards low carbon technologies across all economic sectors with the transport sector being a prime example given (a) its large contribution to GHGs (a quarter of global emissions) (IEA, 2018a) and (b) much lower use of renewables (3.4\% in 2017) compared to the share of renewables in electricity ( $25 \%$ in 2017 ) and heat (10\% in 2018) (IEA, 2018b).

\subsection{Challenges of decarbonizing the transport sector}

Despite the transport sector holding a large potential for reducing global GHG emissions, it is also arguably the most challenging. Over a billion cars (OICA, 2019b), thousands of (passenger, cargo and military) airplanes and ships around the world depend heavily on fossil fuels for energy. Infrastructure for fossil fuels production, distribution and usages in the existing fleet of transport modes is well developed.

Changing transport fuels to hydrogen, biofuels, and electricity is widely promoted as cleaner alternatives for reducing emissions (European Commission, 2018). Such alternatives, however, have compatibility constraints with regards to the current infrastructure (e.g., supply, distribution and internal combustion engines), making some variations of so called "drop-in" biofuels that according to the International Energy Agency are "functionally equivalent to petroleum fuels and are fully compatible with existing petroleum infrastructure" (Karatzos et al., 2014) attractive alternatives. Biofuels are prominently featured in future energy scenarios envisioning deployment of lowcarbon technologies, such as the International Renewable Energy Agency's REMap (IRENA, 2019b), and the International Energy Agency's 2DS scenarios (IEA, 2020a). Bioethanol and biodiesel for example, can be used in any gasoline or diesel based cars if blended with fossil fuels at low ratios, i.e., $<10 \%$ for bioethanol with gasoline and $<7 \%$ for biodiesel with diesel by volume (Karatzos et al., 2014). Despite the large role that biofuels could play in aviation and maritime transport, their current uses are at the incipient stage 
(IEA, 2018b). For example, only one type of aviation biofuel - hydroprocessed esters and fatty acids synthetic paraffinic kerosene fuel has reached commercial maturity but is more expensive compared to fossil based alternatives and the cost reduction through technical learning is limited (IEA, 2018b). Therefore, aviation and maritime biofuels are ignored in this thesis.

In 2017, contribution of renewables in the transport sector was $3.4 \%$ and biofuels made up $92 \%(3,475 \mathrm{PJ})$ of the renewables used in the transport sector (IEA, 2018b). In contrast, diffusion of electric and hydrogen based cars that require major infrastructure development has been slow. Some 5.6 million electric vehicles were in operation in 2019 (ZSW, 2019) which is less than $1 \%$ of the total vehicle fleet while the number of hydrogen based cars was far less, about 11,200 cars in 2018 with 376 refueling stations operating worldwide (IEA, 2019e).

\subsection{Carbon emission savings of biofuels vs land and water consumption}

Biofuels are produced using biomass feedstock that entails land and water requirements. Different generations of biofuels can be identified based on the type of biomass feedstock. Conventional biofuels are produced using food crops (Eisentraut, 2010; Sims et al., 2010) while second generation biofuels use non-food biomass, such as energy crops (e.g., switchgrass) and agricultural residue (Bharathiraja et al., 2017; Rastogi \& Shrivastava, 2017), and third generation biofuels use algae (Gerbens-Leenes et al., 2014). Second and third generation biofuels are often simply called advanced biofuels. Conventional biofuels require a great deal of water (Dominguez-Faus et al., 2009; Gerbens-Leenes et al., 2009b), and land (Rulli et al., 2016) and also affects food prices (Gupta \& Verma, 2015). This makes second and third generation biofuels (non-conventional or "advanced" biofuels) more favorable, but currently they make up only a fraction of total biofuel output (IEA, 2018b).

Footprints serve as indicators of the pressure of a given activity or a product on the environment; they allow comparison with alternative activities or products delivering the same service and help us to understand the impacts of this pressure (Hoekstra \& Wiedmann, 2014). The footprint concept assumes that the resources are limited (McGlade et al., 2012) and allows comparison of aggregate footprint results with physical thresholds (Castellani \& Sala, 2012), such as planetary boundaries, thus helping to gauge the environmental pressure exerted on these boundaries. Thus, at the macro-scale, footprint assessment can help quantify aggregate resource uses and assess efficiency, equitability and security of resource uses (Hoekstra, 2017) within the range of a given system.

A combination of different environmental footprints is often referred to as a footprint family (Fang et al., 2014; Galli et al., 2012; Davy Vanham et al., 2019). While assessing one footprint helps to understand the pressure on one aspect of the environment, a combination or family of footprints can help comprehend tradeoffs between different resources. Land and water footprints refer to appropriation of land and freshwater resources, respectively, while a carbon footprint refers to the supply chain of GHG emissions (Hoekstra \& Wiedmann, 2014). The water footprint includes three components: a green component (consumption of precipitation water), a blue component (consumption 
of surface and groundwater), and a grey component (water required to assimilate pollution to accepted water quality standards) (Hoekstra et al., 2011). While the green water footprint component is often assumed insignificant assuming that green water would have been used by the natural vegetation and often is ignored when estimating the water footprints of biofuels e.g. IEA (2016c), the green water footprint can be considered to be important for at least two reasons. First, differences in evapotranspiration (i.e., green water footprint) between crop fields and fields under natural conditions can be significant during particular times of the year (Hoekstra et al., 2011), which can affect the run-off volumes, and hence can affect the availability of blue water in the area. Second, quantification of green water can support increasing water productivity in agriculture (Hoekstra, 2019) by selecting crops that can yield the same amount of benefit (e.g., in terms of energy output or monetary units) per unit of water consumed. In this thesis, the environmental footprint family refers to the ensemble of land, water, and carbon footprints, following the work of Hoekstra and Wiedmann (2014).

\subsection{Research objectives}

Research on sustainable transport does not currently capture the full environmental benefits and impacts of different strategy options (Zhao et al., 2020). To this day, many studies have looked at one individual footprint of transport fuels (Azadi et al., 2014; Gerbens-Leenes \& Hoekstra, 2011; Gerbens-Leenes et al., 2009b; Mathioudakis et al., 2017; Mehmeti et al., 2018; Su et al., 2015) with very few studies covering two (Gerbens-Leenes et al., 2014; Rulli et al., 2016; Yang et al., 2009) and only a limited number of studies covering more than two footprints (Mekonnen et al., 2018). Specifically, Gerbens-Leenes et al., (2009b) Su et al., (2015) Mathioudakis et al., (2017) and Mehmeti et al. (2018) focused on the water footprint analysis while Azadi et al., (2014) focused on the carbon footprint analysis per unit of transport fuel production. Gerbens-Leenes \& Hoekstra, (2011) translated water footprint per unit of energy to water footprint per unit of traveled distance in different modes of transport. In contrast, Yang et al., (2009) Gerbens-Leenes et al., (2014) and Rulli et al., (2016) assessed both water and land footprints per unit of transport fuel production. Recently, Mekonnen et al., (2018) estimated water, land and energy footprints of bioethanol production in the USA and Brazil.

A systematic assessment and comparison of land, water and carbon footprints of alternative transport fuels is missing from the literature. Such a study is essential to understanding carbon footprint reduction and associated land and water tradeoffs as we transition to wide-scale use of alternative fuels. Moreover, studies to date have looked at footprints per gross biofuel output, but production of biofuels requires energy inputs in the production supply chain. Footprints per gross fuel output do not capture footprints of energy used as inputs. It is useful, however, to assess footprints per unit of net alternative transport fuels to comprehend a more accurate picture (in terms of land and water uses) of alternative transport fuels supplied to society.

The overarching objective of this research is to contribute to the discourse concerning energy transition to low-carbon technologies in the transport sector in order to meet 
climate targets while considering the land and water implications of alternative fuels. Specifically, I aim to (a) calculate the land, water and carbon footprints of conventional vs second generation biofuels per unit of net output to estimate the scale of emission reductions per unit of energy and the scale of land and water resources required as a tradeoff; and (b) estimate the global biofuel production potential under different sustainability criteria. Three guiding research questions are:

1. What are the land, water, and carbon footprints of conventional and advanced biofuels per unit of net energy output using different feedstock types and what is the environmental footprint of renewable electricity and hydrogen?

2. What choice of transport fuel reduces the carbon footprint the most with the least land and water requirements?

3. How much of the present-day use of oil products in the transport sector can be potentially replaced with biofuels and what are implications for GHG emissions and appropriation of land and water?

The first question is addressed by means of calculating the environmental footprint family of: conventional bioethanol, biodiesel and bioelectricity per main food crops (Chapter 2); fossil fuels, electricity from solar photovoltaic (PV), and hydrogen generated using solar PV electricity (Chapter 3); second generation lignocellulosic bioethanol from maize and wheat residue generated in 27 countries of the European Union (Chapter 4), and the second generation lignocellulosic bioethanol from 123 crop residues generated in 192 countries and 20 territories (Chapter 5). In Chapters 2 and 3, the environmental footprints are calculated using global averages. In contrast, Chapters 4 and 5 utilize region and country specific data to yield more representative environmental footprint families for given geographic areas.

The second question is addressed in Chapter 3, where environmental footprints of different energy sources (i.e., electricity, hydrogen, fossil fuels, and biofuels) are compared per unit of distance using the actual fuel efficiency of cars utilizing different fuels/electricity. This way, differences in efficiency of use of various fuels/electricity are also captured. For example, when compared side-by-side a unit of energy in the form of electricity is utilized in electric cars with higher efficiency than utilization of the same unit of energy in the form of fossil fuels or biofuels in conventional cars.

The third question is addressed in Chapters 2, 4 and 5. In Chapter 2 the third research question is answered in reverse order, i.e., can we replace a given amount of oil products with bioenergy and at what land and water cost? Specifically, the feasibility of replacing the current energy mix with a bioenergy mix (bioelectricity, heat and conventional biofuels) from five main food crops in two different energy scenarios is appraised. In Chapter 4, the focus is narrowed to the European Union, and analyzes the region's second generation bioethanol production potential from wheat straw and maize stover under certain sustainability constraints and gauged against the region's present-day use of oil products in the transport sector. Associated emission savings and the land and water costs of bioethanol produced in the region are also determined. Building on analysis conducted 
in Chapter 4, the analysis in Chapter 5 extends to cover the global second generation bioethanol production potential from all major crop residues with and without sustainability constraints in land management, comparing how much of the present-day uses of oil products in the transport sector can be replaced and what this means in terms of emissions savings and land and water costs.

\subsection{Structure of the research}

Conceptual visualization of this thesis is presented in Fig. 1.1. Conclusions and future research directions are presented in Chapter 6.

Fig. 1.1. Conceptual diagram of this thesis.

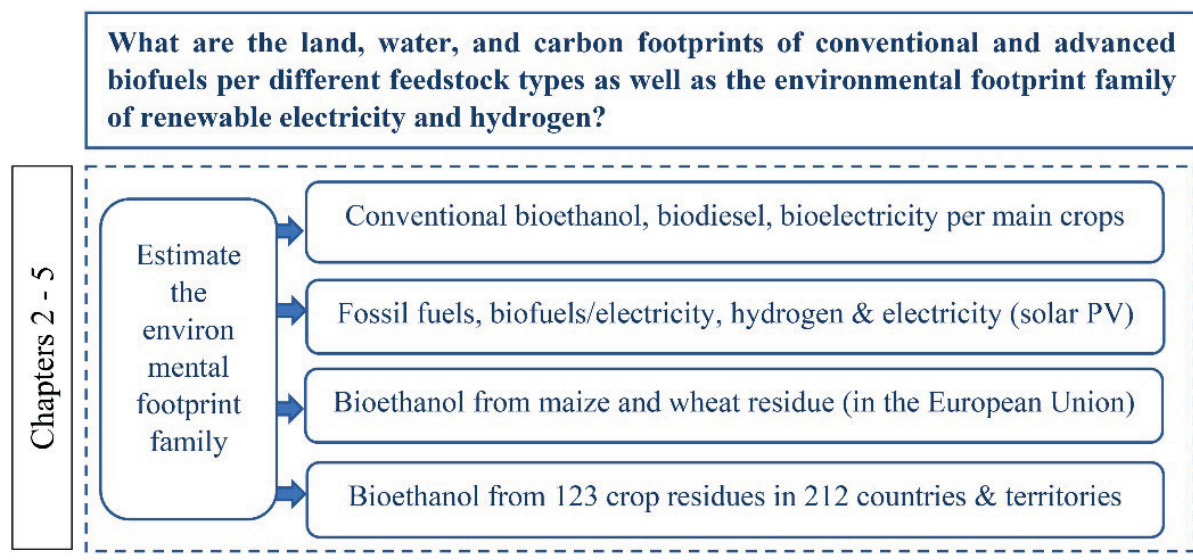

What choice of transport fuel reduces the carbon footprint the most with the least land and water requirements?

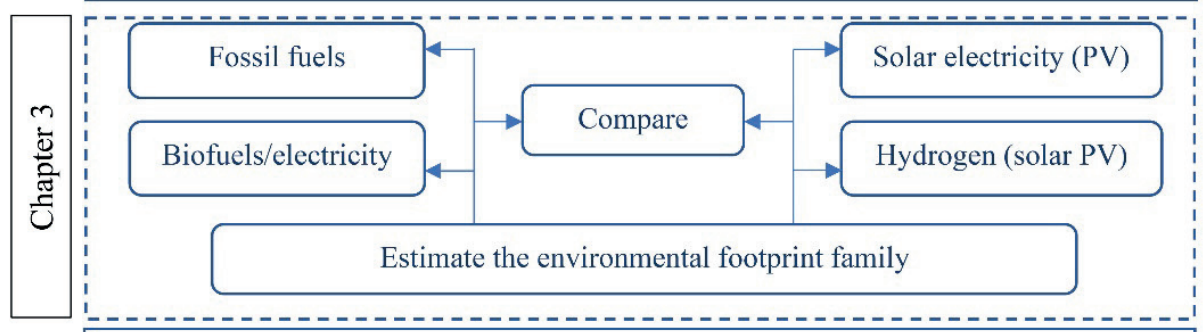

How much of the present-day oil product use in the transport sector can be potentially replaced with biofuels and what are implications for GHG emissions, and appropriation of land and water?

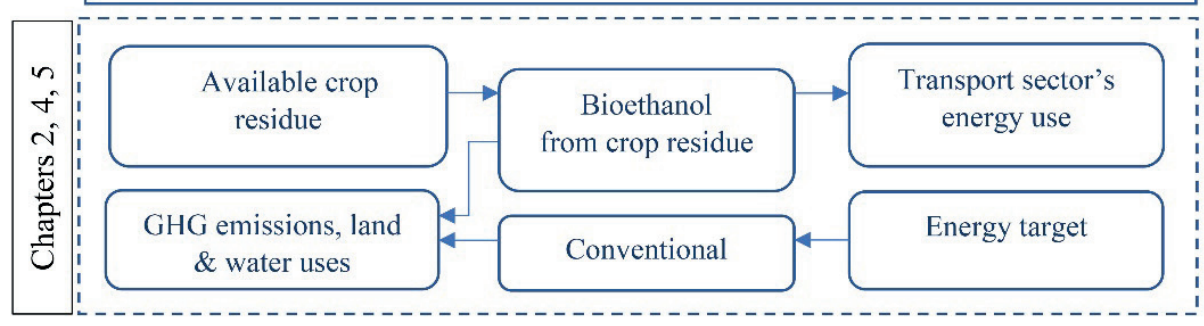




\title{
2. Land, Water and Carbon Footprints of Circular Bioenergy Production Systems ${ }^{1}$
}

\begin{abstract}
Renewable energy sources can help combat climate change but knowing the land, water and carbon implications of different renewable energy production mixes becomes a key. This paper systematically applies land, water and carbon footprint accounting methods to calculate resource appropriation and $\mathrm{CO}_{2}$ eq GHG emissions of two energy scenarios. The ' $100 \%$ scenario' is meant as a thinking exercise and assumes a complete transition towards bioenergy, mostly as bioelectricity and some first-generation biofuel. The 'SDS-bio scenario' is inspired by IEA's sustainable development scenario and assumes a $9.8 \%$ share of bioenergy in the final mix, with a high share of first-generation biofuel. Energy inputs into production are calculated by differentiating inputs into fuel versus electricity and exclude fossil fuels used for non-energy purposes. Results suggest that both scenarios can lead to emission savings, but at a high cost of land and water resources. A $100 \%$ shift to bioenergy is not possible from water and land perspectives. The SDS-bio scenario, when using the most efficient feedstocks (sugar beet and sugarcane), would still require $11-14 \%$ of the global arable land and a water flow equivalent to $18-25 \%$ of the current water footprint of humanity. In comparative terms, using sugar or starchy crops to produce bioenergy results in smaller footprints than using oil-bearing crops. Regardless of the choice of crop, converting the biomass to combined heat and power results in smaller land, water and carbon footprints per unit of energy than when converting to electricity alone or liquid biofuel.
\end{abstract}

\subsection{Introduction}

Global energy demand is rising: total final energy consumption has increased twofold since 1973, reaching 9,425 million tonnes of oil equivalent (Mtoe) in 2014 (IEA, 2016b). Electricity consumption has increased 3.9 times during this period, which is faster than consumption of other energy sources (natural gas, oil, coal). The increase in energy demand is driven by population growth, industrialization and urbanization (Johansson et al., 2012). Per capita energy use in 2014 (1921 kg of oil equivalent) was 35\% higher than in 1973 (1418 kg of oil equivalent) (WB, 2017). The largest increase in regional energy consumption occurred in the Middle East, $5.1 \%$ of the final global energy consumption in 2014 versus $0.7 \%$ in 1973 (IEA, 2016b).

Most of current human energy requirements are satisfied using fossil fuels, which are harmful to the environment. The most imminent dangers stemming from the energy sector are the emission of greenhouse gases (GHGs), air pollution, and water stress (IEA, 2015b). The emission of GHGs is a global issue and perhaps the most concerning. The energy sector contributes about two thirds of all anthropogenic GHG emissions (IEA, 2015b). According to the Intergovernmental Panel on Climate Change (IPCC), these

\footnotetext{
${ }^{1}$ This chapter has been published as:

Holmatov, B., Hoekstra, A. Y., and Krol, M.S. (2019). Land, water and carbon footprints of circular bioenergy production systems, Renewable and Sustainable Energy Reviews, 111:224-235. 
anthropogenic GHG emissions may have contributed between 0.5 and 1.3 degree Celsius increase to the global mean surface warming from 1951 to 2010 (Pachauri et al., 2014).

Renewable energy is increasingly viewed as a prominent part of the solutions to mitigate climate change (Edenhofer et al., 2011; IEA, 2015b; Wuester et al., 2015). Renewable energy is defined as energy from biological, geophysical or solar sources that is naturally replenished faster or at the rate equal to its use (Edenhofer et al., 2011). The feasibility and efficiency of different renewable energy depend on the availability, conversion efficiency and utilization rate of required natural resources. The resource appropriation of the major renewable energy sources, i.e., biomass, solar photovoltaics (PV), solar thermal, hydro, wind, ocean, and geothermal (Edenhofer et al., 2011; Turner, 1999) are far from equal and require foreknowledge of their appropriateness for particular sites or aims.

Globally, a sizable fraction of final energy consumption is already generated from renewable sources such as bioenergy (IEA, 2016b) and many countries have formed national plans to transition towards renewable energy generation in the near future. The term bioenergy implies that energy is produced from materials of biological origin without counting materials embedded in geological formations and turned into fossil sources (FAO, 2006). In 2005, 43 countries had national renewable energy targets, while the number had increased to 164 countries by 2015. Moreover, 59 countries had national renewable transport energy targets in 2015 (IRENA, 2016b). The fast transition towards renewable energy urges us to understand the implications of energy decisions on natural resources appropriation and sustainability of natural resources use.

A practical method for quantifying and comparing human pressure on the environment is assessing a "footprint" of a particular product or a human activity. Footprints serve as "indicators of human pressure on the environment" that help to understand environmental changes and impacts resulting from this pressure (Hoekstra \& Wiedmann, 2014). The common footprints are the land footprint (LF), water footprint (WF) and carbon footprint (CF). The LF is originally part of the "ecological footprint" that measures land required to satisfy consumption and for assimilating waste discharge of a defined population (Rees \& Wackernagel, 1996), but commonly only the land requirement to satisfy consumption is referred to as the LF (Hoekstra \& Wiedmann, 2014; Steen-Olsen et al., 2012; Weinzettel et al., 2013). The WF measures direct and indirect freshwater appropriation of a product, sector or community and consists of three components: the blue WF (consumption of surface water and groundwater), the green WF (consumption of rainwater) and the grey WF (the water demand to assimilate pollutants) (Hoekstra et al., 2011). The CF is defined as total carbon dioxide emissions measured in mass units ( $\mathrm{kg}$, tonnes, etc.) that are produced over the life of a product or directly and indirectly produced by an activity (Wiedmann \& Minx, 2008), but usually includes other GHG emissions in terms of carbon dioxide equivalents as well (Čuček et al., 2015; Hoekstra \& Wiedmann, 2014).

Generally, studies to this day focus on a single footprint of energy, with very few studies covering two footprints and, to our knowledge, none covering more than two. The three footprints together, the "footprint family", allows comprehensive monitoring of the various pressures on the environment (Fang et al., 2014; Galli et al., 2012) Footprint assessments help evaluate the sustainability of an activity or a product. Sustainability of 
activities depends on footprint characteristics such as size, timing and location relative to local thresholds or the overall planet's carrying capacity (Hoekstra \& Wiedmann, 2014).

Many studies have looked specifically at the WF of particular energy types at various scales (Gerbens-Leenes et al., 2012; Gerbens-Leenes \& Hoekstra, 2011; Gerbens-Leenes et al., 2009a; Gerbens-Leenes et al., 2009b; Hogeboom et al., 2018; Liu et al., 2015; Mehmeti et al., 2018; Mekonnen et al., 2015; Mekonnen et al., 2016; Mekonnen \& Hoekstra, 2012; Munoz Castillo et al., 2017; Okadera et al., 2014; Pacetti et al., 2015; Su et al., 2015) or at the CF of a particular energy (Azadi et al., 2014; de Wild-Scholten, 2013; Zhang \& Xu, 2015). Fewer studies focused on assessing a combination of LF and WF of particular energy carriers (Gerbens-Leenes et al., 2014; Rulli et al., 2016; Yang et al., 2009) or combination of CF and WF (Mekonnen et al., 2016; Miller \& Carriveau, 2017). No study has looked at the scale of water and land resources necessary to meet the global energy demand produced from renewable energy sources while estimating associated GHG emissions. This is important, however, given the clear evidence that some forms of renewable energy, notably bioenergy, come along with a large need for land and water (Gerbens-Leenes et al., 2009b; Mekonnen et al., 2015). To fill this gap, this study systematically assesses the LF, WF and CF of two circular bioenergy production scenarios, assuming different ratios of bioenergy in the final energy mix. Here, circular means that the bioenergy production system is self-sustaining and produces excess energy to compensate the input requirements for production.

\subsection{Methods}

\subsubsection{Fuel composition of two bioenergy production scenarios}

Two bioenergy production scenarios are considered (Table 2.1). The $100 \%$ scenario is a complete shift to bioenergy. The SDS-bio scenario is adapted from the sustainable development scenario (SDS) of the International Energy Agency (IEA), with a 9.77\% bioenergy share in the final consumed energy mix (IEA, 2017c).

Table 2.1. Shares of biofuel, heat and bioelectricity in the two scenarios.

\begin{tabular}{|c|c|c|c|c|}
\hline & Electricity & Fuel & Heat & Total \\
\cline { 2 - 5 } & \multicolumn{4}{|c|}{$100 \%$ scenario } \\
\hline Exajoules & 316.1 & 47.1 & 11.4 & 374.6 \\
\hline \% composition & 84.4 & 12.6 & 3.1 & 100 \\
\hline & \multicolumn{5}{|c|}{ SDS-bio scenario } \\
\hline Exajoules & 6.1 & 16.0 & 15.9 & 38.0 \\
\hline \% composition & 1.6 & 4.1 & 4.1 & 9.8 \\
\hline
\end{tabular}

$100 \%$ scenario. In this scenario, the share of heat in the total is assumed the same as the current global heat consumption, while the share of biofuel is taken equal to current fuel consumption in aviation, maritime and road freight transports combined. All the remaining energy consumption is assumed bioelectricity. The large share of bioelectricity is assumed because: (a) electricity consumption has increased the most since 1973 (IEA, 2016b); (b) demand is expected to further increase by 70\% towards 2035 (WWAP, 2014); and (c) its production is more water efficient than the production of biofuels (Gerbens- 
Leenes \& Hoekstra, 2011). The global bioenergy production equals the world's final consumption less non-energy uses (IEA, 2018c). Aviation energy demand is determined by adding final consumption of aviation gasoline and jet kerosene for 2014 (IEA, 2018d). Maritime and road freight energy demand are assumed as $5 \%$ and $18 \%$ of the total final oil products consumption, respectively, which correspond to the actual shares in 2015 (IEA, 2017b). Total final oil products consumption and total final heat consumption in 2014 are obtained from IEA (IEA, 2018c).

SDS-bio scenario. For this scenario the production quantity and ratios of bioelectricity, biofuel and heat are determined using IEA's SDS scenario for 2040 (IEA, 2017c). In IEA's SDS scenario, bioenergy will provide $9.77 \%$ of the total final consumption or 41.6 exajoules in 2040, an assumption that is based on the rationale and data described in detail by IEA (IEA, 2017c). Here, the shares of bioelectricity, fuel and heat from IEA's SDS scenario for 2040 are back calculated to align with the 2014 consumption in two steps. First, total bioenergy consumption in 2014 is assumed the same as in $2040-9.77 \%$. Second, the ratios of biofuel, bioelectricity and heat presented in the original SDS scenario are multiplied by their respective values for 2014. Specifically, in IEA's SDS scenario, $8.5 \%$ of power is generated using bioenergy (IEA, 2017c), thus $8.5 \%$ of total final consumed electricity in 2014 is assumed bioelectricity. Similarly, $14.5 \%$ of total final consumed energy in the transport sector in 2040 is in the form of biofuels (IEA, 2017c), thus $14.5 \%$ of total final consumed energy in the transport sector in 2014 is assumed biofuels. The difference between the total bioenergy and consumed bioelectricity plus biofuels in 2014 is assumed heat from bioenergy. The 2014 total energy consumption is obtained from the IEA (2018c).

\subsubsection{Energy calculations}

Bioelectricity or combined heat and power $(\mathrm{CHP})$ are generated using the entire feedstock biomass while only the economic yield fraction of the crop (the part of the crop that contains most of the sugar, starch or oil) can be converted to liquid biofuels. In both scenarios, we consider five alternative crops as feedstock for bioenergy, namely sugar beet, sugarcane, maize, soybean and rapeseed, which are selected for four reasons. First, sugar beet, sugarcane and maize are selected because they are the most utilized feedstock for bioethanol production (Abbasi \& Abbasi, 2010; Baeyens et al., 2015; Mussatto et al., 2010; Vohra et al., 2014) and second, they have the smallest WF per unit of bioelectricity production (Gerbens-Leenes et al., 2009b). Third, although the biodiesel can be produced from a range of oilseeds (Avinash et al., 2014; Salvi \& Panwar, 2012) as the number of known oil-bearing crops exceeds 350 (Koçar \& Civaş, 2013), rapeseed and soybean are the most commonly utilized crops for biodiesel production and fourth, their WFs are smaller compared to biodiesel from other crops (Gerbens-Leenes et al., 2009b).

Bioelectricity and heat. The energy embedded in crop biomass is converted to bioelectricity and heat through combustion in the CHP plant or only to bioelectricity in the power plant. In both cases, the heat energy content of crop biomass is calculated and converted to bioelectricity, or bioelectricity and heat, using conversion ratios presented below. The heat energy content of crop biomass is calculated by combining the higher heating value (HHV) of major plant ingredients, similar to the method employed by Gerbens-Leenes et al. (2009a); Gerbens-Leenes et al. (2009b): 


$$
E(c)=\left(H I(c) \times D M_{y}(c) \times \sum_{i=1}^{5} C_{i} \times A_{y, i}\right)+\left((1-H I)(c) \times D M_{r}(c) \times \sum_{i=1}^{5} C_{i} \times A_{r, i}\right)
$$

Where $\mathrm{E}(\mathrm{c})$ is the heat energy of crop $\mathrm{c}$ in $\mathrm{GJ}$ tonne $^{-1}, \mathrm{HI}(\mathrm{c})$ the harvest index of $\mathrm{c}, \mathrm{DM}$ the fraction of dry mass, A the content of ingredient $i$ in the DM $(\mathrm{g} / 100 \mathrm{~g})$ (see Table A10, Appendix A), $C$ the HHV value of ingredient $i$ in GJ tonne-1 (Table A11, Appendix A), $y$ the economic yield fraction, and $r$ the rest fraction.

Power plants achieve higher conversion efficiency of biomass to bioelectricity compared to CHP plants (BASIS, 2015). For the bioelectricity-only route, we use the highest reported operational conversion efficiency of $43 \%$ (Evans et al., 2010) achieved by combusting biomass in a power plant (Table 2.2). For the CHP route, the conversion efficiencies are assumed as $22 \%$ bioelectricity and $63 \%$ heat, corresponding to the average EU values in large CHP plants (>20 MW) operating on bio feedstock (BASIS, 2015).

Table 2.2. Biomass to bioelectricity and combined heat and bioelectricity conversion efficiencies used in this work. Biomass to CHP conversion efficiency is obtained from (BASIS, 2015) and biomass to bioelectricity efficiency from (Evans et al., 2010).

\begin{tabular}{|l|c|c|}
\hline & Power plant & CHP plant \\
\hline Bioelectricity & $43 \%$ & $22 \%$ \\
\hline Heat & -- & $63 \%$ \\
\hline Losses & $57 \%$ & $15 \%$ \\
\hline
\end{tabular}

Bioethanol. Bioethanol is produced from the sugar or starch in the economic yield fraction of crops. The bioethanol yield is calculated by the method described in Gerbens-Leenes $e t$ al. (Gerbens-Leenes et al., 2009b), assuming bioethanol's HHV of 29.7 GJ tonne-1:

$E_{\text {bioethanol }}(c)=D M_{y}(c) \times f_{\text {carbohydrate }}(c) \times f_{\text {bioethanol }} \times H H V_{\text {bioethanol }}$

Where $E_{\text {bioethanol }}(c)$ is the bioethanol output of crop c in GJ tonne ${ }^{-1}, f_{\text {carbohydrate }}(c)$ the fraction of carbohydrates in the DM of the economic yield $(\mathrm{g} / 100 \mathrm{~g})$ and $f_{\text {bioethanol }}$ the bioethanol yield per unit of carbohydrate that, consistent with (Gerbens-Leenes et al., $2009 \mathrm{~b}$ ), is assumed $0.51 \mathrm{~g} / \mathrm{g}$ for sugar (in the case of sugar beet and sugarcane) and 0.53 $\mathrm{g} / \mathrm{g}$ for starch (for maize).

Biodiesel. Biodiesel is produced from fat in the economic yield fraction of plants. The biodiesel yield is calculated following (Gerbens-Leenes et al., 2009b), assuming biodiesel's HHV of 37.7 GJ tonne ${ }^{-1}$ :

$E_{\text {biodiesel }}(c)=D M_{y}(c) \times f_{\text {fat }}(c) \times f_{\text {biodiesel }} \times H H V_{\text {biodiesel }}$

Where $E_{\text {biodiesel }}(c)$ is the biodiesel output of crop c in GJ tonne ${ }^{-1}, f_{\text {fat }}(c)$ the fraction of fats in the DM of the economic yield $(\mathrm{g} / 100 \mathrm{~g})$ and $f_{\text {biodiesel }}$ the amount of biodiesel yield per unit of fat that, consistent with (Gerbens-Leenes et al., 2009b), is assumed $1 \mathrm{~g} / \mathrm{g}$ of fat.

Global average crop yields (hectogram ha-1) for 2014 are obtained from the FAO (FAO, 2018). Gross biofuel output for crop c, calculated in steps 2 and 3 is converted to GJ ha-1 using the global average crop yields. Gross bioelectricity and heat output for crop c, calculated in step 1 is converted to $\mathrm{GJ}$ ha $^{-1}$ by first converting the global average crop yields to the global average biomass yields. The biomass yields are calculated by dividing the 
economic yields by the crop specific HI (Table A10, Appendix A). Next, the gross bioelectricity and heat outputs per unit weight of crop c biomass are multiplied by the global average biomass yield.

\subsubsection{Energy balance calculations}

Energy is required to produce energy. The amount and quality of energy input per unit of output can vary considerably, affected by factors such as the type of energy output, production scale, transport distances of required inputs and intermediate products, efficiency of production technology. Moreover, different feedstock crops have different cultivation requirements and biofuel production is very different from bioelectricity or combined heat-bioelectricity production.

The gross to net energy conversions and relevant methods and data sources are described in the supplementary materials (Appendix A). The net energy production is converted to the gross energy production using a circular feedback loop. The feedback loop differentiates input energy into bioelectricity versus biofuels. Moreover, the feedback loop treats the CHP route differently from the power-only route to account for different conversion efficiencies.

\subsubsection{Footprint calculations}

Land footprint. In each scenario, the total LF is calculated by summing land requirement for gross biofuel and gross bioelectricity production for a given crop c. The land requirement for gross biofuel production using a crop $\mathrm{c}$ is calculated as the sum of the gross biofuel requirements across the $\mathrm{CHP}$ and power-only routes for crop c (Table A9) divided by the gross biofuel output per hectare for crop c (Table 2.5). In contrast, the land requirement for gross bioelectricity production is calculated by dividing gross CHP production and gross bioelectricity production for a given crop c (Table A9) by their respective gross bioelectricity output per hectare (Table 2.5), and then adding them. That is because unlike the biofuel production, the bioelectricity production efficiency depends on the process and is different for the CHP route versus the power-only route.

Water footprint. Global average green, blue and grey WF of crops per unit of weight is obtained from Mekonnen and Hoekstra (2011) (Table A12, Appendix A) and converted to WF per hectare using the average crop yields per hectare for 2014 from FAO (2018). The average WF per hectare is then multiplied by the total land requirement for crop c in each of the two scenarios to obtain the total WF for a particular scenario.

Carbon footprint. Total bioenergy-related CFs of the two scenarios are calculated as the sum of $\mathrm{CO}_{2}$ eq emissions associated with: (1) nitrogen fertilizer production; (2) soil management; and (3) biomass and biofuel combustion as described below. All the GHG emissions are calculated according to IPCC's tier 1 method and the $\mathrm{CH}_{4}$ and $\mathrm{N}_{2} \mathrm{O}$ emissions from combustion are converted to $\mathrm{CO}_{2}$ eq using their 100 year global warming potentials of 28 and 265, respectively (Pachauri et al., 2014).

GHG emissions from fertilizer production (Fig. 2.1) refer to the cumulative emissions from producing nitrogen fertilizer - ammonium nitrate - that is obtained by neutralizing nitric acid with gaseous ammonia (EC, 2007). Ammonium nitrate can be used directly or combined with limestone, dolomite or calcium carbonate to produce other nitrogen 
fertilizers, i.e., urea ammonium nitrate, magnesium ammonium nitrate, ammonium sulphate nitrate and calcium ammonium nitrate, making it the most used fertilizer product in the Western Europe (EC, 2007).

Nitric acid and ammonia production are significant contributors to global GHG emissions (Eggleston et al., 2006). Ammonia is produced by synthesizing hydrogen gas $\left(\mathrm{H}_{2}\right)$ with nitrogen gas $\left(\mathrm{N}_{2}\right)$ (EC, 2007). While the atmosphere is a good source of $\mathrm{N}_{2}$, hydrogen production involves fossil fuels as feedstock. Hydrogen in ammonia production obtained through steam reforming accounts for $77 \%$ of the global capacity (EC, 2007). In this work, methane is assumed as the hydrogen feedstock.

\section{Methane $\left(\mathrm{CH}_{4}\right)$}

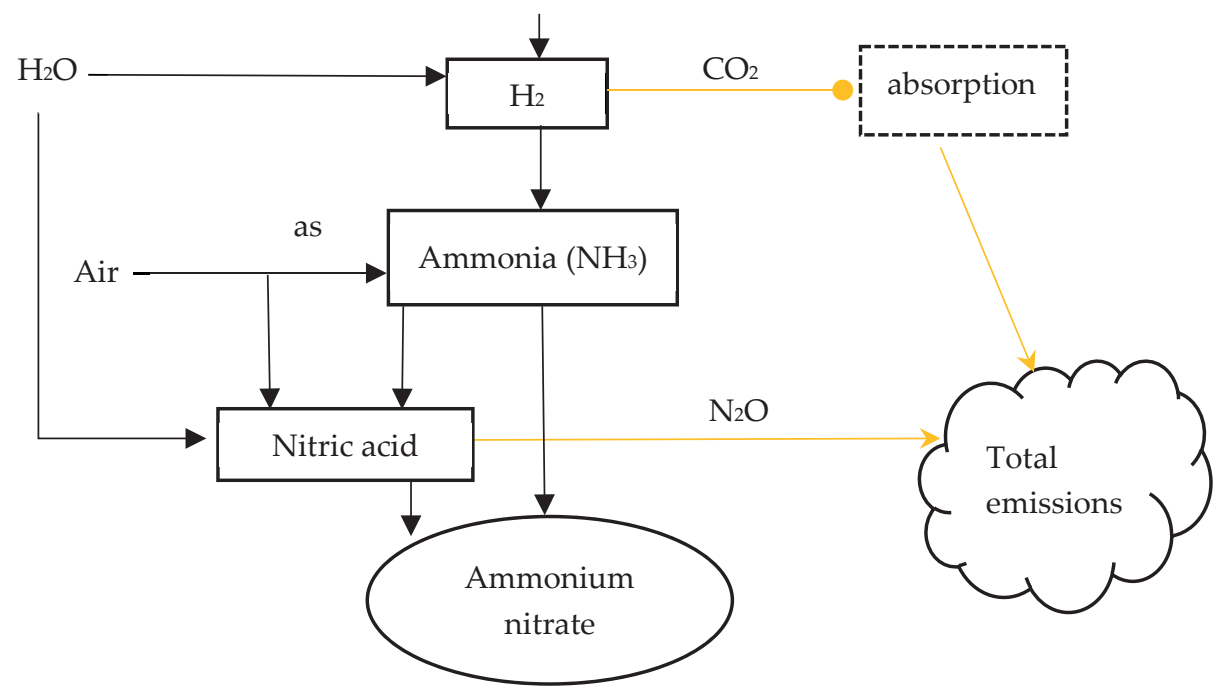

Fig. 2.1. Simplified representation of the GHG emissions from nitrogen fertilizer production.

The default values used to calculate $\mathrm{CO}_{2}$ emissions from ammonia production correspond to production processes in a modern European plant employing the conventional reforming of a natural gas (Eggleston et al., 2006). One adjustment is made for consistency with the previous assumptions, that is the total energy requirement per tonne of ammonia output excludes methane used as feedstock for hydrogen production (EC, 2007). The default $\mathrm{N}_{2} \mathrm{O}$ emission factor from nitric acid production corresponds to a production process in a high-pressure plant (Eggleston et al., 2006). The ratio of ammonia in ammonium nitrate fertilizer production and the ratio of nitric acid in fertilizer production are taken from Fossum (2014). The nitrogen fertilizer application requirements for specific crops are listed in the Appendix A (Table A3).

GHG emissions from managing soils refer to direct and indirect $\mathrm{N}_{2} \mathrm{O}$ emissions (Eggleston et al., 2006). The direct emissions are linked to nitrogen inputs to managed soils and include: $\mathrm{N}_{2} \mathrm{O}-\mathrm{N}$ emissions linked to the amount of synthetic nitrogen fertilizer applied for a specific crop, the annual amount of nitrogen in crop residues, and the amount of nitrogen in mineral soils that is mineralized based on soil carbon loss from organic matter caused by changes in land management and use. Crop-specific assumptions on soil organic 12 
carbon condition are summarized in Table 2.3. Utilized crop-specific soil characteristics are taken from the World Reference Base for Soil Resources (IUSS et al., 2006). The default IPCC factors are used to estimate $\mathrm{N}$ added to soils from crop residue, with two exceptions. First, the crop dry matter ratio is adopted from Gerbens-Leenes et al. (2009a); GerbensLeenes et al. (2009b) (Table A10, Appendix A). Second, crop yields are adjusted to account for seed requirements (i.e. economic yield minus seed requirements). For nitrogen additions, a default $\mathrm{N}_{2} \mathrm{O}-\mathrm{N}$ emission factor from IPCC (Eggleston et al., 2006) is used in this work.

Table 2.3. Assumptions for "current" soil organic carbon conditions in mineral soils.

\begin{tabular}{|c|c|c|c|c|}
\hline Crop & $\begin{array}{c}\text { Climate and soil for reference carbon } \\
\text { stock value }\end{array}$ & $\begin{array}{c}\text { Land-use } \\
\text { factor }\end{array}$ & $\begin{array}{c}\text { Management } \\
\text { factor }\end{array}$ & $\begin{array}{c}\text { Carbon input } \\
\text { values }\end{array}$ \\
\hline $\begin{array}{c}\text { Sugar } \\
\text { beet }\end{array}$ & cold temperate moist, HAC - Regosols & $\begin{array}{c}\text { long term } \\
\text { cultivation }\end{array}$ & reduced tillage & low \\
\hline $\begin{array}{c}\text { Sugarca } \\
\text { ne }\end{array}$ & tropical moist, HAC - Vertisols & $\begin{array}{c}\text { long term } \\
\text { cultivation }\end{array}$ & reduced tillage & low \\
\hline $\begin{array}{c}\text { Maize } \\
\text { Soybean }\end{array}$ & warm temp, moist HAC - Chernozem & $\begin{array}{c}\text { long term } \\
\text { cultivation }\end{array}$ & reduced tillage & medium \\
\hline $\begin{array}{c}\text { Rapesee } \\
\mathrm{d}\end{array}$ & cold temperate dry, HAC - Luvisol & $\begin{array}{c}\text { long term } \\
\text { cultivation }\end{array}$ & reduced tillage & low \\
\hline
\end{tabular}

${ }^{*} H A C$ refers to high activity clay.

The indirect emissions cover $\mathrm{N}_{2} \mathrm{O}-\mathrm{N}$ emissions from: the atmospheric deposition of nitrogen that is volatilized from managed soils and from leaching/runoff. Atmospheric deposition of volatilised nitrogen is linked to the synthetic fertilizer application for a specific crop multiplied by the fraction that is volatilised and the default emission factor (Eggleston et al., 2006). Similarly, emissions from leaching are linked to the synthetic fertilizer application for a specific crop, but extend to also cover nitrogen added annually to soils from crop residue, and annual nitrogen mineralized in mineral soils multiplied by the fraction of all added nitrogen that is lost to leaching and the default emission factor from leaching (Eggleston et al., 2006).

Emissions from combustion of biomass in stationary plants for bioelectricity production are calculated differently than emissions from combustion of biofuel in mobile sources. In this study, emissions from biomass and biofuel combustion include $\mathrm{CH}_{4}$ and $\mathrm{N}_{2} \mathrm{O}$ emissions only because consistent with the IPCC assumptions the $\mathrm{CO}_{2}$ emissions are assumed zero (Eggleston et al., 2006). Default emission factors for combustion of solid biomass in stationary sources are obtained from the IPCC (Eggleston et al., 2006). Emissions factors for combustion of biofuels in mobile sources depend on many factors, such as the type of transport, technology, etc. (Eggleston et al., 2006). In this study, emission factors for biodiesel and bioethanol combustion refer to emissions from medium and heavy duty trucks obtained from USEPA (2016). The emissions are converted from gram mile $\mathrm{e}^{-1}$ to $\mathrm{kg} \mathrm{ha}^{-1}$ based on the following assumptions and data: 5.8 miles gallon $^{-1}$ 
average fuel efficiency of class-8 trucks traveling at a speed of $55 \mathrm{mph}$ (Franzese, 2011), biofuel density from Table 2.4, HHVs of bioethanol and biodiesel of 29.7 and 37.7 GJ tonne${ }^{1}$ respectively, biofuel energy yield per unit of land from Table 2.6, and conversion of miles to $\mathrm{km}$ and US gallons to litres.

Table 2.4. Biofuel density conversion values.

\begin{tabular}{|c|c|c|c|}
\hline Biofuel & Value & Unit & Source \\
\hline Bioethanol & 0.7887 & $\mathrm{~kg} \mathrm{~L}^{-1}$ & RFA (2015) \\
\hline Biodiesel & 0.8424 & $\mathrm{~kg} \mathrm{~L}^{-1}$ & Alptekin \& Canakci (2008) \\
\hline
\end{tabular}

\subsection{Results and discussion}

\subsubsection{Energy outputs per unit of weight and per unit of area}

Energy outputs per tonne of feedstock do not differ between scenarios. Maize-based production yields most energy as bioelectricity, $\mathrm{CHP}$, and bioethanol per unit weight (Table 2.5). In contrast, sugar beet as a feedstock gives least bioelectricity or CHP, while sugarcane gives least bioethanol per unit weight. Rapeseed as a feedstock yields more biodiesel energy per unit of weight than soybean.

Table 2.5. Energy outputs in GJ tonne ${ }^{-1}$ specified per crop.

\begin{tabular}{|c|c|c|c|c|c|c|}
\hline \multirow{2}{*}{ Crop } & \multirow{2}{*}{ Accounting } & \multirow{2}{*}{ Electricity } & \multicolumn{2}{|c|}{$\mathrm{CHP}^{* *}$} & \multirow{2}{*}{ Bioethanol ${ }^{\mathrm{a}}$} & \multirow{2}{*}{ Biodiesel $^{\mathrm{a}}$} \\
\hline & & & Electricity & Heat & & \\
\hline \multirow{2}{*}{ Sugar beet } & Gross & 1.6 & 0.8 & 2.4 & 2.6 & -- \\
\hline & $\mathrm{Net}^{*}$ & 1.4 & 0.8 & 2.2 & 2.3 & -- \\
\hline \multirow{2}{*}{ Sugarcane } & Gross & 2.3 & 1.2 & 3.4 & 2.3 & - \\
\hline & Net & 2.1 & 1.1 & 3.2 & 2.1 & -- \\
\hline \multirow{2}{*}{ Maize } & Gross & 7.3 & 3.7 & 10.6 & 10.0 & -- \\
\hline & Net & 6.5 & 3.5 & 10.1 & 5.2 & -- \\
\hline \multirow{2}{*}{ Soybean } & Gross & 4.3 & 2.2 & 6.3 & -- & 6.2 \\
\hline & Net & 3.7 & 2.1 & 5.9 & -- & 2.6 \\
\hline \multirow{2}{*}{ Rapeseed } & Gross & 3.0 & 1.6 & 4.4 & -- & 11.7 \\
\hline & Net & 2.1 & 1.3 & 3.7 & -- & 6.6 \\
\hline
\end{tabular}

Notes: ${ }^{*}$ Net is gross minus input energy per tonne. ${ }^{* *}$ Feedstock is 1 tonne of biomass. ${ }^{\text {a }}$ Feedstock is 1 tonne of economic yield fraction.

Table 2.6 shows the energy output per hectare. Sugarcane is the most efficient feedstock for producing net bioethanol, bioelectricity and CHP per unit area while sugar beet comes second. Maize gives the least bioethanol per unit area, four times less than either sugar beet or sugarcane in net terms. The rapeseed-based production system generates the least bioelectricity and CHP output per unit area. The soybean-based production system generates the least biodiesel per unit area. 
Table 2.6. Energy outputs in GJ ha ${ }^{-1}$ specified per crop.

\begin{tabular}{|c|c|c|c|c|c|c|}
\hline \multirow{2}{*}{ Crop } & \multirow{2}{*}{ Accounting } & \multirow{2}{*}{ Electricity $^{* *}$} & \multicolumn{2}{|c|}{$\mathrm{CHP}^{* *}$} & \multirow{2}{*}{ Bioethanol $^{\text {a }}$} & \multirow{2}{*}{ Biodiesel $^{\mathrm{a}}$} \\
\hline & & & Electricity & Heat & & \\
\hline \multirow{2}{*}{ Sugar beet } & Gross & 147.2 & 75.3 & 215.7 & 157.3 & -- \\
\hline & $\mathrm{Net}^{*}$ & 126.2 & 69.9 & 200.1 & 139.6 & -- \\
\hline \multirow{2}{*}{ Sugarcane } & Gross & 261.2 & 133.6 & 382.7 & 157.3 & -- \\
\hline & Net & 239.8 & 128.1 & 366.8 & 142.0 & -- \\
\hline \multirow{2}{*}{ Maize } & Gross & 90.5 & 46.3 & 132.6 & 56.1 & -- \\
\hline & Net & 80.7 & 43.8 & 125.4 & 29.1 & -- \\
\hline \multirow{2}{*}{ Soybean } & Gross & 27.8 & 14.2 & 40.7 & -- & 15.8 \\
\hline & Net & 23.9 & 13.2 & 37.8 & -- & 6.5 \\
\hline \multirow{2}{*}{ Rapeseed } & Gross & 19.3 & 9.9 & 28.3 & - & 23.8 \\
\hline & Net & 13.3 & 8.3 & 23.8 & -- & 13.3 \\
\hline
\end{tabular}

Notes: ${ }^{*}$ Net is gross minus bioelectricity and biofuel inputs per hectare. ${ }^{* *}$ Feedstock is the total biomass. ${ }^{\text {a }}$ Feedstock is the economic yield fraction.

$\mathrm{CHP}$ generation yields the most total energy per unit of land and unit of weight (with the exception of rapeseed). Sugarcane, maize and soybean can produce more net energy as bioelectricity than biofuel per unit of land. Net bioelectricity output of a soybean-based production system yields over three times more energy than net biodiesel output per unit of land. Similarly, net bioelectricity output of a maize-based production system yields over twice more energy than net bioethanol output per unit of land. In contrast, sugar beet and rapeseed can produce more energy as biofuel than bioelectricity per unit of land.

\subsubsection{Energy return on investment for different crops and carriers}

The computed ratios of energy output per unit of energy input, referred to in literature as the Energy Return on Investment (EROI) (Hall et al., 2009), do not differ between the two scenarios. With the exception of the case of sugar beet, EROI is highest for CHP output followed by the bioelectricity output (Tables 2.7 and 2.8). For CHP and bioelectricity outputs, the sugarcane-based production system has the highest EROI, while the rapeseed-based production system has the lowest EROI. The EROI of using maize feedstock for CHP and bioelectricity output is also high, only slightly lower than the EROI of the sugarcane-based production system.

Table 2.7. Calculated EROI for bioelectricity and CHP production from different crops.

\begin{tabular}{|c|l|l|l|l|l|}
\hline & Sugar beet & Sugarcane & Maize & Soybean & Rapeseed \\
\hline Bioelectricity & 7.0 & 12.2 & 9.2 & 7.1 & 3.2 \\
\hline CHP & 13.9 & 24.1 & 18.2 & 14.0 & 6.3 \\
\hline
\end{tabular}

The EROI values for biofuels are lower than for bioelectricity (except for the sugar beet feedstock) and for CHP (Table 2.8). The EROIs of biofuels produced from sugar beet, sugarcane, maize, soybean and rapeseed feedstock are higher in this study than in most 
previous literature. Bioethanol from sugarcane has the highest overall EROI, followed by bioethanol from sugar beet. Biodiesel from soybean has the lowest EROI.

Table 2.8. EROI values of biofuel production utilizing different feedstock (without coproducts if specified) from the current study versus literature.

\begin{tabular}{|c|c|c|c|c|c|}
\hline \multirow{2}{*}{ Source } & \multicolumn{3}{|c|}{ Bioethanol } & \multicolumn{2}{|c|}{ Biodiesel } \\
\hline & Sugar beet & Sugarcane & Maize & Soybean & Rapeseed \\
\hline De Oliveira et al. (2005) & & 3.7 & 1.1 & & \\
\hline Pimentel \& Patzek (2005) * & & & 0.8 & 0.8 & \\
\hline Hill et al. (2006) & & & 1.3 & 1.9 & \\
\hline Smith et al. (2007) & & & & 1.7 & $2.2 \mathrm{c}$ \\
\hline Von Blottnitz \& Curran (2007) ** & 2.0 & 7.9 & 1.3 & & \\
\hline Boddey et al. (2008) & & 8.8 & & & \\
\hline Pimentel et al. (2009) * & & & 0.7 & 0.6 & \\
\hline Yee et al. (2009) & & & & & 1.4 \\
\hline Pereira and Ortega (2010) & & 8.2 & & & \\
\hline Chen and Chen (2011) & & & & & 0.9 \\
\hline Fore et al. (2011) * & & & & 1.3 & $1.2 \subseteq$ \\
\hline Nogueira (2011) & & & & 3.3 & \\
\hline Kraatz et al. (2013) $\underline{a}$ & & & 1.6 & & \\
\hline de Castro et al. (2014) $\underline{b}$ & & 5.0 & 1.3 & & 1.5 \\
\hline Brondani et al. (2015) & & & & 1.0 & \\
\hline van Duren et al. (2015) & & & & & $<2.2$ \\
\hline Donke et al. (2017) & & 11.5 & 6.9 & & \\
\hline Current study & 8.9 & 10.3 & 2.1 & 1.7 & 2.3 \\
\hline
\end{tabular}

Notes: ${ }^{*}$ Not originally reported but calculated by dividing energy outputs by the inputs. ${ }^{* *}$ Results from a review.

Not originally reported but calculated by dividing the HHV of ethanol by the energy inputs, excluding energy

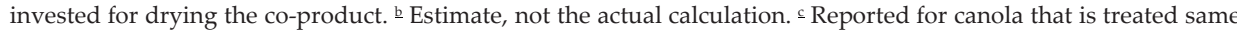
as rapeseed.

Within the dynamic loop, the share of output circulated to sustain production varies between energy scenarios, between biofuel and bioelectricity, and between crops (Fig. 2.2). In the $100 \%$ scenario, $32-41 \%$ of gross biofuel output is used as input for bioelectricity production, the precise fraction depending on the feedstock, while in the SDS-bio scenario that fraction is $4-13 \%$ percent. Regardless of the scenario, oil-bearing crops consume a larger share of the output to sustain production. 
$\beta_{1} Y$

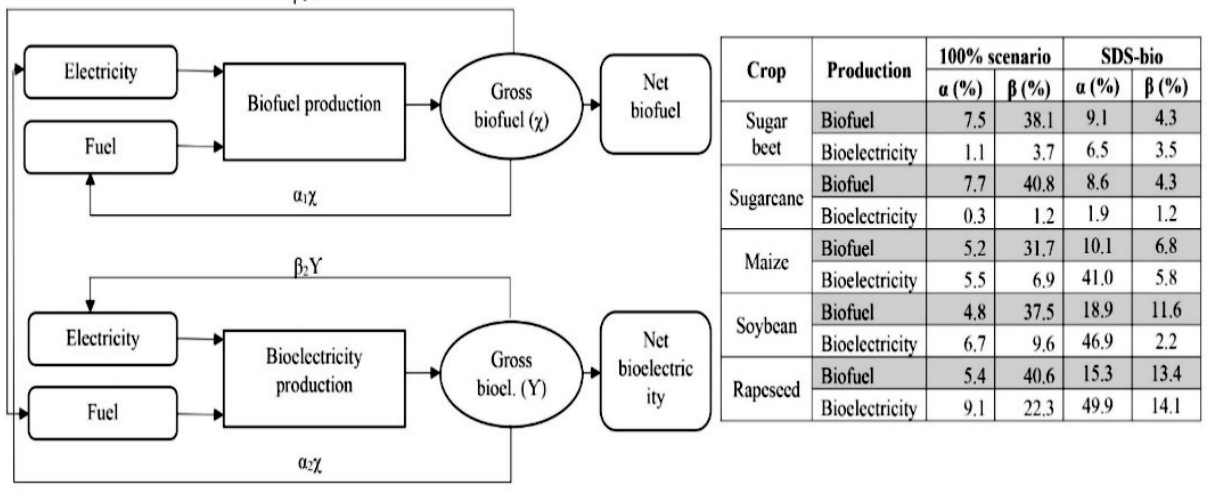

Fig. 2.2. Schematic representation of the dynamic feedback loop and percentages of gross biofuel and bioelectricity outputs used as inputs.

\subsubsection{LF of the bioenergy production scenarios}

The LF per GJ of bioenergy varies between feedstocks and is different for biofuel, bioelectricity and CHP. For sugarcane, maize and soybean, the LF of producing a GJ of biofuel is larger than the LF per GJ of bioelectricity or CHP output (Table 2.9). The LF of a GJ of biodiesel output using soybean feedstock, for example, is over three times larger than the LF of producing a GJ of bioelectricity and seven time larger than the LF of producing a GJ of CHP. Only in case of sugar beet and rapeseed the LF of producing a GJ of biofuel is smaller than producing a GJ of bioelectricity, albeit slightly.

Table 2.9. The LF per unit of net energy $\left(\mathrm{m}^{2} \mathrm{GJ}^{-1}\right)$.

\begin{tabular}{|c|c|c|c|c|}
\hline Crops & Bioelectricity & CHP & Bioethanol & Biodiesel \\
\hline Sugar beet & 79 & 37 & 72 & -- \\
\hline Sugarcane & 42 & 20 & 70 & -- \\
\hline Maize & 124 & 59 & 344 & -- \\
\hline Soybean & 418 & 196 & -- & 1544 \\
\hline Rapeseed & 754 & 311 & -- & 750 \\
\hline
\end{tabular}

In the $100 \%$ scenario, the LF of energy production is larger than the global land area currently utilized in arable agriculture (14.2 million $\mathrm{km}^{2}$ in 2014) (FAO, 2019) regardless of choice of feedstock. Meeting global energy consumption with bioenergy using sugarcane feedstock is the least land intensive, requiring 18.3 million $\mathrm{km}^{2}$ or $129 \%$ of the current global arable land, while using sugar beet feedstock requires 28.3 million $\mathrm{km}^{2}$ or $200 \%$ of the global arable land (Fig. 2.3). The LF of maize-based bioenergy production in the $100 \%$ scenario is 53.7 million $\mathrm{km}^{2}$ or $379 \%$ of the global arable land, whereas using soybean would require $1337 \%$ and rapeseed $1970 \%$ of the global arable land. In the $100 \%$ scenario, bioelectricity generation accounts for more than two thirds of the LF regardless of the feedstock choice. 


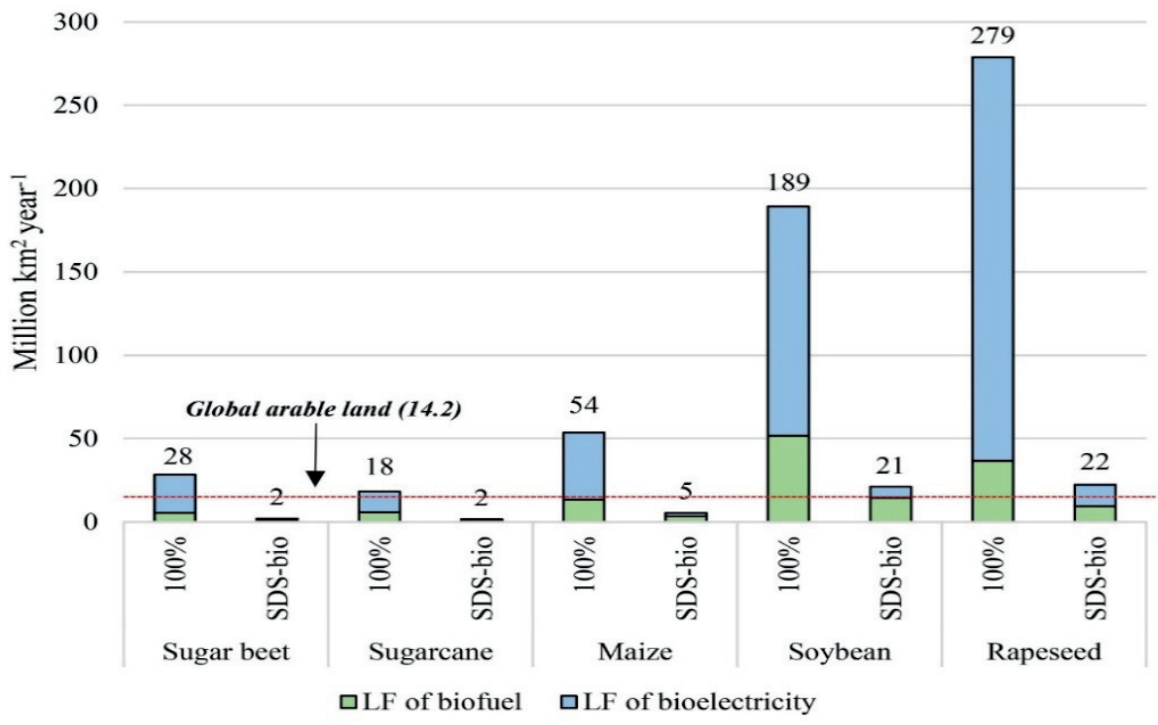

Fig. 2.3. LFs of the two global bioenergy production scenarios based on different feedstock specified by type of energy (biofuel or bioelectricity).

In the SDS-bio scenario, the LF varies widely between feedstock crops as well. Using sugarcane would require the least land, namely $11.4 \%$ of the current global arable land, using sugar beet would take $14.2 \%$, maize $37.9 \%$, soybean $149 \%$ and rapeseed $157.6 \%$. In the SDS-bio scenario, biofuel generation is responsible for a larger LF compared to bioelectricity generation in all cases except in a rapeseed-based production system.

\subsubsection{WF of the bioenergy production scenarios}

The WF per GJ of biofuel is larger than the WF per GJ of bioelectricity or CHP when sugarcane, maize or soybean is used as feedstock (Table 2.10). The least amount of water is needed to produce a GJ as CHP output using sugar beet or sugarcane feedstock. In contrast, producing a GJ of biodiesel from soybean requires the most amount of water, that is 14 times more than required to produce a GJ of bioethanol using sugar beet.

Table 2.10. The WF per unit of net energy $\left(\mathrm{m}^{3} \mathrm{GJ}^{-1}\right)$.

\begin{tabular}{|c|c|c|c|c|}
\hline Crops & Bioelectricity & CHP & Bioethanol & Biodiesel \\
\hline Sugar beet & 63 & 29 & 57 & -- \\
\hline Sugarcane & 59 & 29 & 100 & -- \\
\hline Maize & 85 & 40 & 235 & -- \\
\hline Soybean & 227 & 106 & -- & 838 \\
\hline Rapeseed & 348 & 144 & -- & 346 \\
\hline
\end{tabular}

In the $100 \%$ scenario, using any feedstock, the water requirement would be so large that it would even exceed the current WF of humanity of 9,087 $\mathrm{km}^{3} \mathrm{y}^{-1}$ (Hoekstra \& Mekonnen, 2012). Meeting the global energy consumption using sugar beet feedstock would have the smallest WF, i.e. $22,600 \mathrm{~km}^{3} \mathrm{y}^{-1}$ (with a blue WF component of 4,400 $\mathrm{km}^{3} \mathrm{y}^{-1}$ ). In this best- 
case, water use in the world would increase by a factor 3.5. Using rapeseed, the WF would be $128,600 \mathrm{~km}^{3} \mathrm{y}^{-1}$ (blue WF of 13,100 $\mathrm{km}^{3} \mathrm{y}^{-1}$ ) (Fig. 2.4), thus multiplying current water use in the world by a factor 15 . In relative terms, the WFs of sugar/starch-bearing feedstock are smaller and comparable whereas the WF of the oil-bearing feedstock are larger and mutually comparable.

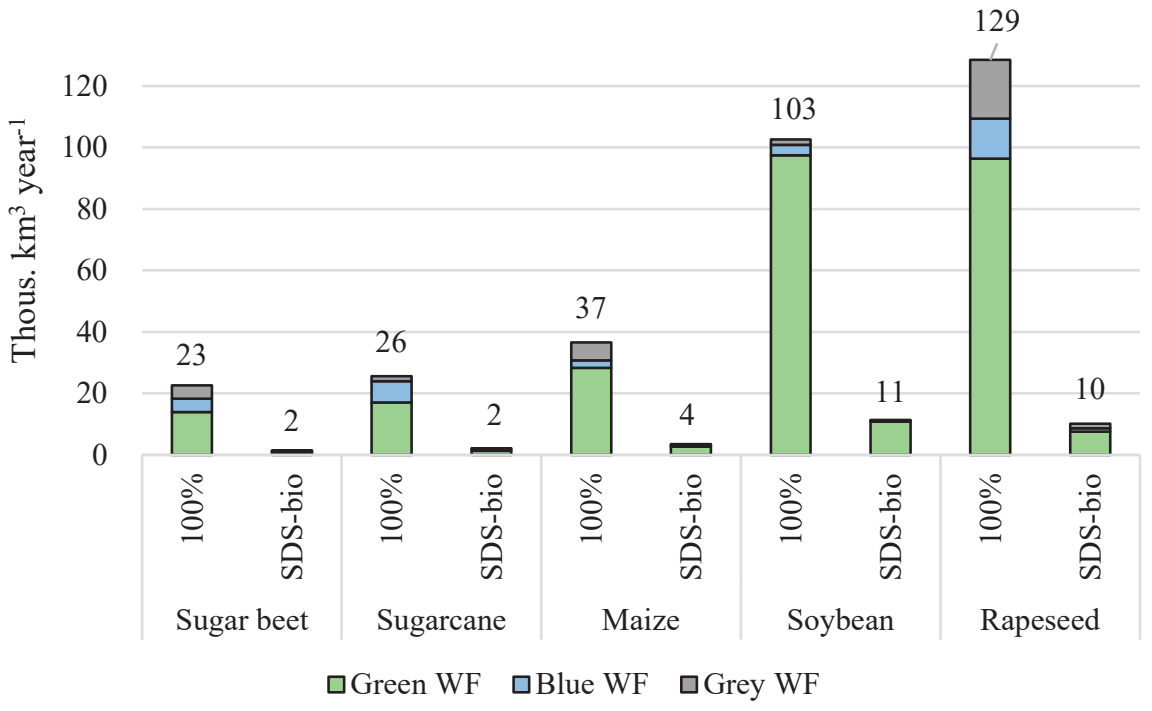

Fig. 2.4. WF of two global bioenergy production scenarios based on different feedstock and specified by WF component (green, blue, grey).

In the SDS-bio scenario, the WF of the bioenergy produced using sugar/starch-bearing feedstock is smaller than the current WF of humanity but larger in case of oil-bearing feedstock systems (Fig. 2.4 and 2.5). Using any of the five feedstocks will require WF larger than the current global WF of all industries. The global WF of industries, which includes the WF of energy production, is currently estimated at $400 \mathrm{~km}^{3} \mathrm{y}^{-1}$ (Hoekstra \& Mekonnen, 2012). The blue WF of the current energy production varies between studies due to methodological differences from $48 \mathrm{~km}^{3} \mathrm{y}^{-1}$ for global power and primary energy production (IEA, 2016c) to $217 \mathrm{~km}^{3} \mathrm{y}^{-1}$ for power and heat production alone (Mekonnen et al., 2015). In this study, the most water-efficient production system, based on sugar beet, has a WF of 1,600 km $\mathrm{km}^{3} \mathrm{y}^{-1}$ (with a blue WF of $310 \mathrm{~km}^{3} \mathrm{y}^{-1}$ ), the next most water-efficient production system, based on sugarcane, has a WF of 2,290 $\mathrm{km}^{3} \mathrm{y}^{-1}$ (with a blue WF of 620 $\mathrm{km}^{3} \mathrm{y}^{-1}$ ), and the least water-efficient production, based on soybean, has a WF of 11,450 $\mathrm{km}^{3} \mathrm{y}^{-1}$ (with a blue WF of $370 \mathrm{~km}^{3} \mathrm{y}^{-1}$ ). 


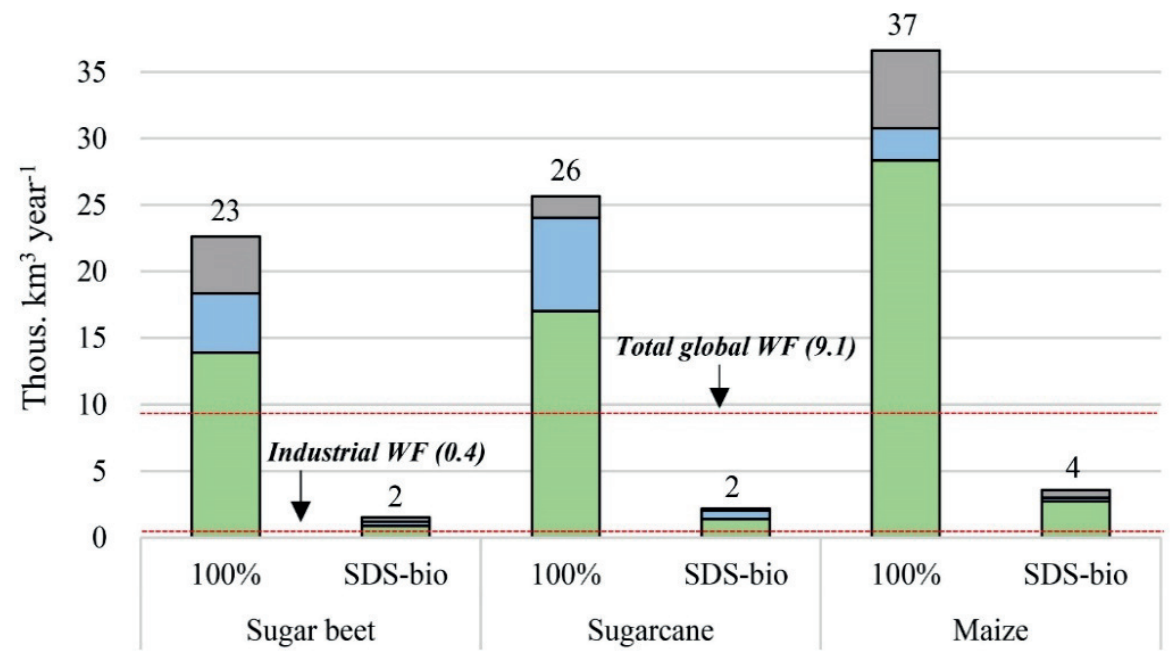

$\square$ Green WF $\quad$ B Blue WF $\quad$ Grey WF

Fig. 2.5. WF of two global bioenergy production scenarios based on three most water efficient feedstock and specified by WF component (green, blue, grey).

Green WF makes up the largest share of the total WF in both scenarios, in the range of $62 \%$ to $95 \%$, regardless of the choice of feedstock. The contribution of blue and grey WF varies between crops. While the blue WF is larger than the grey WF in case of sugar beet, sugarcane and soybean, the grey WF is larger than blue WF in case of maize and rapeseed. The share of blue WF in a total WF ranges from 3.3\% in the soybean-based system to $27 \%$ in the sugarcane-based system.

\subsubsection{CF of the bioenergy production scenarios}

The CF per unit of biofuel energy from sugarcane, maize and soybean is larger than the CF per unit of bioelectricity or CHP derived energy (Table 2.11). Sugar beet and rapeseed feedstock are the exceptions, where the CF per unit of biofuel energy is smaller than the CF per unit of bioelectricity. The rapeseed-based production system has the largest CF per unit of bioelectricity and CHP derived energy, while the soybean-based production system has the largest CF per unit of biofuel energy.

Table 2.11. The CF per unit of net energy ( $\left.\mathrm{kg} \mathrm{CO}_{2} \mathrm{eq} \mathrm{GJ}^{-1}\right)$.

\begin{tabular}{|c|c|c|c|c|}
\hline Crops & Bioelectricity & CHP & Bioethanol & Biodiesel \\
\hline Sugar beet & 22 & 10 & 19 & -- \\
\hline Sugarcane & 11 & 5 & 14 & -- \\
\hline Maize & 32 & 15 & 82 & -- \\
\hline Soybean & 40 & 19 & -- & 130 \\
\hline Rapeseed & 94 & 39 & -- & 87 \\
\hline
\end{tabular}

In the $100 \%$ scenario, the CF of energy production from all feedstocks except rapeseed is smaller than the actual $32.4 \mathrm{Gt}$ of $\mathrm{CO}_{2} \mathrm{eq}$ (IEA, 2016a) emitted in 2014 from fuel 
combustion. The sugarcane-based production system has the smallest CF, 4.4 Gt of GHGs per annum, while, at the other extreme, the rapeseed-based production system has a CF of $34.4 \mathrm{Gt}$ of $\mathrm{CO}_{2}$ eq emissions (Fig. 2.6), that exceeds current emissions level by $6 \%$. The $\mathrm{CF}$ values are $7.8 \mathrm{Gt}$ for sugar beet, $13.7 \mathrm{Gt}$ for maize, and 17.7 Gt for soybean-based production systems. The CF of bioelectricity generation is responsible for a much larger $\mathrm{CF}$ than the biofuel generation.

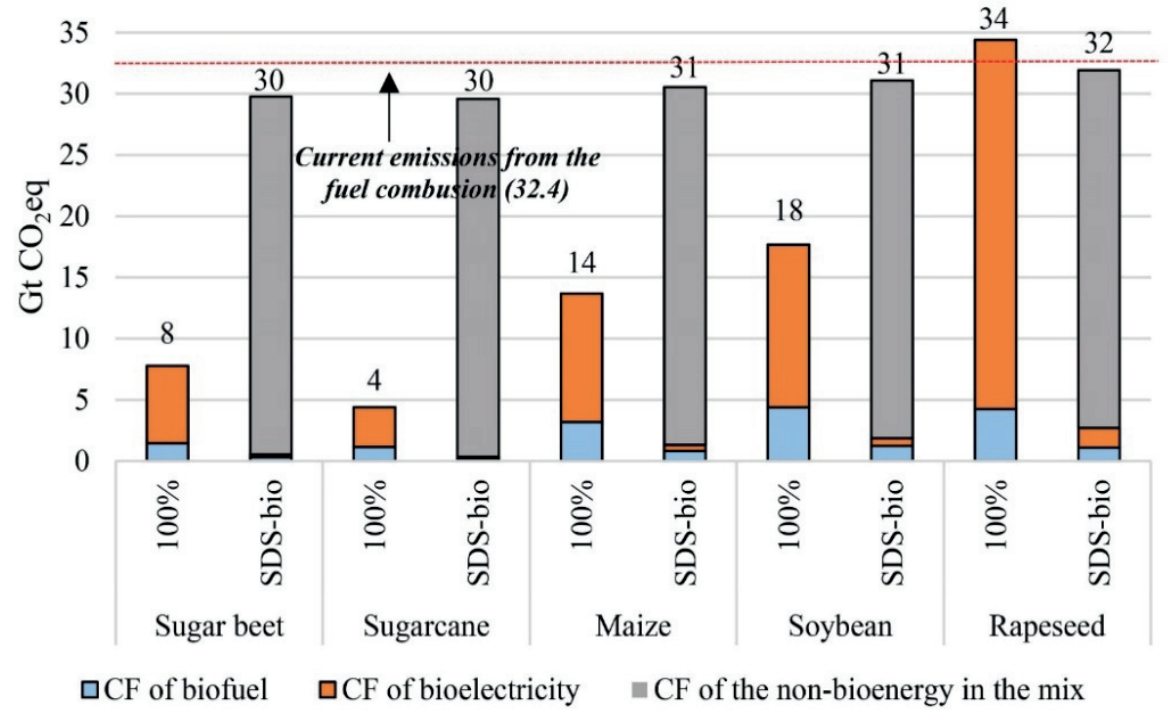

Fig. 2.6. CF of two global bioenergy production scenarios based on different feedstock and specified by energy type.

In the $100 \%$ scenario, the circular bioenergy production system leads to emission savings in all but rapeseed based feedstock systems (Table 2.12). The largest savings occur when sugarcane is used as feedstock (86.5\%). In contrast, using rapeseed as feedstock leads to $6.2 \%$ higher emissions compared to the current emission from fuel combustion.

Table 2.12. Emissions savings in two bioenergy scenarios for alternative feedstock.

\begin{tabular}{|l|c|c|}
\hline \multirow{2}{*}{ Feedstock } & $\mathbf{1 0 0} \%$ scenario & SDS-bio scenario \\
\hline Sugar beet & $76.0 \%$ & $8.1 \%$ \\
\hline Sugarcane & $86.5 \%$ & $8.7 \%$ \\
\hline Maize & $57.8 \%$ & $5.7 \%$ \\
\hline Soybean & $45.4 \%$ & $4.0 \%$ \\
\hline Rapeseed & $-6.2 \%$ & $1.4 \%$ \\
\hline
\end{tabular}

Resource trade-offs in the 100\% scenario are presented in Fig. 2.7 and Fig. 2.8. Emission savings in the $100 \%$ scenario come at the expense of large LFs and WFs. Using rapeseed will emit higher emissions than current emissions while requiring large land and water 
footprints. For each of the five considered feedstocks, the LF will exceed the global arable land (Fig. 2.7). The WF will exceed the current total WF of humanity irrespective the choice of feedstock (Fig. 2.8).

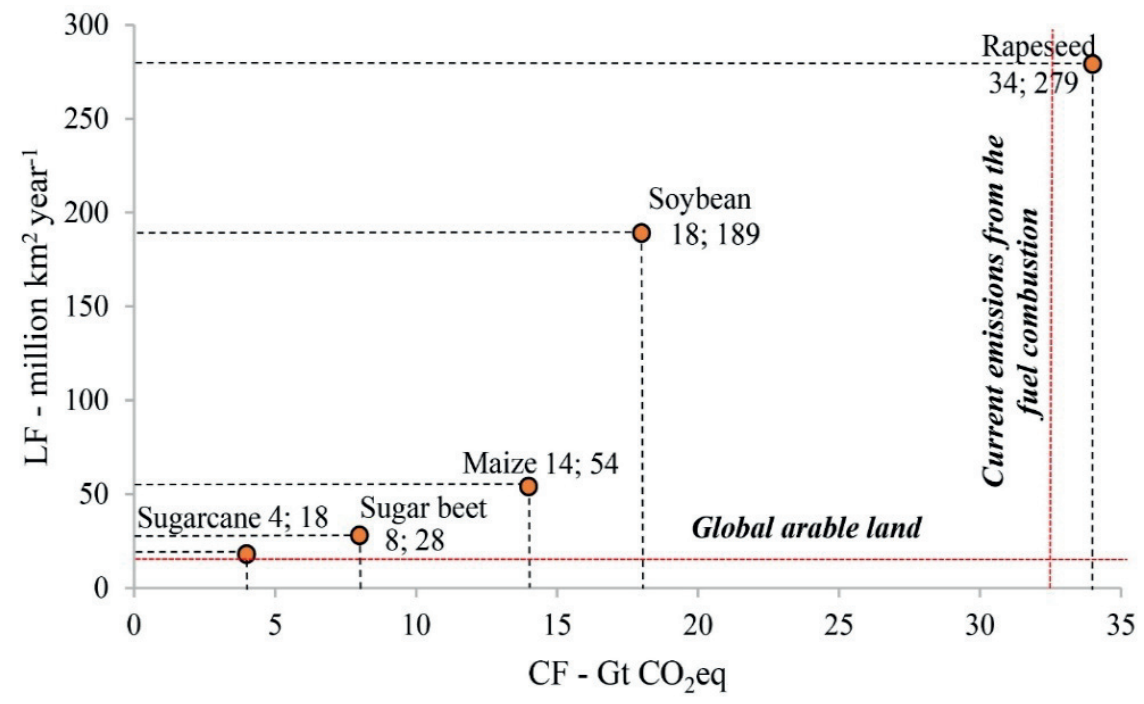

Fig. 2.7. The LF versus CF of bioenergy production in the $100 \%$ scenario for alternative feedstock.

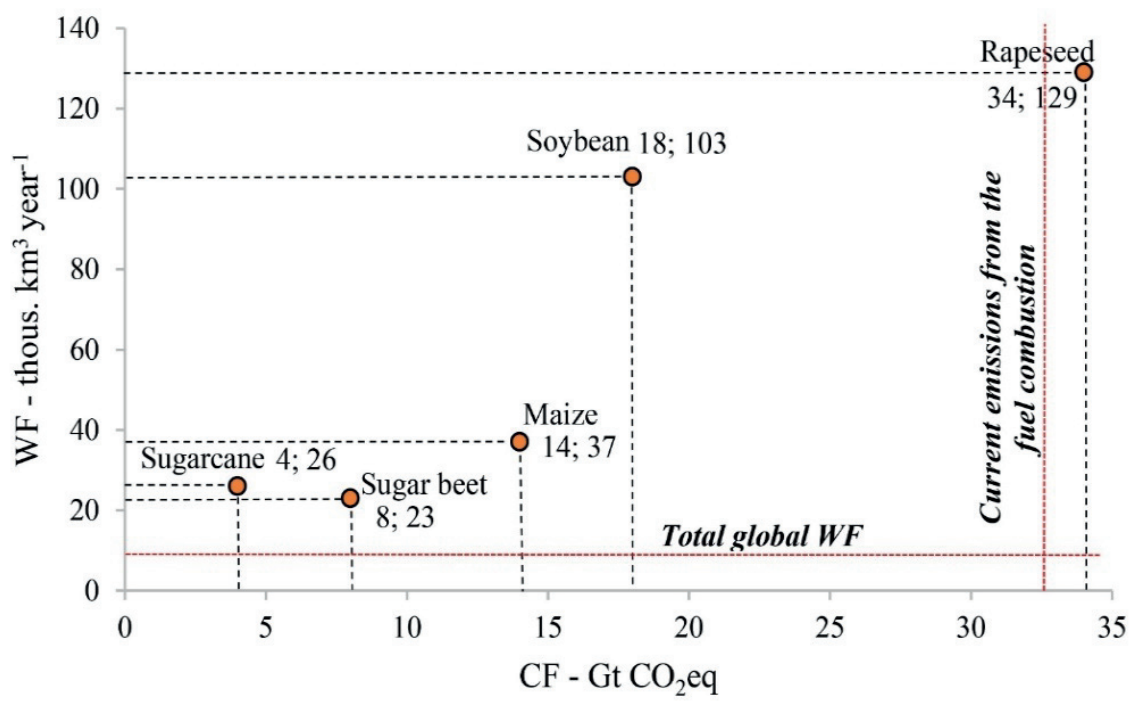

Fig. 2.8. The WF versus CF of bioenergy production in the $100 \%$ scenario for alternative feedstock.

In the SDS-bio scenario, the CF of bioenergy ranges from $0.35 \mathrm{Gt}$ of $\mathrm{CO}_{2} \mathrm{eq}$ in the case of sugarcane as feedstock to $2.70 \mathrm{Gt}$ in the case of rapeseed. The share of biofuel-related CF 
is larger than the bioelectricity-related CF in all production systems except for the rapeseed-based production systems.

Emission savings in the SDS-bio scenario compared to the actual emissions are all positive (Table 2.12). The emission savings range from $8.7 \%$ for when sugarcane is used as feedstock to $8.1 \%$ for sugar beet, $5.7 \%$ for maize, $4.0 \%$ for soybean and $1.4 \%$ for rapeseed.

In both scenarios, emissions from soil management are responsible for the largest share of GHG emissions (Table 2.13). More specifically, direct emissions from soil management make up over half of total emissions for producing bioelectricity and biofuels, except in a sugarcane-based production system. Combustion of biomass in stationary sources leads to higher GHG emissions than combustion of biofuel in mobile sources.

Table 2.13. Contribution of different stages to the total CF $\left(\mathrm{kg} \mathrm{CO}_{2} \mathrm{eq} \mathrm{ha} \mathrm{h}^{-1}\right)$.

\begin{tabular}{|l|c|c|c|c|c|c|c|}
\hline & Fertilizer prod. & \multicolumn{2}{|c|}{ Soil management } & \multicolumn{2}{c|}{ Combustion } & \multicolumn{2}{c|}{ Total } \\
\cline { 2 - 8 } & Nitrogen & Direct & Indirect & Bioel. & Biofuel & Bioel. & Biofuel \\
\hline Sugar beet & 257 & 1479 & 383 & 650 & 534 & 2769 & 2653 \\
\hline Sugarcane & 102 & 1080 & 263 & 1154 & 534 & 2599 & 1979 \\
\hline Maize & 348 & 1456 & 395 & 400 & 191 & 2600 & 2391 \\
\hline Soybean & 11 & 679 & 155 & 123 & 1 & 967 & 845 \\
\hline Rapeseed & 216 & 735 & 207 & 85 & 2 & 1244 & 1160 \\
\hline
\end{tabular}

\subsubsection{Resource hungry bioenergy: a forbidden fruit?}

Meeting the global energy demand using first-generation bioenergy is not feasible. Limited water and land availability prevents a large-scale application of first-generation bioenergy. The dilemma of water for food and feed versus water for energy has received a lot of attention (de Fraiture et al., 2008; Fritsche et al., 2010; HLPE, 2013; Pimentel et al., 2009; Rulli et al., 2016), and this study's results show that first-generation bioenergy is incredibly thirsty.

The fact that WFs per unit of bioenergy are much larger than for fossil energy has been shown extensively (Gerbens-Leenes et al., 2009a), (Dominguez-Faus et al., 2009). Recent studies looked at the water footprints of generating electricity and heat from a range of sources and found that the WF of bioenergy (using firewood as the feedstock) are degrees of magnitude larger than WFs of electricity and heat generated from other renewables such as wind, solar PV, geothermal (Mekonnen et al., 2015) and also the fossil sources such as coal, oil, natural gas, and nuclear (Mekonnen et al., 2016). The gross WF per unit of biofuels calculated in this study are similar to those reported by Gerbens-Leenes et al. (2012).

Although fewer studies looked at the LF of bioenergy, there is a concern that bioenergy can lead to undesired land use changes and transformations (Croezen et al., 2010; Eisentraut, 2010; Fargione et al., 2008; HLPE, 2013; UNCTAD, 2015). This study demonstrates that the LF of first-generation bioenergy is as prohibitive as the WF. The land requirement in the $100 \%$ scenario will exceed cropland area currently available. Especially in the case of rainfed agriculture, land becomes a key factor determining the 
impact of biofuels (WWAP, 2014). Moreover, continuous use of land for monoculture cultivation can have negative impact on the regional hydrologic cycle (Bernacchi, 2013), aggravating any existing water issues.

The LFs per unit of bioenergy calculated in this study are similar to the results of previous studies. Rulli et al. (2016) reported a weighted mean of $90 \mathrm{~m}^{2}$ of land required per GJ of bioethanol that is close to the LF per unit of net bioethanol from sugar beet $\left(72 \mathrm{~m}^{2} \mathrm{GJ}^{-1}\right)$ and sugarcane $\left(70 \mathrm{~m}^{2} \mathrm{GJ}^{-1}\right)$ calculated in this study. Gerbens-Leenes et al. (2014) reported the LF of algae-based biofuel in the range of $20-200 \mathrm{~m}^{2} \mathrm{GJ}^{-1}$ that is also similar to the LF of bioethanol production calculated in this study.

Next-generation biofuels may help reduce the WF (WWAP, 2014) but can lead to a range of complications as well. Mathioudakis et al. (2017) calculated WFs of second-generation bioenergy from crop residues and reports that bioethanol from sugar beet pulp requires only $6.3 \mathrm{~m}^{3} \mathrm{GJ}^{-1}$ and from sugarcane bagasse $18.3 \mathrm{~m}^{3} \mathrm{GJ}^{-1}$. Gerbens-Leenes et al. (2014) calculated WFs of third-generation biofuels from microalgae and reports that the net WF ranges from 8 to $193 \mathrm{~m}^{3} \mathrm{GJ}^{-1}$. These results suggest that the WF of next-generation bioenergy can be reduced several times compared to the WF of the first-generation bioenergy. However, there are factors that prevent large-scale application of nextgeneration bioenergy. The most evident factors are: agricultural residues already serve important functions (Eisentraut, 2010) (e.g. preventing erosion, maintaining soil structure and mineral composition, animal feed), the processes are costly (UNCTAD, 2015), energy yields are lower compared to first-generation (Gupta \& Verma, 2015), and resultant biofuels are of inferior quality (in case of pyrolysis oil from agricultural residue) (GerbensLeenes \& Hoekstra, 2013). In addition, the use of trees for energy purposes may be inefficient and can accelerate climate change (Searchinger et al., 2018). Also the WF of wood-based bioethanol at $97 \mathrm{~m}^{3} \mathrm{GJ}^{-1}$ (Schyns et al., 2017) exceeds the WF of first-generation bioethanol from sugar beet and is similar to that of bioethanol from sugarcane. The advanced biofuels are being produced on a commercial scale only after 2013 (UNCTAD, 2015) and their commercial production is still negligible (Eisentraut, 2010; Rulli et al., 2016; WWAP, 2014). Investments on advanced biofuels in 2015 were an order of magnitude smaller than investment levels on conventional (first-generation) biofuels in 2006 or 2007 (IRENA, 2016a). So it is likely that first-generation biofuels will dominate until 2030s (Aditiya et al., 2016; Murphy et al., 2011).

\subsubsection{Biofuel or bioelectricity?}

The choice of crops should be aligned with the type of energy demand as the efficiency of converting crops to bioelectricity versus biofuel varies. Specifically, the LF, WF and CF of producing biofuel from sugar beet and rapeseed are smaller than the respective footprints of producing bioelectricity. In contrast, the LF, WF and CF of producing bioelectricity from sugarcane, maize and soybean are smaller than the respective footprints of producing biofuels. For all crops, the smallest LF, WF and CF per unit of net bioenergy is through the CHP generation.

In terms of the smallest footprints per unit of bioelectricity and biofuels, sugarcane and sugar beet are the winners among the considered feedstock crops. From the LF and CF perspectives, sugarcane is the most efficient feedstock to produce $\mathrm{CHP}$, bioelectricity or bioethanol. From the WF perspective, sugarcane is the most efficient feedstock to produce 
bioelectricity but sugar beet is the most efficient feedstock to produce bioethanol. In contrast, soybean and rapeseed are the least efficient feedstock from the LF, WF and CF perspectives, meaning that biodiesel production is much less efficient than bioethanol production.

\subsubsection{Bioenergy - can lead to emission savings.}

Findings of this paper suggest that bioenergy can lead to significant emission savings. In the $100 \%$ scenario the GHG emissions can be reduced compared to the actual emissions in all cases except using rapeseed feedstock. The level of GHG emission reductions varies caused by many causal factors such as the supply chain efficiency, feedstock, and land use change linked emissions (Eisentraut, 2010; IEA, 2011, 2017a). Depending on the choice of causal factors the GHG emission potential of bioenergy have been reported both positive and negative compared to that of fossil fuels (Cherubini et al., 2009; de Vries et al., 2010; HLPE, 2013).

In the SDS-bio scenario the GHG emission savings also largely depend on the choice of feedstock. The emissions in this case can be reduced compared to the actual emissions regardless of the choice of feedstock.

\subsubsection{Bioenergy - emission savings versus water and land costs}

From the climate perspective, the GHG reductions calculated in this study are significant but at the large cost of land and water. In the $100 \%$ scenario, the emission reduction potential of all but rapeseed based system can help maintain the emissions under or within the desired range of 18-25 Gt COzeq per annum (Hoekstra \& Wiedmann, 2014). However, these significant emission reductions would require more water than current total global water use and more land than the current global arable land area. This is impossible given the already high levels of current land and water scarcity. An energy scenario at the expense of a steep increase in land and water use as identified in this study cannot be a sustainable solution to reducing GHG emissions.

The emission savings in the SDS-bio scenario also come at a high cost in terms of increased land and water use. The water requirements of the SDS-bio scenario will exceed the current industrial WF by at least several folds and result in an increase of the current WF of humanity by at least $17.6 \%$ (in case of a sugar beet based system). The LF in the SDSbio scenario will require at least $11.4 \%$ of the arable land (in case of a sugarcane based system).

\subsubsection{EROI - an inappropriate metric?}

A key finding from this work is that an EROI factor is not an appropriate metric to identify energy production efficiencies when different energy output types are considered. EROI captures the ratio of final energy to initial energy, whereby a smaller initial energy input compared to the output generates a large EROI. Rapeseed for example has an EROI of 3.2 in case of bioelectricity production and an EROI of 2.3 in case of biodiesel production. This is because the input energy for bioelectricity production is almost two times smaller than the input energy for biodiesel production. However, despite a higher EROI for the bioelectricity production route, the bioelectricity yield (13.3 GJ ha-1) is similar to the biodiesel yield (13.3 GJ ha $\left.{ }^{-1}\right)$ in net accounting terms. 
EROI is a useful measure when the energy inputs are similar, but can lead to misinterpretation when different production processes, hence inputs are expected. Producing a similar energy type from different feedstocks entails comparatively similar energy inputs, which is different for the case of producing different energy types from the same or different feedstock. In the latter case, the processes are different and energy inputs for different processes may differ greatly. The EROI measure then cannot reveal the net energy gain for different fuel production routes and can instead lead to misinterpretation of results. An EROI metric should be used with caution when different energy output types are involved.

\subsubsection{Uncertainties and sensitivities}

To understand the effects of input data on the results, we assessed the sensitivity to four different input parameters: crop yield, transport distance, biomass to electricity conversion efficiency and fertilizer use. Specifically, crop yields can vary between countries, so we tested the effect of a $20 \%$ yield increase. Regarding the transport distance, this study assumed $50 \mathrm{~km}$ for both crop delivery and fuel delivery. However, the IEA report (O'Connor, 2013) has assumed as much as $100 \mathrm{~km}$ for the biomass transport distance, which we used for the sensitivity analysis. Similarly, the highest biomass to electricity conversion efficiency of $43 \%$ was assumed in this study, while an average efficiency is $27 \%$ (Evans et al., 2010), which we used for the sensitivity analysis. Lastly, the fertilizer input was decreased by $10 \%$ to understand its effect on the study results.

Tables 2.14 - 2.15 present the effects of changing the input parameters on the study results for the SDS-bio and the $100 \%$ scenarios, respectively. In both cases, increasing yield can reduce land, water and carbon footprints regardless of feedstock. Decreasing biomass to electricity conversion efficiency leads to the largest increase in land, water and carbon footprints in the $100 \%$ scenario regardless of feedstock. In the SDS-bio scenario, the changes due to decreasing conversion efficiency lead to larger footprints in systems based on maize, soybean and rapeseed. In both scenarios, reducing fertilizer input leads to larger CF reduction compared to the LF and WF reductions. Increasing the transport distance increases all footprints but the magnitude of increases varies both between scenarios and feedstocks. 
Table 2.14. Changes in study results due to changing input parameters in the SDS-bio scenario.

\begin{tabular}{|c|c|c|c|c|c|c|}
\hline \multicolumn{2}{|l|}{ Parameter } & Sugar beet & Sugarcane & Maize & Soybean & Rapeseed \\
\hline \multirow{3}{*}{ 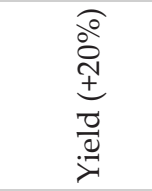 } & $\mathrm{LF}$ & $-17.5 \%$ & $-17.4 \%$ & $-19.0 \%$ & $-23.0 \%$ & $-25.7 \%$ \\
\hline & WF & $-17.5 \%$ & $-17 \%$ & $-19.0 \%$ & $-22.6 \%$ & $-25.6 \%$ \\
\hline & CF & $-11.9 \%$ & $-9.7 \%$ & $-15.8 \%$ & $-20.1 \%$ & $-24 \%$ \\
\hline \multirow{3}{*}{ 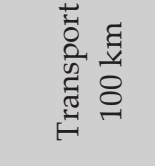 } & LF & $+6.9 \%$ & $+9.2 \%$ & $+4 \%$ & $+7.5 \%$ & $+5.8 \%$ \\
\hline & WF & $+6.9 \%$ & $+9.2 \%$ & $+4 \%$ & $+7.5 \%$ & $+5.8 \%$ \\
\hline & $\mathrm{CF}$ & $+6.8 \%$ & $+8.5 \%$ & $+3.9 \%$ & $+7.4 \%$ & $+5.8 \%$ \\
\hline \multirow{3}{*}{ 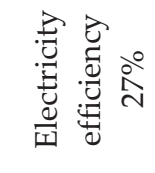 } & LF & $+3.5 \%$ & $+1.2 \%$ & $+17.4 \%$ & $+17.2 \%$ & $+38.9 \%$ \\
\hline & WF & $+3.5 \%$ & $+1.2 \%$ & $+17.4 \%$ & $+17.2 \%$ & $+38.9 \%$ \\
\hline & $\mathrm{CF}$ & $+3.6 \%$ & $+1.5 \%$ & $+18.2 \%$ & $+18.5 \%$ & $+39.8 \%$ \\
\hline \multirow{3}{*}{ 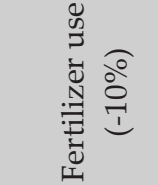 } & LF & $-0.4 \%$ & $-0.2 \%$ & $-1.1 \%$ & $-0.6 \%$ & $-3 \%$ \\
\hline & WF & $-0.4 \%$ & $-0.2 \%$ & $-1.1 \%$ & $-0.6 \%$ & $-3 \%$ \\
\hline & $\mathrm{CF}$ & $-3.8 \%$ & $-1.9 \%$ & $-6.1 \%$ & $-1 \%$ & $-9.3 \%$ \\
\hline
\end{tabular}

Table 2.15. Percent changes in study results due to changing the input parameters in the $100 \%$ scenario.

\begin{tabular}{|c|c|c|c|c|c|c|}
\hline \multicolumn{2}{|l|}{ Parameter } & Sugar beet & Sugarcane & Maize & Soybean & Rapeseed \\
\hline \multirow{3}{*}{ 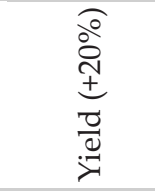 } & $\mathrm{LF}$ & $-17.4 \%$ & $-17.3 \%$ & $-18.6 \%$ & $-19.6 \%$ & $-22.7 \%$ \\
\hline & WF & $-17.4 \%$ & $-16.9 \%$ & $-18.5 \%$ & $-19.2 \%$ & $-22.6 \%$ \\
\hline & CF & $-11.7 \%$ & $-8.7 \%$ & $-14.8 \%$ & $-15.8 \%$ & $-20.5 \%$ \\
\hline \multirow{3}{*}{ 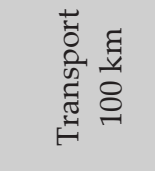 } & $\mathrm{LF}$ & $+9.4 \%$ & $+17.0 \%$ & $+5.9 \%$ & $+11.7 \%$ & $+6.4 \%$ \\
\hline & WF & $+9.4 \%$ & $+17.0 \%$ & $+5.9 \%$ & $+11.7 \%$ & $+6.4 \%$ \\
\hline & CF & $+9.1 \%$ & $+14.0 \%$ & $+5.6 \%$ & $+10.8 \%$ & $+6.2 \%$ \\
\hline \multirow{3}{*}{ 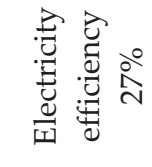 } & LF & $+50.5 \%$ & $+40.5 \%$ & $+54.0 \%$ & $+56.6 \%$ & $+93.1 \%$ \\
\hline & WF & $+50.5 \%$ & $+40.5 \%$ & $+54.0 \%$ & $+56.6 \%$ & $+93.1 \%$ \\
\hline & $\mathrm{CF}$ & $+51.0 \%$ & $+43.8 \%$ & $+55.1 \%$ & $+58.4 \%$ & $+93.8 \%$ \\
\hline \multirow{3}{*}{ 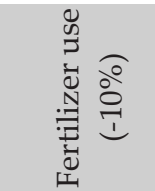 } & LF & $-0.4 \%$ & $-0.2 \%$ & $-1.0 \%$ & $-0.6 \%$ & $-2.2 \%$ \\
\hline & WF & $-0.4 \%$ & $-0.2 \%$ & $-1.0 \%$ & $-0.6 \%$ & $-2.2 \%$ \\
\hline & $\mathrm{CF}$ & $-3.7 \%$ & $-1.7 \%$ & $-5.9 \%$ & $-0.9 \%$ & $-8.3 \%$ \\
\hline
\end{tabular}

Another factor that may contribute to the environmental footprints is the WF of processing of biofuels (crushing, milling and refining) that is, however, small, requiring less than 1 $\mathrm{m}^{3} \mathrm{GJ}^{-1}$ (Williams \& Simmons, 2013) or none at all when the water from the crop itself is 
used (Gerbens-Leenes \& Hoekstra, 2013). In addition, emissions from mobile sources may be under- or overestimated in this study because all mobile emissions are calculated using emission data for trucks due to lack of data on emissions from maritime or aviation transport that are using biofuels. Nevertheless, emission savings calculated in this study are very large. Under- or overestimation of emissions from maritime and aviation sources would likely have a small effect on the overall results and conclusions.

\subsubsection{Practical implications of this study}

This paper demonstrates that the GHG emission savings of using bioenergy may come at a cost of significant use of land and water resources for crop cultivation or in some cases (i.e. rapeseed in a $100 \%$ scenario) lead to higher emissions than the current emissions. While for the GHG emissions, the location of emissions may ultimately be irrelevant, for land and water uses, local resource availability and timing of uses does matter (Hoekstra et al., 2011). This suggest, that addressing climate change can have adverse local implications and, reversely, that resource availability constrains the applicability of bioenergy.

Future research may consider focusing on individual crops at country level or for particular energy scenarios at the regional level to derive accurate estimates based on resource availability for sustainable first-generation bioenergy production. Knowledge on the process steps and resource availability at smaller scales may improve results and reveal how much bioenergy can be produced, the actual GHG emission savings from that bioenergy and their resource utilization rate. Conducting such a study in countries that already produce or plan to produce first-generation bioenergy can help governments make conscious decisions. Some policy recommendations stemming from this work are thus to avoid using first-generation biofuels altogether or set quantitative limits proportional to the amount of first-generation bioenergy that can be considered sustainable based on the resource availability of a consuming country. A revised directive of the EU "on the promotion of the use of energy from renewable sources" (European Commission, 2017) also acknowledges that the real contribution of "food-based biofuels" to the carbon reduction goal is uncertain and should be limited. However, it falls short of banning import of bioenergy.

\subsection{Conclusion}

This paper evaluated the land, water and carbon footprints of gross and net bioenergy generation. Two bioenergy production scenarios with different shares of bioenergy output and with different energy carrier composition were considered. The energy output was differentiated into net versus gross using a dynamic internal feedback loop that distinguishes the quality of input energy in the production systems. The results reflect a systematic attempt to reveal inherent trade-offs between land, water and carbon in the production of bioenergy from five selected feedstock crops and lead to four major conclusions. First, large scale first-generation bioenergy production should be avoided as their water and land requirements are too extensive. Second, $\mathrm{CHP}$ generation requires the least water and land resources regardless of the crop. Third, bioelectricity production is most efficient using sugarcane from LF, WF and CF perspectives while biofuel production is most efficient using sugar beet from the WF perspective and sugarcane from the LF and 
CF perspectives. Fourth, water and land requirements of bioethanol are much smaller than for biodiesel.

Large-scale first-generation bioenergy production is not feasible and should be avoided as the natural resource requirements are too large. Replacing even $9.8 \%$ of the final energy demand with bioenergy in the SDS-bio scenario requires several times more water than the current industrial WF or at least $17.6 \%$ of the current global water use, and at least $11.4 \%$ of the current global arable land. If bioenergy is still aimed for, to some degree, CHP generation can yield most bioenergy per unit of land and water, although mostly in the form of heat.

Among the five feedstock crops, sugar beet and sugarcane require the least water and land resources per unit of bioelectricity and biofuel energy output while also emitting the least amount of GHGs. In general, biodiesel production is less efficient than bioethanol production regardless of the choice of feedstock crops. 


\title{
3. The Environmental Footprint of Transport by Car Using Renewable Energy ${ }^{2}$
}

\begin{abstract}
Replacing fossil fuels in the transport sector by renewable energy will help combat climate change. However, lowering greenhouse gas emissions by switching to alternative fuels or electricity can come at the expense of scarce land and water resources. To understand the scale of this possible tradeoff we compare and contrast carbon, land and water footprints per driven $\mathrm{km}$ in midsize cars utilizing conventional gasoline, biofuels, bioelectricity, solar electricity and solar-based hydrogen. Results show that solar-powered electric cars have the smallest environmental footprints per $\mathrm{km}$, followed by solar-based hydrogen cars, and that biofuel-driven cars have the largest footprints.
\end{abstract}

\subsection{Introduction}

Human-driven emissions from fossil fuel combustion are the largest contributor to climate change (Pachauri et al., 2014). Climate change related risks are steering us towards developing innovative strategies and pathways that are quick in reducing greenhouse gas (GHG) emissions. The road to a low carbon world entails making decisions across sectors, with some sectors, such as transport having a large potential because of its large GHG emission contribution. The transport sector is responsible for $8 \mathrm{Gt}$ year-1 of $\mathrm{CO}_{2}$ emissions (a quarter of the global total) and road transport alone is responsible for about $74 \%$ of the sector's total emissions (IEA, 2018a). More than 1.2 billion cars are currently in operation (OICA, 2019b) while another 100 million new vehicles are produced annually (OICA, 2019a). The motorization rate (number of cars per population) is still higher in developed countries but increasing in all regions of the world (OICA, 2019b). In the last quarter of a century (1990-2016), emissions from the transport sector increased by 71\% (IEA, 2018a).

Although innovations to limit emissions from the transport sector are emerging, they are not equally efficient in terms of emission reduction and use of natural resources. For example, first generation biofuels require large water (D. Vanham et al., 2019) and land resources (Holmatov et al., 2019; Rulli et al., 2016). Vehicles that run on electricity or hydrogen can be considered clean technology (IRENA, 2019b; Transport \& Environment, 2018) only if the electricity and hydrogen are produced from renewable sources. In terms of market penetration, the number of vehicles using biofuels is not clear cut as the gasoline-biofuel blend ratios vary. In early 2019, the number of electric vehicles (i.e., battery powered electric vehicles, range extenders, plug-in hybrids) was about 5.6 million only, a $64 \%$ increase from a year earlier (ZSW, 2019). The number of hydrogen fuel cell electric vehicles (FCEVs) was even less, about 11200 at the end of 2018, serviced by only 376 refueling stations operating worldwide (IEA, 2019e). Together, battery electric

\footnotetext{
2 This chapter has been published as:

Holmatov, B., \& Hoekstra, A. Y. (2020). The environmental footprint of transport by car using renewable energy, Earth's Future, 8(2).

30
} 
vehicles (BEVs) and FCEVs make up less than $0.5 \%$ of 1.2 billion cars. It is interesting to compare and contrast environmental (i.e., carbon, land and water) footprints per unit of distance driven in vehicles utilizing alternative fuels or electricity to understand environmental tradeoffs linked to the choice of energy source as we transition towards low-carbon road transport.

Environmental footprint assessment is a common and handy tool to understand direct and indirect natural resources use and emissions related to a product or activity. The carbon, land and water footprint serve as different indicators of human pressure on the environment. Together, the three footprints can provide a broader understanding of environmental tradeoffs. To date, studies have looked at the land and water footprints of biofuels, but a systematic comparison of environmental footprints per unit of distance driven in vehicles using gasoline or a blend of biofuels or in BEVs or FCEVs is missing. Here we calculate the three footprints of midsize cars per unit of distance assuming different energy sources: (1) conventional gasoline; (2) 20\% biodiesel blend (B20), with biodiesel from rapeseed; (3) 85\% bioethanol blend (E85), with bioethanol from sugar beet; (4) electricity generated from burning sugarcane; (5) electricity generated from photovoltaic (PV) solar panels; and (6) hydrogen, produced through electrolysis using solar electricity. For calculations see Holmatov and Hoekstra (2020a).

\subsection{Materials and Methods}

Production of gasoline, biofuels, bioelectricity, solar electricity and solar-based hydrogen require energy, land and water during different stages of production. Land footprint, water footprint, and carbon footprint are members of the environmental footprint family (Davy Vanham et al., 2019), which includes other footprints not addressed in this study. Carbon footprint (CF) refers to GHG emissions produced in the supply chain of a product (Hoekstra \& Wiedmann, 2014). Land footprint (LF) refers to direct and indirect appropriation of land as a resource (Hoekstra \& Wiedmann, 2014). Water footprint (WF) refers to direct and indirect appropriation of freshwater and includes a blue component (consumption of surface and groundwater), a green component (consumption of rainwater), and a grey component (water required to assimilate pollution) (Hoekstra et al., 2011).

CFs of conventional diesel and gasoline are calculated using data from Zijlema (2018). CFs of biofuels and bioelectricity refer to emissions per unit of net energy output in a circular production system (whereby bioenergy is used to produce bioenergy) (Holmatov et al., 2019) with one adjustment. Specifically, the biofuel related emissions refer to fertilizer production and soil management stages, while the bioelectricity related emissions extend further to include combustion related emissions of nitrous oxide and methane in stationary power plants. CF of PV solar panel generated electricity is assumed zero if existing PV solar modules provide the input energy in a circular PV solar panel production system. CF of hydrogen is based on the total solar electricity consumed in production of hydrogen, thus also zero. 
LFs of conventional gasoline and diesel are obtained from Pękala et al. (2010). LFs of biofuels and bioelectricity are calculated using data from Holmatov et al. (2019). LF of solar electricity is calculated as the inverse of annual electricity generation per $\mathrm{m}^{2}$. Annual electricity generation assumptions are: average PV solar module efficiency is $16 \%$, solar insolation $1700 \mathrm{kWh} \mathrm{m}^{2}$ year-1, and performance ratio is $75 \%$ (for clarifications see Bhandari et al. (2015)). LF of hydrogen is based on the LF of total solar electricity consumed in the production of hydrogen.

WF of oil (assumed same as conventional gasoline or diesel) and solar electricity from PV modules are calculated using data from Mekonnen et al. (2015). WFs of biodiesel, bioethanol and bioelectricity are calculated using data from Holmatov et al. (2019) assuming rapeseed as the biodiesel feedstock, sugar beet as the bioethanol feedstock, and sugarcane as the bioelectricity feedstock. Footprint calculations of B20 and E85 fuels assume the following composition: $20 \%$ biodiesel and $80 \%$ conventional diesel in B20, and $85 \%$ bioethanol and $15 \%$ gasoline in E85. WF of hydrogen production through electrolysis is calculated in two steps as the direct WF, that is water as feedstock for electrolysis, and the indirect WF of solar PV generated electricity. Direct WF is based on the theoretical hydrogen gas produced when splitting water molecules, i.e. $112 \mathrm{~g} \mathrm{liter}^{-1}$ of water (8.9 liters $\mathrm{kg}^{-1}$ hydrogen). Indirect WF is linked to the WF of solar electricity from PV, where the electricity requirements are assumed as $47 \mathrm{kWh} \mathrm{kg}^{-1}$ hydrogen (Züttel et al., 2010) and the average of $3.1 \mathrm{kWh} \mathrm{kg}^{-1}$ hydrogen (USDOE, 2009) required for compression at the fueling station.

Energy contents (lower heating values) of biodiesel, bioethanol and hydrogen are obtained from USDOE (2014). Energy content (lower heating value) of conventional diesel and gasoline is calculated using data from IEA and OECD (2010). For comparison we assumed fuel efficiency of "midsize" sedan cars, which are defined as cars with passenger and cargo volume of 110-119 feet $^{3} \sim 3.1-3.4 \mathrm{~m}^{3}$ (USDOE, 2019c).

Fuel efficiency of an FCEV is obtained from USDOE (2019a) that corresponds to a 2019 Honda Clarity. Fuel efficiencies of all other vehicles are obtained from USDOE (2019b). Fuel efficiency of a conventional gasoline car corresponds to a 2019 Kia Forte FE or 2019 Toyota Camry. Fuel efficiency of a B20 vehicle corresponds to a 2019 Chevrolet Cruz Hatchback or 2019 Jaguar XF, while the fuel efficiency of an E85 vehicle corresponds to a 2016 Mercedes-Benz E350. The fuel efficiency of BEV corresponds to 2019 Honda Clarity EV or 2019 Nissan Leaf (40 kWh battery pack).

\subsection{Results}

Results show that solar-powered BEVs have the smallest environmental footprints per km (Table 3.1), while biofuel-driven cars have the largest footprints. Driving a car with B20 blend has the worst environmental performance. Driving a car with E85 blend gives the second-largest land and water footprints, while conventional gasoline gives the secondlargest carbon footprint. Interestingly gasoline-based cars have the smallest associated land footprint per driven $\mathrm{km}$ and the second smallest water footprint. 
Table 3.1. Carbon, land and water footprint per $\mathrm{km}$ and per capita year ${ }^{-1}$ of driving a car fueled by conventional gasoline, biodiesel blend B20, bio-ethanol blend E85, bioelectricity, solar electricity or solar-based hydrogen.

\begin{tabular}{|c|c|c|c|c|c|c|}
\hline & \multirow{2}{*}{ Gasoline } & \multicolumn{2}{|c|}{$\begin{array}{c}\text { Biofuel } \\
\text { blend }\end{array}$} & \multicolumn{2}{|c|}{ Electricity } & \multirow{2}{*}{$\begin{array}{l}\text { Hydrogen } \\
\text { Solar (PV)* }\end{array}$} \\
\hline & & $\mathrm{B} 20^{1, \mathrm{a}}$ & $\mathrm{E}^{2} 5^{2, \mathrm{a}}$ & $\mathrm{Bio}^{3, \mathrm{a}}$ & Solar (PV)* & \\
\hline Carbon footprint $\left(\mathrm{g} \mathrm{CO}_{2} \mathrm{eq} / \mathrm{km}\right)$ & 165 & $185^{\mathrm{b}}$ & $80.2^{\mathrm{b}}$ & $7.3^{\mathrm{b}}$ & 0 & 0 \\
\hline Land footprint $\left(\mathrm{m}^{2} / \mathrm{km}\right)$ & 0 & 0.37 & 0.21 & 0.028 & 0.00091 & 0.0023 \\
\hline Water footprint $(\mathrm{L} / \mathrm{km})$ & 0.25 & 170 & 163 & 40 & 0.12 & 0.39 \\
\hline Carbon footprint (kg CO $2 \mathrm{eq} /$ driver/year) & 3579 & 4010 & 1739 & 158 & 0 & 0 \\
\hline Land footprint $\left(\mathrm{m}^{2} /\right.$ driver/year) & 0 & 7977 & 4463 & 611 & 20 & 50 \\
\hline Water footprint ( $\mathrm{m}^{3} /$ driver/year) & 5 & 3685 & 3534 & 859 & 3 & 8 \\
\hline
\end{tabular}

Notes: ${ }^{1} 20 \%$ biodiesel from rapeseed and $80 \%$ conventional diesel; ${ }^{2} 85 \%$ bioethanol from sugar beet and $15 \%$ conventional gasoline; ${ }^{3}$ From sugarcane's biomass; a Assuming circular production (using bioenergy to produce bioenergy); ${ }^{\mathrm{b}}$ The CF of biofuels originates from nitrogen fertilizer production and soil management while the CF of bioelectricity also includes nitrous oxide and methane emissions during combustion; * Assuming circular production (using solar PV panels to make solar PV panels). Fuel efficiencies refer to: 2019 Kia Forte FE or 2019 Toyota Camry for conventional gasoline; 2019 Chevrolet Cruze Hatchback for B20; 2016 Mercedes-Benz E350 for E85; 2019 Honda Clarity EV or 2019 Nissan Leaf (40kWh battery pack) for electric; and 2019 Honda Clarity for hydrogen. We assume here the average annual travel distance as in the US (FHWA, 2018), which is $21687 \mathrm{~km}$

Switching from gasoline to BEV cars gives an emission saving per $\mathrm{km}$ of $96 \%$ in case of bioelectricity and 100\% in case of solar electricity. Driving a B20 fueled car will actually increase emissions per $\mathrm{km}$ by $12 \%$ while requiring 683 times more water than a gasoline car. A E85-based car can cut emissions by half but will require 655 times more water compared to gasoline. A solar-based FCEV can achieve $100 \%$ emission reduction but requires 58\% more water than driving a gasoline car. The indirect water footprint of a solar-based FCEV (i.e., the water consumed in the supply chain of solar electricity) is over three times larger than its direct water footprint (the water used to produce hydrogen) (Figure 3.1.).

Gasoline has the smallest land footprint (related to land occupied by mining and refineries), thus switching from gasoline to any of the considered alternative energy sources will increase the land requirement. A solar-based BEV or FCEV has an order of magnitude smaller land footprint than a bio-based vehicle. 


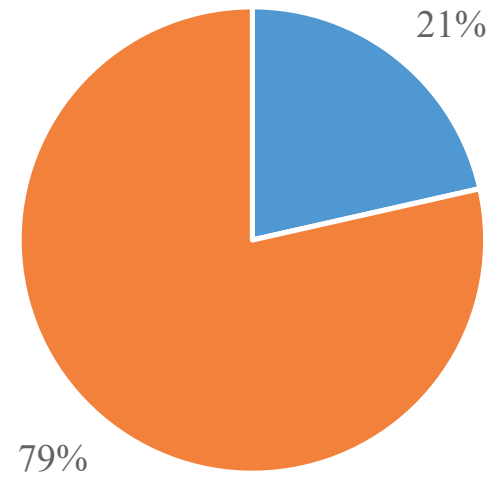

- Direct water footprint (water splitting) - Indirect water footprint (solar PV electricity)

Figure 3.1. Breakdown of the water footprint of hydrogen production using solar based electricity.

To put things into perspective, the average annual driving distance per car driver in the US is 13,476 miles (FHWA, 2018) or 21,687 km. Driving a gasoline car translates into 3.58 tonnes of $\mathrm{CO}_{2}$ eq emissions and $5 \mathrm{~m}^{3}$ of water consumption per year. From the GHG emissions perspective, using solar-based BEV or FCEV emits $0 \mathrm{~kg}$ of $\mathrm{CO}_{2}$ eq. A BEV powered by bioelectricity emits $158 \mathrm{~kg}$ of $\mathrm{CO}_{2}$ eq per year. If we add the water perspective, a solar-based BEV requires only $3 \mathrm{~m}^{3}$ of water per year, followed by a solar-based FCEV $\left(8 \mathrm{~m}^{3}\right)$, while a bioelectricity based BEV requires $859 \mathrm{~m}^{3}$ and an E85-powered car 3,534 $\mathrm{m}^{3}$. A B20 fuelled car has the worst performance, emitting over 4 tonnes of $\mathrm{CO}_{2}$ eq year-1 while requiring $3,685 \mathrm{~m}^{3}$ of water and 7,977 $\mathrm{m}^{2}$ every year.

The least GHG emissions can be achieved driving a solar-based BEV or FCEV. If we add the land and water perspective, a solar powered BEV becomes the most resource efficient vehicle per unit of distance.

\subsection{Conclusions}

The environmental performance of different cars depends on the choice of energy source. We show inherent tradeoffs between land use, water use and carbon emissions. From the environmental footprint perspective, solar-powered battery-electric vehicles are the most resource efficient per unit of distance, followed by solar-based hydrogen-driven vehicles. Biodiesel has the worst resource use efficiency per unit of distance while bioethanol has smaller emissions compared to fossil fuels but has extremely large land and water requirements. The logical choice of future transport is thus diffusion of electric and hydrogen vehicles based on (non-biomass) renewable energy sources. 


\title{
4. EU's bioethanol potential from wheat straw and maize stover and the environmental footprint of residue-based bioethanol
}

\begin{abstract}
To reduce greenhouse gas (GHG) emissions, the European Union (EU) has targets for utilizing energy from renewable sources. By 2030, a minimum of $3.5 \%$ of energy in the EU's transport sector should come from renewable biological sources, such as crop residue. This paper analyzes EU's 'advanced bioethanol' potential from wheat straw and maize stover and evaluates its environmental (land, water and carbon) footprint. We differentiate between gross and net bioethanol output, the latter by subtracting the energy inputs in production. Results suggest that the annual amount of the sustainably harvestable wheat straw and maize stover is $81.9 \mathrm{M}$ tonnes at field moisture weight (65.3 $\mathrm{M}$ tonnes as dry weight), yielding $470 \mathrm{PJ}$ as gross (404 PJ as net) advanced bioethanol output. Calculated gross advanced bioethanol can replace $3.44 \%$ of EU transport sector's energy consumption. EU's advanced bioethanol has a land footprint of $0.28 \mathrm{~m}^{2} \mathrm{MJ}^{-1}$ for wheat straw and $0.18 \mathrm{~m}^{2} \mathrm{MJ}^{-1}$ for maize stover. The average water footprint of advanced bioethanol is $173 \mathrm{~L} \mathrm{MJ}^{-1}$ for wheat straw and $113 \mathrm{~L} \mathrm{MJ}^{-1}$ for maize stover. The average carbon footprint per unit of advanced bioethanol is 19.4 and $19.6 \mathrm{~g} \mathrm{CO}_{2} \mathrm{eq} \mathrm{MJ}^{-1}$ for wheat straw and maize stover, respectively. Using advanced bioethanol can lead to emission savings, but the EU's advanced bioethanol production potential is insufficient to achieve the EU's target of a minimum share of $3.5 \%$ of advanced biofuels in the transport sector by 2030 and the associated water and land footprints are bigger than the footprints of conventional bioethanol.
\end{abstract}

\subsection{Introduction}

The climate of our planet is changing as a result of emissions of greenhouse gases (GHGs) from the consumption of fossil fuels (Edenhofer et al., 2011). Fossil fuels are mainly used as a source of energy across different sectors. By switching from fossil fuels to renewable energy sources, we may be able to reduce GHG emissions and limit the rate and magnitude of climate change.

Transport sector emissions constitute a quarter of global GHG emissions (IEA, 2018a). The energy policy of the European Union (EU) requires a minimum of $14 \%$ of the final consumption in the transport sector to come from renewable sources by 2030 (European Commission, 2018). Moreover, the policy sets a minimum target of $3.5 \%$ of the final transport sector's energy consumption that shall originate from advanced biogas or biofuels (European Commission, 2018). Advanced biofuels are defined as liquid fuels produced from a specific type of feedstock, such as: algae, biowaste, agricultural residues, used cooking oil, animal fats, manure, etc. (for a complete list see EU Directive 2018, Annex IX), as opposed to conventional (first-generation) biofuels produced from crops. Advanced biofuels from agricultural residues are also called lignocellulosic biofuels. 
Although we could theoretically produce a range of biofuel products using biomass feedstock, most forms of advanced biofuel production are still in a research or demonstration stage (IRENA, 2016a). Some of the available technologies, such as thermochemical conversion of biomass to syngas or pyrolysis oils don't yield transportready biofuels but intermediate products that need further processing and input of hydrogen to become transport-ready fuels (Karatzos et al., 2014). Present-day advanced biofuel plants operating at the commercial scale mainly produce bioethanol using plant residues (IEA, 2019c). Considering the EU's current energy policy, it would be good to know how much advanced biofuel can be produced using available crop residues. In addition, it would be good to know natural resource appropriation and GHG emissions in the production of advanced biofuels in order to compare them to conventional biofuels.

Various studies have assessed the agricultural residue potential of the EU in terms of weight (Searle \& Malins, 2016) or energy equivalents using the heat content of residues (EEA, 2006; Ericsson \& Nilsson, 2006; Scarlat et al., 2010). Scarlat et al.(2010), for example, estimated the EU's bioenergy potential in terms of heat content from crop residues, when using the portion of agricultural residues remaining after environmental considerations and current uses. Heat content of biomass, however, is not the same as energy in the form of biofuel. Fisher et al. (2007) estimate EU's advanced biofuel potential at 8 Exa-joules by 2030, but they considered woody plants (i.e., poplar, willow, eucalypt) and herbaceous lignocellulosic plants (i.e., miscanthus, switchgrass, and reed canary grass). No study has assessed the sustainable advanced bioethanol potential of the EU from crop residues.

To fill this gap, this study estimates the EU's advanced bioethanol potential from wheat straw and maize stover. Cereals are the main crops grown in the EU with wheat and maize making up $48 \%$ and 19\% of the cereals production, respectively (Eurostat, 2017). In addition, the study quantifies the environmental footprint of advanced bioethanol, more specifically the land, water and carbon footprints. Footprint assessment has been applied previously to analyze resource appropriation and emissions in the production of biofuels (Gerbens-Leenes et al., 2014; Gerbens-Leenes \& Hoekstra, 2012; Mathioudakis et al., 2017) and electricity (de Wild-Scholten, 2013; Mekonnen et al., 2015; Mekonnen et al., 2016; Mekonnen \& Hoekstra, 2012; Zhang \& Xu, 2015), but to date, no study has comprehensively assessed the land, water and carbon footprints of advanced bioethanol in the EU from crop residues.

\subsection{Methods and data}

\subsubsection{Resource inputs}

Overview of production phases and output products

As feedstock for the production of lignocellulosic bioethanol, we assume wheat straw and maize stover produced in member states of the EU in 2017. We distinguish between resource inputs in the agriculture phase and the conversion phase (Fig. 4.1.). The outputs from the agriculture phase are crop grains and residues while the outputs from the conversion phase are bioethanol and electricity. Considering the bulkiness of crop 
residues, a suggested distance of $50 \mathrm{~km}$ on average is assumed between the agricultural field and biorefinery (Spöttle M., 2013).

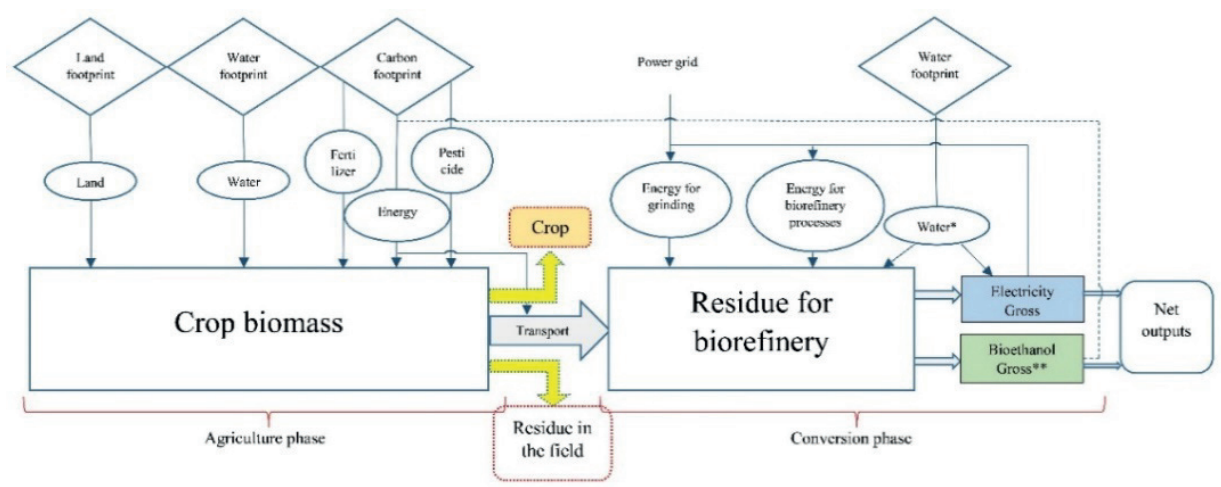

Fig. 4.1. Schematic representation of resource inputs in the production of advanced bioethanol. Notes: * Water is mainly lost due to evaporation; ${ }^{* *}$ Distinction between gross and net bioethanol is applied to show the difference in energy balance but does not affect the carbon footprint calculation. The carbon footprint in the agriculture phase is calculated assuming diesel input.

\subsubsection{Inputs during the agriculture phase}

Crop production, harvested area and yield data for individual EU countries are obtained from Eurostat for 2017 (Eurostat, 2019d). No data were available for Malta, which is therefore excluded from this study. Maize production refers to maize harvested for grain and excludes green maize used for fodder, maize grown for producing first-generation biofuel and sweet corn used for human consumption (Eurostat, 2019a). Maize production data were not available for Cyprus, Estonia, Finland, Ireland and Latvia, and thus, our estimation of bioethanol production potential from maize residues excludes these countries. Wheat yield data for 2017 were not available for Italy, the Netherlands and the United Kingdom; the latest available data from 2016 were used instead. Maize and wheat yields are converted to straw and stover yields using crop residue-to-yield correlations proposed by Scarlat et al (2010).

Resource inputs during the agriculture phase are land, water, fertilizer, pesticide and fuel energy (Table 4.1.). For technical and environmental reasons, only part of the residue can be collected to generate bioethanol. Removing even part of the residues (30-40\%) can lead to a number of side-effects, including soil erosion, additional emission of GHGs, depletion of the soil organic carbon pool, etc. (Lal, 2005). Consistent with Scarlat et al. (2010) we assume that maximally $50 \%$ of maize stover and $40 \%$ of the wheat straw can be sustainably removed from fields in European conditions. Harvested wheat straw moisture is assumed to be $15 \%$ and maize stover moisture is assumed to be $30 \%$ (Scarlat et al., 2010). Moreover, the least dry matter loss of $6 \%$ is assumed during bale storage in the field (POET-DSM, ND). Throughout this work, dry weight is converted to harvested moisture weights through:

$$
H W(r)=\frac{D W(r)}{d m c(r)}
$$


where $H W(r)$ is the harvested moisture weight of residue feedstock $r$ (in mass units); $D W(r)$ is the dry weight of the residue feedstock (mass units); and $d m c(r)$ is the dry matter content of the harvested residue feedstock (expressed as a fraction).

Table 4.1. Resource inputs during the agriculture phase of the bioethanol production.

\begin{tabular}{|c|c|c|c|c|c|}
\hline \multirow{2}{*}{$\begin{array}{l}\text { Resource } \\
\text { input }\end{array}$} & \multirow[t]{2}{*}{ Process } & \multicolumn{2}{|c|}{ Value } & \multirow[t]{2}{*}{ Units } & \multirow[t]{2}{*}{ Source } \\
\hline & & $\begin{array}{l}\text { Wheat } \\
\text { straw }\end{array}$ & $\begin{array}{l}\text { Maize } \\
\text { stover }\end{array}$ & & \\
\hline Water & $\begin{array}{c}\text { Crop } \\
\text { cultivation }\end{array}$ & $\begin{array}{c}\text { Varies by } \\
\text { country }\end{array}$ & $\begin{array}{l}\text { Varies by } \\
\text { country }\end{array}$ & $\begin{array}{c}\mathrm{m}^{3} \text { tonne } \\
{ }^{1}(\mathrm{crop})\end{array}$ & $\begin{array}{c}\text { Mekonnen } \\
\text { and Hoekstra } \\
\text { (2010) }\end{array}$ \\
\hline \multirow{2}{*}{$\begin{array}{l}\text { Fertilizers } \\
\text { (N\&P) }\end{array}$} & \multirow{2}{*}{$\begin{array}{c}\text { Crop } \\
\text { cultivation }\end{array}$} & $\begin{array}{l}N: 180 \\
(201.8)\end{array}$ & $\begin{array}{l}\mathrm{N}: 80 \\
(89.7)\end{array}$ & \multirow{2}{*}{$\begin{array}{c}\mathrm{lb} \mathrm{ac}-1 \\
\left(\mathrm{~kg} \mathrm{ha}^{-1}\right)\end{array}$} & \multirow{2}{*}{ Kissel (ND) } \\
\hline & & $\begin{array}{l}\text { P: } 90 \\
(100.9)\end{array}$ & $\begin{array}{l}\text { P: } 40 \\
(44.8)\end{array}$ & & \\
\hline $\begin{array}{l}\text { Pesticide } \\
\text { related } \\
\text { energy }\end{array}$ & $\begin{array}{c}\text { Crop } \\
\text { cultivation }\end{array}$ & 571 & 1681 & MJ ha-1 & $\begin{array}{l}\text { Audsley et } \\
\text { al. (2009) }\end{array}$ \\
\hline \multirow{4}{*}{$\begin{array}{c}\text { Diesel } \\
\text { (energy) }\end{array}$} & $\begin{array}{c}\text { Crop } \\
\text { cultivation } \\
\text { (field } \\
\text { activities) }\end{array}$ & $35.5^{*}$ & $37.5^{* *}$ & L ha & $\begin{array}{c}\text { Šarauskis et } \\
\text { al. (2014) } \\
\text { Dalgaard et } \\
\text { al. (2001) }\end{array}$ \\
\hline & $\begin{array}{l}\text { Residue } \\
\text { harvest } \\
\text { (mowing) }\end{array}$ & 5 & 5 & $\mathrm{~L} \mathrm{ha}^{-1}$ & $\begin{array}{l}\text { Dalgaard et } \\
\text { al. (2001) }\end{array}$ \\
\hline & $\begin{array}{c}\text { Residue } \\
\text { harvest } \\
\text { (bailing \& } \\
\text { handling) }\end{array}$ & 2 & 2 & L tonne $^{-1}$ & $\begin{array}{l}\text { Dalgaard et } \\
\text { al. (2001) }\end{array}$ \\
\hline & $\begin{array}{l}\text { Residue } \\
\text { transport }^{\mathrm{a}}\end{array}$ & 0.2 & 0.2 & $\begin{array}{l}\text { L tonne } \mathrm{e}^{-1} \\
\mathrm{~km}^{-1}\end{array}$ & $\begin{array}{c}\text { Dalgaard et } \\
\text { al. (2001) }\end{array}$ \\
\hline
\end{tabular}

Notes: *Refers to the sum of the following field activities: stubble cultivation; shallow ploughing, pre-sowing, fertilization, conventional drilling and spraying; ${ }^{*}$ Refers to the sum of the following field activities: stubble cultivation; ploughing $(21 \mathrm{~cm})$; seedbed harrowing; fertilization; sowing and spraying; a Same as the energy requirement of fodder transport.

All inputs during the agriculture phase are partly allocated to bioethanol, based on the value of the bioethanol output compared to the summed value of all final outputs (crop, bioethanol, and electricity output). This value fraction is calculated as: 


$$
f_{v}(B E)=\frac{\operatorname{price}(B E) \times w(B E)}{\sum_{p=1}^{3}((\operatorname{price}(p) \times w(p))}
$$

where $f_{v}(B E)$ is the value fraction of bioethanol, price $(B E)$ the price of bioethanol, and $w(B E)$ the quantity of gross bioethanol. The denominator is the sum of the total values of the three output products (crop yield, gross bioethanol and gross electricity), whereby total values follow from price time quantity. In the case of diesel inputs for residue mowing, bailing and handling, and for residue transport, the footprints of that diesel are allocated to two output products (bioethanol and electricity).

Crop prices for 2017 are taken from the Eurostat (2019c) database. Wheat prices were not available for 12 countries: Belgium, Cyprus, Denmark, Estonia, Ireland, France, Latvia, Finland, Spain, Sweden, the Netherlands and the UK. For Spain and France, the latest available wheat prices were for 2016 and were utilized in this study. For all other countries, the wheat price is assumed at the average wheat price in the $15 \mathrm{EU}$ countries with available data. The latest available maize price data for Spain and France were from 2016 and were utilized in this study. For the price of bioethanol we took the price of European duty-paid ethanol in July 2017 from ICIS (2017). The price of electricity for household consumption per country in 2017 is calculated using the bi-annual electricity price data from Eurostat (2019b).

\subsubsection{Inputs during the conversion phase}

Resource inputs during the conversion phase are energy, water and residues (Table 4.2). The electricity requirement for grinding biomass to the size of $0.5 \mathrm{~mm}$ is taken from German \& Bauen (2018). The water input in the biorefinery is allocated to bioethanol as in equation 2 (with two output products: bioethanol and electricity).

Table 4.2. Resource inputs per liter of bioethanol output during the conversion phase.

\begin{tabular}{|c|c|c|c|}
\hline Resource input & Value & Units & Source \\
\hline Electricity (plant use) & 1.03 & $\mathrm{kWh} \mathrm{L-1}$ & $\begin{array}{l}\text { Humbird et al. } \\
\qquad(2011)\end{array}$ \\
\hline $\begin{array}{c}\text { Consumptive water } \\
\text { use }\end{array}$ & 5.4 & $\mathrm{~L} \mathrm{~L}^{-1}$ & $\begin{array}{l}\text { Humbird et al. } \\
\qquad(2011)\end{array}$ \\
\hline $\begin{array}{c}\text { Electricity (grinding) } \\
\text { wheat straw }\end{array}$ & $0.138^{*}$ & $\mathrm{kWh} \mathrm{L-1}$ & $\begin{array}{c}\text { German \& Bauen } \\
(2018)\end{array}$ \\
\hline $\begin{array}{l}\text { Electricity (grinding) } \\
\text { maize stover }\end{array}$ & $0.174^{*}$ & $\mathrm{kWh} \mathrm{L-1}$ & $\begin{array}{c}\text { German \& Bauen } \\
\text { (2018) }\end{array}$ \\
\hline Wheat straw & $2.922^{* *}$ & $\mathrm{~kg}\left(\right.$ dry) $\mathrm{L}^{-1}$ & Saha et al. (2015) \\
\hline Maize stover & 3.039 & $\operatorname{kg}\left(\right.$ dry) $\mathrm{L}^{-1}$ & O'Connor (2013) \\
\hline
\end{tabular}

Notes: ${ }^{*}$ Calculated from a reported requirement of $40 \mathrm{kWh}$ per tonne of feedstock; ${ }^{* *}$ Calculated from a yield of 0.27 gram of bioethanol per gram of wheat straw after 76 hours.

Co-production of electricity in a biorefinery is calculated using data from Humbird et al. (2011). In addition to the electricity for the plant's own use, an excess of $1.8 \mathrm{kWh}$ per gallon of bioethanol $\left(0.48 \mathrm{kWh} \mathrm{L}^{-1}\right)$ can be generated using lignin and post-processed insoluble solids. Electricity generation from wheat straw processing is assumed similar to maize 
stover processing because of similar lignin composition in wheat straw and maize stover (Jia et al., 2013).

\subsubsection{Energy balance}

The net energy yield in terms of bioethanol is calculated as the gross bioethanol output minus the energy inputs during production (see Fig. 1). During the agriculture phase, energy inputs are associated with the direct input of diesel and with the embedded energy in the pesticides and fertilizers applied. Energy equivalent units for these inputs are subtracted from the gross bioethanol output. The lower heating value (LHV) of bioethanol is taken from USDOE (2014). LHV of diesel is calculated from IEA \& OECD (2010). The energy used in fertilizer (ammonium nitrate and triple superphosphate) production (expressed per weight of product) is taken from Fertilizers Europe (2019). The energy used in pesticide production is taken from Audsley et al. (2009).

During the conversion phase, electricity is used for grinding and biorefinery. This electricity input is subtracted from the gross electricity output to get net electricity output.

\section{Land footprint}

The land footprint of bioethanol production is associated with the agriculture phase only. It is calculated as the inverse of the net bioethanol output per hectare (which gives the total area used per unit of net bioethanol produced) multiplied by the value fraction for bioethanol (which allocates only a part of the total area to the bioethanol output).

\section{Water footprint}

The water footprint of bioethanol consists of (1) agricultural water requirements for crop cultivation and (2) processing water requirements at the biorefinery. The water footprint of the agriculture phase is composed of blue, green and grey components while the water footprint of conversion phase is only blue water. The blue water footprint refers to consumptive use of irrigation water; the green water footprint refers to consumption of rainwater; and the grey water footprint refers to water pollution (in this study we only consider water pollution through nitrogen, which is applied on the cropland as fertilizer). Country-average data on the water footprint of crops per weight is taken from Mekonnen and Hoekstra (2010). The water footprint per weight of crop is first converted to water footprint per hectare using the country-specific crop yields and then allocated to bioethanol based on the value fraction of gross bioethanol.

Processing water requirement at the biorefinery is reported as consumptive water usage, mainly due to evaporative losses (Humbird et al., 2011). Water input in the biorefinery is also allocated to bioethanol based on the value fraction of bioethanol. The water footprint per unit of net bioethanol output is calculated by dividing total water inputs for bioethanol production by the total net bioethanol output.

\section{Carbon footprint}

The carbon footprint of bioethanol production is associated with the agriculture phase only. It is the sum of the GHG emissions from diesel combustion and the GHG emissions 
related to fertilizer and pesticide production and use. The $\mathrm{CO}_{2} \mathrm{eq}$ emission factor of diesel combustion is obtained from Zijlema (2018). Fertilizer production and use emissions are calculated by multiplying fertilizers applied to the field (Table 1) by their respective total $\mathrm{CO}_{2}$ eq emissions during production and use (soil effects) from Fertilizers Europe (2019). Pesticide production and use related emissions are calculated by multiplying pesticide applied to the field (Table 1) by the $\mathrm{CO}_{2}$ eq emission factor suggested by Audsley et al. (2009). The carbon footprint per unit of net bioethanol output is calculated by allocating the $\mathrm{CO}_{2}$ eq emissions per hectare to bioethanol based on the value fraction of gross bioethanol and dividing by the net bioethanol output per hectare.

\subsection{Results}

\subsubsection{Residue availability in the EU}

The total amount of residue from wheat and maize available for biorefineries is estimated at $81.9 \mathrm{M}$ tonnes at field moisture weight, which is equivalent to $65.3 \mathrm{M}$ tonnes as dry weight. The latter figure is very similar to the amount reported by Scarlat et al. (2010), who estimated that maize and wheat together contribute $60 \%$ (i.e., $66.6 \mathrm{M}$ tonnes) to the total of $111 \mathrm{M}$ tonnes dry residue weight that can be sustainably collected in the EU (without counting the $6 \%$ bailing loss considered in this study).

Wheat straw at field moisture contributes $65 \%$ to the total residue calculated in this study, with the remaining $35 \%$ being maize stover. In terms of dry weight, wheat straw contributes $69 \%$ and maize stover $31 \%$ to the total combined residue. The largest producers of total combined residue calculated in this study are France, Germany, and Romania. France produces $22.9 \%$, Germany $12.3 \%$ and Romania $12.1 \%$ of the total residues.

France produces the largest amount $(23.7 \%)$ of wheat straw in the EU, followed by Germany (14.8\%) (Fig. 4.2). The United Kingdom, Poland and Romania are the other big contributors, producing $8.4 \%, 8.3 \%$ and $7.2 \%$ of EU's wheat straw, respectively. 


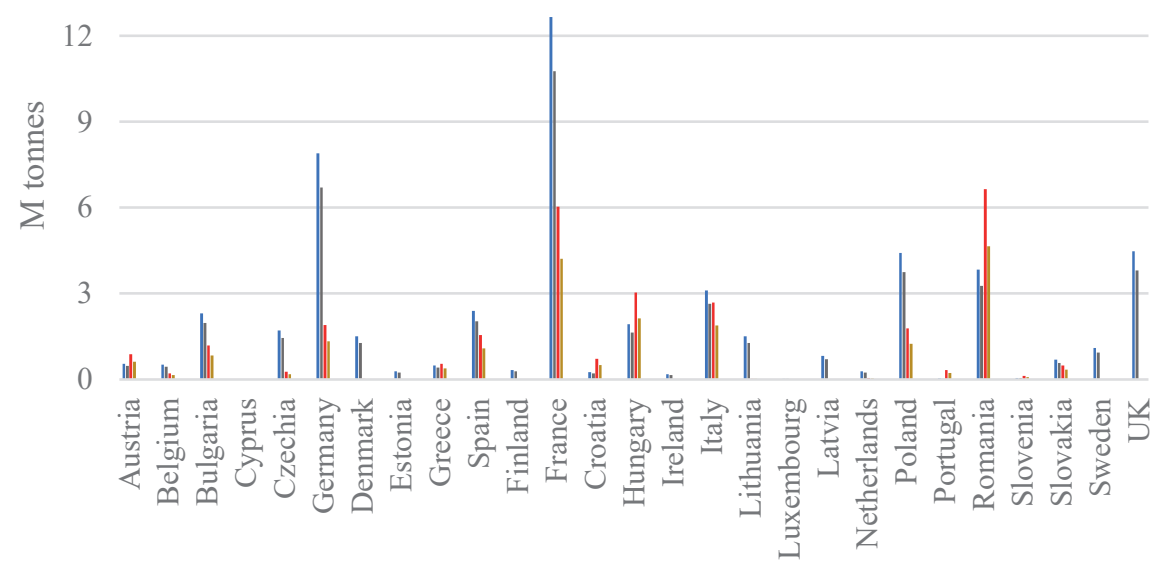

■ Wheat field weight $\square$ Wheat dry weight $\square$ Maize field weight $\square$ Maize dry weight

Fig. 4.2. Wheat straw and maize stover availability for bioethanol production per EU country.

The largest producer of maize stover is Romania, which contributes $23.3 \%$ to the EU's total maize stover production, followed by France (21.2\%). Next in line are Hungary $(10.7 \%)$, and Italy $(9.4 \%)$.

\subsubsection{Advanced bioethanol production potential in the EU}

Total bioethanol production potential from wheat and maize residue in the EU is $470 \mathrm{PJ}$ as gross output or $404 \mathrm{PJ}$ as net output. The potentially largest producer of advanced bioethanol from wheat straw and maize stover in the EU is France, which could produce $23.6 \%$ of the total European potential (Fig. 4.3). Germany and Romania can produce $12.9 \%$ and $11.6 \%$ of the total potential net bioethanol from wheat and maize residues, respectively. 


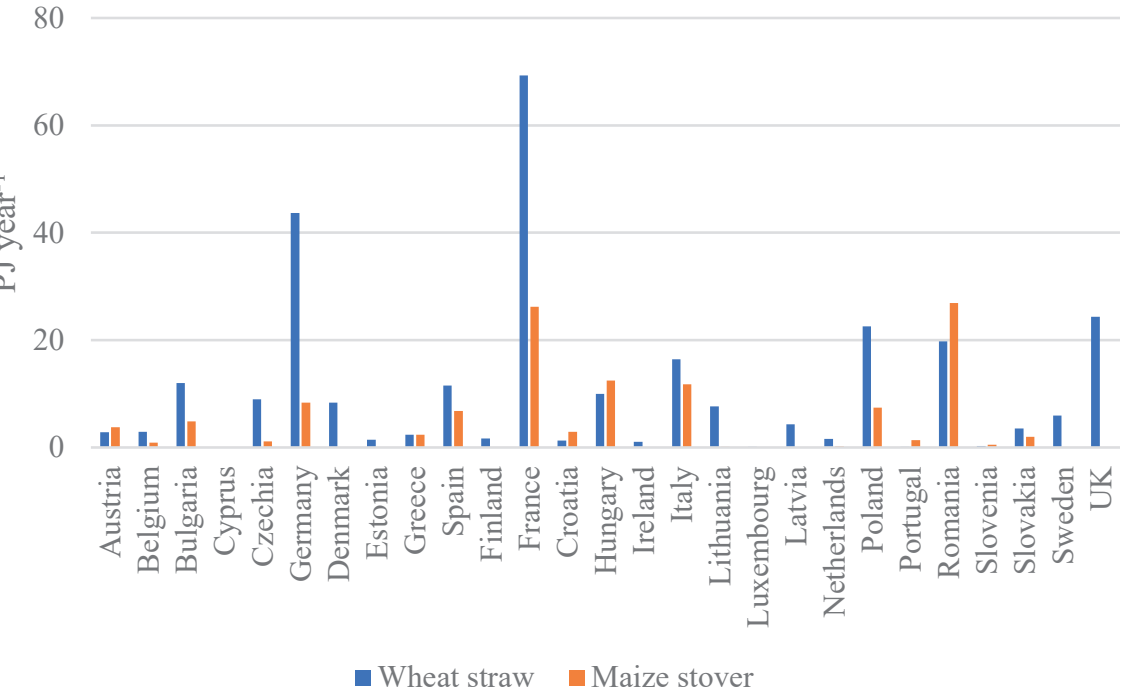

Fig. 3. Net bioethanol production potential from wheat straw and maize stover per EU country.

Net bioethanol production from wheat straw is $284 \mathrm{PJ}$ (70\% of the total), while net bioethanol production from maize stover is $120 \mathrm{PJ}$ (30\%). Total potential net bioethanol production from wheat and maize in the EU is slightly over 19 billion liters. Total EU produced advanced bioethanol can replace $3.44 \%$ (using gross bioethanol output) or $2.95 \%$ (using net bioethanol output) of the EU's final energy consumption in the transport sector (326.872 Mtoe or 13685 PJ in 2017) (Eurostat, 2019 ). Separately, gross bioethanol from wheat straw can replace $2.41 \%$ and gross bioethanol from maize stover $1.02 \%$ of EU's final energy consumption in the transport sector.

Net bioethanol production from residues per hectare is higher for the case of maize than for the case of wheat (Fig. 4.4). The average net bioethanol yield from wheat straw in the EU is $10.3 \mathrm{GJ} \mathrm{ha}^{-1}$ while the average net bioethanol yield from maize stover is $14.7 \mathrm{GJ} \mathrm{ha}^{-1}$. These values are lower than net first-generation bioethanol yields, which are $29.1 \mathrm{GJ} \mathrm{ha}^{-1}$ for maize, 139.6 GJ ha-1 for sugar beet and $142 \mathrm{GJ} \mathrm{ha}^{-1}$ for sugarcane (Holmatov et al., 2019). Yields of advanced bioethanol vary between countries and between the two types of feedstock. For example, net bioethanol yield from wheat straw in the UK (13.6 GJ ha-1) is higher than the EU's average and higher than net bioethanol yield from maize stover in the UK (9.1 GJ ha-1). The highest net bioethanol yield from wheat straw is in Ireland (15.4 $\mathrm{GJ} \mathrm{ha}^{-1}$ ) and the lowest in Cyprus $\left(4.4 \mathrm{GJ} \mathrm{ha}^{-1}\right)$. The highest net bioethanol yield from maize stover is in Spain (20.3 GJ ha-1) and the lowest in the UK (9.1 GJ ha $\left.{ }^{-1}\right)$. 


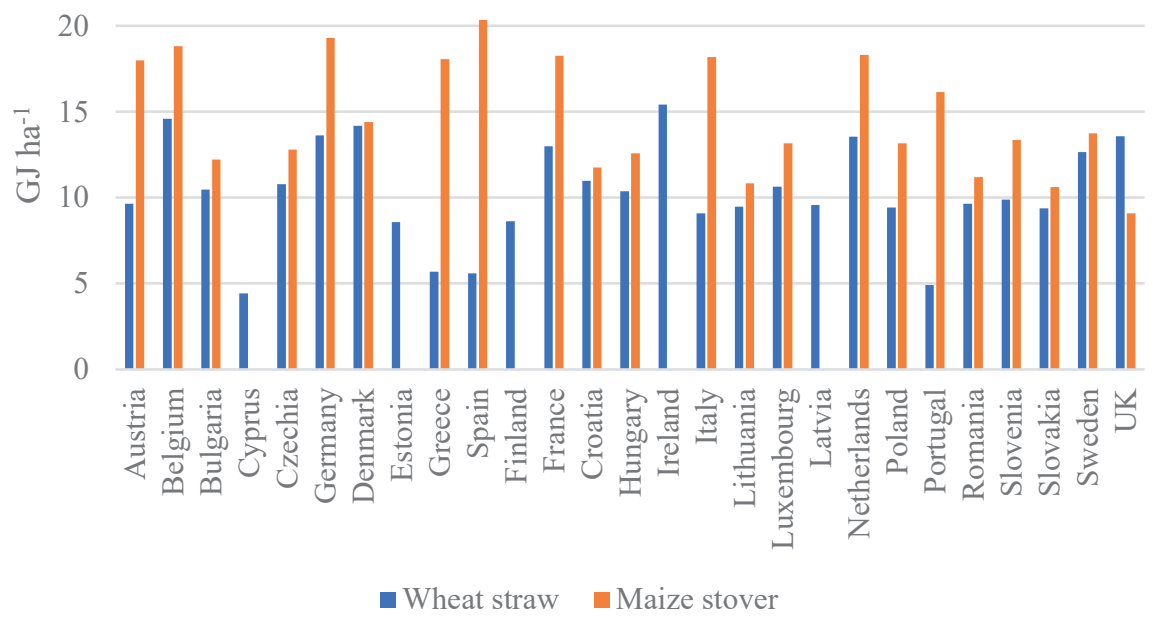

Fig. 4.4. Net bioethanol yield from wheat straw and maize stover per hectare across EU countries.

The average difference between net and gross bioethanol output from wheat straw is $15 \%$. In Cyprus, this loss is $28 \%$ (4.4 GJ ha-1 as net vs $6.2 \mathrm{GJ} \mathrm{ha}^{-1}$ as gross) while in Belgium the loss is only $10 \%$ (14.6 vs 16.3). The average difference between net and gross bioethanol output from maize stover is $13.6 \%$. The largest difference is found for the UK, namely $17.7 \%$ (9.1 vs 11), while the smallest difference is in Germany, namely $10.3 \%$ (19.3 vs 21.5).

\subsubsection{Bioelectricity co-generation potential in the EU}

The bioelectricity co-generation potential in the EU related to the production of advanced bioethanol from wheat straw and maize stover is $7232 \mathrm{GWh}$ or 26 PJ. Using wheat straw can co-produce $5250 \mathrm{GWh}$ or $73 \%$ of the total co-generated bioelectricity. France alone can co-generate $1245 \mathrm{GWh}$ of bioelectricity from post-processed wheat straws (Fig. 4.5). In terms of energy, total co-generated bioelectricity is equivalent to $6.4 \%$ of the total net bioethanol's energy (26 PJ vs 404 PJ). 


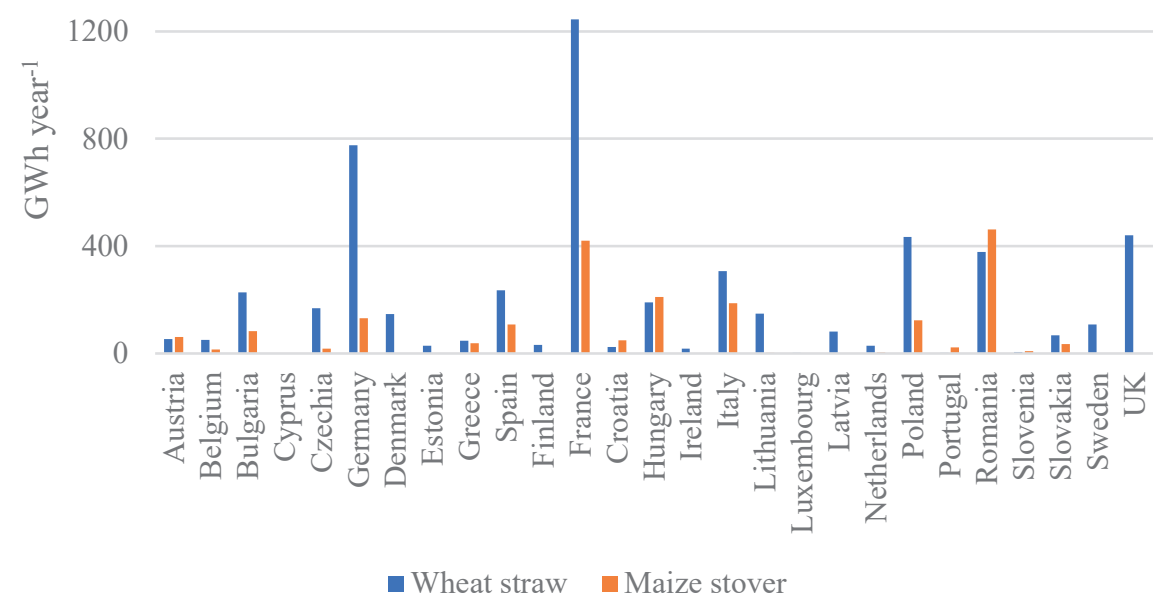

Fig. 4.5. Bioelectricity co-generation with advanced bioethanol from wheat straw and maize stover per EU country.

\subsubsection{Land footprint of advanced bioethanol}

EU's average land footprint per unit of net advanced bioethanol from wheat straw is 0.28 $\mathrm{m}^{2} \mathrm{MJ}^{-1}$; for advanced bioethanol from maize stover this is $0.18 \mathrm{~m}^{2} \mathrm{MJ}^{-1}$ (Fig. 4.6). The difference is explained by the higher bioethanol yield from maize stover per ha. Ireland has the smallest land footprint per unit of net bioethanol from wheat straw $\left(0.14 \mathrm{~m}^{2} \mathrm{MJ}^{-1}\right)$, while Cyprus has the largest $\left(0.69 \mathrm{~m}^{2} \mathrm{MJ}^{-1}\right)$. For bioethanol from maize stover, the largest land footprint is in the UK $\left(0.27 \mathrm{~m}^{2} \mathrm{MJ}^{-1}\right)$, and the smallest in France $\left(0.11 \mathrm{~m}^{2} \mathrm{MJ}^{-1}\right)$. The land footprint of advanced bioethanol is larger than the land footprint of first-generation bioethanol from sugar beet or sugarcane $\left(0.07 \mathrm{~m}^{2} \mathrm{MJ}^{-1}\right)$, but smaller than the land footprint of first-generation bioethanol from maize $\left(0.34 \mathrm{~m}^{2} \mathrm{MJ}^{-1}\right)$ (Holmatov et al., 2019). 


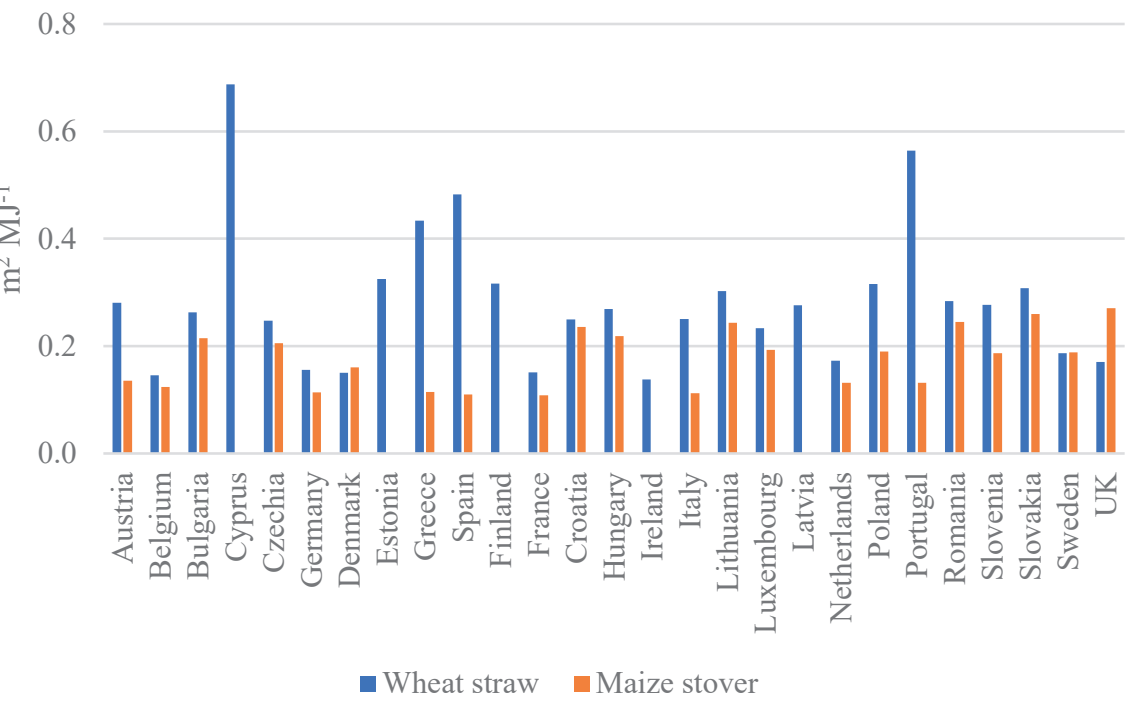

Fig. 4.6. Land footprint per MJ of net advanced bioethanol from wheat straw and maize stover per EU country.

\subsubsection{Water footprint of advanced bioethanol}

The average total water footprint per unit of net bioethanol output in the EU is $173 \mathrm{~L} \mathrm{MJ}^{-1}$ for bioethanol from wheat straw and $113 \mathrm{~L} \mathrm{MJ}^{-1}$ for bioethanol from maize stover. Most of the total water footprint is made up of green water. Across EU, blue water on average contributes less than $1 \%$ to the total water footprint for bioethanol from wheat straw (median $0.22 \%$ ) and $8.9 \%$ for bioethanol from maize stover (median $0.64 \%$ ). Maize is mostly irrigated in the Southern European countries and the share of blue water footprint in Greece and Spain reaches $44-45 \%$ and in the case of Portugal 55\%. In contrast, wheat is mostly rainfed, with the highest share of blue water footprint in Cyprus, reaching 6.3\%.

The average water footprint of net advanced bioethanol from maize stover is almost half the water footprint of first-generation bioethanol from maize (113 vs $235 \mathrm{~L} \mathrm{MJ}^{-1}$ ) (Holmatov et al., 2019). However, there is a large variation of the water footprint of advanced bioethanol between countries (Fig. 4.7), where the water footprint of advanced bioethanol exceeds the water footprint of conventional bioethanol in some countries. For example, the largest water footprint per unit of bioethanol from wheat straw is in Portugal (488 L MJ-1), that is mostly (84\%) green water. The largest water footprint per unit of bioethanol from maize stover is in Lithuania (462 L MJ-1), mostly $(50 \%)$ composed of grey water. 


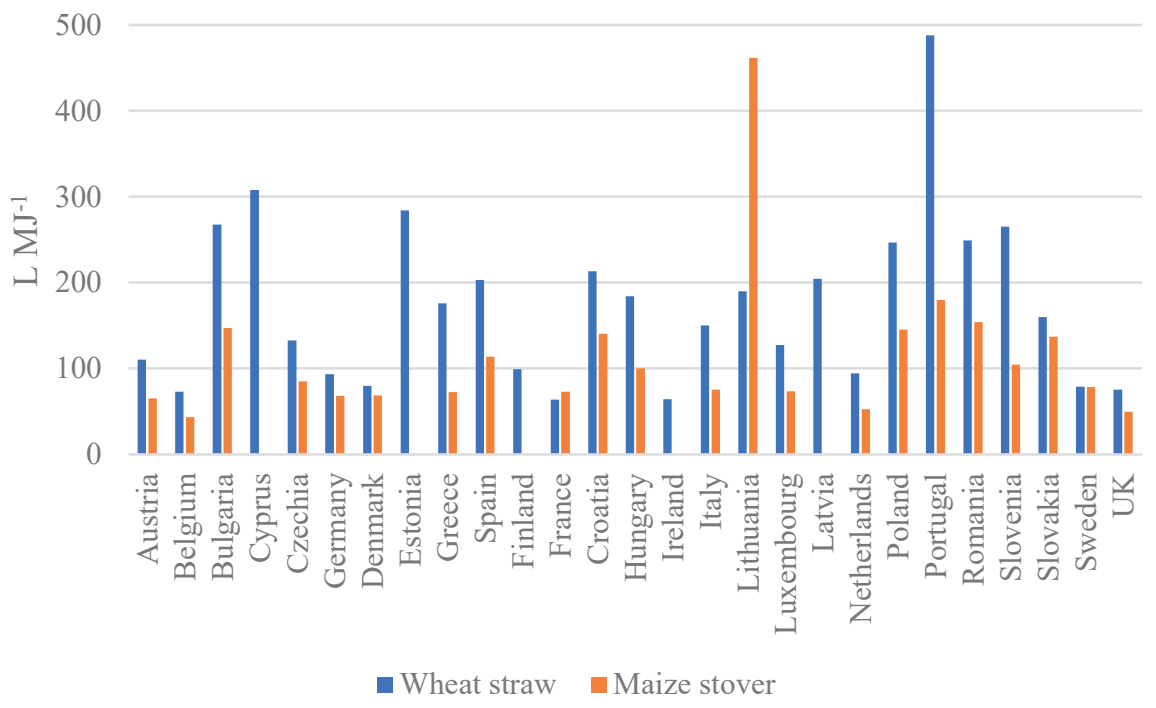

Fig. 4.7. Water footprint per MJ of net advanced bioethanol from wheat straw and maize stover per EU country.

\subsubsection{Carbon footprint of advanced bioethanol}

The average carbon footprints per unit of net advanced bioethanol from wheat straw and maize stover in the EU are 19.4 and $19.6 \mathrm{~g} \mathrm{CO}_{2} \mathrm{eq} \mathrm{MJ}^{-1}$, respectively. There are, however, large variations between countries (Fig. 4.8). For example, the carbon footprint of net bioethanol from wheat straw is highest in Cyprus (41.4 $\left.\mathrm{g} \mathrm{CO}_{2} \mathrm{eq} \mathrm{MJ}^{-1}\right)$ and lowest in Ireland (11 $\mathrm{g} \mathrm{CO}_{2}$ eq $\mathrm{MJ}^{-1}$ ). The carbon footprint of net bioethanol from maize stover is highest in the UK (27.4 $\mathrm{g} \mathrm{CO}_{2} \mathrm{eq} \mathrm{MJ}^{-1}$ ) and lowest in Germany (13.3 $\mathrm{g} \mathrm{CO}_{2}$ eq $\left.\mathrm{MJ}^{-1}\right)$. 


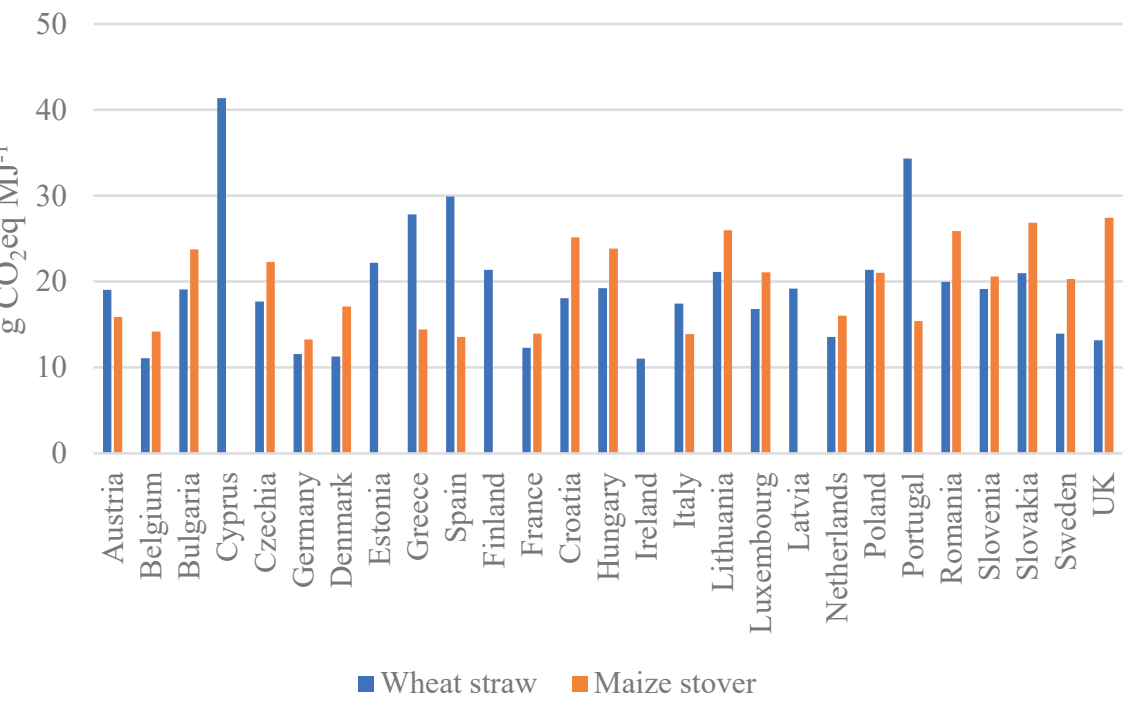

Fig. 4.8. Carbon footprint per MJ of net advanced bioethanol from wheat straw and maize stover per EU country.

Regardless of the country of production, the carbon footprint of advanced bioethanol is much lower than the carbon footprint of gasoline or diesel (72-73 $\mathrm{g} \mathrm{MJ}^{-1}$ ) (Zijlema, 2018). Compared to the carbon footprint per unit of net first-generation bioethanol, the carbon footprint of advanced bioethanol can be equal, higher or lower, depending on the feedstock used to produce conventional bioethanol (Table 4.3).

Table 4.3. Carbon footprint of conventional bioethanol per unit of net energy ( $\mathrm{g} \mathrm{CO}_{2} \mathrm{eq}$ $\mathrm{MJ}^{-1}$ ). Adopted from Holmatov et al. (2019).

\begin{tabular}{|cccc|}
\hline Feedstock & Sugar beet & Sugarcane & Maize \\
Carbon footprint & 19 & 14 & 82 \\
\hline
\end{tabular}

\subsection{Discussion}

\subsubsection{Advanced bioethanol can contribute to emission savings but may have adverse implications}

The carbon footprints of advanced bioethanol from wheat straw and maize stover calculated in this study are much smaller than the carbon footprints of conventional gasoline or diesel. Thus, replacing conventional gasoline and diesel in the transport sector with advanced bioethanol can lead to large emission savings. Potential savings are achieved by using the maximum sustainable harvest of residues; this study assumes that $40 \%$ of wheat straw and $50 \%$ of maize stover can be sustainably harvested, which is probably optimistic. Factors that determine actual sustainable harvest rates depend on location (climate and soil), slope (Gregg \& Izaurralde, 2010), management style, soil type, 
and yield (Andrews, 2006). A 2010 study by the IEA assumed that the sustainable harvest rate of residues for biofuel production is in the range of 10-25\% (Eisentraut, 2010).

Miscalculation of the sustainable harvest rate and excessive removal of crop residues can lead to adverse effects, from soil erosion and organic matter/nutrient removal (Andrews, 2006; Gregg \& Izaurralde, 2010; Wilhelm et al., 2004) to heightening emission of GHGs (Lal, 2005). Moreover, removal of residues can compete with traditional uses of residues (i.e. fodder, bedding, etc.) and raise residue prices, which will affect current residue users (Eisentraut, 2010). Farmers may likely have to apply additional fertilizer due to nutrient losses that come along with residue removal.

\subsubsection{Advanced bioethanol production has a long way to go to catch up with policy targets}

Results of this study show that utilizing all of the sustainably available wheat and maize residues in the EU to produce gross advanced bioethanol can replace $3.44 \%$ of the energy needs of EU's transport sector. EU's renewable energy policy sets a minimum target of $3.5 \%$ from advanced biofuel/biogas in the transport sector's final energy use by 2030 . Despite the growing use of biofuels in the transport sector, EU's total bioethanol production (conventional and advanced) was only 5.85 billion liters in 2017, while the share of advanced bioethanol production in 2017 was only 250 million liters (5.593 PJ) (ePure, 2017). Considering that the transport biofuels are forecasted to grow by $0.5 \%$ between 2019-2024 (IEA, 2019g), some serious breakthrough in advanced biofuel production is required to reach the minimum target of $3.5 \%$ or 22.5 billion liters (479 PJ) of gross bioethanol by 2030 .

\subsection{Conclusion}

This paper assessed the EU's advanced bioethanol production potential and evaluated the land, water and carbon footprint of this sort of bioethanol. The advanced bioethanol production potential in the EU was assessed per member state using country-specific wheat straw and maize stover production data. We differentiated between gross and net advanced bioethanol output, in the latter case subtracting the fuel input equivalent energy from the gross bioethanol output. This is a first-of-a-kind attempt to estimate advanced bioethanol production in the EU and its member states. Moreover, we compare the estimated land, water and carbon footprints of advanced bioethanol with the footprints of conventional bioethanol. These findings lead to two major conclusions. First, the environmental footprint of advanced bioethanol from wheat straw and maize stover is not necessarily smaller than the environmental footprint of conventional bioethanol. Second, current and forecasted advanced bioethanol production is not on track to provide a significant contribution towards achieving the minimum policy target of $3.5 \%$ by the year 2030.

The environmental footprints of advanced bioethanol calculated in this study vary greatly between EU countries. Since the environmental footprints of conventional bioethanol also vary depending on the feedstock used, it is difficult to compare the environmental 
footprints of conventional and advanced bioethanol without specifying the country of production for the advanced bioethanol and the feedstock for the conventional bioethanol. Average land, water and carbon footprints of EU's advanced bioethanol from maize stover are smaller than the respective footprints of conventional bioethanol from maize. In contrast, average land, water and carbon footprints of advanced bioethanol from wheat straw are larger than the respective footprints of conventional bioethanol from sugar beet or sugarcane.

At current rates, advanced bioethanol production from crop residue is not likely to provide a significant contribution towards achieving a minimum policy target of $3.5 \%$ by 2030. The best solution would be to reduce our energy use in the transport sector and utilize other renewable fuels and electricity to significantly lower transport-related emissions. Moreover, advanced bioethanol production can lead to emission savings but may also have adverse effects like increased soil erosion and degradation. Hasty decisions in promoting advanced bioethanol production without understanding and addressing different production-related challenges can leave us in a situation where we have more problems than we anticipated. 


\title{
5. Biofuels for transport: global lignocellulosic bioethanol production potential and its environmental - land, water and carbon footprint
}

\begin{abstract}
Bioethanol production from non-crop based lignocellulosic material has reached the commercial scale and is advocated as a possible solution to decarbonize the transport sector. This study evaluates how much transport related fossil fuel can be replaced with lignocellulosic bioethanol using crop residues, calculates GHG emission savings, and determines lignocellulosic bioethanol's land and water footprints. We estimate global bioethanol production potential from 123 crop residues in 192 countries and 20 territories under different environmental constraints (optimistic and realistic sustainable potentials) versus no constraints (theoretical potential) on residue availability. Previous studies on global bioethanol production potential from lignocellulosic material focused on one or a few biomass feedstocks, and excluded (un)constrained residue availability scenarios. We also assess the environmental footprint family of lignocellulosic bioethanol at an unprecedented level of disaggregation. Results suggest the global net lignocellulosic bioethanol output ranges from 7.1 - 34.0 EJ per annum replacing between 7 and 31\% of oil products for transport yielding a relative emission savings of $338 \mathrm{Mt}(70 \%)$ to $1836 \mathrm{Mt}$ (79\%). Emission savings range from $4 \%$ to $23 \%$ of total transport emissions in the realistic sustainable versus theoretical potential. Land, water and carbon footprints of net bioethanol vary by constraints, countries/territories, and feedstocks, but overall exceed footprints of conventional bioethanol. Averaged footprints range between 1.3-6.7 $\mathrm{m}^{2}$ land $\mathrm{MJ}^{-1}$, 74.3-119.8 $\mathrm{L}_{\text {water }} \mathrm{MJ}^{-1}$, and 28.4-44.4 $\mathrm{g} \mathrm{CO}_{2} \mathrm{eq} \mathrm{MJ}^{-1}$, with smaller footprints in the theoretical compared to sustainable potentials caused by the exclusion of secondary residues and low price of alternative biomass chains in the sustainable potential.
\end{abstract}

\subsection{Introduction}

The climate as we know it is changing linked to the cumulative emission of greenhouse gases (GHGs) from human activities (Pachauri et al., 2014). The energy sector is responsible for about 74\% of global anthropogenic GHG emissions (in 2017) (IEA, 2019a). Energy-related global $\mathrm{CO}_{2}$ emissions reached around 33 gigatonnes in 2019 which was 10 gigatonnes more than in 2000 (IEA, 2020c). Therefore, climate policies prioritize actions to reduce energy related emissions with transition to renewable energy, defined as any form of energy obtained from biological, solar or geophysical sources that is replenishable at a rate exceeding or matching its rate of use (Edenhofer et al., 2011). In 2017, the share of renewables was almost $14 \%$ of the world's total primary energy supply with bioenergy responsible for $68 \%$ of renewables (IEA, 2019f).

Bioenergy is energy derived from various biomass feedstocks (Edenhofer et al., 2011). Biomass can be a biological material generated from recently living or living organisms (Rogner et al., 2012). Compared to the variable renewable sources such as solar and wind technologies, bioenergy is more reliable and easier to dispatch when needed (Edenhofer 
et al., 2011; Rose et al., 2014), because unlike solar and wind energy it can be stored like fossil energy sources. Most of today's bioenergy is in the form of traditional bioenergy, i.e. solid biofuels/charcoal that is used for residential heating and cooking in developing countries (IEA, 2019f). In western countries, bioenergy in the liquid and gaseous form is more valuable as it can substitute, among other things, for conventional transport fuels (Nonhebel, 2005) that are responsible for a quarter of global GHG emissions from fuel combustion (IEA, 2019a).

Liquid biofuels are promoted as low carbon alternative fuels that can help decarbonize the transport sector. Liquid biofuels include different generations. First generation or conventional biofuels are produced mainly from food crops (Eisentraut, 2010; Sims et al., 2010) or their substrates such as sugar, vegetable oils, seeds, starch, grains, etc. (Bharathiraja et al., 2017). Second generation biofuels are produced from non-food biomass (i.e., lignocellulosic feedstock like bioenergy crops, residues and wastes) (Bharathiraja et al., 2017; Rastogi \& Shrivastava, 2017; Sims et al., 2010). Third generation biofuels are produced from algae (Gerbens-Leenes et al., 2014) while fourth generation can be electrofuels and photobiological solar fuels (Rastogi \& Shrivastava, 2017). Often, non-conventional biofuels are simply referred to as advanced biofuels (IRENA, 2016a; Oh et al., 2018). Advanced biofuels production is favored over conventional biofuels because conventional liquid biofuels production entails large water (Dominguez-Faus et al., 2009; Gerbens-Leenes et al., 2009b) and land(Holmatov et al., 2019; Rulli et al., 2016) requirements, competes with food production and can affect food prices (Dornburg et al., 2010; Elbehri et al., 2013; Gupta \& Verma, 2015; López-Bellido et al., 2014; Menon \& Rao, 2012; Sims, 2008). Advanced liquid biofuels produced from non-edible feedstock can avoid issues associated with conventional biofuels (Eisentraut, 2010; IRENA, 2016a; Searle \& Malins, 2016; Sims, 2008), making advanced liquid biofuels produced from residues and wastes an attractive option.

In theory, a diverse range of transport biofuels, from jet fuel to hydrogen is possible (Karatzos et al., 2014). However, the practical advanced biofuel production is currently limited (IEA, 2018b, 2019b; Lynd et al., 2017; Warner et al., 2016). Advanced bioethanol from lignocellulosic feedstock is one of the advanced biofuels that can be currently produced at a commercial scale (IEA, 2018b, 2019c). The forest/agricultural residues are examples of lignocellulosic biomass that are rich in carbohydrates and can be used to produce biofuels (Huzir et al., 2018). Such residues are currently utilized for other purposes; types of competing uses vary spatially and between different sources of biomass (Hiloidhari et al., 2014).

Many studies estimated the global bioenergy resource potentials in terms of primary energy and came to different results based on assumptions, methodologies, datasets, timeframes, etc. One crucial criterion that to a large extent determines the approach and methodology is the type of bioenergy potential that can be differentiated into theoretical, technical, sustainable, market, etc., based on the nature of restrictions that limits bioenergy availability (Batidzirai et al., 2012). For instance, IIASA's Global Energy Assessment estimates the current theoretical global bioenergy potential, that is all of the aboveground 
net primary production (NPP), and puts the estimate at $1126 \mathrm{EJ} / \mathrm{year}$ and the practical potential (excluding NPP used for fiber, feed, and food) at 793 EJ/year based on gross calorific value (Rogner et al., 2012). Fischer and Schrattenholzer (2001) estimated the economic bioenergy potential (based on economic criteria) in 2050 and put the number at 350-450 EJ. The latter included crop residues, forest products, grassland biomass, animal and municipal wastes. Beringer et al. (2011) estimated global bioenergy potential in 2050 under different land availability scenarios and reported the range as $130-270$ EJ from all biomass source combinations. Searle and Malins (2015) estimated the sustainable bioenergy potential in 2050 (from dedicated energy crops, forestry residues, crop residues and wastes) and put the number at 60-120 EJ/year as primary energy. A decreasing availability is reported in these studies going from theoretical to other types of potentials and temporal decline in availability caused by land use changes (Beringer et al., 2011; Fischer \& Schrattenholzer, 2001; Searle \& Malins, 2015) (e.g., increasing area of cultivated land to meet food demand of a growing population).

Some studies estimated global bioenergy potential in terms of energy carriers such as liquid biofuels. Davis et al. (2011) reported the sustainable bioethanol production potential using lignocellulosic biomass from agave and concluded that 6.1 billion liters of bioethanol can be produced annually. Abbas \& Ansumali (2010) estimated the theoretical bioethanol potential from rice husk and reported the range of $20.9-24.3$ billion liters per annum. However, no study has looked at the global total liquid biofuel/bioethanol theoretical and sustainable potentials per crop residue and across countries. To inform the energy transition discourse, it is relevant to evaluate the total theoretical liquid biofuel potential, the sustainable potential, and to determine the environmental footprint family (land, water, and carbon) of liquid biofuel per crop residue and across countries.

The environmental footprint family is an umbrella term that encompasses different footprint concepts (Fang et al., 2014; Galli et al., 2012; Hoekstra \& Wiedmann, 2014; Davy Vanham et al., 2019). In this study, by environmental footprint family we consider the land, water and carbon footprints. Environmental footprints serve as indicators of the pressure of an activity or a product on the environment and help to explain impacts of this pressure (Hoekstra \& Wiedmann, 2014). A single footprint indicator focuses on a particular environmental concern (Hoekstra \& Wiedmann, 2014), but a footprint family composed of two or more individual footprints can help assess broader environmental impacts by complementing each other (Fang et al., 2014; Galli et al., 2012; Davy Vanham et al., 2019). Only few studies have assessed a combination of two or more footprints of conventional (Holmatov et al., 2019) and advanced biofuels (Gerbens-Leenes et al., 2014), but the footprint assessment of advanced biofuels for theoretical versus sustainable potential, across countries and for different feedstocks is missing.

This study evaluates how much of the transport related fossil fuels can be replaced with lignocellulosic bioethanol using crop residues, calculates the scale of GHG emission savings that this replacement can bring, and determines land and water resources that are required for producing the lignocellulosic bioethanol per crop and country. Specific steps to accomplish this objective are (1) to estimate the global lignocellulosic bioethanol production potential from agricultural residues with and without setting residue availability restrictions; and (2) assess the environmental footprint (i.e., land, water, and 
carbon) of a residue-based bioethanol per crop, country and estimated potential. The results can help us evaluate and compare the GHG emission factor of lignocellulosic bioethanol for different crop residues and across different countries while also comparing their sustainability from the land and water perspectives.

\subsection{Methods}

\subsubsection{Overview of bioethanol production}

Production of bioethanol can be divided into the agriculture phase and the conversion phase (Figure 1). The agriculture phase generates two types of biomass outputs at the site: (1) the economic yield, and (2) primary residue. In addition, the processing of the economic yield can generate a secondary residue off-site (i.e. food processing, fiber crop byproducts) and for simplicity of presentation, it is added to the agriculture phase. Examples of primary and secondary residues are summarized in Table 5.1. This study focuses on the primary agricultural residue (generated in the field during harvesting) as well as the secondary residue (generated at the processing sites) but excludes the tertiary residue (post-consumer residues) (Eisentraut, 2010). The two main reasons for excluding the tertiary residue are: (i) lack of reliable data as the amount of organic waste depends on variables like the consumption pattern, and economic development (Hoogwijk et al., 2003); and (ii) that many regional and country policies aim to minimize food losses (i.e., tertiary residues) and organic waste is progressively being collected to convert to compost.

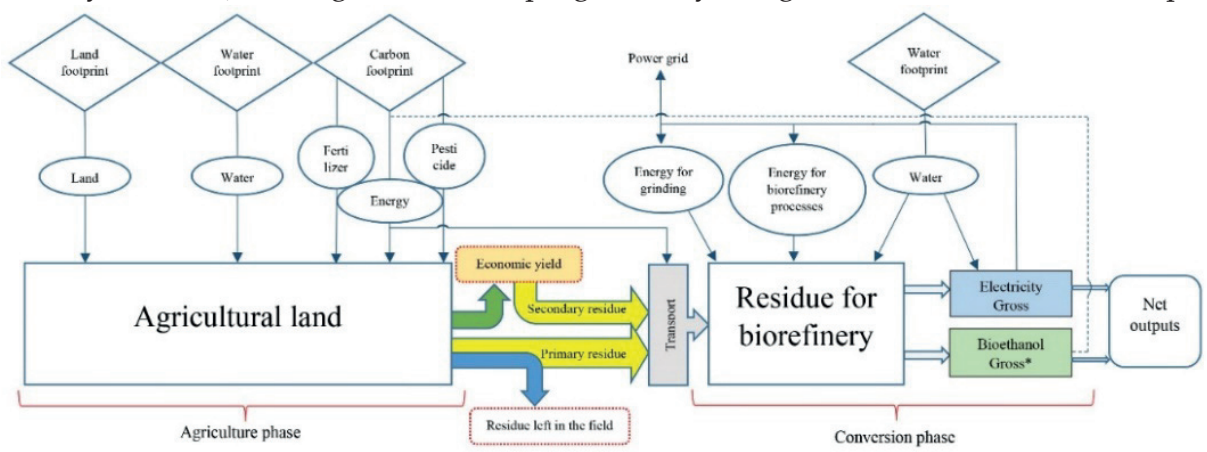

Fig. 5.1. Schematization of lignocellulosic bioethanol production. Note: * Gross to net distinction is shown to clarify energy balance but has no effect on the carbon footprint calculations.

The conversion phase is assumed to generate two types of outputs: (1) bioethanol, and (2) electricity. Co-produced electricity is counted as output only if it is in excess of electricity required to satisfy biorefineries' own needs. This surplus electricity can be sold to the grid (Humbird et al., 2011) and as such becomes an economically valued by-product of the biorefinery process. 
Table 5.1. Primary and secondary residue examples for different plant categories. Compiled using data from TARA (Nd), Ryan \& Openshaw (1991), Koopmans \& Koppejan (1997), Jölli \& Giljum (2005), Offermann et al. (2011), Zafar (2018), and Vassilev et al. (2010).

\begin{tabular}{|lll|}
\hline \multicolumn{1}{|c}{ Plant variety } & \multicolumn{1}{c}{ Primary residue } & \multicolumn{1}{c|}{ Secondary residue } \\
\hline $\begin{array}{l}\text { Field and seed crops (e.g., } \\
\text { cereals, sugar crops, roots } \\
\text { and tubers, pulses, } \\
\text { temporary oil and fiber } \\
\text { crops, etc.) }\end{array}$ & $\begin{array}{l}\text { Leaves, pods, stalks, } \\
\text { straw, stems, tops }\end{array}$ & $\begin{array}{l}\text { Bran, cob, husk, molasses, } \\
\text { bagasse, pomace, shell, } \\
\text { peelings, presscake }\end{array}$ \\
\hline $\begin{array}{l}\text { Vegetable crops (e.g., cabbages, } \\
\text { green beans, tomatoes, } \\
\text { carrots, etc.) }\end{array}$ & $\begin{array}{l}\text { Foliage, leaves, } \\
\text { shoots, stems }\end{array}$ & Peelings, pods \\
\hline $\begin{array}{l}\text { Orchard and vineyard crops } \\
\text { (e.g., fruits, nuts, grapes, } \\
\text { gooseberries, etc.) }\end{array}$ & $\begin{array}{l}\text { Pruning, fronds, } \\
\text { stems, shoots, leaves, } \\
\text { old plants }\end{array}$ & $\begin{array}{l}\text { Fiber, shells, bunches, copra, } \\
\text { pulp, peelings, rind, sepal, } \\
\text { tops, husks, fruit stems }\end{array}$ \\
\hline
\end{tabular}

Availability of secondary residue for bioethanol is relatively more difficult to assess than the primary residue. Technical, economic and environmental factors (Fischer, 2007), such as the difficulty assessing the fraction that has existing uses (Eisentraut, 2010; OECD, 2004; Okello et al., 2013; Shyam, 2002) (i.e., corncobs are already used to produce chemical materials or rural energy while the fraction of rice husk and bagasse is already used for power generation), and complexity of logistical constraints of transporting them to biorefineries (Bioenergy Europe, 2018) are some of the obvious reasons. Even so, the secondary residues can play an important role because they are concentrated at a specific location, avoid issues with disposal (Okello et al., 2013), and have a stable year-round supply (Eisentraut, 2010).

\subsubsection{Theoretical potential vs optimistic sustainable potential vs realistic sustainable potential}

The current study calculates the theoretical, optimistic sustainable, and realistic sustainable bioethanol potentials. The theoretical potential is the least restrictive and assumes that all biomass is available to be used for bioenergy (Bentsen \& Felby, 2012; Edenhofer et al., 2011; Portugal-Pereira et al., 2015) while the optimistic sustainable and realistic sustainable potentials have restrictions on the amount of biomass collection considering the technical and environmental implications (Batidzirai et al., 2012; Bentsen \& Felby, 2012). Technical restrictions relate to the current technical possibilities taking into account competition with existing land uses (e.g., feed, food, and fibre) (Batidzirai et al., 2012; Bentsen \& Felby, 2012), while the environmental restrictions relate to mitigating adverse impacts on water, soil or biodiversity (Batidzirai et al., 2012; Portugal-Pereira et al., 2015).

Theoretical potential assumes complete collection of the primary (aboveground residue) and secondary residue. The optimistic sustainable potential assumes the residue availability is limited to $50 \%$. The realistic sustainable potential assumes the residue 
availability is limited to $25 \%$. Residues generated from orchards are assumed noncompetitive and the availability is constant across scenarios.

The range of residue availability in the sustainable potential variants is in line with previous studies (Table D1, Annex D). Breakdown of proportion of residue remaining in the field due to environmental vs technical considerations are $30 \%$ and $20 \%$ in the optimistic sustainable potential, and $50 \%$ and $25 \%$ in the realistic sustainable potential, respectively.

Secondary residue (i.e., bran or hulls from cereals; molasses from sugar crops; bran from pulses; shells from nuts; cake from oilseeds; fruit pulp from fruits) is estimated for crops with reported conversion factors by FAO $(\mathrm{Nd})$. All secondary residue is assumed as available for bioethanol production in the theoretical bioethanol potential estimation, but is assumed as unavailable under the sustainable potential restrictions because of competition with existing uses and logistical constraints.

\subsubsection{Environmental footprint calculations overview}

Land, water, and carbon footprints are frequently used environmental footprints and together form the environmental footprint family (Fang et al., 2014; Galli et al., 2012) (although it can include other footprints (Davy Vanham et al., 2019) which are not included in this study). Land footprint refers to appropriation of land as a resource (Hoekstra \& Wiedmann, 2014). Water footprint refers to consumptive freshwater appropriation in the supply chain of a product or an activity and includes three components: a blue component (consumption of surface and groundwater), a green component (consumption of precipitation water), and a grey component (water required to assimilate pollution to accepted water quality standards) (Hoekstra et al., 2011). Carbon footprint refers to supply chain GHG emissions of a product (Hoekstra \& Wiedmann, 2014). Calculation boundaries for individual footprints assumed in this study are presented in Figure 5.2.

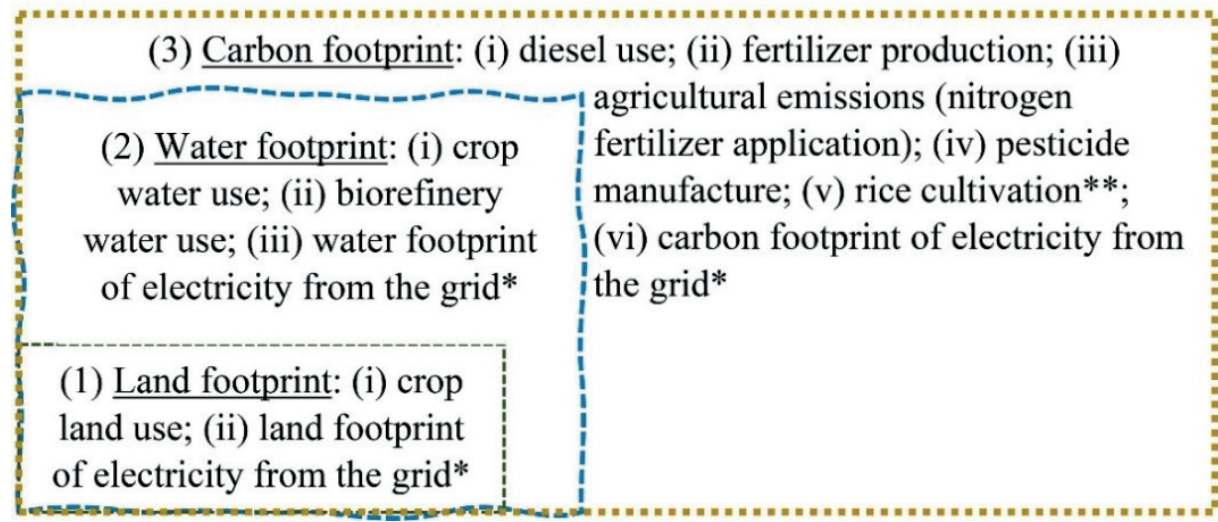

Fig. 5.2. Calculation boundaries for land, water, and carbon footprint assumed in this study. Notes: ${ }^{*}$ Refers to indirect footprints linked to electricity from the grid for crops with insufficient cogenerated electricity; ${ }^{* *}$ Specific to rice.

Environmental footprints per unit of bioethanol's stored net energy are calculated in five steps. The first step calculates water, energy and carbon $\left(\mathrm{CO}_{2} \mathrm{eq}\right.$ emissions) intensity of 
inputs. The second step calculates gross bioethanol and gross electricity production per crop, and per country. The third step determines the value fraction of bioethanol compared to the outputs of agriculture and conversion phases. The fourth step calculates the net bioethanol output by subtracting energy equivalents embedded in inputs during the agriculture phase from the gross bioethanol's stored energy. The fifth step calculates the land, water, and carbon footprints per bioethanol's stored net energy per crop, and per country.

\subsubsection{Step one - resource inputs}

The environmental footprint family related categories of inputs are summarized in Table D2 (Annex D). The land footprint of bioethanol production is linked to: (1) agricultural land use and (2) land footprint of the power grid. The crop harvested area from FAOSTAT (2020) is used as the basis of the agricultural land use. The land footprint of the power grid is calculated by multiplying the land footprint of electricity generated from a particular source (except for the ambiguous "other renewables" category) (Trainor et al., 2016) by its percent contribution to the global electricity generation mix in 2018 (IEA, 2019d) and summing the results. The "other renewables" category is assumed as a mix of geothermal, solar thermal, and biomass. The land footprint of "other renewables" is calculated as the average footprint of its composites.

The water footprint of bioethanol is linked to: (1) crop water use; (2) biorefinery water use; and (3) water footprint of electricity (from the power grid). Ten year average crop water use data is obtained from Mekonnen \& Hoekstra (2011), and consists of blue, green, and grey components. Water use in biorefinery refers to evaporative losses (Humbird et al., 2011) of blue water. The water footprint of the power grid is calculated by multiplying the median net water footprint of electricity generated from a particular energy source (Mekonnen et al., 2015) by its percent contribution to the global electricity generation mix in 2018 (IEA, 2019d) and summing the results. The water footprint of "other renewables" is calculated as the median of the average water footprints of its composites.

The carbon footprint of bioethanol is linked to (1) diesel use; (2) fertilizer production; (3) agricultural emissions related to synthetic (nitrogen) fertilizer application; (4) pesticide manufacture; (5) rice cultivation (only applicable to rice that emits methane gas during growth); and (6) the power grid. Diesel use for ploughing $(21 \mathrm{~cm})$, sowing, fertilizing pesticide spraying, mowing (the residue), bailing and handling (the residue) (Dalgaard et al., 2001) is converted to the energy equivalent using the lower heating value of diesel calculated from IEA \& OECD (2010) and then to CO2eq emissions using diesel fuel's emission factor (Zijlema, 2018). Diesel is also used to transport residues and, consistent with previous studies (Bang et al., 2013; Monforti et al., 2015; Portugal-Pereira et al., 2015; Spöttle M., 2013), the transportation distance is limited to $50 \mathrm{~km}$ from field to biorefinery, where increasing distance can lead to higher transportation costs and GHG emissions (IEA, 2020a). Considering the complexity of interaction between the dry matter, moisture content, truck payload constraints and bulk and solid density (Sosa et al., 2015), two different transportation energy requirements (MJ tonne $\mathrm{e}^{-1}$ ) are assumed for primary vs secondary residues (Edwards et al., 2017). The moisture content is an important factor that can affect transport, handling and processing, and residue storage (Nagata et al., 
2020). The carbon footprint of transportation is calculated by multiplying available primary and secondary residue fresh weight (calculated in Step 2 below) by their respective energy requirements assuming a distance of $50 \mathrm{~km}$ and using diesel's emission factor.

Carbon emissions from fertilizer production are calculated as the product of a five year averaged nutrient nitrogen applied in a specific country (FAOSTAT, 2020) and the average $\mathrm{CO}_{2}$ eq emissions (for ammonium nitrate, calcium ammonium nitrate, ammonium nitrosulphate, and calcium nitrate) per weight of a product at the plant gate (Fertilizers Europe, 2019). Agricultural emissions (direct and indirect nitrous oxide) related to nitrogen fertilizer application are calculated using the tier 1 methodology (Tubiello et al., 2015) where the nitrogen input is a five year averaged nutrient nitrogen applied in a specific country (FAOSTAT, 2020). Results are converted to $\mathrm{CO}_{2} \mathrm{eq}$ using the 100 year global warming potential of nitrous oxide (Pachauri et al., 2014). The carbon footprint of pesticide manufacturing is calculated as a product of the weighted average pesticide manufacturing energy with the related emission factor from Audsley et al. (2009) and the five year average pesticide application rate in a given country (FAOSTAT, 2020). To calculate the emission from rice cultivation, the FAOSTAT (2020) implied emission factor of $140 \mathrm{~kg} \mathrm{CH}_{4} \mathrm{ha}^{-1}$ is multiplied by the crop harvested area.

Country specific, nationwide grid emission factors for 94 countries are compiled from IGES (2020), Koffi et al. (2017), and OECD (2015). For countries with missing emission factors, a global average emission factor was calculated across the 94 countries and used instead. Electricity is used for grinding wet residues and for biorefinery processes. Particle size is a key parameter influencing cellulose hydrolysis potential (Zoghlami \& Paës, 2019). The study adopted energy required for grinding to the size of $0.5 \mathrm{~mm}$ at the biorefinery from German \& Bauen (2018) Electricity use in a biorefinery is linked to the bioethanol production and consistent with a previous report (Humbird et al., 2011) assumed 1.03 $\mathrm{kWh}$ per liter of ethanol.

\subsubsection{Step two - gross bioethanol and gross electricity production}

Gross bioethanol production, BE (tonnes), depends on: (a) the amount of residue (dry weight); (b) cellulose and hemicellulose content of a particular residue; (c) cellulose and hemicellulose conversion and recovery efficiencies; (d) ethanol stoichiometric yield per unit of mass; and (d) glucose and xylose fermentation efficiencies as:

$B E=R \times C a r b \times C R_{\text {eff }} \times S Y_{B E} \times F_{\text {eff }}$

where $R$ is dry residue in tonnes; Carb refers to residue cellulose/hemicellulose content $(\%) ; C R_{e f f}$ is the conversion and recovery efficiency of cellulose/hemicellulose from Table $5.2(\%) ; S Y_{B E}$ is the stoichiometric ethanol yield per unit of sugar; and $F_{\text {eff }}$ is the fermentation efficiency of glucose and xylose sugars (\%). Table 5.2 shows the residue to gross bioethanol conversion calculation parameters from Badger (2002). 
Table 5.2. Residue to gross bioethanol conversion calculation parameters. Source: Badger (2002).

\begin{tabular}{|c|c|c|c|c|c|}
\hline Carbohydrate & Content & $\begin{array}{l}\text { Conversion } \\
\text { and } \\
\text { recovery } \\
\text { efficiency }\end{array}$ & $\begin{array}{c}\text { Glucose } \\
\text { fermentation } \\
\text { efficiency }\end{array}$ & $\begin{array}{c}\text { Xylose } \\
\text { fermentation } \\
\text { efficiency }\end{array}$ & $\begin{array}{c}\text { Ethanol } \\
\text { stoichiometric } \\
\text { yield }\end{array}$ \\
\hline Cellulose & \multirow{2}{*}{$\begin{array}{c}\text { Varies } \\
\text { (Table } \\
\text { D3) }\end{array}$} & 0.76 & 0.75 & & \multirow{2}{*}{0.51} \\
\hline Hemicellulose & & 0.96 & & 0.5 & \\
\hline
\end{tabular}

The key data for calculating the residue availability is the FAOSTAT (2020) database covering 160 primary crops (not all of them are included in this study). For 27 crops (e.g., mushrooms, berries, spices, fiber crops), the residue production ratio (RPR) and residue to surface ratio (RSR) used to determine the amount of residue per crop were not available and therefore these crops were excluded (Table D3, Annex D). RPR refers to a ratio of crop residue to crop main produce (Daioglou et al., 2016; Fischer, 2007) that is used in converting tonnes of crop production to tonnes of residue production (appropriate for field crops that are more homogenous). RSR refers to the ratio of residue to surface area (Daioglou et al., 2016) that is used to convert area of production to tonnes of residue production (appropriate for orchards that are more variable). Further 10 crops were excluded from the analysis due to the absence of price data, bringing the final number of crop specific residues utilized in this study to 123, spanning an area across 192 countries and 20 territories (territory here is used in a broad sense to refer to areas that are not fully independent states or are disputed regardless of the legal status, i.e., overseas region, department, collectivity, etc.). The area covered by the crops included in this study envelopes $98.8 \%$ of the total primary crop area reported by FAOSTAT, thus the amount of available residue and the global bioethanol production potential calculated in this study covers most of the global potential.

Residue productions are calculated using (i) RSR compiled from literature for orchards (Table D4, Annex D); (ii) RPR compiled from Fischer et al. (2007), Eisentraut (2010) and Terrapon-Pfaff (2012) for field crops; and (iii) using the FAO (Nd) conversion factors for the production of secondary residue (Table D3, Annex D). Specifically, primary residue for field crops is obtained by multiplying the five year average primary crop production data from FAOSTAT (2020) by the crop specific RPR. Primary residue for orchards is obtained by multiplying the five year average crop harvested area data from FAOSTAT (2020) by their respective RSR values compiled from literature (Beer, 1988; Bilandzija et al., 2012; CIRCE, 2014; Di Giacomo \& Taglieri, 2009; Fernandes \& Costa, 2010; GarcíaGalindo et al., 2019; Grella et al., 2013; Hengsdijk, 2018; Hosseinkhani et al., 2014; Koopmans \& Koppejan, 1997; Magagnotti et al., 2013; Milbrandt, 2009; Nati et al., 2018; Pari et al., 2018; Rentizelas et al., 2009; Spinelli et al., 2010; Spinelli et al., 2012; Unal \& Alibas, 2007; Velázquez-Martí et al., 2011; Velázquez Martí et al., 2013).

Secondary residues are obtained by multiplying the five year average crop production data from FAOSTAT (2020) by the FAO (Nd) conversion factors using the following assumptions. Among different by-products only the by-product of the main production route (i.e., flour production by-product rather than alcohol production by-product of 
wheat processing) is assumed for each of the crops using the world average number when possible (i.e., wheat bran range is $10-26 \%$ while the world average is $18 \%$ ). Conversion factors specifying secondary residue production is reported for 45 of 123 crops utilized in this study.

Moisture content of biomass used at biorefinery can be high (Piccolo \& Bezzo, 2009), but the ethanol yield depends on the dry residue weight. Wet residue is converted to dry weight as:

$D W_{i}=H W_{i} \times D m c_{i}$

where $D W_{i}$ is the dry weight of residue feedstock for crop $i$ (in tonnes); $H W_{i}$ is harvested moisture weight of residue feedstock for crop $i$ (in tonnes); and $D m c_{i}$ is the dry matter content of the harvested residue feedstock for crop $i(\%)$.

Moisture content of primary field residues is obtained from Fischer (2007) and Eisentraut (2010). When a moisture content of orchard residue is not given, the fresh matter of orchard residues is assumed $40 \%$, which is consistent with assumptions in previous studies (CIRCE, 2014; Daioglou et al., 2016; Di Blasi et al., 1997; Rentizelas et al., 2009; Scarlat et al., 2011; Unal \& Alibas, 2007). For ease of calculations, all orchard residues are normalized to $40 \%$ moisture content to calculate energy required for transportation and to $0 \%$ moisture content to calculate bioethanol production using equation 2 . Fresh matter of secondary residue is assumed $15 \%$ with the exception of pulp and molasses. For the latter, reported total soluble sugar yields (\%) (Zabed et al., 2017) are converted to gross ethanol assuming 50\% cellulose specific calculation parameters and 50\% hemicellulose specific calculation parameters.

Cellulose, hemicellulose and lignin are the three major components of lignocellulosic biomass (Liu et al., 2017; Sluiter et al., 2010; Zoghlami \& Paës, 2019). Among the three components, hemicellulose is the easiest to hydrolyse, followed by cellulose (Aditiya et al., 2016; Zoghlami \& Paës, 2019), and both can be converted to sugars through enzymatic or chemical methods (Hendriks \& Zeeman, 2009; Zabed et al., 2017). Crop specific compositions of residue feedstock in primary residues is compiled from the Phyllis2 (2020) database (25 residues), Reddy \& Yang (2005) (1 residue), and Hassan et al. (2018) (1 residue). For the remaining 96 cases an average biomass composition is utilized (Table D3, Annex D). Ratios between cellulose, hemicellulose and lignin can vary based on factors such as the harvesting season, culture conditions, and age (Hassan et al., 2018). The average biomass composition for this study is calculated using data from: Milbrandt and Overend (2008), Menon and Rao (2012) and Redin et al. (2014). Composition of secondary residue feedstock is compiled from the Phyllis2 (2020) database (13 residues), Hassan et al. (2018) (5 residues), Zabed et al. (2017) (6 residues), and for the remaining 21 cases an average biomass composition is utilized.

Electricity co-generation in a biorefinery is calculated using the heat content of postprocessed residue sludge. Specifically, assumed heat of combustions are $7.1 \mathrm{kcal} \mathrm{g}^{-1}(29.7$ MJ kg-1) for lignin, $4.2 \mathrm{kcal} \mathrm{g}^{-1}\left(17.6 \mathrm{MJ} \mathrm{kg}^{-1}\right.$ ) for cellulose (Bisaria \& Ghose, 1981), and 17.0 
MJ kg-1 for hemicellulose (Zhang et al., 2009). The lignin content of residue is assumed to remain intact in the post-processed sludge as it can hinder hydrolysis (Hendriks \& Zeeman, 2009; Huzir et al., 2018; Sims, 2008; Zoghlami \& Paës, 2019) and undesirable for bioethanol production. In addition, considering reported conversion and recovery efficiencies (Table 5.2), $24 \%$ of cellulose and $4 \%$ of hemicellulose is assumed to remain in the post-processed residue sludge. Consistent with Humbird et al. (2011), thermal conversion efficiency of post-processed residue sludge to steam is assumed at $80 \%$, and steam to electricity at $31 \%$, yielding the post-processed sludge to electricity efficiency of $24.8 \%$. Electricity generation is thus calculated as:

$E_{i}=\left(\left(L_{i} \times 29.7\right)+\left(C_{i} \times 17.6\right)+\left(H_{i} \times 17\right)\right) \times 0.248$

Where $E_{i}$ is the electricity output (MJ) from post-processed residue sludge for residue $i ; L_{i}$ is the lignin content $(\mathrm{kg})$ of post-processed residue sludge for residue $i$; $C_{i}$ is the cellulose content $(\mathrm{kg})$ of post-processed residue sludge for residue $i$; and $H_{i}$ is the hemicellulose content $(\mathrm{kg})$ of post-processed residue sludge for residue $i$.

\subsubsection{Step three - value fraction calculations}

The value fraction of bioethanol compared to the total outputs is calculated differently for theoretical vs sustainable potential variants and for different energy inputs (energy used directly for ethanol production vs energy for general agricultural uses). Specifically, the agriculture phase outputs in the theoretical potential are: crop, bioethanol, and electricity. The agriculture phase outputs in the two sustainable potential variants are: crop, bioethanol, electricity, and the alternative biomass delivery chain (e.g., fodder, bedding, construction, mushroom industry, power station) - for non-orchards/vineyard crop residues (orchard and vineyard residues are assumed non-competitive (IEA, 2020a)). When energy is used directly for ethanol production the outputs are bioethanol and electricity while when energy is used for general agricultural activities the outputs are the same as the agriculture phase outputs. The conversion phase outputs are: bioethanol and electricity. The general formula for the value fraction calculation is:

$f_{v}(B E)=\frac{\operatorname{price}(B E) \times w(B E)}{\sum_{p=1}^{3}((\operatorname{price}(p) \times w(p))}$

Where the value fraction of bioethanol is $f_{v}(B E)$, price $(B E)$ is the price of bioethanol (USD/MJ), and $w(B E)$ is the quantity of gross bioethanol (MJ). Denominator is the total value of output products calculated as price times quantity. Five year average crop prices in United States Dollars (USD) per unit of mass are obtained from FAOSTAT (2020). When prices are available only in standard local currency (SLC), they are converted to USD using the exchange rate from FAOSTAT (2020). In the absence of a country specific crop price a global average crop price is calculated and utilized. The price of electricity in USD for individual countries for 2018 is obtained from The World Bank (2020) and when the price for a particular country is not reported a global average price is substituted. The CBOT ethanol price is calculated as average of closing prices in 2018 from Nasdaq (2020). The market price for the alternative biomass delivery chain is uncertain and depends on many factors (i.e., type of residue Gallagher et al. (2003); costs of collection and transport Wageningen University (2013); etc.). Some recent studies such as the FAO and EBRD (2017) had used the residue collection price as the primary indicator of the residue price. 
In this study the price of the alternative biomass delivery chain (price for the actual resource paid to farmers) is assumed to be 6 USD per fresh tonne ${ }^{-1}$, which is in line with 6 euros per tonne ${ }^{-1}$ paid in Europe (Wageningen University, 2013) and 5 USD per ton ${ }^{-1}$ (US ton is 0.91 metric tonne $^{-1}$ ) paid in the USA (O'Brien et al., 2010). Temporal variation in straw prices is assumed irrelevant as a Danish study projected less than a $10 \%$ increase between 2012 and 2022 under three different scenarios (Bang et al., 2013).

\subsubsection{Step four - net bioethanol calculation}

Gross bioethanol output per hectare (MJ ha-1) is converted to net bioethanol output by subtracting the energy embedded in inputs. Specifically, energy embedded in the fertilizer production, pesticide production, energy used directly for ethanol production, energy used for general agricultural activities for residue $i$ in a given country (step 1 above) is multiplied by the value fraction of bioethanol from step three and subtracted from gross bioethanol output for residue $i$ in a given country calculated in step two.

Net electricity output (or net required input from the grid) is calculated by subtracting (i) electricity use in biorefineries and (ii) electricity use for residue grinding from (iii) the gross electricity output (step 2). Specifically, electricity use in biorefineries is calculated by multiplying gross bioethanol output for residue $i$ in a given country by electricity used per volume of gross ethanol (step 1). Electricity use for residue grinding is calculated by multiplying the amount of residue (fresh weight) for residue $i$ (step 2) by $40 \mathrm{kWh}$ tonne $\mathrm{e}^{-1}$. The LHV of ethanol is taken from USDOE (2014). The ethanol density is taken from Humbird et al. (2011).

\subsubsection{Step 5 - environmental footprints, land, water and carbon footprints, per unit of net} bioethanol

The land footprint per unit of net bioethanol is calculated as the sum of the land footprint from the agriculture phase and the land footprint of the grid (if electricity is required from the grid). The land footprint of the agriculture phase is calculated as: the value fraction of gross bioethanol (step two) divided by the net bioethanol output per hectare (step four). The land footprint of electricity from the grid is calculated by dividing the land footprint of net electricity required from the grid by the net ethanol output.

The water footprint per unit of net bioethanol is calculated as the sum of the (i) water input of the agriculture phase multiplied by the value fraction of bioethanol, (ii) water input of the conversion phase multiplied by the value fraction of bioethanol, and (iii) water footprint of the power grid (if required), divided by the net bioethanol output from step four. The value fraction of bioethanol differs between different potentials, crops, countries, and between the agriculture versus the conversion phases (see step three).

The carbon footprint per unit of net bioethanol is calculated in three steps. The first step multiplies the respective emissions by the value fraction of bioethanol. The second step divides each category of emissions by the net bioethanol output. The third step sums the results. Specific categories of emissions are: (i) emissions from using diesel; (ii) emissions from fertilizer production; (iii) agricultural emissions (nitrogen fertilizer application); (iv) emissions from pesticide manufacture; (v) emissions from rice cultivation; and (vi) emissions related to the power grid (if required). 


\subsection{Results}

\subsubsection{Global crop residue, bioethanol and bioelectricity production potentials}

Global total annual net bioethanol production potential from the 123 crop residues calculated in this study ranges from 34 EJ under no restrictions for residue collection (theoretical potential) to $7 \mathrm{EJ}$ when the primary residue collection is restricted to a maximum of $25 \%$ (realistic sustainable potential; Fig. 5.3). Depending on the country conditions and the potential-specific assumptions, not all crop residues can produce positive net bioethanol as the energy inputs for production can exceed the energy output and are not counted in this total. The difference between the gross and net bioethanol output is smaller in the theoretical potential, $9 \%$, than in the optimistic sustainable potential, $11 \%$, and the realistic sustainable potential $13 \%$, reduction. The reason for this is that energy inputs for general agricultural activities remain the same between the theoretical potential and the two sustainable potential variants despite declining bioethanol output (linked to reduced primary residue availability and exclusion of secondary residue for bioethanol production in the sustainable potential) requiring a relatively larger share of the gross bioethanol output to be used in the production processes.

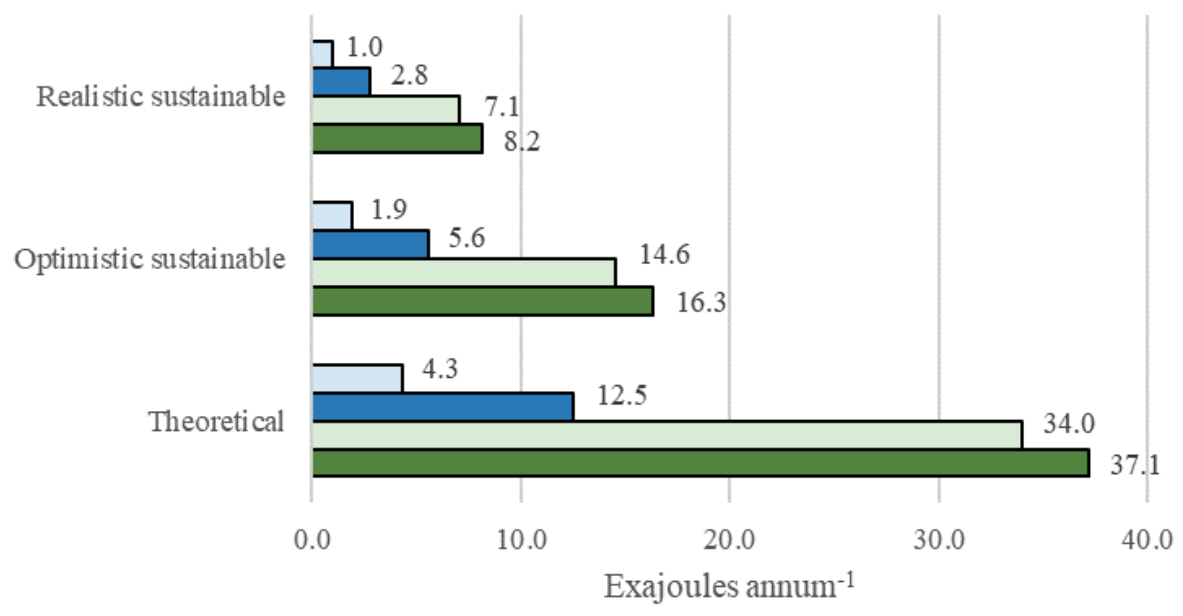

\section{口Electricity Net $\quad$ Electricity Gross $\quad$ EEthanol Net $\mathbf{\square}$ Ethanol Gross}

Fig. 5.3. Total annual global bioethanol and electricity production capacity (EJ year ${ }^{-1}$ ) under three different potential variants.

In practical terms, the global total net bioethanol produced from 123 crop residues can only replace between $7-13 \%$ (realistic sustainable potential and optimistic sustainable potentials, respectively) to $31 \%$ (theoretical potential) of 2,589 Mtoe oil products (i.e., 108 EJ year $^{-1}$ ) (IEA, 2020b) currently consumed in the world's transport sector (2017 numbers). Bioethanol mix with oil products is common, although using a blend of bioethanol with gasoline exceeding $10 \%$ (by volume) can pose infrastructure compatibility issues (Karatzos et al., 2014). 
At the regional level, only Africa could produce enough net bioethanol (at the theoretical potential) from local crop residues to replace oil products consumed in the transport sector (Figure 4). However, in terms of optimistic sustainable or realistic sustainable potentials, Africa can replace $54 \%$ or $26 \%$ of oil products use in Africa's transport sector, respectively. Central \& South America have the second largest capacity in terms of producing net bioethanol from local crop residues to replace its transport sector's demand for oil products, from $83 \%$ at the theoretical potential to $16 \%$ at the realistic sustainable potential. Asia Pacific and Eurasia, are placed in the middle of the regional ranking and can produce net bioethanol that could replace from a high of $46 \%$ and $39 \%$ (theoretical potential) to a likely range of $9 \%$ and $8 \%$ (realistic sustainable potential), respectively. Europe and North America have relatively smaller capacity to replace their demand for oil products as they can replace from a high of $23 \%$ and $19 \%$ (theoretical potential) to a low of $5 \%$ and $4 \%$ (realistic sustainable potential), respectively. The Middle East has the least potential from a high of $5 \%$ (theoretical potential) to a low of $1 \%$.

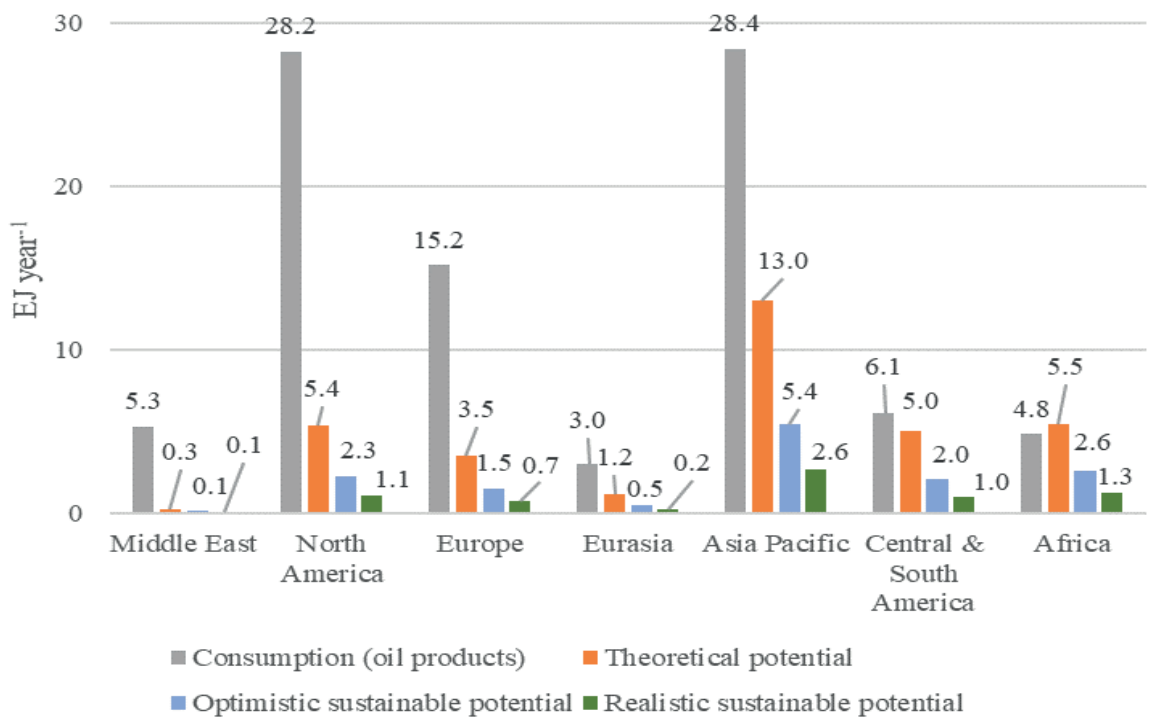

Fig. 5.4. Transport sector's annual consumption of oil products per world region (year: 2017) and the annual net bioethanol production potential from local feedstock. Regions are presented in the ascending order (from left to right) according to their capacity to replace oil products with the net bioethanol. Note: World regions are compiled according to the International Energy Agency's country classifications to match transport sector's oil products consumption data and cover 163 countries (out of 212 countries \& territories included in this study).

The net total annual co-generated electricity ranges from a maximum of $4.3 \mathrm{EJ}$ (theoretical potential) to 1 - $1.9 \mathrm{EJ}$ in the realistic and optimistic sustainable potential, respectively (Fig. 5.3). The gross total annual co-generated electricity is much higher, but most of it is required as input in the bioethanol production. The difference between the gross and net electricity output changes little between the theoretical and sustainable potentials, i.e., $66 \%$ reduction in the theoretical potential and $65 \%$ reduction in the sustainable potential. 
Maize and rice paddy residues contribute the most to the bioethanol output under all potentials (Fig. 5.5). However, soybeans residue is expected to produce more net bioethanol than wheat residue in the theoretical potential while the reverse is true in the two sustainable potential variants. The reason may be that soybean yields relatively larger secondary residues compared to wheat which becomes unavailable under the two sustainable potential variants. Similarly, oil palm fruit residue is one of the top 10 net bioethanol producing feedstocks in the theoretical potential, however, it falls to $25^{\text {th }}$ place in the realistic sustainable potential. The percent contribution of different crop residue categories to the total differs very little between the optimistic sustainable potential and the realistic sustainable potential (not shown).
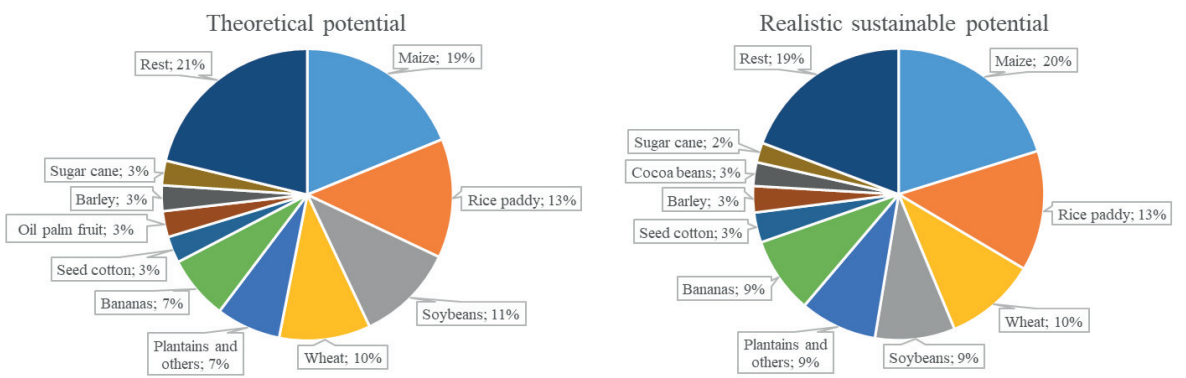

Fig. 5.5. Contribution of different crop residue categories to the global total annual net bioethanol production potential.

At a more aggregate level, cereal residues account for half of the total net bioethanol regardless of the potential (Fig. 5.6). Fruit residues account for 19\% of net bioethanol in the optimistic sustainable and realistic sustainable potentials and only $16 \%$ in the theoretical potential. Oil crops are the next largest contributing crop group that accounts for $19 \%$ of net bioethanol in the theoretical potential and $14 \%$ in the realistic sustainable potentials. Fibres, stimulants, vegetables, and pulses account for 3\% of net bioethanol in each of the potentials. Sugar crops account for 3\% of net bioethanol in the theoretical potential and only $2 \%$ in the optimistic and realistic sustainable potentials. Root crops account for about $1 \%$ of net bioethanol in each of the potentials while crops in the "other" group (i.e., tobacco, natural rubber) and nuts account for less than $0.5 \%$ of net bioethanol in each of the potentials. 


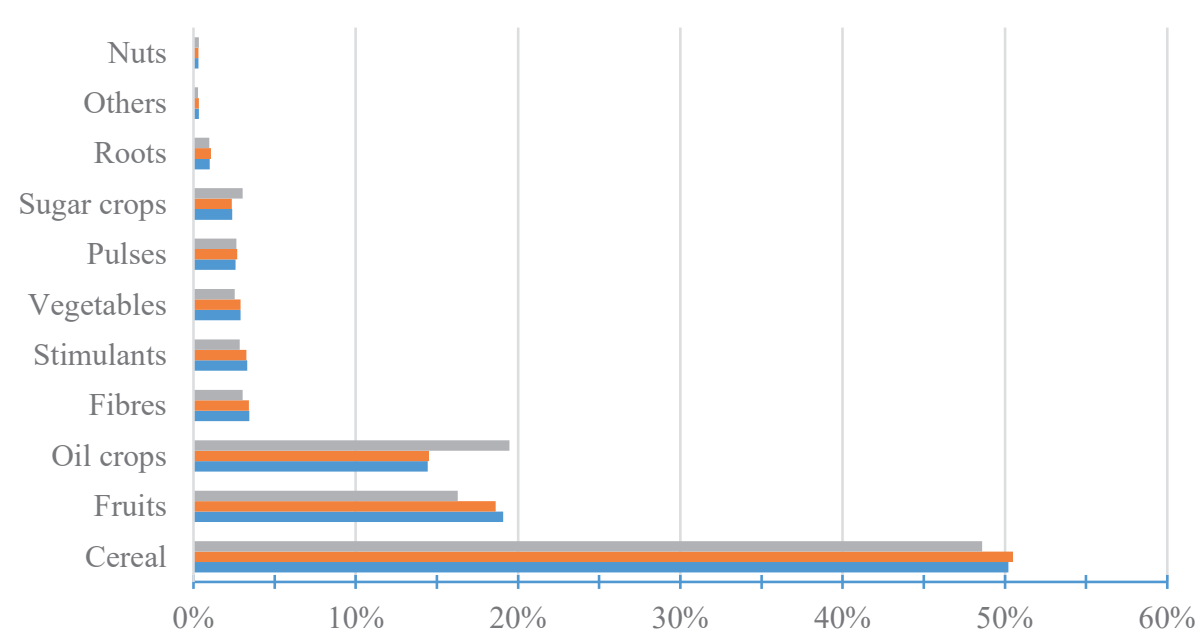

Theoretical potential $\square$ Optimistic sustainable potential $\square$ Realistic sustainable potential

Fig. 5.6. Contribution of different crop groups to the global total net bioethanol production in each of the considered potentials.

Countries with the largest net bioethanol production potentials are: China (mainland), USA, India, and Brazil (Fig. 5.7). These are countries with large crop production and consequently large residue availability. The relative ranking of the major 8 countries does not change between the different potentials with minor reordering occurring thereafter. The percent contribution of different countries varies little between the realistic sustainable potential and the optimistic sustainable potential, although the ordering of some countries changes (e.g., Côte d'Ivoire and Canada are the top $10^{\text {th }}$ and $11^{\text {th }}$ in the realistic sustainable potential while in the optimistic sustainable potential their rankings switch places).
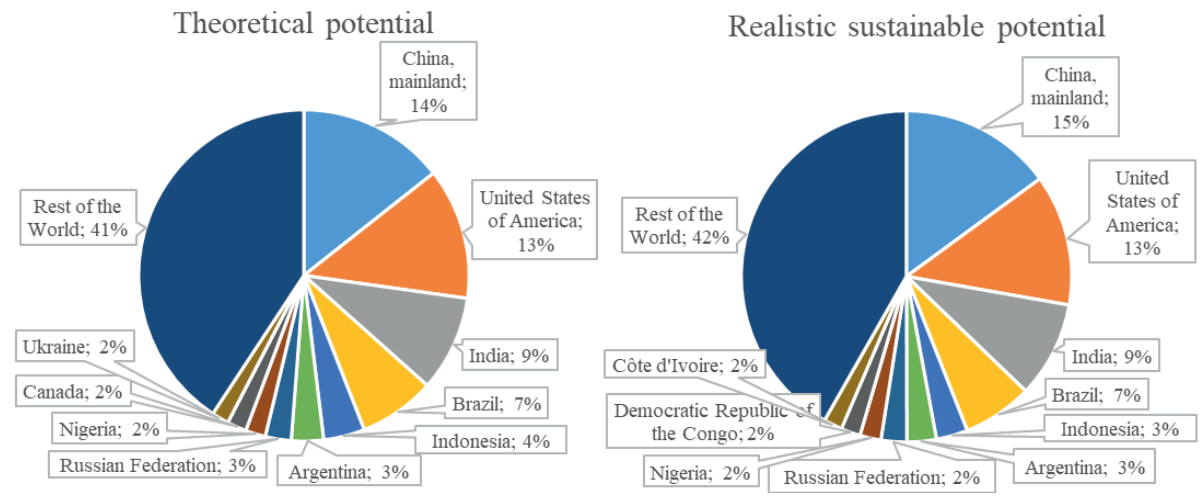

Fig. 5.7. Contribution of different countries to the total annual global bioethanol production potential.

Countries with the largest bioethanol output are the large producers of maize, rice paddy, soybeans, wheat, and bananas. While the share of maize residue in net bioethanol output 
is largest in the USA (52-57\% theoretical vs realistic sustainable potential) and China (28$29 \%$ ), rice paddy residue contributes the most in India (31\%, no difference between the theoretical and realistic sustainable potentials) and China (25\%). Soybeans is the largest contributor in Brazil (45\% in theoretical vs $40 \%$ in realistic sustainable potential) and the USA ( $30 \%$ in theoretical vs $24 \%$ in the sustainable potential). Wheat residue is a large contributor in India (14\%) and China (12\%), while banana residues are responsible for 12 $14 \%$ of bioethanol output in India and $8-10 \%$ in Brazil in the theoretical vs realistic sustainable potential, respectively.

\subsubsection{Land, water and carbon footprints of net bioethanol}

Regional average environmental footprints of net bioethanol reveal differences across world regions (Table 5.3). Central \& South America has the smallest LF per unit of net bioethanol production regardless of potentials and the smallest CF in the realistic sustainable potential. North America has the smallest CF per unit of net bioethanol in theoretical and optimistic sustainable potentials. Europe has the smallest WF per unit of net bioethanol production in the theoretical potential but the Middle East has the smallest WF in the optimistic sustainable and realistic sustainable potentials. The small WF per unit of bioethanol in the Middle East is a likely result of a limited number of crops with small WF that are grown in the region (i.e., vegetables and fruits, Table 5.5).

Table 5.3. Average environmental footprints of net bioethanol production across world regions.

\begin{tabular}{|c|c|c|c|c|c|c|c|c|c|}
\hline \multirow{2}{*}{ Region* } & \multicolumn{3}{|c|}{ LF $\left(\mathrm{m}^{2} \mathrm{MJ}^{-1}\right)$} & \multicolumn{3}{c|}{ WF (L MJ-1) } & \multicolumn{3}{c|}{ CF (g CO2eq MJ-1) } \\
\cline { 2 - 12 } & Theor. & Optimist. & Realist. & Theor. & Optimist. & Realist. & Theor. & Optimist. & Realist. \\
\hline Africa & 1.0 & 2.2 & 4.9 & 103.7 & 136.0 & 173.5 & 19.0 & 23.4 & 31.6 \\
\hline Asia Pacific & 0.5 & 1.3 & 2.7 & 54.9 & 70.5 & 82.3 & 22.9 & 28.6 & 33.4 \\
\hline $\begin{array}{c}\text { Central \& } \\
\text { South } \\
\text { America }\end{array}$ & 0.3 & 0.7 & 1.4 & 43.2 & 56.3 & 68.3 & 10.0 & 12.3 & 14.8 \\
\hline Eurasia & 0.8 & 1.8 & 3.8 & 90.2 & 117.0 & 140.3 & 17.7 & 21.9 & 27.2 \\
\hline Europe & 0.4 & 1.0 & 2.1 & 45.7 & 59.5 & 69.9 & 16.9 & 19.7 & 23.2 \\
\hline Middle East & 0.6 & 1.3 & 2.7 & 47.0 & 55.4 & 62.1 & 14.5 & 15.1 & 17.2 \\
\hline $\begin{array}{c}\text { North } \\
\text { America }\end{array}$ & 0.4 & 0.9 & 1.9 & 62.5 & 84.7 & 103.1 & 9.2 & 11.9 & 15.0 \\
\hline
\end{tabular}

Note: * World regions are compiled according to the International Energy Agency's country classifications and cover 163 countries (out of 212 countries \& territories included in this study).

The global average environmental footprint per unit of net bioethanol production across the main crops is presented in Table 5.4. For all three footprints (LF, WF and CF), a generally increasing trend can be observed going from theoretical to realistic sustainable potential, caused mainly by: (a) exclusion of secondary residues in the two sustainable potential variants that lowers the volume of bioethanol output per unit of land while crop water uses and the GHG emissions (fertilizer, pesticide, indirect machinery; methane from rice cultivation) stay the same; and (b) low price of alternative biomass chains in the two 
sustainable potentials compared to the price of bioethanol that increases resources allocations to bioethanol.

Table 5.4. Global average environmental footprints of net bioethanol production across the main crop residue categories. $\mathrm{LF}$ in $\mathrm{m}^{2} \mathrm{MJ}^{-1}$; WF in $\mathrm{L} \mathrm{MJ}^{-1}$; $\mathrm{CF}$ in $\mathrm{g} \mathrm{CO}_{2}$ eq $\mathrm{MJ}^{-1}$.

\begin{tabular}{|c|c|c|c|c|c|c|c|c|c|c|c|c|c|c|c|}
\hline & \multicolumn{15}{|c|}{ Global average } \\
\hline & \multicolumn{3}{|c|}{$\begin{array}{c}\text { Across all crop } \\
\text { residues }\end{array}$} & \multicolumn{3}{|c|}{ Maize residue } & \multicolumn{3}{|c|}{$\begin{array}{l}\text { Rice paddy } \\
\text { residue }\end{array}$} & \multicolumn{3}{|c|}{ Wheat residue } & \multicolumn{3}{|c|}{$\begin{array}{c}\text { Soybean } \\
\text { residue }\end{array}$} \\
\hline & $\begin{array}{l}\mathrm{L} \\
\mathrm{F}\end{array}$ & WF & CF & $\begin{array}{l}\mathrm{L} \\
\mathrm{F}\end{array}$ & $\begin{array}{l}\mathrm{W} \\
\mathrm{F}\end{array}$ & CF & $\begin{array}{l}\mathrm{L} \\
\mathrm{F}\end{array}$ & $\begin{array}{c}\mathrm{W} \\
\mathrm{F}\end{array}$ & CF & $\begin{array}{l}\mathrm{L} \\
\mathrm{F}\end{array}$ & WF & CF & $\begin{array}{l}\mathrm{L} \\
\mathrm{F}\end{array}$ & $\begin{array}{l}\text { W } \\
F\end{array}$ & $\mathrm{CF}$ \\
\hline $\begin{array}{c}\text { Theoreti } \\
\text { cal }\end{array}$ & $\begin{array}{l}1 . \\
3\end{array}$ & 74.3 & $\begin{array}{c}28 . \\
4\end{array}$ & $\begin{array}{l}0 . \\
3\end{array}$ & $\begin{array}{c}51 . \\
3\end{array}$ & 8.1 & $\begin{array}{l}0 . \\
4\end{array}$ & $\begin{array}{c}45 . \\
1\end{array}$ & $\begin{array}{c}34 . \\
3\end{array}$ & $\begin{array}{l}0 . \\
6\end{array}$ & 82.2 & $\begin{array}{c}11 . \\
7\end{array}$ & $\begin{array}{l}0 . \\
3\end{array}$ & $\begin{array}{c}51 . \\
1\end{array}$ & 7.6 \\
\hline $\begin{array}{l}\text { Optimist } \\
\text { ic } \\
\text { sustain } \\
\text { able }\end{array}$ & $\begin{array}{c}3 . \\
1\end{array}$ & 96.9 & $\begin{array}{c}34 . \\
4\end{array}$ & $\begin{array}{l}0 . \\
7\end{array}$ & $\begin{array}{c}65 . \\
8\end{array}$ & $\begin{array}{c}10 . \\
3\end{array}$ & $\begin{array}{l}0 . \\
9\end{array}$ & $\begin{array}{c}55 . \\
5\end{array}$ & $\begin{array}{c}42 . \\
7\end{array}$ & $\begin{array}{l}1 . \\
5\end{array}$ & $\begin{array}{c}105 . \\
6\end{array}$ & $\begin{array}{c}15 . \\
4\end{array}$ & $\begin{array}{l}0 . \\
9\end{array}$ & $\begin{array}{c}73 . \\
4\end{array}$ & $\begin{array}{c}11 . \\
2\end{array}$ \\
\hline $\begin{array}{c}\text { Realistic } \\
\text { sustain } \\
\text { able }\end{array}$ & $\begin{array}{l}6 . \\
7\end{array}$ & $\begin{array}{c}119 . \\
8\end{array}$ & $\begin{array}{c}44 . \\
4\end{array}$ & $\begin{array}{l}1 . \\
3\end{array}$ & $\begin{array}{c}77 . \\
0\end{array}$ & $\begin{array}{c}12 . \\
6\end{array}$ & $\begin{array}{l}1 . \\
7\end{array}$ & $\begin{array}{c}61 . \\
2\end{array}$ & $\begin{array}{c}48 . \\
1\end{array}$ & $\begin{array}{c}3 . \\
0\end{array}$ & $\begin{array}{c}123 . \\
4\end{array}$ & $\begin{array}{c}19 . \\
6\end{array}$ & $\begin{array}{l}1 . \\
9\end{array}$ & $\begin{array}{c}85 . \\
3\end{array}$ & $\begin{array}{c}13 . \\
9\end{array}$ \\
\hline
\end{tabular}

The global average environmental footprint of net bioethanol varies greatly between crops. The global average LF of net bioethanol ranges from a low of $0.02 \mathrm{~m}^{2} \mathrm{MJ}^{-1}$ in the theoretical potential $\left(0.05-0.09 \mathrm{~m}^{2} \mathrm{MJ}^{-1}\right.$ in optimistic and realistic sustainable potentials) to a high of $14.2 \mathrm{~m}^{2} \mathrm{MJ}^{-1}$ in the theoretical potential $\left(40.8-60.8 \mathrm{~m}^{2} \mathrm{MJ}^{-1}\right.$ in the optimistic and realistic sustainable potentials, respectively). The global average WF of net bioethanol ranges from a low of $4.9 \mathrm{~L} \mathrm{MJ}^{-1}$ to $609 \mathrm{~L} \mathrm{MJ}^{-1}$ in the theoretical potential and from a $5.7 \mathrm{~L}$ $\mathrm{MJ}^{-1}$ to $1559 \mathrm{~L} \mathrm{MJ}^{-1}$ in the realistic sustainable potential. The global average CF of net bioethanol ranges from a low of 1.6 to $2.0 \mathrm{~g} \mathrm{CO}_{2} \mathrm{eq} \mathrm{MJ}^{-1}$ (theoretical vs realistic sustainable potential, respectively) to a high of $597 \mathrm{~g} \mathrm{CO}_{2} \mathrm{eq} \mathrm{MJ}^{-1}$ in the theoretical potential and 1146 $\mathrm{g} \mathrm{CO}_{2}$ eq $\mathrm{MJ}^{-1}$ in the realistic sustainable potential.

Tradeoffs between different footprints become clearer when compared at the more aggregate crops group level (Table 5.5). Specifically, the smallest global average LF and WF per unit of net bioethanol can be obtained by using residue from "fruits" regardless of the potential. Using residue from "fruits" also leads to the smallest CF per unit of net bioethanol in the optimistic and realistic sustainable potentials. However, the smallest global average CF per unit of net bioethanol in the theoretical potential can be obtained by using residue from stimulants. In contrast, using root crops leads to the largest LF and CF per unit of net bioethanol regardless of the potential, while using crops from the "other" group leads to the largest WF per unit of net bioethanol in the theoretical and sustainable potentials. 
Table 5.5. Global average environmental footprint of net bioethanol production per crop groups.

\begin{tabular}{|c|c|c|c|c|c|c|c|c|c|}
\hline \multirow{2}{*}{$\begin{array}{l}\text { Crop } \\
\text { groups }\end{array}$} & \multicolumn{3}{|c|}{$\mathrm{LF}\left(\mathrm{m}^{2} \mathrm{MJ}^{-1}\right)$} & \multicolumn{3}{|c|}{ WF (L MJ-1) } & \multicolumn{3}{|c|}{$\mathrm{CF}\left(\mathrm{g} \mathrm{CO}_{2} \mathrm{eq} \mathrm{MJ}^{-1}\right)$} \\
\hline & Theor. & Optimist. & Realist. & Theor. & Optimist. & Realist. & Theor. & Optimist. & Realist. \\
\hline Cereal & 0.4 & 1.0 & 2.0 & 62.6 & 81.5 & 95.5 & 16.6 & 21.0 & 25.1 \\
\hline Fibres & 0.3 & 0.7 & 1.4 & 50.8 & 60.8 & 68.0 & 7.1 & 8.8 & 10.6 \\
\hline Fruits & 0.1 & 0.2 & 0.5 & 17.5 & 25.1 & 34.1 & 4.6 & 3.1 & 3.4 \\
\hline Nuts & 1.2 & 3.0 & 6.2 & 120.7 & 157.2 & 173.0 & 6.3 & 8.7 & 10.7 \\
\hline Oil crops & 0.4 & 1.3 & 2.7 & 62.1 & 81.9 & 93.9 & 7.5 & 11.7 & 14.7 \\
\hline Others & 1.6 & 3.2 & 6.5 & 165.3 & 179.9 & 194.7 & 9.4 & 10.9 & 13.7 \\
\hline Pulses & 1.0 & 2.3 & 4.8 & 77.8 & 99.6 & 117.7 & 13.6 & 18.6 & 24.9 \\
\hline Roots & 1.9 & 3.9 & 8.3 & 45.9 & 48.8 & 53.2 & 133.1 & 142.8 & 161.3 \\
\hline Stimulants & 0.3 & 0.5 & 1.1 & 86.0 & 124.0 & 163.4 & 4.0 & 5.1 & 6.5 \\
\hline Sugar crops & 0.3 & 0.9 & 1.9 & 66.1 & 78.0 & 84.6 & 23.1 & 26.8 & 28.9 \\
\hline Vegetables & 0.7 & 1.3 & 2.7 & 15.3 & 15.8 & 16.4 & 37.5 & 39.4 & 43.4 \\
\hline
\end{tabular}

Total CF of the annual global net bioethanol production from the 123 crop residues calculated in this study ranges from 474.4 Megatonne (Mt) in the theoretical potential to 250.7-143.3 Mt in the optimistic sustainable potential and realistic sustainable potential, respectively. Replacing oil products consumed in the transport sector (assuming the reported carbon intensity of road transport of $68.0 \mathrm{~g} \mathrm{CO}_{2} \mathrm{MJ}^{-1}$ )(IEA, 2020b), with lignocellulosic bioethanol can lead to the relative $\mathrm{CO}_{2}$ emission savings in the range of 70$79 \%$ (Table 5.6). CF is composed of many components that makes generalizations difficult, but even so, when electricity is required from the grid (often for crop residues with high moisture content that do not co-generate much electricity, i.e., roots, vegetables; Table 5.5), the $\mathrm{CF}$ of bioethanol increases. In some instance, the CF of bioethanol exceeds the carbon intensity of road transport. Removing countries with an average CF of greater than $68.0 \mathrm{~g}$ $\mathrm{CO}_{2} \mathrm{MJ}^{-1}$ has small effect on the relative emission savings, where only in the case of realistic sustainable potential, exclusion of countries with large CF leads to a slight increase of relative emission savings from $70 \%$ to $71 \%$. 
Table 5.6. Comparing total and relative emission savings in the transport sector by replacing oil products with the lignocellulosic bioethanol potential calculated in this study.

\begin{tabular}{|c|c|c|c|c|c|}
\hline \multirow{2}{*}{ Potential } & \multicolumn{3}{|c|}{ Emissions (Mt CO $)$} & \multicolumn{2}{c|}{ Emission savings (\%) } \\
\cline { 2 - 6 } & $\begin{array}{c}\text { Net } \\
\text { bioethanol } \\
\text { production }\end{array}$ & $\begin{array}{c}\text { Corresponding } \\
\text { emissions from } \\
\text { oil products }\end{array}$ & $\begin{array}{c}\text { Transport } \\
\text { sector's total } \\
\text { emissions } \\
\text { with } \\
\text { replacement** }\end{array}$ & $\begin{array}{c}\text { Total } \\
\text { emission } \\
\text { emission } \\
\text { savings } \\
\text { savings in } \\
\text { the } \\
\text { transport } \\
\text { sector }\end{array}$ \\
\hline Theoretical & 474.4 & 2310.7 & 6203.7 & $79 \%$ & $23 \%$ \\
\hline $\begin{array}{c}\text { Optimistic } \\
\text { sustainable }\end{array}$ & 250.7 & 989.5 & 7301.1 & $75 \%$ & $9 \%$ \\
\hline $\begin{array}{c}\text { Realistic } \\
\text { sustainable }\end{array}$ & 143.3 & 481 & 7702.3 & $70 \%$ & $4 \%$ \\
\hline
\end{tabular}

Notes: * The current global average carbon intensity of road transport is assumed $68 \mathrm{~g} \mathrm{CO}_{2} \mathrm{MJ}^{-1}$ (IEA, 2020b); ${ }^{* *}$ Original transport sector's emissions in $2017-8040 \mathrm{Mt} \mathrm{CO}_{2}$.

\subsection{Discussion}

For the first time, this study estimates the bioethanol production potential from 123 crop residues (primary and secondary) across 190 countries and 20 territories and assumes different potentials that are linked to different constraints on crop residue availability.

\subsubsection{Overview of lignocellulosic bioethanol potential}

The annual global total lignocellulosic bioethanol yield in terms of net energy calculated in this study, ranges from a maximum of $34 \mathrm{EJ}$ to a likely range of 14.6 to $7.1 \mathrm{EJ}$ per annum. Even at the lowest end of this range, the output energy exceeds current (i.e., 2018) global total liquid biofuel production of 5729 GWh (0.02 EJ) (IRENA, 2020) by orders of magnitude. Net co-generated electricity yield of 1.0-4.3 EJ means adding clean electricity equaling $50-200 \%$ of the 2018's electricity supply from solar photovoltaics (1.98 EJ) (IRENA, 2020). However, despite such an impressive potential stored in crop residues, there are number of drawbacks that will lessen their expected impact. The five main impediments are: (5.4.2) output energy can replace only a fraction of that consumed in the transport sector, far less than the scale of biofuel use envisioned by prominent energy scenarios and with even smaller GHG emission reductions; (5.4.3) time is of essence where every year counts for climate action, but the current gap between actual production and production at the scales calculated in this paper remains gargantuan; (5.4.4) the environmental footprint family of solar PV and solar PV derived hydrogen is smaller than the environmental footprint of net bioethanol production; (5.4.5) a lack of policy coherence among different sectors (e.g., agriculture, transportation, energy) means that the land, water and carbon footprints of lignocellulosic bioethanol will remain uncertain in the long run; and (5.4.6) stable feedstock supply can be difficult to maintain with a growing 
demand for biomass resources supporting biobased economies. The subsequent sections address these five impediments.

\subsubsection{Lignocellulosic bioethanol - non-viable drain?}

We found that energy stored in the net lignocellulosic bioethanol produced from 123 crops can replace between 7-31\% of energy consumed in the transport sector from oil products and reduce transport sector's emissions from a maximum of $23 \%$ to a likely range of $4-9 \%$. In some countries, the transport sector's annual consumption of oil is so large that the global total bioethanol produced from 123 crops around the globe is not likely (i.e., optimistic sustainable potential and realistic sustainable potential outputs) to be sufficient to satisfy their individual country-scale or regional demands. For instance, in none of the global regions, the net bioethanol production from local feedstock in the optimistic or realistic sustainable potentials is insufficient to replace dependence on oil products. Not only that, even using the global total annual bioethanol production capacity under optimistic sustainable potential (16.3 EJ as gross and $14.6 \mathrm{EJ}$ as net) and realistic sustainable potential (8.2 EJ as gross and 7.1 EJ as net), there is not enough to satisfy the United States of America (23.8 EJ) or the People's Republic of China's (21.5 EJ) consumption of oil products in the transport sector (IEA, 2020b).

The emission savings resulting from replacement of oil products with net bioethanol are too small to have a large effect on climate goals. Assuming that the carbon intensity of the whole transport sector is the same as that of road transport and using the total available net bioethanol to replace equivalent amounts of energy used in the transport sector with crop/country specific CF, reduces the total sector's emissions (i.e., $8040 \mathrm{Mt}$ of $\mathrm{CO}_{2}$ in 2017) (IEA, 2020b) by $23 \%$ (theoretical potential) to $4-9 \%$ (sustainable realistic and optimistic variants, respectively). Realistically, such reduction can offset the share of global transport emissions that is growing, nearly $1.9 \%$ annually since 2000 (up to 2019) (IEA, 2020d), but has little effect on drastically decarbonizing the transport sector to meet the climate goals without demotorization and expansion of electric (IPCC, 2018) and hydrogen based vehicles (Holmatov \& Hoekstra, 2020c).

Biofuel targets envisioned in some prominent energy scenarios are not likely to be met without a large contribution of conventional biofuels. For instance, IEA's 2 DS envisions some 30\% (30 EJ) coming from biofuels by 2060 (IEA, 2020a) while International Renewable Energy Agency's (IRENA) REMap Scenario assumes 22\% (22 EJ) of transport energy coming from biofuels by 2050 (IRENA, 2018). Findings of this study suggest that the likely (sustainable) net bioethanol production potential will be optimistically around 15 EJ (but realistically around 7.1 EJ) which is far less than the assumed biofuel values. Meeting such targets would involve, to a large degree, continued dependence on conventional biofuels or a shift to electricity or hydrogen from sun or wind. An additional reason is that despite having a broad spectrum of possible advanced biofuel technologies such as Fatty Acid Methyl Ester (FAME), Hydrotreated Vegetable Oils (HVO), synthetic fuels via gasification, pyrolysis oils and others (that may be even cheaper to produce than lignocellulosic bioethanol) (IEA, 2020a) such technologies nevertheless mostly utilize and hence compete for the same feedstock (i.e., agricultural residues). Moreover, output of some advanced biofuel technologies is not necessarily compatible with existing infrastructure (e.g., pyrolysis oils) (IRENA, 2019a; Karatzos et al., 2014), and is often 
regarded as conventional biofuel technology rather than advanced (e.g., FAME using palm oil as feedstock) (IRENA, 2019a).

Present day biofuel production is mostly conventional. In 2017, biofuels accounted for $92 \%$ of renewable energy use in the transport sector (IEA, 2018b). While lignocellulosic bioethanol production was virtually non-existent, conventional biofuel production reached 143 billion liters in 2017 (IEA, 2018b). IEA (2018b) estimates the advanced biofuels production will reach 1.4 billion (0.9 Mtoe or $0.038 \mathrm{EJ}$ ) by 2023 with cellulosic bioethanol making up $60 \%$ or 0.54 Mtoe (0.023 EJ). In other words, the scale of advanced biofuel production in 2023 will reach $1 \%$ compared to the scale of conventional biofuels produced in 2017. Although some 70 small-scale advanced biofuel plants are dispersed around the world, they add relatively little to the production compared to the commercial-scale plants (IEA, 2018b). An estimated number of large-scale advanced lignocellulosic bioethanol plants in 2018 is reported between 5 (being constructed) (IEA, 2018b) and 12 (being operational) (IRENA, 2019a). This falls far short of the scale required to reach the production volumes calculated in this study.

\subsubsection{Mind the gap?}

The speed of making the energy transition to reach climate goals is a key element for consideration (Sovacool, 2016). The advanced biofuels demand of 25 EJ by 2060 estimated by the IEA's Bioenergy Roadmap requires building about 4,300 large scale plants (200 MW capacity operating 8000 hours/year) (IEA, 2020a). Similarly, the advanced biofuel demand of $16 \mathrm{EJ}$ to meet $18 \%$ of the transport sector's final energy consumption by 2050 requires building 80-100 refineries annually costing about 20 billion USD per year (IRENA, 2019a). However, investment trends in advanced biofuels production are declining since 2011, and did not even reach one billion USD in 2017 or 2018 (IRENA, 2019a). Most of the announced and under-construction advanced biofuel plants are located in the developed countries of Europe (32\%) and the USA (27\%), that are responsible for some $60 \%$ of global share, while India (18\%), and Canada (5\%) are the only other major sovereign players with the rest of the world responsible for less than $20 \%$ (IEA, 2018b).

As with all innovations, the biofuel technology cannot spread simultaneously and the diffusion would cause temporal and spatial differences (Grübler, 1996). However, the spatial and temporal difference in the speed of scaling up the technology to reach the level of production potential calculated in this study may come too late to support the climate goals. Without efficient measures to reduce our GHGs by 2030, global warming is likely to reach $1.5 \mathrm{C}^{\circ}$ which increases climate-related risks for human and natural systems (IPCC, 2018).

While the early adopters of advanced biofuel technology are likely to be developed countries with sufficient investment funds, concentrating investments in developed countries alone would not yield the necessary result. Currently, the final energy consumption in non-OECD transport sector is growing faster than in OECD countries (i.e., $5.7 \%$ vs $2.4 \%$ from 2015 to 2017) (IEA, 2020b) and is expected to increase by $77 \%$ from 2018 to 2050 while the OECD energy consumption in the transport sector during that period declines by $1 \%$ (USEIA, 2019). Given the much higher price tag of advanced bioethanol (29-44 EUR/GJ) compared to fossil fuel (8-14 EUR/GJ) or even conventional bioethanol prices (which varies from 13-15 EUR/GJ in the USA to 18-29 EUR/GJ in the Netherlands) 72 
(IEA, 2020a) developing countries are not likely to make the transition to using lignocellulosic bioethanol a priority. Moreover, many countries are not on track to meeting various sustainable development goals (Sadoff et al., 2020) and tackling numerous societal challenges simultaneously with limited funds would likely prevent countries from overspending on advanced biofuels even when the price of such a tradeoff threatens the planet and humanity. Filling the gap between the current almost non-existent lignocellulosic bioethanol production to at least 7.1 EJ per annum would optimistically take decades.

\subsubsection{Mind the environmental footprint: lignocellulosic bioethanol vs solar PV electricity and hydrogen}

In comparison with the environmental footprint of solar PV electricity and solar PV derived hydrogen, the environmental footprint family of lignocellulosic bioethanol is larger. Certainly, the lignocellulosic bioethanol's footprint calculated in this study is based on the value of bioethanol over the price of all co-products and is thus sensitive to price fluctuations. Particularly, changes in the price of bioethanol, electricity, crops or alternative biomass supply chains can impact the footprint allocations. The alternative was to use a physical allocation based on mass. However, even the physical allocation faces challenges, such as: (i) electricity, a co-product of biorefinery cannot be measured in mass units; and (ii) data on the actual moisture content of residue becomes crucial (e.g., moisture content of the same residue for feed vs for combustion would be different) but is difficult if not impossible to obtain.

In comparative terms, the environmental footprint of lignocellulosic bioethanol is larger than the environmental footprint of conventional bioethanol or solar PV electricity or solar PV derived hydrogen. For instance, the average LF of lignocellulosic bioethanol (Table 5.4) is orders of magnitude larger than the LF of solar PV electricity $\left(0.001 \mathrm{~m}^{2} \mathrm{MJ}^{-1}\right)$ and solar PV derived hydrogen $\left(0.002 \mathrm{~m}^{2} \mathrm{MJ}^{-1}\right)$ (Holmatov \& Hoekstra, 2020b). Similarly, even the smallest average LF of net lignocellulosic bioethanol production from "fruits" ( 0.11 to 0.43 $\mathrm{m}^{2} \mathrm{MJ}^{-1}$, theoretical vs realistic sustainable potential) is still larger than the LF of conventional bioethanol from sugar beet or sugarcane $\left(0.07 \mathrm{~m}^{2} \mathrm{MJ}^{-1}\right)$ (Holmatov et al., 2019).

The WF comparison between lignocellulosic bioethanol and conventional bioethanol depends on the feedstock but the WF of lignocellulosic bioethanol is larger than the WF of solar PV electricity and solar PV derived hydrogen. The global average WF of conventional bioethanol at $57 \mathrm{~L} \mathrm{MJ}^{-1}$ (sugar beet feedstock) (Holmatov et al., 2019) is larger than the average WF of lignocellulosic bioethanol from "fruits" (17.5 - 34.1 L MJ-1 in theoretical vs realistic sustainable potential) but smaller than the WF of lignocellulosic bioethanol from cereal (62.6 - 95.5 $\mathrm{L} \mathrm{MJ}^{-1}$ in theoretical vs realistic sustainable potential).

The average CF of lignocellulosic bioethanol falls below $10 \mathrm{~g} \mathrm{CO}_{2} \mathrm{eq} \mathrm{MJ}^{-1}$ only when residues from "fruits" or "stimulants" are used as feedstock whereas the carbon footprint of solar PV (harmonized across studies) is approximately 5.6 - $6.9 \mathrm{~g} \mathrm{CO}_{2} \mathrm{eq} \mathrm{MJ}^{-1}$ (Louwen et al., 2016). The average CF of conventional bioethanol from sugarcane and sugar beet (14-19 $\mathrm{g} \mathrm{CO}_{2}$ eq MJ-1) (Holmatov et al., 2019) is also smaller than the average CF of lignocellulosic bioethanol from "cereal" residues $\left(16.6-25.1 \mathrm{~g} \mathrm{CO}_{2} \mathrm{eq} \mathrm{MJ}{ }^{-1}\right.$ theoretical vs realistic sustainable potential). 
Decisions on which alternative fuels and vehicles to promote in decarbonizing the transport sector, should consider differences between environmental footprints of alternatives fuels/electricity and local land and water resource availability and scarcity, and account for the food-energy nexus.

\subsubsection{Walk the line: nexus thinking is vital}

Long-term sustainability of advanced bioethanol production can benefit from a coherence between different sectors such as the agriculture, energy and transport sectors. As the findings of this study suggest, the net bioethanol production is context specific and can be favorable from one resource perspective while simultaneously being unfavorable from another, depending on the crop and region. Interactions between different resource sectors or nexus (Simpson \& Jewitt, 2019) thinking can help to reduce land, water and carbon footprints of lignocellulosic bioethanol because the tradeoff or synergy between different footprints, can be managed. For instance, expansion of green electricity can help lower the $\mathrm{CF}$ of the grid and reduce the $\mathrm{CF}$ of net bioethanol for feedstocks that require additional electricity input from the grid.

In another example, farmers will not grow relevant crops (i.e., high bioethanol yielding residues) unless there is a stable demand while in the absence of relevant crop cultivation in the area, project developers cannot count it as a guaranteed feedstock supply (IRENA, 2019a). In such cases, incentivizing farmers to grow specific crops (agriculture domain) before the demand is firmly established can help meet the transport and energy targets. In a similar way, agricultural policies can help keep seasonal price variations to a minimum by ensuring sufficient supply chain capacity to dry and store the residue feedstock (IRENA, 2019a). Price of feedstock has a large effect on the price of lignocellulosic bioethanol and thus site selection to ensure low-cost supply of feedstock is important (IEA, 2020a). Price of feedstock accounts for $70-90 \%$ of total production cost for conventional vs 35-50\% for lignocellulosic bioethanol (IRENA, 2019a).

A nexus approach can also help harmonize policies to avoid cross-sectoral damages. For instance, Brazil is conducting trials of new sugar cane varieties that can yield higher biomass without compromising sugar yield (IEA, 2018b). Focusing on maximizing bioethanol yield per unit of land (sugarcane can be used for conventional and lignocellulosic bioethanol production) to meet transport targets can damage agriculture in the long term. Moreover, monoculture raises sustainability concerns (Bos et al., 2013; Elbehri et al., 2013; IRENA, 2019a), so if crops are to be rotated, then the land, water and carbon footprint of advanced bioethanol will change at least on a yearly basis. On the flip side, existing or future undesirable agricultural policies such as subsidies can mask the real cost of biofuels in terms of resource use and even lead to depletion of scarce local resources. Water is commonly subsidized despite being a scarce and energy intensive resource (Sadoff et al., 2020) (e.g., in parts of Uzbekistan, water is lifted to crop fields located at heights of up to 200 meters by means of pumps (Djumaboev et al., 2019)).

\subsubsection{Too much but not enough}

Biomass has many existing and emerging uses that makes the future availability of residue for biofuel production uncertain. Increasingly, biomass is used to produce monomers and polymers to replace petroleum based resources (Harmsen et al., 2014; Llevot et al., 2016). 
Under a business as usual scenario, the biomass use for chemicals and plastics is expected to grow several folds by 2050 (Piotrowski et al., 2015). When coupled with the increase in demand for traditional biomass uses such as for animal feed and traditional bioenergy, the total biomass demand is expected to grow $50 \%$ by 2050 under a business-as-usual scenario (Piotrowski et al., 2015). As climate change is likely to affect food security and water supply (IPCC, 2018), the crop cultivation pattern may change suddenly causing shortages of residue for bioethanol production. Some studies (Bos-Brouwers et al., 2012) suggest that among the competing demands for biomass, biofuel production has the lowest priority and if faced with a choice of residue for fuel vs residue for feed and products, the price of feedstock may not be the only determining factor. In the US, most (if not all) of the advanced biofuel plants failed because the plub was pulled on state or federal support (IRENA, 2019a). In the absence of state support and with an uncertain future for residue supply, making an investment in new technology calls for a thorough techno-economic assessment that considers all risks, even while the clock is ticking, bringing us closer to the $1.5^{\circ} \mathrm{C}$ warmer planet.

\subsection{Conclusion}

This paper estimates the theoretical and two variants of sustainable lignocellulosic bioethanol production potentials using 123 crop residues in 192 countries and 20 territories. Land, water and carbon footprints per unit of net bioethanol output are calculated per crop residue and country/territory. The energy output is differentiated between gross and net by subtracting energy inputs into bioethanol production.

The results combined with the current state of advanced bioethanol production and supply of biomass leads to two major conclusions. First, lignocellulosic bioethanol production can replace only a small share of energy from oil products consumed in the transport sector. Lignocellulosic bioethanol production based on sustainable utilization of crop residues can replace only a small share of transport sector's demand for oil products -7 to $13 \%$. Even the theoretical utilization of all crop residues can replace less than one third of the transport sector's demand for oil products $-31 \%$. At the regional scale, replacing oil products used in the transport sector with net bioethanol produced from local feedstock is not possible anywhere when considering the environmental constraints.

Second, the environmental footprint of advanced bioethanol varies based on crops, countries and the potentials, but overall it exceeds the footprints of conventional bioethanol, solar PV electricity, and solar PV derived hydrogen. In terms of crop groups, residue from "fruits" generally leads to smallest footprints per unit of net bioethanol while it is more difficult to generalize a crop group with the largest footprints. That is because there are LF, WF and CF tradeoffs among different crop groups. In terms of country groups, Central \& South America has the smallest LF regardless of the variant considered and the smallest $\mathrm{CF}$ for the realistic potential. From the water perspective, Europe and the Middle East have small WF per unit of net bioethanol. North America has the smallest CF in theoretical and optimistic sustainable potentials. Finally, in terms of potentials, the footprints become larger moving from theoretical to optimistic sustainable and realistic sustainable potentials: sustainability of agricultural management does go at the expense of environmental resource efficiency of bioethanol production from residues. 
The gap between current bioethanol production capacity and the required capacity to match the level of production calculated in this study is large and may require decades to fill while the future supply of residue and the environmental footprint of future lignocellulosic bioethanol production remains uncertain. Even when the theoretical production capacity can be reached, if we rely on current modes of transport with internal combustion engines and feed them as much as possible with crop residue based lignocellulosic bioethanol we will remain heavily dependent on fossil fuels. Therefore reducing the motorization rate and shifts in modes of transport, e.g. towards a fleet of electric or hydrogen based vehicles, is necessary to decarbonize the transport sector. 


\section{Conclusion}

The aim of this dissertation is to contribute to the discourse concerning energy transition to low-carbon technologies in the transport sector in order to meet climate targets while considering the land and water implications of alternative fuels. First, I calculated the land, water and carbon footprints of conventional vs second generation biofuels per unit of net output to estimate the scale of emission reductions per unit of energy and the scale of land and water resources required as a tradeoff. Second, I estimated the global biofuel production potential under different sustainability criteria. Below, I structure conclusions around the three specific research questions.

\subsection{What are the land, water, and carbon footprints of conventional and advanced biofuels per unit of net energy output using different feedstock types and what is the environmental footprint of renewable electricity and hydrogen?}

Based on the results of Chapter 2, 4 and 5, I conclude that the GHG emission savings of bioenergy vary across different feedstocks. In Chapter 2, I looked at the land, water and carbon footprints of crop-based bioethanol and biodiesel. The findings of Chapter 2 shows the large water and land footprints of crop based biofuels, which is consistent with the findings of previous studies (Gerbens-Leenes \& Hoekstra, 2012; Gerbens-Leenes et al., 2009b; Rulli et al., 2016). Importantly, relative to the previous studies, I expanded methodology in Chapter 2 in two respects: (a) the footprints are calculated per unit of net biofuel output (defined as gross biofuel output minus energy inputs in the production); and (b) the land and water footprints of biofuels are reported along with their carbon footprints to demonstrate the scale of resource tradeoffs per unit of GHG emission abatement.

Sensitivity analysis of Chapter 2 results showed that increasing yields would lead to the largest reduction of environmental footprints, but the result of sensitivity analysis is not likely to affect the main conclusions. There are two reasons for this: (a) the crop yields are likely to decline because of climate change impacts such as the temperature and precipitation changes (IPCC, 2018); and (b) increasing crop yield requires a combination of factors such as water availability, nitrogen availability and plant genetic improvement (Sinclair \& Rufty, 2012), thus applying additional water and nitrogen entails that reducing environmental footprint of conventional biofuels by increasing crop yields would be, at least partially, offset by the additional applications of resources. The overall take-home messages of this chapter are that (1) crop-based bioethanol can lead to emission savings but at a high cost of land and water resources, and (2) crop-based biodiesel does not lead to emission savings while requiring large land and water resources.

Findings of Chapter 4 and 5 suggest that the land, water and carbon footprints of advanced, residue-based bioethanol are country and crop specific. Overall, the carbon footprint of lignocellulosic bioethanol from crop residues is smaller than the carbon footprint of fossil fuels and can lead to emission savings. While the emission saving 
potential of lignocellulosic bioethanol is largely accepted (European Commission, 2018), the land and water tradeoffs calculated in Chapter $4 \& 5$ are the first of a kind. The findings of these chapters suggest that the assumption on the allocation method affects the land, water and carbon footprints of bioethanol considerably. Allocation of resource inputs to marketable products can be based on price or physical units such as mass or energy (Luo et al., 2009; Reijnders \& Huijbregts, 2008). In our case, allocation based on the values of output products (bioethanol being an additional output next to the harvested crop) was the most logical choice for three reasons. First, allocation based on mass of residue compared to the mass of the crop fraction would have led to overallocation of resource inputs to residues simply because the residue fraction of most field crops weighs more than their yield fractions (e.g., see the residue-to-product ratio in Table D3, Appendix D). Second, allocating based on the energy output (i.e., the heating value of bioethanol) would have required data on the bioethanol yield from the economic yield fraction of 123 crops, which entails complex calculations and is a daunting task. Third, in the background of many existing and emerging policies promoting biobased economy or circular agriculture, values of crop residue are plausible to be relevant in future economies. In addition to the assumption on the allocation methods, assumptions on what share of total residue is harvestable and thus available as feedstock to bioethanol also has a very large impact on land, water and carbon footprints of lignocellulosic bioethanol.

\subsection{What choice of transport fuel reduces the carbon footprint the most with the least land and water requirements?}

Findings of Chapter 3, where I calculate and compare the land, water and carbon footprints per unit of distance driving in cars utilizing hydrogen, electricity, fossil fuels and a blend of biodiesel with diesel and bioethanol with gasoline, suggest that biofuelbased cars are the worst performers. Findings of Gerbens-Leenes and Hoekstra (2011) has also revealed the large water footprint of biofuel-based transport across different modes of transport while Transport \& Environment (2018) has previously shown the relatively better well to wheel energy efficiency of using electricity and hydrogen to power vehicles. In Chapter 3, I go beyond the water footprint analysis of biofuels to also include the land and carbon footprints of conventional and alternative fuels (including renewable electricity and hydrogen) and compare footprints per unit of distance using the actual fuel efficiency of mid-sized vehicles designed to run on the chosen type of fuel or electricity. The findings of Chapter 3 reveal that driving a car with a $20 \%$ blend of rapeseed based biodiesel with conventional diesel leads to higher emissions than driving a gasoline car while requiring 683 times more water. Driving a car with an $85 \%$ blend of sugar beet based bioethanol with conventional gasoline cuts emissions by half compared to emissions of a gasoline car but requires 655 times more water. The smallest footprints per unit of a traveled distance are achieved in electric vehicles if powered with electricity from solar photovoltaics (PV), followed by hydrogen based vehicles if hydrogen through electrolysis is powered by solar PV. 


\subsection{How much of the present-day oil product use in the transport sector can be potentially replaced with biofuels and what are implications for GHG emissions, and appropriation of land and water?}

In Chapter 2, I estimated resources that are required to reach a specific biofuel demand. Particularly, I calculated the required amount of land and water resources as well as the GHG emissions from (1) a complete transition to a bioenergy mix composed of conventional biofuels (for the transport sector), heat and bioelectricity and (b) replacing $9.8 \%$ of current energy consumption with a bioenergy mix composed of conventional biofuels, heat and bioelectricity. While the complete transition to bioenergy is not possible, because the land and water requirements are too excessive, all but rapeseed feedstock can lead to large GHG savings compared to current emissions. In contrast, replacing only $9.8 \%$ of current energy consumption with a bioenergy mix is theoretically possible and can lead to small GHG emission reduction but will require $11-14 \%$ of the global arable land and a water flow equivalent to $18-25 \%$ of the current water footprint of humanity. The findings of this chapter are similar to the findings of a study by Mekonnen et al. (2016), who only assessed the water footprint of future energy scenarios and concluded that low-carbon scenarios assuming a large share of bioenergy lead to large water footprints. In Chapter 2, I expand on their work by (a) also estimating the land, and carbon footprints; (b) estimating footprints per unit of net energy; and (c) putting the findings in the context of feasibility with regards to land and water availability.

Biofuels can be produced from crops as well as non-food biomass. In Chapter 4 and Chapter 5, I estimate the biofuel (in terms of bioethanol) production potential using crop residues. I started by focusing on the residue from maize and wheat generated in 27 member states in the European Union (Chapter 4) and then zoomed out to the global scale and focused on the residue from 123 crops produced in 192 countries and 20 territories (Chapter 5). No study has assessed the lignocellulosic biofuel potential from crop residues at the EU or at the global scale, thus the findings of these studies are the first of a kind. Moreover, the findings of Chapters 4 \& 5 suggest that despite the hype about advanced biofuels being able to decarbonize our transport sector, the actual energy outputs of currently viable lignocellulosic bioethanol are relatively small. The gross bioethanol production potential in the EU is $470 \mathrm{PJ}$ (404 PJ as net) and can only replace around 3.4\% of the fossil fuels currently used in the transport sector. At the global scale, the net bioethanol production potential from 123 crop residues ranges from 7.1 EJ to 34 EJ, depending on the availability of residue, and can replace between 7 and $31 \%$ of the fossil fuels used in the transport sector. At most, the global annual GHG emissions from switching to lignocellulosic bioethanol is 474 megatonne (Mt) of carbon dioxide while the realistic sustainable range is $143 \mathrm{Mt}$. These numbers translate to relative emission savings of $70-79 \%$ as compared to using current fossil fuel mix. 


\subsection{Future Research Directions}

The following future research directions can build on the methods and findings of this study to further improve our understanding of resource tradeoffs in alternative fuel production pursued to decarbonize the transport sector.

Land, water and carbon footprints of conventional biofuels per country, using country specific inputs can obtain more accurate results. The land, water and carbon footprints of conventional biofuels calculated in this study assumed (a) global average data and (b) a circular system (a share of outputs are used as inputs). In reality, inputs for conventional biofuel production varies among countries and the biofuels are currently not produced in circular systems.

Land, water and carbon footprints of a range of advanced biofuels are necessary to identify viable options. This study has looked into the land, water and carbon footprints of bioethanol because that is currently the commercially mature technology that produces ready-to-use biofuels mostly for the road transport. Other relevant technologies are readyto-use biofuels for aviation and maritime transport or for the road transport using alternative routes such as pyrolysis oil, biogas, and synthetic fuels that are at or about to reach a commercial scale but their output products require additional purification and upgrading to become ready-to-use biofuels. Knowing their land, water and carbon footprints can help assess their potential and role in meeting climate targets.

Land, water and carbon footprints of a range of non-biomass based alternative fuels is unknown. This study mainly focused on the environmental footprint of biofuels, while meeting climate goals entails a large mix of alternative fuels, where liquified natural gas, propane, and hydrogen through non-electrolysis reactions are all suggested choices. Estimating and comparing their environmental footprint with biofuels and dominant transport fossil fuels can reveal their role in meeting the climate targets as well.

\subsection{Final remarks}

Humanity is approaching a decisive point for making climate-smart choices to avert serious climate risks. For the first time, this research has assessed the tradeoffs among land, water and the GHG emissions through the case of conventional and advanced biofuels production. As such it contributes to an increased understanding of the scale of land and water tradeoffs required to produce biofuels to meet climate targets. While biofuels production and use can help decarbonize the transport sector, large scale biofuel production can lead to increased pressure on scarce land and water resources (in case of conventional biofuels) or require bridging a large production capacity gap very quickly and may lead to increased competition over crop residues (in the case of advanced biofuels). Therefore, meeting the climate targets while reducing land, water and carbon footprints in the transport sector calls for a blend of various alternative fuels with hydrogen and electricity from renewable sources being the most attractive option. 


\section{List of references}

Abbas, A., \& Ansumali, S. (2010, 2010/12/01). Global Potential of Rice Husk as a Renewable Feedstock for Ethanol Biofuel Production. BioEnergy Research, 3(4), 328-334. https://doi.org/10.1007/s12155-010-9088-0

Abbasi, T., \& Abbasi, S. A. (2010, 2010/04/01/). Biomass energy and the environmental impacts associated with its production and utilization. Renewable and Sustainable Energy Reviews, 14(3), 919-937. https://doi.org/https://doi.org/10.1016/j.rser.2009.11.006

Aditiya, H. B., Mahlia, T. M. I., Chong, W. T., Nur, H., \& Sebayang, A. H. (2016, 2016/12/01/). Second generation bioethanol production: A critical review. Renewable and Sustainable Energy Reviews, 66, 631-653. https://doi.org/https://doi.org/10.1016/j.rser.2016.07.015

Ahlgren, S., Aronsson, P., Hansson, P.-A., Kimming, M., \& Lundkvist, H. (2011). Greenhouse gas emissions from cultivation of agricultural crops for biofuels and production of biogas from manure. S. U. o. A. Sciences.

https://pub.epsilon.slu.se/14114/1/ahlgren_et_al_170228.pdf

Alptekin, E., \& Canakci, M. (2008, 2008/12/01/). Determination of the density and the viscosities of biodiesel-diesel fuel blends. Renewable Energy, 33(12), 2623-2630. https://doi.org/https://doi.org/10.1016/j.renene.2008.02.020

Andrews, S. S. (2006). Crop Residue Removal for Biomass Energy Production: Effects on Soils and Recommendations. Retrieved 27-02 from https://www.nrcs.usda.gov/Internet/FSE_DOCUMENTS/nrcs142p2 053255.pdf

Auburger, S., Jacobs, A., Märländer, B., \& Bahrs, E. (2016, 2016/04/01/). Economic optimization of feedstock mix for energy production with biogas technology in Germany with a special focus on sugar beets - Effects on greenhouse gas emissions and energy balances. Renewable Energy, 89(Supplement C), 1-11. https://doi.org/https://doi.org/10.1016/j.renene.2015.11.042

Audsley, E., Stacey, K., Parsons, D. J., \& Williams, A. G. (2009). Estimation of the greenhouse gas emissions from agricultural pesticide manufacture and use. C. University.

https://dspace.lib.cranfield.ac.uk/bitstream/handle/1826/3913/Estimation of the greenhouse gas emissions from agricultural pesticide manufacture and us e-2009.pdf; jsessionid=C46EE7B1E955B8479071B3617364906B? sequence $=1$

Avinash, A., Subramaniam, D., \& Murugesan, A. (2014, 1//). Bio-diesel-A global scenario. Renewable and Sustainable Energy Reviews, 29, 517-527. https://doi.org/https://doi.org/10.1016/j.rser.2013.09.007

Azadi, P., Brownbridge, G., Mosbach, S., Smallbone, A., Bhave, A., Inderwildi, O., \& Kraft, M. (2014, 2014/01/01/). The carbon footprint and non-renewable energy demand of algae-derived biodiesel. Applied Energy, 113, 1632-1644. https://doi.org/https://doi.org/10.1016/j.apenergy.2013.09.027

Badger, P. C. (2002). Ethanol from cellulose: a general review Alexandria.

Baeyens, J., Kang, Q., Appels, L., Dewil, R., Lv, Y., \& Tan, T. (2015, 2015/04/01/). Challenges and opportunities in improving the production of bio-ethanol. Progress in Energy and Combustion Science, 47(Supplement C), 60-88. https://doi.org/https://doi.org/10.1016/j.pecs.2014.10.003 
Bang, C., Vitina, A., Gregg, J. S., \& Lindboe, H. H. (2013). Analysis of biomass prices: Future Danish prices for straw, wood chips and wood pellets "final report". E. E. Analysis. https://ens.dk/sites/ens.dk/files/Analyser/analysis of biomass prices 2013.06.1 $\underline{8 \text { - final report.pdf }}$

BASIS. (2015). Report on conversion efficiency of biomass: Version \#2. B. B. A. a. S. I. System). http://www.basisbioenergy.eu/fileadmin/BASIS/D3.5 Report on conversion ef ficiency of biomass.pdf

Batidzirai, B., Smeets, E. M. W., \& Faaij, A. P. C. (2012, 2012/12/01/). Harmonising bioenergy resource potentials-Methodological lessons from review of state of the art bioenergy potential assessments. Renewable and Sustainable Energy Reviews, 16(9), 6598-6630.

https://doi.org/https://doi.org/10.1016/j.rser.2012.09.002

Beer, J. (1988, October 01). Litter production and nutrient cycling in coffee (Coffea arabica) or cacao (Theobroma cacao) plantations with shade trees [journal article]. Agroforestry Systems, 7(2), 103-114. https://doi.org/10.1007/bf00046846

Bentsen, N. S., \& Felby, C. (2012, April 30). Biomass for energy in the European Union - a review of bioenergy resource assessments [journal article]. Biotechnology for Biofuels, 5(1), 25. https://doi.org/10.1186/1754-6834-5-25

Beringer, T., Lucht, W., \& Schaphoff, S. (2011). Bioenergy production potential of global biomass plantations under environmental and agricultural constraints. GCB Bioenergy, 3(4), 299-312. https://doi.org/doi:10.1111/j.1757-1707.2010.01088.x

Bernacchi, C. (2013). Impact of land use change due to bioenergy on regional hydrology (JRC84632). (Bioenergy and Water, Issue. J. R. C. o. t. E. Commission. http://waterfootprint.org/media/downloads/Leenes-et-al-2013 1.pdf

Bhandari, K. P., Collier, J. M., Ellingson, R. J., \& Apul, D. S. (2015, 7//). Energy payback time (EPBT) and energy return on energy invested (EROI) of solar photovoltaic systems: A systematic review and meta-analysis. Renewable and Sustainable Energy Reviews, 47, 133-141. https://doi.org/https://doi.org/10.1016/j.rser.2015.02.057

Bharathiraja, B., Jayamuthunagai, J., Sudharsanaa, T., Bharghavi, A., Praveenkumar, R., Chakravarthy, M., \& Yuvaraj, D. (2017, 2017/02/01/). Biobutanol - An impending biofuel for future: A review on upstream and downstream processing tecniques. Renewable and Sustainable Energy Reviews, 68, 788-807. https://doi.org/https://doi.org/10.1016/j.rser.2016.10.017

Bilandzija, N., Voca, N., Kricka, T., Matin, A., \& Jurisic, V. (2012). Energy potential of fruit tree pruned biomass in Croatia. Spanish Journal of Agricultural Research(2), 292-298. https://doi.org/http://dx.doi.org/10.5424/sjar/2012102-126-11

Bioenergy Europe. (2018). Biomass for energy: agrcultural residues E energy crops. https://bioenergyeurope.org/component/attachments/attachments.html?id=561 \&task=download

Biograce. (2015). Biograce-I GHG calculation tool: Production of Ethanol from Sugar beet Biograce. http://www.biograce.net/img/files/2015-05-12-161933BioGraceI GHG_calculation tool_-version 4d.zip

Bisaria, V. S., \& Ghose, T. K. (1981, 1981/04/01/). Biodegradation of cellulosic materials: Substrates, microorganisms, enzymes and products. Enzyme and Microbial 
Technology, 3(2), 90-104. https://doi.org/https://doi.org/10.1016/01410229(81)90066-1

Boddey, R. M., Soares, L. H. d. B., Alves, B. J. R., \& Urquiaga, S. (2008). Bio-Ethanol Production in Brazil. In D. Pimentel (Ed.), Biofuels, Solar and Wind as Renewable Energy Systems: Benefits and Risks (pp. 321-356). Springer Netherlands. https://doi.org/http://doi.org/10.1007/978-1-4020-8654-0_13

Bos-Brouwers, H. E. J., Langelaan, H. C., Sanders, J. P. M., Dijk, M. v., \& Vuuren, A. M. v. (2012). Chances for biomass: integrated valorisation of biomass resources. https://edepot.wur.nl/248864

Bos, J. F. F. P., Smit, A. L., \& Schröder, J. J. (2013, 2013/11/01/). Is agricultural intensification in The Netherlands running up to its limits? NJAS - Wageningen Journal of Life Sciences, 66, 65-73. https://doi.org/https://doi.org/10.1016/j.njas.2013.06.001

Brondani, M., Hoffmann, R., Mayer, F. D., \& Kleinert, J. S. (2015, January 01). Environmental and energy analysis of biodiesel production in Rio Grande do Sul, Brazil [journal article]. Clean Technologies and Environmental Policy, 17(1), 129-143. https://doi.org/http://doi.org/10.1007/s10098-014-0768-x

Cai, H., Han, J., Elgowainy, A., \& Wang, M. (2015). Research Note: Parameters of Canola Biofuel Production Pathways in GREET. A. N. Laboratory. https://greet.es.anl.gov/files/canadian-canola

Castellani, V., \& Sala, S. (2012, 2012/05/01/). Ecological Footprint and Life Cycle Assessment in the sustainability assessment of tourism activities. Ecological Indicators, 16, 135-147. https://doi.org/https://doi.org/10.1016/j.ecolind.2011.08.002

CCC. (2017). Seeding Rate. Canola Council of Canada. Retrieved March 18, 2019 from https://www.canolacouncil.org/canola-encyclopedia/plantestablishment/seeding-rate/

Chen, H., \& Chen, G. Q. (2011, 2011/05/01/). Energy cost of rapeseed-based biodiesel as alternative energy in China. Renewable Energy, 36(5), 1374-1378. https://doi.org/https://doi.org/10.1016/j.renene.2010.11.026

Cherubini, F., Bird, N. D., Cowie, A., Jungmeier, G., Schlamadinger, B., \& WoessGallasch, S. (2009). Energy- and greenhouse gas-based LCA of biofuel and bioenergy systems: Key issues, ranges and recommendations [Article]. Resources, Conservation and Recycling, 53(8), 434-447. https://doi.org/http://doi.org/10.1016/j.resconrec.2009.03.013

CIRCE. (2014). D3.1. Mapping and analysis of the pruning biomass potential in Europe. EuroPruning. http://www.europruning.eu/web/lists/pubfiles.aspx?type=pubdeliverables

Croezen, H. J., Bergsma, G. C., Otten, M. J. J., \& van Valkengoed, M. P. J. (2010). Biofuels: indirect land use change and climate impact. C. Delft. https://www.ce.nl/publicaties/download/944

Čuček, L., Klemeš, J. J., Varbanov, P. S., \& Kravanja, Z. (2015, December 01). Significance of environmental footprints for evaluating sustainability and security of development [journal article]. Clean Technologies and Environmental Policy, 17(8), 2125-2141. https://doi.org/http://doi.org/10.1007/s10098-015-0972-3 
Daioglou, V., Stehfest, E., Wicke, B., Faaij, A., \& van Vuuren, D. P. (2016). Projections of the availability and cost of residues from agriculture and forestry. GCB Bioenergy, 8(2), 456-470. https://doi.org/10.1111/gcbb.12285

Dalgaard, T., Halberg, N., \& Porter, J. R. (2001, 2001/10/01/). A model for fossil energy use in Danish agriculture used to compare organic and conventional farming. Agriculture, Ecosystems E Environment, 87(1), 51-65. https://doi.org/https://doi.org/10.1016/S0167-8809(00)00297-8

Davis, S. C., Dohleman, F. G., \& Long, S. P. (2011). The global potential for Agave as a biofuel feedstock. GCB Bioenergy, 3(1), 68-78. https://doi.org/10.1111/j.1757$\underline{1707.2010 .01077 . x}$

de Castro, C., Carpintero, Ó., Frechoso, F., Mediavilla, M., \& de Miguel, L. J. (2014, 2014/01/01/). A top-down approach to assess physical and ecological limits of biofuels. Energy, 64(Supplement C), 506-512. https://doi.org/https://doi.org/10.1016/j.energy.2013.10.049

de Fraiture, C., Giordano, M., \& Liao, Y. (2008). Biofuels and implications for agricultural water use: blue impacts of green energy. Water Policy, 10(S1), 67-81.

de Vries, S. C., van de Ven, G. W. J., van Ittersum, M. K., \& Giller, K. E. (2010, 2010/05/01/). Resource use efficiency and environmental performance of nine major biofuel crops, processed by first-generation conversion techniques. Biomass and Bioenergy, 34(5), 588-601. https://doi.org/https://doi.org/10.1016/j.biombioe.2010.01.001

de Wild-Scholten, M. J. (2013, 2013/12/01/). Energy payback time and carbon footprint of commercial photovoltaic systems. Solar Energy Materials and Solar Cells, 119, 296-305. https://doi.org/http://dx.doi.org/10.1016/j.solmat.2013.08.037

Di Blasi, C., Tanzi, V., \& Lanzetta, M. (1997, 1997/01/01/). A study on the production of agricultural residues in Italy. Biomass and Bioenergy, 12(5), 321-331. https://doi.org/https://doi.org/10.1016/S0961-9534(96)00073-6

Di Giacomo, G., \& Taglieri, L. (2009, 2009/05/01/). Renewable energy benefits with conversion of woody residues to pellets. Energy, 34(5), 724-731. https://doi.org/https://doi.org/10.1016/j.energy.2008.08.010

Dias De Oliveira, M. E., Vaughan, B. E., \& Rykiel, E. J. (2005). Ethanol as Fuel: Energy, Carbon Dioxide Balances, and Ecological Footprint. Bioscience, 55(7), 593-602. https://doi.org/http://doi.org/10.1641/00063568(2005)055[0593:EAFECD]2.0.CO;2

Djumaboev, K., Yuldashev, T., Holmatov, B., \& Gafurov, Z. (2019). Assessing Water Use, Energy Use And Carbon Emissions In Lift- Irrigated Areas: A Case Study From Karshi Steppe In Uzbekistan. Irrigation and Drainage, 68(3), 409-419. https://doi.org/10.1002/ird.2321

Dominguez-Faus, R., Powers, S. E., Burken, J. G., \& Alvarez, P. J. (2009, May 01). The water footprint of biofuels: a drink or drive issue? Environ Sci Technol, 43(9), 3005-3010. https://doi.org/http://doi.org/10.1021/es802162x

Donke, A., Nogueira, A., Matai, P., \& Kulay, L. (2017). Environmental and Energy Performance of Ethanol Production from the Integration of Sugarcane, Corn, and Grain Sorghum in a Multipurpose Plant. Resources, 6(1), 1. https://doi.org/https://doi.org/10.3390/resources6010001 
Dornburg, V., van Vuuren, D., van de Ven, G., Langeveld, H., Meeusen, M., Banse, M., van Oorschot, M., Ros, J., van den Born, G. J., \& Aiking, H. (2010). Bioenergy revisited: key factors in global potentials of bioenergy. Energy $\mathcal{E}$ Environmental Science, 3(3), 258-267.

EC. (2007). Reference Document on Best Available Techniques for the Manufacture of Large Volume Inorganic Chemicals - Ammonia, Acids and Fertilisers (Integrated Pollution Prevention and Control, Issue. E. Commission.

http://eippcb.jrc.ec.europa.eu/reference/BREF/lvic aaf.pdf

Edenhofer, O., Pichs-Madruga, R., Sokona, Y., Seyboth, K., Matschoss, P., Kadner, S., Zwickel, T., Eickemeier, P., Hansen, G., \& Schlömer, S. (2011). IPCC special report on renewable energy sources and climate change mitigation. Prepared By Working Group III of the Intergovernmental Panel on Climate Change, Cambridge University Press, Cambridge, UK.

Edwards, R., Padella, M., Giuntoli, J., Koeble, R., O'Connell, A., Bulgheroni, C., \& Marelli, L. (2017). Definition of input data to assess GHG default emissions from biofuels in EU legislation (JRC104483). JRC.

https://ec.europa.eu/jrc/en/publication/eur-scientific-and-technical-researchreports/definition-input-data-assess-ghg-default-emissions-biofuels-eulegislation-version-1c-july

EEA. (2006). How much bioenergy can Europe produce without harming the environment? European Environment Agency.

https://www.eea.europa.eu/publications/eea report 20067

EEA. (2016). Energy efficiency. European Environment Agency. Retrieved March 18, 2019 from https://www.eea.europa.eu/publications/ENVISSUENo12/page027.html

Eggleston, S., Buendia, L., Miwa, K., Ngara, T., \& Tanabe, K. (2006). 2006 IPCC Guidelines for National Greenhouse Gas Inventories. I. P. o. C. Change. https://www.ipccnggip.iges.or.jp/public/2006gl/

Eisentraut, A. (2010). Sustainable production of second-generation biofuels: Potential and perspectives in major economies and developing countries. I. E. Agency.

https://www.iea.org/publications/freepublications/publication/second generati on biofuels.pdf

Elbehri, A., Segerstedt, A., \& Liu, P. (2013). Biofuels and the sustainability challenge: a global assessment of sustainability issues, trends and policies for biofuels and related feedstocks. Food and Agriculture Organization of the United Nations (FAO).

ePure. (2017). European renewable ethanol - key figures 2017. EPure. Retrieved August 25 from https://epure.org/media/1763/180905-def-data-epure-statistics-2017designed-version.pdf

Ericsson, K., \& Nilsson, L. J. (2006, 2006/01/01/). Assessment of the potential biomass supply in Europe using a resource-focused approach. Biomass and Bioenergy, 30(1), 1-15. https://doi.org/https://doi.org/10.1016/j.biombioe.2005.09.001

European Commission. (2017). Proposal for a Directive of the European Parliament and of the Council on the promotion of the use of energy from renewable sources (recast).

Retrieved March 18, 2019 from https://eur-lex.europa.eu/legalcontent/EN/TXT/HTML/?uri=CELEX:52016PC0767R(01)\&from=EN

European Commission. (2018). Directive (EU) 2018/2001 of the European Parliament and of the Council of 11 December 2018 on the promotion of the use of energy from renewable 
sources (recast). https://eur-lex.europa.eu/legal-

content/EN/TXT/?uri=uriserv:OJ.L .2018.328.01.0082.01.ENG\&toc=OJ:L:2018:32

$\underline{\text { 8:TOC }}$

Eurostat. (2017). Main annual crop statistics: statistics explained.

https://ec.europa.eu/eurostat/statistics-explained/pdfscache/28946.pdf

Eurostat. (2019a). Annual crop statistics.

https://ec.europa.eu/eurostat/cache/metadata/Annexes/apro cp esms an1.pdf

Eurostat. (2019b). Electricity prices for household consumers - bi-annual data (from 2007

onwards). Eurostat. Retrieved August 20 from

https://appsso.eurostat.ec.europa.eu/nui/submitViewTableAction.do

Eurostat. (2019c). Eurostat: Agricultural prices and price indices (t_apri)

https://ec.europa.eu/eurostat/data/database

Eurostat. (2019d). Eurostat: Crop production in EU standard humidity (apro_cpsh1)

https://ec.europa.eu/eurostat/data/database

Eurostat. (2019). Energy Balances in the MS Excel file format (2019 edition). Eurostat.

Retrieved August 26 from

https:/ec.europa.eu/eurostat/web/energy/data/energy-balances

Evans, A., Strezov, V., \& Evans, T. J. (2010, 2010/06/01/). Sustainability considerations for electricity generation from biomass. Renewable and Sustainable Energy Reviews, 14(5), 1419-1427. https://doi.org/https://doi.org/10.1016/j.rser.2010.01.010

Fang, K., Heijungs, R., \& de Snoo, G. R. (2014, Jan). Theoretical exploration for the combination of the ecological, energy, carbon, and water footprints: Overview of a footprint family. Ecological Indicators, 36, 508-518.

https://doi.org/http://doi.org/10.1016/j.ecolind.2013.08.017

FAO. (2004). Fertilizer Consumption by Crop (Fertilizer use by crop in Brazil, Issue. F. a. A.

O. o. t. U. Nations. http://www.fao.org/docrep/007/y5376e/y5376e0a.htm\#bm10

FAO. (2006). Introducing the International Bioenergy Platform (IBEP). F. a. A. O. o. t. U.

Nations. http://cebem.org/cmsfiles/publicaciones/IntroducingIBEP.pdf

FAO. (2018). FAOSTAT: Crops Food and Agriculture Organization of the United Nations.

Retrieved July 27, 2017 from http://www.fao.org/faostat/en/\#data/QC

FAO. (2019). FAOSTAT: Land Use. Retrieved March 27, 2019 from

http://www.fao.org/faostat/en/\#data/RL

FAO. (Nd). Technical Conversion Factors for Agricultural Commodities. F. a. A. O. o. t. U.

Nations.

http://www.fao.org/fileadmin/templates/ess/documents/methodology/tcf.pdf

FAO, \& EBRD. (2017). Sustainable bioenergy options from crop and livestock residues: Egypt, Turkey and Ukraine. F. a. A. O. o. t. U. Nations. http://www.fao.org/3/ai8150e.pdf

FAOSTAT. (2020, March 11, 2020). FAOSTAT Statistical Database. Food and Agriculture Organization of the United Nations. . Retrieved March 3, 2020 from http://www.fao.org/faostat/en/\#home

Fargione, J., Hill, J., Tilman, D., Polasky, S., \& Hawthorne, P. (2008). Land Clearing and the Biofuel Carbon Debt. Science, 319(5867), 1235-1238.

https://doi.org/http://doi.org/10.1126/science.1152747 
Fernandes, U., \& Costa, M. (2010, 2010/05/01/). Potential of biomass residues for energy production and utilization in a region of Portugal. Biomass and Bioenergy, 34(5), 661-666. https://doi.org/https://doi.org/10.1016/j.biombioe.2010.01.009

Fernandez-Cornejo, J., Nehring, R., Osteen, C., Wechsler, S., Martin, A., \& Vialou, A. (2014). Pesticide Use in U.S. Agriculture: 21 Selected Crops, 1960-2008 (Economic Information Bulletin Number 124, Issue. U. S. D. o. Agriculture.

https://www.ers.usda.gov/webdocs/publications/43854/46734 eib124.pdf? v=418 $\underline{30}$

Fertilizers Europe. (2000). Production of Ammonia. F. Europe.

http://fertilizerseurope.com/fileadmin/user upload/publications/tecnical public ations/BATs/Booklet 1 final.pdf

Fertilizers Europe. (2019). Carbon Footprint Reference Values: energy efficiency and greenhouse gas emissions in European mineral fertilizer production and use. F. Europe.

https://www.fertilizerseurope.com/fileadmin/user upload/publications/agricult ure publications/carbon footprint web V4.pdf

FHWA. (2018). Average Annual Miles per Driver by Age Group. United States Department of Transportation - Federal Highway Administration. Retrieved June 12 from https://www.fhwa.dot.gov/ohim/onh00/bar8.htm

Fischer, G., Hizsnyik, E., Prieler, S., and van Velthuizen, H. (2007). Assessment of biomass potentials for biofuel feedstock production in Europe: Methodology and results. IIASA. https://ec.europa.eu/energy/intelligent/projects/sites/ieeprojects/files/projects/documents/refuel assessment of biomass_potentials.pdf

Fischer, G., Prieler, S., van Velthuizen, H., Berndes, G., Faaij, A., Londo, M., \& de Wit, M. (2010, Feb). Biofuel production potentials in Europe: Sustainable use of cultivated land and pastures, Part II: Land use scenarios. Biomass $\mathcal{E}$ Bioenergy, 34(2), 173-187. https://doi.org/10.1016/j.biombioe.2009.07.009

Fischer, G., \& Schrattenholzer, L. (2001, 2001/03/01/). Global bioenergy potentials through 2050. Biomass and Bioenergy, 20(3), 151-159.

https://doi.org/https://doi.org/10.1016/S0961-9534(00)00074-X

Fore, S. R., Porter, P., \& Lazarus, W. (2011, 2011/05/01/). Net energy balance of smallscale on-farm biodiesel production from canola and soybean. Biomass and Bioenergy, 35(5), 2234-2244.

https://doi.org/https://doi.org/10.1016/j.biombioe.2011.02.037

Fossum, J.-P. (2014). Calculation of Carbon Footprint of Fertilizer Production. YARA. Retrieved March 18, 2019 from

https://www.researchgate.net/profile/Anoop_Srivastava7/post/Can anyone_su ggest_me Black_CarbonBC_emission_factors for_chemical_fertilizer_producti on/attachment/5a7890044cde266d5888eab0/AS\%3A590722503806981\%40151785 0628849/download/2013 Carbon+footprint+of+AN++Laskumenetelm\%C3\%A4+-+Method+of+calculation tcm431-123924.pdf

Franzese, O. (2011). Effect of Weight and Roadway Grade on the Fuel Economy of Class-8 Freight Trucks. O. R. N. Laboratory. https://info.ornl.gov/sites/publications/files/Pub33386.pdf

Fritsche, U. R., Hennenberg, K. J., Wiegeman, K., Herrera, R., Franke, B., Koppen, S., Reinhardt, G., Dornburg, V., Faaij, A., \& Smeets, E. (2010). Bioenergy 
Environmental Impact Analysis (BIAS): Analytical Framework (46). (Environment and Natural Resources Management Issue. F. a. A. O. o. t. U. Nations.

http://www.fao.org/3/a-am303e.pdf

Gallagher, P. W., Dikeman, M., Fritz, J., Wailes, E. J., Gauthier, W. M., \& Shapouri, H. (2003). Biomass from crop residues: cost and supply estimates.

Galli, A., Wiedmann, T., Ercin, E., Knoblauch, D., Ewing, B., \& Giljum, S. (2012, May). Integrating Ecological, Carbon and Water footprint into a "Footprint Family" of indicators: Definition and role in tracking human pressure on the planet. Ecological Indicators, 16, 100-112. https://doi.org/http://doi.org/10.1016/j.ecolind.2011.06.017

García-Galindo, D., Dyjakon, A., \& Cay Villa-Ceballos, F. (2019). Building Variable Productivity Ratios for Improving Large Scale Spatially Explicit Pruning Biomass Assessments. Energies, 12(5), 957. https://www.mdpi.com/1996$\underline{1073 / 12 / 5 / 957}$

Gellings, C. W., \& Parmenter, K. E. (2004). Energy efficiency in fertilizer production and use. In C. W. Gellings \& K. Blok (Eds.), Encyclopedia of Life Support Systems (EOLSS). EOLSS Publishers. http://www.eolss.net/ebooks/sample\%20chapters/c08/e3-18-04-03.pdf

Gerbens-Leenes, P. W., \& Hoekstra, A. Y. (2013). Water footprint quantification of energy at a global level (JRC84632). (Bioenergy and Water, Issue. J. R. C. o. t. E. Commission. http://waterfootprint.org/media/downloads/Leenes-et-al2013 1.pdf

Gerbens-Leenes, P. W., van Lienden, A. R., Hoekstra, A. Y., \& van der Meer, T. H. (2012, Aug). Biofuel scenarios in a water perspective: The global blue and green water footprint of road transport in 2030. Global Environmental Change, 22(3), 764-775. https://doi.org/http://doi.org/10.1016/j.gloenvcha.2012.04.001

Gerbens-Leenes, P. W., Xu, L., de Vries, G. J., \& Hoekstra, A. Y. (2014, Nov). The blue water footprint and land use of biofuels from algae. Water Resources Research, 50(11), 8549-8563. https://doi.org/http://doi.org/10.1002/2014wr015710

Gerbens-Leenes, W., \& Hoekstra, A. Y. (2011, Aug). The water footprint of biofuel-based transport [10.1039/C1EE01187A]. Energy \& Environmental Science, 4(8), 26582668. https://doi.org/http://doi.org/10.1039/c1ee01187a

Gerbens-Leenes, W., \& Hoekstra, A. Y. (2012, Apr). The water footprint of sweeteners and bio-ethanol. Environment International, 40, 202-211. https://doi.org/http://doi.org/10.1016/j.envint.2011.06.006

Gerbens-Leenes, W., Hoekstra, A. Y., \& van der Meer, T. (2009a, Feb 15). The water footprint of energy from biomass: A quantitative assessment and consequences of an increasing share of bio-energy in energy supply. Ecological Economics, 68(4), 1052-1060. https://doi.org/http://doi.org/10.1016/j.ecolecon.2008.07.013

Gerbens-Leenes, W., Hoekstra, A. Y., \& van der Meer, T. H. (2009b, Jun 23). The water footprint of bioenergy. Proceedings of the National Academy of Sciences of the United States of America, 106(25), 10219-10223. https://doi.org/http://doi.org/10.1073/pnas.0812619106

German, L., \& Bauen, A. (2018). D 6.3: Revised Energy Balance and GHG Assessment. Butanext. http://butanext.eu/contents/publicdeliverables/butanext-deliverabled6-3-ghg-assessment-finalv12.pdf 
Giampietro, M., Mayumi, K., \& Sorman Hadiye, A. (2010). Assessing the quality of alternative energy sources: Energy Return On the Investment (EROI), the metabolic pattern of societies and energy statistics. I. d. C. i. T. Ambientals. https://ddd.uab.cat/record/54888

Giampietro, M., \& Ulgiati, S. (2005, 2005/09/01). Integrated Assessment of Large-Scale Biofuel Production. Critical Reviews in Plant Sciences, 24(5-6), 365-384. https://doi.org/http://doi.org/10.1080/07352680500316300

Gregg, J. S., \& Izaurralde, R. C. (2010, 2010/01/01). Effect of crop residue harvest on longterm crop yield, soil erosion and nutrient balance: trade-offs for a sustainable bioenergy feedstock. Biofuels, 1(1), 69-83. https://doi.org/10.4155/bfs.09.8

Grella, M., Manzone, M., Gioelli, F., \& Balsari, P. (2013). Harvesting orchard pruning residues in southern Piedmont: a first evaluation of biomass production and harvest loss. Journal of Agricultural Engineering, 44(3), 97-102.

Grübler, A. (1996). Time for a Change: On the Patterns of Diffusion of Innovation. Daedalus, 125(3), 19-42. www.jstor.org/stable/20027369

Gupta, A., \& Verma, J. P. (2015, 2015/01/01/). Sustainable bio-ethanol production from agro-residues: A review. Renewable and Sustainable Energy Reviews, 41(Supplement C), 550-567. https://doi.org/https://doi.org/10.1016/j.rser.2014.08.032

Hall, C. A., Balogh, S., \& Murphy, D. J. (2009). What is the minimum EROI that a sustainable society must have? Energies, 2(1), 25-47.

Harmsen, P. F. H., Hackmann, M. M., \& Bos, H. L. (2014). Green building blocks for biobased plastics. Biofuels, Bioproducts and Biorefining, 8(3), 306-324. https://doi.org/10.1002/bbb.1468

Hassan, S. S., Williams, G. A., \& Jaiswal, A. K. (2018, 2018/08/01/). Emerging technologies for the pretreatment of lignocellulosic biomass. Bioresource Technology, 262, 310318. https://doi.org/https://doi.org/10.1016/j.biortech.2018.04.099

Hendriks, A. T. W. M., \& Zeeman, G. (2009, 2009/01/01/). Pretreatments to enhance the digestibility of lignocellulosic biomass. Bioresource Technology, 100(1), 10-18. https://doi.org/https://doi.org/10.1016/j.biortech.2008.05.027

Hengsdijk, H. (2018). Project: SMP-18012 Costa Rica pineapple residue valorisation. Wageningen University \& Research. Retrieved April 5, 2019 from https://www.wur.nl/nl/Onderzoek-Resultaten/OnderzoeksprojectenLNV/Expertisegebieden/kennisonline/SMP-18012-Costa-Rica-pineappleresidue-valorisation-.htm

Hill, J., Nelson, E., Tilman, D., Polasky, S., \& Tiffany, D. (2006, July 25, 2006). Environmental, economic, and energetic costs and benefits of biodiesel and ethanol biofuels. Proceedings of the National Academy of Sciences of the United States of America, 103(30), 11206-11210. https://doi.org/http://doi.org/10.1073/pnas.0604600103

Hiloidhari, M., Das, D., \& Baruah, D. C. (2014, 2014/04/01/). Bioenergy potential from crop residue biomass in India. Renewable and Sustainable Energy Reviews, 32, 504512. https://doi.org/https://doi.org/10.1016/j.rser.2014.01.025

HLPE. (2013). Biofuels and food security. A report by the High Level Panel of Experts on Food Security and Nutrition of the Committee on World Food Security (5). (High Level Panel of Experts, Issue. F. a. A. O. o. t. U. Nations. 
http://www.fao.org/fileadmin/user_upload/hlpe/hlpe_documents/HLPE_Repor ts/HLPE-Report-5 Biofuels and food security.pdf

Hoekstra, A. Y. (2017). Water Footprint Assessment in Supply Chains. In Y. Bouchery, C. J. Corbett, J. C. Fransoo, \& T. Tan (Eds.), Sustainable Supply Chains: A ResearchBased Textbook on Operations and Strategy (pp. 65-85). Springer International Publishing. https://doi.org/10.1007/978-3-319-29791-0 4

Hoekstra, A. Y. (2019, 2019/07/01/). Green-blue water accounting in a soil water balance. Advances in Water Resources, 129, 112-117. https://doi.org/https://doi.org/10.1016/j.advwatres.2019.05.012

Hoekstra, A. Y., Chapagain, A. K., Aldaya, M. M., \& Mekonnen, M. M. (2011). The water footprint assessment manual: Setting the global standard. Earthscan.

Hoekstra, A. Y., \& Mekonnen, M. M. (2012, Feb 28). The water footprint of humanity. Proceedings of the National Academy of Sciences of the United States of America, 109(9), 3232-3237. https://doi.org/http://doi.org/10.1073/pnas.1109936109

Hoekstra, A. Y., \& Wiedmann, T. O. (2014, Jun 06). Humanity's unsustainable environmental footprint. Science, 344(6188), 1114-1117. https://doi.org/http://doi.org/10.1126/science.1248365

Hogeboom, R. J., Knook, L., \& Hoekstra, A. Y. (2018, 2018/03/01/). The blue water footprint of the world's artificial reservoirs for hydroelectricity, irrigation, residential and industrial water supply, flood protection, fishing and recreation. Advances in Water Resources, 113, 285-294.

https://doi.org/https://doi.org/10.1016/j.advwatres.2018.01.028

Holmatov, B., \& Hoekstra, A. Y. (2020a). Data for - The environmental footprint of transport by car using renewable energy Zenodo. https://doi.org/http://doi.org/10.5281/zenodo.3600242

Holmatov, B., \& Hoekstra, A. Y. (2020b). Data for - The environmental footprint of transport by car using renewable energy [Data set]. Earth's Future. . http://doi.org/10.5281/zenodo.3600242

Holmatov, B., \& Hoekstra, A. Y. (2020c). The Environmental Footprint of Transport by Car Using Renewable Energy. Earth's Future, 8(2), e2019EF001428. https://doi.org/10.1029/2019ef001428

Holmatov, B., Hoekstra, A. Y., \& Krol, M. S. (2019, 2019/09/01/). Land, water and carbon footprints of circular bioenergy production systems. Renewable and Sustainable Energy Reviews, 111, 224-235. https://doi.org/https://doi.org/10.1016/j.rser.2019.04.085

Hoogwijk, M., Faaij, A., van den Broek, R., Berndes, G., Gielen, D., \& Turkenburg, W. $(2003,2003 / 08 / 01 /)$. Exploration of the ranges of the global potential of biomass for energy. Biomass and Bioenergy, 25(2), 119-133. https://doi.org/https://doi.org/10.1016/S0961-9534(02)00191-5

Hosseinkhani, H., Euring, M., \& Kharazipour, A. (2014). Utilization of date palm (Phoenix dactylifera L.) pruning residues as raw material for MDF manufacturing. Journal of Materials Science Research, 4(1).

Humbird, D., Davis, R., Tao, L., Kinchin, C., Hsu, D., Aden, A., Schoen, P., Lukas, J., Olthof, B., \& Worley, M. (2011). Process design and economics for biochemical conversion of lignocellulosic biomass to ethanol: dilute-acid pretreatment and enzymatic hydrolysis of corn stover. https://www.nrel.gov/docs/fy11osti/47764.pdf 
Huzir, N. M., Aziz, M. M. A., Ismail, S. B., Abdullah, B., Mahmood, N. A. N., Umor, N. A., \& Syed Muhammad, S. A. F. a. (2018, 2018/10/01/). Agro-industrial waste to biobutanol production: Eco-friendly biofuels for next generation. Renewable and Sustainable Energy Reviews, 94, 476-485.

https://doi.org/https://doi.org/10.1016/j.rser.2018.06.036

ICIS. (2017). Europe fuel ethanol spot price lifts amid tight prompt supply. ICIS. Retrieved August 8 from

https://www.icis.com/explore/resources/news/2017/07/12/10123602/europe-fuelethanol-spot-price-lifts-amid-tight-prompt-supply/

IEA. (2011). Biofuels for Transport (Technology Roadmap, Issue. I. E. Agency. https://www.iea.org/publications/freepublications/publication/Biofuels Roadm ap WEB.pdf

IEA. (2015a). Electricity Information (IEA Statistics, Issue. I. E. Agency. https://www.oecdilibrary.org/docserver/electricity-2015-

en.pdf?expires=1531561367\&id=id\&accname=id11881\&checksum=3EEF04EBE9 C6C39049197AE653768FE5

IEA. (2015b). Energy and Climate Change (World Energy Outlook Special Report, Issue. I. E. Agency.

https://www.iea.org/publications/freepublications/publication/WEO2015Special ReportonEnergyandClimateChange.pdf

IEA. (2016a). $2016 \mathrm{CO}_{2}$ emissions from fuel combustion: highlights. I. E. Agency. https://emis.vito.be/sites/emis.vito.be/files/articles/3331/2016/CO2Emissionsfro mFuelCombustion_Highlights 2016.pdf

IEA. (2016b). Key World Energy Statistics. I. E. Agency.

https://www.ourenergypolicy.org/wp-

content/uploads/2016/09/KeyWorld2016.pdf

IEA. (2016c). World Energy Outlook 2016. I. E. Agency. https://webstore.iea.org/worldenergy-outlook-2016

IEA. (2017a). Delivering Sustainable Bioenergy (Technology Roadmap, Issue. I. E. Agency. http://www.iea.org/publications/freepublications/publication/Technology Roa dmap_Delivering_Sustainable_Bioenergy.pdf

IEA. (2017b). The Future of Trucks: Implications for energy and the environment. I. E. Agency. https://www.iea.org/publications/freepublications/publication/TheFutureofTru cksImplicationsforEnergyand theEnvironment.pdf

IEA. (2017c). World Energy Outlook 2017. I. E. Agency. https://www.iea.org/weo2017/

IEA. (2018a). $2018 \mathrm{CO}_{2}$ emissions from fuel combustion: Highlights. I. E. Agency.

http://www.indiaenvironmentportal.org.in/files/file/CO2 Emissions_from_Fuel Combustion 2018 Highlights.pdf

IEA. (2018b). Renewables 2018: Analysis and Forecasts to 2023. IEA.

https://webstore.iea.org/download/direct/2322

IEA. (2018c). World: Balances for 2014. International Energy Agency. Retrieved January 28, 2018 from

https://www.iea.org/statistics/statisticssearch/report/?year=2014\&country=WO

RLD\&product=Balances

IEA. (2018d). World: Oil for 2014. International Energy Agency. Retrieved January 28,

2018 from 
https://www.iea.org/statistics/statisticssearch/report/?year=2014\&country=WO $\underline{\text { RLD\&product }=\text { Oil }}$

IEA. (2019a). $2019 \mathrm{CO}_{2}$ emissions from fuel combustion: highlights. I. E. Agency.

https://webstore.iea.org/co2-emissions-from-fuel-combustion-2019-highlights

IEA. (2019b). Biofuels for transport: Tracking clean energy progress. International Energy

Agency. Retrieved February 26, 2019 from

https://www.iea.org/tcep/transport/biofuels/

IEA. (2019c). Database on facilities for the production of advanced liquid and gaseous biofuels for transport. International Energy Agency. Retrieved February 19, 2019 from

https://demoplants.bioenergy2020.eu/index.html

IEA. (2019d). Global electricity generation mix by scenario, 2018, Stated Policies and

Sustainable Development Scenarios 2040. I. E. Agency. https://www.iea.org/data-

and-statistics/charts/global-electricity-generation-mix-by-scenario-2018-stated-

policies-and-sustainable-development-scenarios-2040

IEA. (2019e). Hydrogen: Tracking Clean Energy Progress. International Energy Agency.

Retrieved July 3, 2019 from

https://www.iea.org/tcep/energyintegration/hydrogen/

IEA. (2019f). Renewables information: Overview. I. E. Agency.

https://iea.blob.core.windows.net/assets/6959bcb0-d298-404c-80e1-

2afaa784798e/Renewables Information 2019 Overview.pdf

IEA. (2019g). Transport biofuels: tracking clean energy progress. International Energy

Agency. Retrieved August 25 from https://www.iea.org/tcep/transport/biofuels/

IEA. (2020a). Advanced Biofuels - Potential for Cost Reduction. I. Bioenergy.

https://www.ieabioenergy.com/publications/new-publication-advanced-

biofuels-potential-for-cost-reduction/

IEA. (2020b). Data and Statistics: Data browser. I. E. Agency. https://www.iea.org/data-

and-statistics/data-tables? country=WORLD\&energy=Balances\&year=2017

IEA. (2020c). Global CO2 emissions in 2019. International Energy Agency. Retrieved

February 17, 2020 from https://www.iea.org/articles/global-co2-emissions-in-

$\underline{2019}$

IEA. (2020d). Tracking Transport 2020. I. E. Agency. https://www.iea.org/reports/trackingtransport-2020

IEA, \& OECD. (2010). Energy Statistics Manual. I. E. Agency.

https://www.iea.org/training/toolsandresources/energystatisticsmanual/

IGES. (2020). IGES List of Grid Emission Factors. I. f. G. E. Strategies.

https://pub.iges.or.jp/pub/iges-list-grid-emission-factors

IPCC. (2018). Global warming of 1.5 C. https://www.ipcc.ch/sr15/

IRENA. (2016a). Innovation Outlook: Advanced Liquid Biofuels. I. R. E. Agency.

http://www.irena.org/-

Lmedia/Files/IRENA/Agency/Publication/2016/IRENA Innovation Outlook Ad vanced Liquid Biofuels 2016.pdf

IRENA. (2016b). Renewable Energy Targets. International Renewable Energy Agency.

Retrieved March 18, 2019 from

http://resourceirena.irena.org/gateway/dashboard/?q=renewable\%20energy $\% 20$

$\underline{\text { targets\&topic }=1021 \& \text { subTopic }=35}$ 
IRENA. (2018). Global Energy Transformation: A roadmap to 2050. I. R. E. Agency.

https://www.irena.org/-

Lmedia/Files/IRENA/Agency/Publication/2018/Apr/IRENA Report GET 2018.p $\underline{\mathrm{df}}$

IRENA. (2019a). Advanced biofuels: what holds them back? I. R. E. Agency.

https://www.irena.org/-

Lmedia/Files/IRENA/Agency/Publication/2019/Nov/IRENA Advanced-

biofuels 2019.pdf

IRENA. (2019b). Global energy transformation: A roadmap to 2050. I. R. E. Agency.

https://www.irena.org/publications/2019/Apr/Global-energy-transformation-Aroadmap-to-2050-2019Edition

IRENA. (2020). Renewable Energy Statistics 2020. International Renewable Energy Agency. Retrieved July 2, 2020 from https://irena.org/publications/2020/Jul/Renewableenergy-statistics-2020

IUSS, ISRIC, \& FAO. (2006). World reference base for soil resources 2006: a framework for international classification, correlation and communication (103). (World Soil

Resources Report, Issue. F. a. A. O. o. t. U. Nations. http://www.fao.org/3/aa0510e.pdf

Jia, L., Sun, Z., Ge, X., Xin, D., \& Zhang, J. (2013). Comparison of the delignifiability and hydrolysability of wheat straw and corn stover in aqueous ammonia pretreatment. BioResources, 8(3), 4505-4517.

Johansson, T. B., Patwardhan, A. P., Nakićenović, N., \& Gomez-Echeverri, L. (2012). Global energy assessment: toward a sustainable future. Cambridge University Press.

Jölli, D., \& Giljum, S. (2005). Unused biomass extraction in agriculture, forestry and fishery. SERI Studies, 3.

Karatzos, S., McMillan, J. D., \& Saddler, J. N. (2014). The Potential and Challenges of Dropin Biofuels (T39-T1). I. B. T. 39. http://task39.sites.olt.ubc.ca/files/2014/01/Task39-Drop-in-Biofuels-Report-FINAL-2-Oct-2014-ecopy.pdf

Kissel, D. K. (ND). Fertilizer Recommendations by Crops, Categorized. U. o. Georgia. http://aesl.ces.uga.edu/publications/soil/CropSheets.pdf

Koçar, G., \& Civaş, N. (2013, 2013/12/01/). An overview of biofuels from energy crops: Current status and future prospects. Renewable and Sustainable Energy Reviews, 28(Supplement C), 900-916. https://doi.org/https://doi.org/10.1016/j.rser.2013.08.022

Koffi, B., Cerutti, A. K., Duerr, M., Iancu, A., Kona, A., \& Janssens-Maenhout, G. (2017). Covenant of Mayors for Climate and Energy: Default emission factors for local emission inventories. JRC.

https://publications.jrc.ec.europa.eu/repository/bitstream/JRC107518/jrc technic al reports - com default emission factors-2017.pdf

Koopmans, A., \& Koppejan, J. (1997). Agricultural and Forest Residues - Generation, Utilization and Availability. F. a. A. O. o. t. U. Nations. http://www.fao.org/3/AD576E/ad576e00.pdf

Kraatz, S., Sinistore, J. C., \& Reinemann, D. J. (2013). Energy intensity and global warming potential of corn grain ethanol production in Wisconsin (USA). Food and Energy Security, 2(3), 207-219. https://doi.org/http://doi.org/10.1002/fes3.27 
Lal, R. (2005, 2005/05/01/). World crop residues production and implications of its use as a biofuel. Environment International, 31(4), 575-584.

https://doi.org/https://doi.org/10.1016/j.envint.2004.09.005

Liu, J., Zhao, D., Gerbens-Leenes, P. W., \& Guan, D. (2015, Jul 09). China's rising hydropower demand challenges water sector [Article]. Scientific Reports, 5, 11446. https://doi.org/http://doi.org/10.1038/srep11446

Liu, Q., Zhang, T., Liao, Y., Cai, C., Tan, J., Wang, T., Qiu, S., He, M., \& Ma, L. (2017, 2017/07/03). Production of C5/C6 Sugar Alcohols by Hydrolytic Hydrogenation of Raw Lignocellulosic Biomass over Zr Based Solid Acids Combined with $\mathrm{Ru} / \mathrm{C}$. ACS Sustainable Chemistry \& Engineering, 5(7), 5940-5950.

https://doi.org/10.1021/acssuschemeng.7b00702

Llevot, A., Dannecker, P.-K., von Czapiewski, M., Over, L. C., Söyler, Z., \& Meier, M. A. R. (2016). Renewability is not Enough: Recent Advances in the Sustainable Synthesis of Biomass-Derived Monomers and Polymers. Chemistry - A European Journal, 22(33), 11510-11521. https://doi.org/10.1002/chem.201602068

López-Bellido, L., Wery, J., \& López-Bellido, R. J. (2014, 2014/10/01/). Energy crops: Prospects in the context of sustainable agriculture. European Journal of Agronomy, 60, 1-12. https://doi.org/https://doi.org/10.1016/j.eja.2014.07.001

Louwen, A., van Sark, W. G. J. H. M., Faaij, A. P. C., \& Schropp, R. E. I. (2016, 2016/12/06). Re-assessment of net energy production and greenhouse gas emissions avoidance after 40 years of photovoltaics development. Nature Communications, 7(1), 13728. https://doi.org/10.1038/ncomms13728

Luo, L., van der Voet, E., Huppes, G., \& Udo de Haes, H. A. (2009, 2009/09/01). Allocation issues in LCA methodology: a case study of corn stover-based fuel ethanol. The International Journal of Life Cycle Assessment, 14(6), 529-539. https://doi.org/10.1007/s11367-009-0112-6

Lynd, L. R., Liang, X., Biddy, M. J., Allee, A., Cai, H., Foust, T., Himmel, M. E., Laser, M. S., Wang, M., \& Wyman, C. E. (2017, 2017/06/01/). Cellulosic ethanol: status and innovation. Current Opinion in Biotechnology, 45, 202-211. https://doi.org/https://doi.org/10.1016/j.copbio.2017.03.008

Macedo, I. C., Seabra, J. E. A., \& Silva, J. E. A. R. (2008, 2008/07/01/). Green house gases emissions in the production and use of ethanol from sugarcane in Brazil: The 2005/2006 averages and a prediction for 2020. Biomass and Bioenergy, 32(7), 582595. https://doi.org/https://doi.org/10.1016/j.biombioe.2007.12.006

Magagnotti, N., Pari, L., Picchi, G., \& Spinelli, R. (2013, 2013/01/01/). Technology alternatives for tapping the pruning residue resource. Bioresource Technology, 128, 697-702. https://doi.org/https://doi.org/10.1016/j.biortech.2012.10.149

Mathioudakis, V., Gerbens-Leenes, P. W., Van der Meer, T. H., \& Hoekstra, A. Y. (2017). The water footprint of second-generation bioenergy: A comparison of biomass feedstocks and conversion techniques. Journal of Cleaner Production, 148, 571582. https://doi.org/http://doi.org/10.1016/j.jclepro.2017.02.032

McGlade, J., Werner, B., Young, M., Matlock, M., Jefferies, D., Sonneman, G., MartinezAldaya, M., Pfister, S., Berger, M., \& Farell, C. (2012). Measuring water use in a green economy, a report of the working group on water efficiency to the International Resource Panel. United Nations Environment Programme. 
Mehmeti, A., Angelis-Dimakis, A., Arampatzis, G., McPhail, S., \& Ulgiati, S. (2018). Life Cycle Assessment and Water Footprint of Hydrogen Production Methods: From Conventional to Emerging Technologies. Environments, 5(2), 24. http://www.mdpi.com/2076-3298/5/2/24

Mekonnen, M. M., Gerbens-Leenes, P., \& Hoekstra, A. Y. (2015). The consumptive water footprint of electricity and heat: a global assessment. Environmental Science: Water Research \& Technology, 1(3), 285-297.

Mekonnen, M. M., Gerbens-Leenes, P. W., \& Hoekstra, A. Y. (2016, Nov 01). Future electricity: The challenge of reducing both carbon and water footprint. Science of the Total Environment, 569-570, 1282-1288.

https://doi.org/http://doi.org/10.1016/j.scitotenv.2016.06.204

Mekonnen, M. M., \& Hoekstra, A. Y. (2010). The green, blue and grey water footprint of crops and derived crops products.

Mekonnen, M. M., \& Hoekstra, A. Y. (2011). The green, blue and grey water footprint of crops and derived crop products. Hydrology and Earth System Sciences, 15(5), 1577-1600. https://doi.org/http://doi.org/10.5194/hess-15-1577-2011

Mekonnen, M. M., \& Hoekstra, A. Y. (2012). The blue water footprint of electricity from hydropower. Hydrology and Earth System Sciences, 16(1), 179-187.

https://doi.org/http://doi.org/10.5194/hess-16-179-2012

Mekonnen, M. M., Romanelli, T. L., Ray, C., Hoekstra, A. Y., Liska, A., \& Neale, C. M. U. (2018, 2018/11/14). Water, Energy, and Carbon Footprints of Bio-ethanol from the US and Brazil. Environmental Science \& Technology. https://doi.org/10.1021/acs.est.8b03359

Menon, V., \& Rao, M. (2012, 2012/08/01/). Trends in bioconversion of lignocellulose: Biofuels, platform chemicals \& biorefinery concept. Progress in Energy and Combustion Science, 38(4), 522-550. https://doi.org/https://doi.org/10.1016/j.pecs.2012.02.002

Milbrandt, A. (2009). Assessment of Biomass Resources in Liberia (NREL/TP-6A2-44808). N.

R. E. Laboratory. https://www.nrel.gov/docs/fy09osti/44808.pdf

Milbrandt, A., \& Overend, R. P. (2008). Survey of Biomass Resource Assessments and Assessment Capabilities in APEC Economies. NREL.

https://www.nrel.gov/docs/fy09osti/43710.pdf

Miller, L., \& Carriveau, R. (2017, 2017/04/15/). Balancing the carbon and water footprints of the Ontario energy mix. Energy, 125, 562-568.

https://doi.org/https://doi.org/10.1016/j.energy.2017.02.171

Monforti, F., Lugato, E., Motola, V., Bodis, K., Scarlat, N., \& Dallemand, J. F. (2015, 2015/04/01/). Optimal energy use of agricultural crop residues preserving soil organic carbon stocks in Europe. Renewable and Sustainable Energy Reviews, 44, 519-529. https://doi.org/https://doi.org/10.1016/j.rser.2014.12.033

Munoz Castillo, R., Feng, K., Hubacek, K., Sun, L., Guilhoto, J., \& Miralles-Wilhelm, F. (2017). Uncovering the Green, Blue, and Grey Water Footprint and Virtual Water of Biofuel Production in Brazil: A Nexus Perspective. Sustainability, 9(11), 2049.

Murphy, R., Woods, J., Black, M., \& McManus, M. (2011, 2011/01/01/). Global developments in the competition for land from biofuels. Food Policy, 36, S52-S61. https://doi.org/https://doi.org/10.1016/j.foodpol.2010.11.014 
Mussatto, S. I., Dragone, G., Guimarães, P. M. R., Silva, J. P. A., Carneiro, L. M., Roberto, I. C., Vicente, A., Domingues, L., \& Teixeira, J. A. (2010, 2010/11/01/).

Technological trends, global market, and challenges of bio-ethanol production. Biotechnology Advances, 28(6), 817-830.

https://doi.org/https://doi.org/10.1016/j.biotechadv.2010.07.001

Nagata, G. A., Souto, B. A., Perazzini, M. T. B., \& Perazzini, H. (2020, 2020/02/01/).

Analysis of the isothermal condition in drying of acai berry residues for biomass application. Biomass and Bioenergy, 133, 105453.

https://doi.org/https://doi.org/10.1016/j.biombioe.2019.105453

Nasdaq. (2020). EH CBOT Ethanol: Historical Data. Nasdaq. https://www.nasdaq.com/market-activity/commodities/eh

Nati, C., Boschiero, M., Picchi, G., Mastrolonardo, G., Kelderer, M., \& Zerbe, S. (2018, 2018/08/01/). Energy performance of a new biomass harvester for recovery of orchard wood wastes as alternative to mulching. Renewable Energy, 124, 121-128. https://doi.org/https://doi.org/10.1016/j.renene.2017.07.030

Nogueira, L. A. H. (2011, 2011/06/01/). Does biodiesel make sense? Energy, 36(6), 36593666. https://doi.org/https://doi.org/10.1016/j.energy.2010.08.035

Nonhebel, S. (2005, 2005/04/01/). Renewable energy and food supply: will there be enough land? Renewable and Sustainable Energy Reviews, 9(2), 191-201. https://doi.org/https://doi.org/10.1016/j.rser.2004.02.003

Nutrient. (2018). What is potash and where does it come from? Nutrient. Retrieved March 18, 2019 from https://www.nutrien.com/what-we-do/our-business/potash

O'Brien, D. M., Dumler, T. J., \& Jones, R. D. (2010). The Economics of Selling Crop Residue Biomass for Cellulosic Ethanol Production at the Farm Level (Selected Paper, Issue. http://ageconsearch.umn.edu/record/61649/files/2010\%20AAEA\%20Paper The \%20Economics $\% 20$ of $\% 20$ Selling $\% 20$ Crop $\% 20$ Residue $\% 20$ Biomass $\% 20$ OBrien \%20Dumler\%20Jones \%20May\%204\%202010.pdf

O'Connor, D. (2013). Advanced Biofuels - GHG Emissions and Energy Balances. I. B. T. 39. https://www.ieabioenergy.com/publications/advanced-biofuels-ghg-emissionsand-energy-balances/

OECD. (2004). Biomass and Agriculture. https://doi.org/doi:https://doi.org/10.1787/9789264105546-en

OECD. (2015). Carbon intensity of electricity generation. https://doi.org/doi:https://doi.org/10.1787/9789264238787-graph12-en

Offermann, R., Seidenberger, T., Thrän, D., Kaltschmitt, M., Zinoviev, S., \& Miertus, S. (2011, 2011/01/01). Assessment of global bioenergy potentials. Mitigation and Adaptation Strategies for Global Change, 16(1), 103-115. https://doi.org/10.1007/s11027-010-9247-9

Oh, Y.-K., Hwang, K.-R., Kim, C., Kim, J. R., \& Lee, J.-S. (2018, 2018/06/01/). Recent developments and key barriers to advanced biofuels: A short review. Bioresource Technology, 257, 320-333. https://doi.org/https://doi.org/10.1016/j.biortech.2018.02.089

OICA. (2019a). Production Statistics. International Organization of Motor Vehicle Manufacturers. Retrieved May 20 from http://www.oica.net/production$\underline{\text { statistics/ }}$ 
OICA. (2019b). World Vehicles in Use - All Vehicles. International Organization of Motor

Vehicle Manufacturers. Retrieved May 20 from http://www.oica.net/wpcontent/uploads/Total in-use-All-Vehicles.pdf

Okadera, T., Chontanawat, J., \& Gheewala, S. H. (2014, 2014/12/01/). Water footprint for energy production and supply in Thailand. Energy, 77, 49-56. https://doi.org/http://dx.doi.org/10.1016/j.energy.2014.03.113

Okello, C., Pindozzi, S., Faugno, S., \& Boccia, L. (2013, 2013/09/01/). Bioenergy potential of agricultural and forest residues in Uganda. Biomass and Bioenergy, 56, 515-525. https://doi.org/https://doi.org/10.1016/j.biombioe.2013.06.003

Pacetti, T., Lombardi, L., \& Federici, G. (2015, 2015/08/15/). Water-energy Nexus: a case of biogas production from energy crops evaluated by Water Footprint and Life Cycle Assessment (LCA) methods. Journal of Cleaner Production, 101, 278-291. https://doi.org/https://doi.org/10.1016/j.jclepro.2015.03.084

Pachauri, R. K., Allen, M. R., Barros, V. R., Broome, J., Gramer, W., Christ, R., Church, J. A., Clarke, L., Dahe, Q., \& Dasgupta, P. (2014). Climate Change 2014: Synthesis Report. Contribution of Working Groups I, II and III to the Fifth Assessment Report of the Intergovernmental Panel on Climate Change. I. P. o. C. Change.

https://www.ipcc.ch/site/assets/uploads/2018/05/SYR AR5 FINAL full wcover . $\mathrm{pdf}$

Pari, L., Suardi, A., Frąckowak, P., Adamczyk, F., Szaroleta, M., Santangelo, E., Bergonzoli, S., Del Giudice, A., \& Dyjakon, A. (2018, 2018/10/01/). Two innovative prototypes for collecting pruning biomass: Early performance tests and assessment of the work quality. Biomass and Bioenergy, 117, 96-101. https://doi.org/https://doi.org/10.1016/j.biombioe.2018.07.010

Pękala, Ł. M., Tan, R. R., Foo, D. C. Y., \& Jeżowski, J. M. (2010, 2010/06/01/). Optimal energy planning models with carbon footprint constraints. Applied Energy, 87(6), 1903-1910. https://doi.org/https://doi.org/10.1016/j.apenergy.2009.12.012

Peña, N. (2008). Biofuels for transportation: a climate perspective. P. C. o. G. C. C. Arlington. https://www.c2es.org/document/biofuels-for-transportation-a-climateperspective/

Pereira, C. L. F., \& Ortega, E. (2010, 2010/01/01/). Sustainability assessment of large-scale ethanol production from sugarcane. Journal of Cleaner Production, 18(1), 77-82. https://doi.org/https://doi.org/10.1016/j.jclepro.2009.09.007

Phyllis2. (2020). ECN Phyllis classification. ECN. https://phyllis.nl/Browse/Standard/ECNPhyllis

Piccolo, C., \& Bezzo, F. (2009, 2009/03/01/). A techno-economic comparison between two technologies for bioethanol production from lignocellulose. Biomass and Bioenergy, 33(3), 478-491. https://doi.org/https://doi.org/10.1016/j.biombioe.2008.08.008

Pimentel, D., Marklein, A., Toth, M. A., Karpoff, M. N., Paul, G. S., McCormack, R., Kyriazis, J., \& Krueger, T. (2009, January 29). Food Versus Biofuels: Environmental and Economic Costs [journal article]. Human Ecology, 37(1), 1. https://doi.org/http://doi.org/10.1007/s10745-009-9215-8

Pimentel, D., Patzek, T., \& Cecil, G. (2007). Ethanol production: energy, economic, and environmental losses. Reviews of environmental contamination and toxicology, 2541. 
Pimentel, D., \& Patzek, T. W. (2005, March 01). Ethanol Production Using Corn, Switchgrass, and Wood; Biodiesel Production Using Soybean and Sunflower [journal article]. Natural Resources Research, 14(1), 65-76. https://doi.org/http://doi.org/10.1007/s11053-005-4679-8

Piotrowski, S., Carus, M., \& Essel, R. (2015). Global bioeconomy in the conflict between biomass supply and demand. N. I. f. E. a. Innovation. http://biobased.eu/?did=29249\&vp edd act=show download

POET-DSM. (ND). EZ Bale Storage: Best Management Practices. Retrieved February 26 from http://poet-dsm.com/resources/docs/EZ-Bale-Storage-Guidelines.pdf

Portugal-Pereira, J., Soria, R., Rathmann, R., Schaeffer, R., \& Szklo, A. (2015, 2015/10/01/). Agricultural and agro-industrial residues-to-energy: Techno-economic and environmental assessment in Brazil. Biomass and Bioenergy, 81, 521-533. https://doi.org/https://doi.org/10.1016/j.biombioe.2015.08.010

Pradhan, A., Shrestha, D., McAloon, A., Yee, W., Haas, M., Duffield, J., \& Shapouri, H. (2009). Energy life-cycle assessment of soybean biodiesel (Agricultural Economic Report Number 845, Issue. U. S. D. o. Agriculture. https://www.usda.gov/oce/reports/energy/ELCAofSoybeanBiodiese191409.pdf

Rastogi, M., \& Shrivastava, S. (2017, 2017/12/01/). Recent advances in second generation bioethanol production: An insight to pretreatment, saccharification and fermentation processes. Renewable and Sustainable Energy Reviews, 80, 330-340. https://doi.org/https://doi.org/10.1016/j.rser.2017.05.225

Reddy, N., \& Yang, Y. (2005, 2005/01/01/). Biofibers from agricultural byproducts for industrial applications. Trends in Biotechnology, 23(1), 22-27. https://doi.org/https://doi.org/10.1016/j.tibtech.2004.11.002

Redin, M., Recous, S., Aita, C., Dietrich, G., Skolaude, A. C., Ludke, W. H., Schmatz, R., \& Giacomini, S. J. (2014, 2014/11/01/). How the chemical composition and heterogeneity of crop residue mixtures decomposing at the soil surface affects $C$ and N mineralization. Soil Biology and Biochemistry, 78, 65-75.

https://doi.org/https://doi.org/10.1016/j.soilbio.2014.07.014

Rees, W., \& Wackernagel, M. (1996, 1996/07/01). Urban ecological footprints: Why cities cannot be sustainable-And why they are a key to sustainability. Environmental Impact Assessment Review, 16(4), 223-248.

https://doi.org/http://dx.doi.org/10.1016/S0195-9255(96)00022-4

Reijnders, L., \& Huijbregts, M. A. J. (2008, 2008/12/01/). Biogenic greenhouse gas emissions linked to the life cycles of biodiesel derived from European rapeseed and Brazilian soybeans. Journal of Cleaner Production, 16(18), 1943-1948. https://doi.org/https://doi.org/10.1016/j.jclepro.2008.01.012

Rentizelas, A. A., Tolis, A. J., \& Tatsiopoulos, I. P. (2009, 2009/05/01/). Logistics issues of biomass: The storage problem and the multi-biomass supply chain. Renewable and Sustainable Energy Reviews, 13(4), 887-894.

https://doi.org/https://doi.org/10.1016/j.rser.2008.01.003

RFA. (2015). Fuel Ethanol Trade Measurements and Conversions. Renewable Fuels

Association. Retrieved March 18, 2019 from http://www.ethanolrfa.org/wpcontent/uploads/2015/12/Fuel-Ethanol-Trade-Measurements-andConversions RFA.pdf 
Rogner, H.-H., Aguilera, R. F., Archer, C., Bertani, R., Bhattacharya, S. C., Dusseault, M. B., Gagnon, L., Haberl, H., Hoogwijk, M., Johnson, A., Rogner, M. L., Wagner, H., \& Yakushev, V. (2012). Chapter 7 - Energy Resources and Potentials. In Global Energy Assessment - Toward a Sustainable Future (pp. 423-512). www.globalenergyassessment.org

Rose, S. K., Kriegler, E., Bibas, R., Calvin, K., Popp, A., van Vuuren, D. P., \& Weyant, J. (2014, April 01). Bioenergy in energy transformation and climate management [journal article]. Climatic Change, 123(3), 477-493. https://doi.org/10.1007/s10584$\underline{013-0965-3}$

Rulli, M. C., Bellomi, D., Cazzoli, A., De Carolis, G., \& D'Odorico, P. (2016, Mar 03). The water-land-food nexus of first-generation biofuels. Sci Rep, 6, 22521. https://doi.org/http://doi.org/10.1038/srep22521

Ryan, P., \& Openshaw, K. (1991). Assessment of Biomass Energy Resources: A Discussion on Its Need and Methodology. T. W. Bank.

http://documents.worldbank.org/curated/en/918181468765887106/pdf/multipage.pdf

Sadoff, C. W., Borgomeo, E., \& Uhlenbrook, S. (2020, 2020/05/01). Rethinking water for SDG 6. Nature Sustainability, 3(5), 346-347. https://doi.org/10.1038/s41893-020$\underline{0530-9}$

Saha, B. C., Nichols, N. N., Qureshi, N., Kennedy, G. J., Iten, L. B., \& Cotta, M. A. (2015, 2015/01/01/). Pilot scale conversion of wheat straw to ethanol via simultaneous saccharification and fermentation. Bioresource Technology, 175, 17-22. https://doi.org/https://doi.org/10.1016/j.biortech.2014.10.060

Salvi, B. L., \& Panwar, N. L. (2012, 2012/08/01/). Biodiesel resources and production technologies - A review. Renewable and Sustainable Energy Reviews, 16(6), 36803689. https://doi.org/https://doi.org/10.1016/j.rser.2012.03.050

Šarauskis, E., Buragienė, S., Masilionytė, L., Romaneckas, K., Avižienytė, D., \& Sakalauskas, A. (2014, 2014/05/01/). Energy balance, costs and CO2 analysis of tillage technologies in maize cultivation. Energy, 69(Supplement C), 227-235. https://doi.org/https://doi.org/10.1016/j.energy.2014.02.090

Scarlat, N., Blujdea, V., \& Dallemand, J.-F. (2011, 2011/05/01/). Assessment of the availability of agricultural and forest residues for bioenergy production in Romania. Biomass and Bioenergy, 35(5), 1995-2005. https://doi.org/https://doi.org/10.1016/j.biombioe.2011.01.057

Scarlat, N., Martinov, M., \& Dallemand, J.-F. (2010, 2010/10/01/). Assessment of the availability of agricultural crop residues in the European Union: Potential and limitations for bioenergy use. Waste Management, 30(10), 1889-1897. https://doi.org/https://doi.org/10.1016/j.wasman.2010.04.016

Schmer, M. R., Vogel, K. P., Mitchell, R. B., \& Perrin, R. K. (2008, January 15, 2008). Net energy of cellulosic ethanol from switchgrass. Proceedings of the National Academy of Sciences, 105(2), 464-469. https://doi.org/http://doi.org/10.1073/pnas.0704767105

Schyns, J. F., Booij, M. J., \& Hoekstra, A. Y. (2017, 2017/09/01/). The water footprint of wood for lumber, pulp, paper, fuel and firewood. Advances in Water Resources, 107, 490-501. https://doi.org/https://doi.org/10.1016/j.advwatres.2017.05.013 
Searchinger, T. D., Beringer, T., Holtsmark, B., Kammen, D. M., Lambin, E. F., Lucht, W., Raven, P., \& van Ypersele, J.-P. (2018, 2018/09/12). Europe's renewable energy directive poised to harm global forests. Nature Communications, 9(1), 3741. https://doi.org/10.1038/s41467-018-06175-4

Searle, S., \& Malins, C. (2015). A reassessment of global bioenergy potential in 2050. GCB Bioenergy, 7(2), 328-336. https://doi.org/10.1111/gcbb.12141

Searle, S. Y., \& Malins, C. J. (2016, 2016/06/01/). Waste and residue availability for advanced biofuel production in EU Member States. Biomass and Bioenergy, 89, 210. https://doi.org/https://doi.org/10.1016/j.biombioe.2016.01.008

Shyam, M. (2002, 2002/06/01/). Agro-residue-based renewable energy technologies for rural development. Energy for Sustainable Development, 6(2), 37-42. https://doi.org/https://doi.org/10.1016/S0973-0826(08)60311-7

Simpson, G. B., \& Jewitt, G. P. W. (2019, 2019-February-08). The Development of the Water-Energy-Food Nexus as a Framework for Achieving Resource Security: A Review [Review]. Frontiers in Environmental Science, 7(8). https://doi.org/10.3389/fenvs.2019.00008

Sims, R., Taylor, M., Saddler, J., and Mabee, W. (2008). From 1st - to 2nd - Generation Biofuel Technologies: An overview of current industry and RDED activities. I. E. Agency.

Sims, R. E. H., Mabee, W., Saddler, J. N., \& Taylor, M. (2010, 2010/03/01/). An overview of second generation biofuel technologies. Bioresource Technology, 101(6), 15701580. https://doi.org/https://doi.org/10.1016/j.biortech.2009.11.046

Sinclair, T. R., \& Rufty, T. W. (2012, 2012/12/01/). Nitrogen and water resources commonly limit crop yield increases, not necessarily plant genetics. Global Food Security, 1(2), 94-98. https://doi.org/https://doi.org/10.1016/j.gfs.2012.07.001

Sluiter, J. B., Ruiz, R. O., Scarlata, C. J., Sluiter, A. D., \& Templeton, D. W. (2010, 2010/08/25). Compositional Analysis of Lignocellulosic Feedstocks. 1. Review and Description of Methods. Journal of Agricultural and Food Chemistry, 58(16), 9043-9053. https://doi.org/10.1021/jf1008023

Smith, E. G., Janzen, H., \& Newlands, N. K. (2007). Energy balances of biodiesel production from soybean and canola in Canada. Canadian journal of plant science, 87(4), 793-801.

Sosa, A., Acuna, M., McDonnell, K., \& Devlin, G. (2015, 2015/01/01/). Controlling moisture content and truck configurations to model and optimise biomass supply chain logistics in Ireland. Applied Energy, 137, 338-351. https://doi.org/https://doi.org/10.1016/j.apenergy.2014.10.018

Sovacool, B. K. (2016, 2016/03/01/). How long will it take? Conceptualizing the temporal dynamics of energy transitions. Energy Research \& Social Science, 13, 202-215. https://doi.org/https://doi.org/10.1016/j.erss.2015.12.020

Spinelli, R., Magagnotti, N., \& Nati, C. (2010, 2010/03/01/). Harvesting vineyard pruning residues for energy use. Biosystems Engineering, 105(3), 316-322. https://doi.org/https://doi.org/10.1016/j.biosystemseng.2009.11.011

Spinelli, R., Nati, C., Pari, L., Mescalchin, E., \& Magagnotti, N. (2012, 2012/01/01/). Production and quality of biomass fuels from mechanized collection and processing of vineyard pruning residues. Applied Energy, 89(1), 374-379. https://doi.org/https://doi.org/10.1016/j.apenergy.2011.07.049 
Spöttle M., A., A., Toop, G., Peters, D., Gamba, L., Ping, S., van Steen, H., and Bellefleur, D. (2013). Low ILUC potential of wastes and residues for biofuels: Straw, forestry residues, UCO, corn cobs. ECOFYS.

https://library.wur.nl/WebQuery/titel/2043714

Steen-Olsen, K., Weinzettel, J., Cranston, G., Ercin, A. E., \& Hertwich, E. G. (2012, 2012/10/16). Carbon, Land, and Water Footprint Accounts for the European Union: Consumption, Production, and Displacements through International Trade. Environmental Science \& Technology, 46(20), 10883-10891.

https://doi.org/http://doi.org/10.1021/es301949t

Stephenson, A. L., Dennis, J. S., \& Scott, S. A. (2008, 2008/11/01/). Improving the sustainability of the production of biodiesel from oilseed rape in the UK. Process Safety and Environmental Protection, 86(6), 427-440. https://doi.org/https://doi.org/10.1016/j.psep.2008.06.005

Su, M. H., Huang, C. H., Li, W. Y., Tso, C. T., \& Lur, H. S. (2015, 2015/02/01/). Water footprint analysis of bioethanol energy crops in Taiwan. Journal of Cleaner Production, 88, 132-138. https://doi.org/http://dx.doi.org/10.1016/j.jclepro.2014.06.020

TARA. (Nd). Biomass Estimation and Methodology: Village Electrification through Sustainable use of Renewable Energy (VE-SuRE). E. o. S. i. India.

https://www.eda.admin.ch/dam/countries/countriescontent/india/en/resource en 224455.pdf

Terrapon-Pfaff, J. C. (2012). Linking Energy- and Land-Use Systems: Energy Potentials and Environmental Risks of Using Agricultural Residues in Tanzania. Sustainability, 4(3), 278-293. https://www.mdpi.com/2071-1050/4/3/278

Thamsiriroj, T., \& Murphy, J. D. (2009, 2009/05/01/). Is it better to import palm oil from Thailand to produce biodiesel in Ireland than to produce biodiesel from indigenous Irish rape seed? Applied Energy, 86(5), 595-604.

https://doi.org/https://doi.org/10.1016/j.apenergy.2008.07.010

The World Bank. (2020). Getting electricity: Price of electricity (US cents per kWh) (DB16-20 Methodology). T. W. Bank.

https://databank.worldbank.org/reports.aspx?source=3001\&series=IC.ELC.PRI. KH.DB1619\#

Trainor, A. M., McDonald, R. I., \& Fargione, J. (2016). Energy Sprawl Is the Largest Driver of Land Use Change in United States. PLOS ONE, 11(9), e0162269. https://doi.org/10.1371/journal.pone.0162269

Transport \& Environment. (2018). Roadmap to decarbonising European cars. T. Environment. https://www.transportenvironment.org/sites/te/files/publications/2050_strategy cars FINAL.pdf

Tubiello, F., Cóndor-Golec, R., Salvatore, M., Piersante, A., Federici, S., Ferrara, A., Rossi, S., Flammini, A., Cardenas, P., \& Biancalani, R. (2015). Estimating greenhouse gas emissions in agriculture: a manual to address data requirements for developing countries. Estimating greenhouse gas emissions in agriculture: a manual to address data requirements for developing countries.

Turner, J. A. (1999, Jul 30). A realizable renewable energy future. Science, 285(5428), 687689. https://doi.org/http://doi.org/10.1126/science.285.5428.687 
Unal, H., \& Alibas, K. (2007, 2007/04/30). Agricultural Residues as Biomass Energy. Energy Sources, Part B: Economics, Planning, and Policy, 2(2), 123-140.

https://doi.org/10.1080/15567240600629401

UNCTAD. (2015). Second Generation Biofuel Markets: State of play, trade and developing country perspectives U. N. C. o. T. a. Development. http://unctad.org/en/PublicationsLibrary/ditcted2015d8 en.pdf

USDA. (2017). 2016 Agricultural Chemical Use Survey: Corn. U. S. D. o. Agriculture. https://www.nass.usda.gov/Surveys/Guide to NASS Surveys/Chemical Use/2 016 Corn Potatoes/ChemUseHighlights Corn 2016.pdf

USDOE. (2009). Energy requirements for hydrogen gas compression and liquefaction as related to vehicle storage needs (9013). U. S. D. o. Energy.

https://www.hydrogen.energy.gov/pdfs/9013 energy requirements for hydro gen gas compression.pdf

USDOE. (2014). Alternative Fuels Data Center - Fuel Properties Comparison. US Department of Energy. Retrieved June 27, 2019 from https://afdc.energy.gov/fuels/fuel comparison chart.pdf

USDOE. (2019a). Compare Fuel Cell Vehicles. United States Department of Energy. Retrieved May 28 from https://www.fueleconomy.gov/feg/fcv sbs.shtml

USDOE. (2019b). Compare Side-by-Side. United States Department of Energy. Retrieved July 1 from https://www.fueleconomy.gov/feg/Find.do?action=sbsSelect

USDOE. (2019c). Find-a-Car Help. U.S. Department of Energy, Office of Energy Efficiency \& Renewable Energy. Retrieved May 21 from https://www.fueleconomy.gov/feg/findacarhelp.shtml\#epaSizeClass

USEIA. (2019). International Energy Outlook 2019: with projections to 2050. U. S. E. I. Administration. https://www.eia.gov/outlooks/ieo/pdf/ieo2019.pdf

USEPA. (2016). Greenhouse Gas Inventory Guidance: Direct Emissions from Mobile Combustion Sources. U. S. E. P. Agency. https://www.epa.gov/sites/production/files/201603/documents/mobileemissions 3 2016.pdf

van Duren, I., Voinov, A., Arodudu, O., \& Firrisa, M. T. (2015, 2015/02/01/). Where to produce rapeseed biodiesel and why? Mapping European rapeseed energy efficiency. Renewable Energy, 74, 49-59.

https://doi.org/https://doi.org/10.1016/j.renene.2014.07.016

Vanham, D., Leip, A., Galli, A., Kastner, T., Bruckner, M., Uwizeye, A., van Dijk, K., Ercin, E., Dalin, C., Brandão, M., Bastianoni, S., Fang, K., Leach, A., Chapagain, A., Van der Velde, M., Sala, S., Pant, R., Mancini, L., Monforti-Ferrario, F., Carmona-Garcia, G., Marques, A., Weiss, F., \& Hoekstra, A. Y. (2019, 2019/11/25/). Environmental footprint family to address local to planetary sustainability and deliver on the SDGs. Science of The Total Environment, 693, 133642. https://doi.org/https://doi.org/10.1016/j.scitotenv.2019.133642

Vanham, D., Medarac, H., Schyns, J., Hogeboom, R., \& Magagna, D. (2019, 2019/10/15). The consumptive water footprint of the European Union energy sector. Environmental Research Letters, 14(10), 104016. https://doi.org/10.1088/17489326/ab374a 
Vassilev, S. V., Baxter, D., Andersen, L. K., \& Vassileva, C. G. (2010, 2010/05/01/). An overview of the chemical composition of biomass. Fuel, 89(5), 913-933. https://doi.org/https://doi.org/10.1016/j.fuel.2009.10.022

Velázquez-Martí, B., Fernández-González, E., López-Cortés, I., \& Salazar-Hernández, D. M. (2011, 2011/07/01/). Quantification of the residual biomass obtained from pruning of trees in Mediterranean olive groves. Biomass and Bioenergy, 35(7), 3208-3217. https://doi.org/https://doi.org/10.1016/j.biombioe.2011.04.042

Velázquez Martí, B., Fernández González, E., López Cortés, I., \& Callejón-Ferre, A. (2013). Prediction and evaluation of biomass obtained from citrus trees pruning. Journal of Food Agriculture and Environment, 11(3\&4), 1485-1494.

Vohra, M., Manwar, J., Manmode, R., Padgilwar, S., \& Patil, S. (2014, 2014/03/01/). Bioethanol production: Feedstock and current technologies. Journal of Environmental Chemical Engineering, 2(1), 573-584. https://doi.org/https://doi.org/10.1016/j.jece.2013.10.013

von Blottnitz, H., \& Curran, M. A. (2007, //). A review of assessments conducted on bioethanol as a transportation fuel from a net energy, greenhouse gas, and environmental life cycle perspective. Journal of Cleaner Production, 15(7), 607-619. https://doi.org/http://doi.org/10.1016/j.jclepro.2006.03.002

Wageningen University. (2013). Rice straw and Wheat straw: Potential feedstocks for the Biobased Economy. N. A. M. o. E. Affairs. https://library.wur.nl/WebQuery/wurpubs/fulltext/288866

Wang, M., Han, J., Dunn, J. B., Cai, H., \& Elgowainy, A. (2012). Well-to-wheels energy use and greenhouse gas emissions of ethanol from corn, sugarcane and cellulosic biomass for US use. Environmental Research Letters, 7(4), 045905.

Warner, E., Schwab, A., \& Bacovsky, D. (2016). 2016 Survey for Non-Startch Alcohol and Renewable Hydrocarbon Biofuels Producers. N. R. E. Laboratory \& B. 2020+. https://afdc.energy.gov/files/u/publication/2016 survey nonstarch alcohol renewable hydrocarbon biofuels producers.pdf

WB. (2017). Energy use (kg of oil equivalent per capita): World. World Bank. Retrieved July 27, 2017 from http://data.worldbank.org/indicator/EG.USE.PCAP.KG.OE

Weinzettel, J., Hertwich, E. G., Peters, G. P., Steen-Olsen, K., \& Galli, A. (2013, 4//). Affluence drives the global displacement of land use. Global Environmental Change, 23(2), 433-438. https://doi.org/http://dx.doi.org/10.1016/j.gloenvcha.2012.12.010

Wiedmann, T., \& Minx, J. (2008). A definition of 'carbon footprint'. Ecological economics research trends, 1, 1-11.

Wilhelm, W., Johnson, J. M., Hatfield, J., Voorhees, W., \& Linden, D. (2004). Crop and soil productivity response to corn residue removal. Agronomy Journal, 96(1), 117.

Williams, E. D., \& Simmons, J. E. (2013). Water in the energy industry: An introduction. B. Petroleum. https://www.bp.com/content/dam/bp/pdf/sustainability/groupreports/BP-ESC-water-handbook.pdf

Wuester, H., Ferroukhi, R., El-Katiri, L., Saygin, D., Rinke, T., \& Nagpal, D. (2015). Rethinking Energy: Renewable Energy and Climate Change. I. R. E. Agency. https://www.irena.org/-/media/Files/IRENA/Agency/Publication/2015/IRENAREthinking_Energy 2nd report_2015.pdf 
WWAP. (2014). The United Nations World Water Development Report 2014: Water and Energy (World Water Development Report, Issue. UNESCO.

http://www.unesco.org/new/en/naturalsciences/environment/water/wwap/wwdr/2014-water-and-energy/

Yang, H., Zhou, Y., \& Liu, J. G. (2009, May). Land and water requirements of biofuel and implications for food supply and the environment in China. Energy Policy, 37(5), 1876-1885. https://doi.org/http://doi.org/10.1016/j.enpol.2009.01.035

Yee, K. F., Tan, K. T., Abdullah, A. Z., \& Lee, K. T. (2009, 2009/11/01/). Life cycle assessment of palm biodiesel: Revealing facts and benefits for sustainability. Applied Energy, 86, S189-S196. https://doi.org/https://doi.org/10.1016/j.apenergy.2009.04.014

Zabed, H., Sahu, J. N., Suely, A., Boyce, A. N., \& Faruq, G. (2017, 2017/05/01/). Bioethanol production from renewable sources: Current perspectives and technological progress. Renewable and Sustainable Energy Reviews, 71(Supplement C), 475-501. https://doi.org/https://doi.org/10.1016/j.rser.2016.12.076

Zafar, S. (2018). A Primer on Agricultural Residues. BioEnergy Consult. Retrieved March 19, 2019 from https://www.bioenergyconsult.com/agricultural-residues/

Zhang, J., \& Xu, L. (2015, 6/1/). Embodied carbon budget accounting system for calculating carbon footprint of large hydropower project. Journal of Cleaner Production, 96, 444-451. https://doi.org/http://dx.doi.org/10.1016/j.jclepro.2013.10.060

Zhang, S., Maréchal, F., Gassner, M., Périn-Levasseur, Z., Qi, W., Ren, Z., Yan, Y., \& Favrat, D. (2009, 2009/03/19). Process Modeling and Integration of Fuel Ethanol Production from Lignocellulosic Biomass Based on Double Acid Hydrolysis. Energy \& Fuels, 23(3), 1759-1765. https://doi.org/10.1021/ef801027x

Zhao, X., Ke, Y., Zuo, J., Xiong, W., \& Wu, P. (2020, 2020/05/20/). Evaluation of sustainable transport research in 2000-2019. Journal of Cleaner Production, 256, 120404. https://doi.org/https://doi.org/10.1016/j.jclepro.2020.120404

Zijlema, P. J. (2018). The Netherlands: list of fuels and standard $\mathrm{CO}_{2}$ emission factors version of January 2018. N. E. Agency. https://english.rvo.nl/sites/default/files/2017/04/The Netherlands list of fuels version January 2017 final.pdf

Zoghlami, A., \& Paës, G. (2019, 2019-December-18). Lignocellulosic Biomass: Understanding Recalcitrance and Predicting Hydrolysis [Mini Review]. Frontiers in Chemistry, 7(874). https://doi.org/10.3389/fchem.2019.00874

ZSW. (2019). Global E-car Count Up from 3.4 to 5.6 Million. https://www.zswbw.de/fileadmin/user_upload/PDFs/Pressemitteilungen/2019/pr02-2019-ZSWWorldwideNumbersElectriccars.pdf

Züttel, A., Remhof, A., Borgschulte, A., \& Friedrichs, O. (2010, 2010/07/28). Hydrogen: the future energy carrier. Philosophical Transactions of the Royal Society A: Mathematical, Physical and Engineering Sciences, 368(1923), 3329-3342. https://doi.org/10.1098/rsta.2010.0113 


\section{Appendix A: An Appendix to Chapter 2}

\section{Supporting Information}

The selected system boundaries for input energy calculations are consistent with the previous LCA studies on biofuels (Stephenson et al., 2008; Thamsiriroj \& Murphy, 2009) and are logically modified for the bioelectricity route. Also consistent with previous studies (Schmer et al., 2008; Thamsiriroj \& Murphy, 2009), the common functional unit utilized in this paper for energy balance analysis of biofuels is GJ ha-1. This choice is the most logical in this study that serves as a reference to normalize inputs and outputs that is the main purpose of the functional unit (Cherubini et al., 2009).

Quantity of input energy in various stages of bioenergy production do not differ between scenarios. The quality of input energy, however, differs between the two scenarios based on the scenario assumptions that then affects the production efficiency of the feedback loop. For ease of presentation, the gross bioenergy calculation steps are divided into three parts. Part I is alike for both scenarios and describes methods and data for calculating the quantity of input energy per stage of bioenergy production. Part II describes partitioning of input energy into electricity and fuel which differ between the two scenarios. Part III describes the final gross bioenergy calculation using the feedback loop that depends on values from part II.

\section{Part I - input energy calculations}

Input energy for bioelectricity and biofuel production are similar during the agriculture stage but differ in the production stage (Fig. S1). Bioelectricity can be generated through (a) bioelectricity only and (b) combined heat and power (CHP) routes. Biofuels are divided into bioethanol distilled from maize, sugar beet, and sugarcane, and biodiesel produced from soybean and rapeseed. 


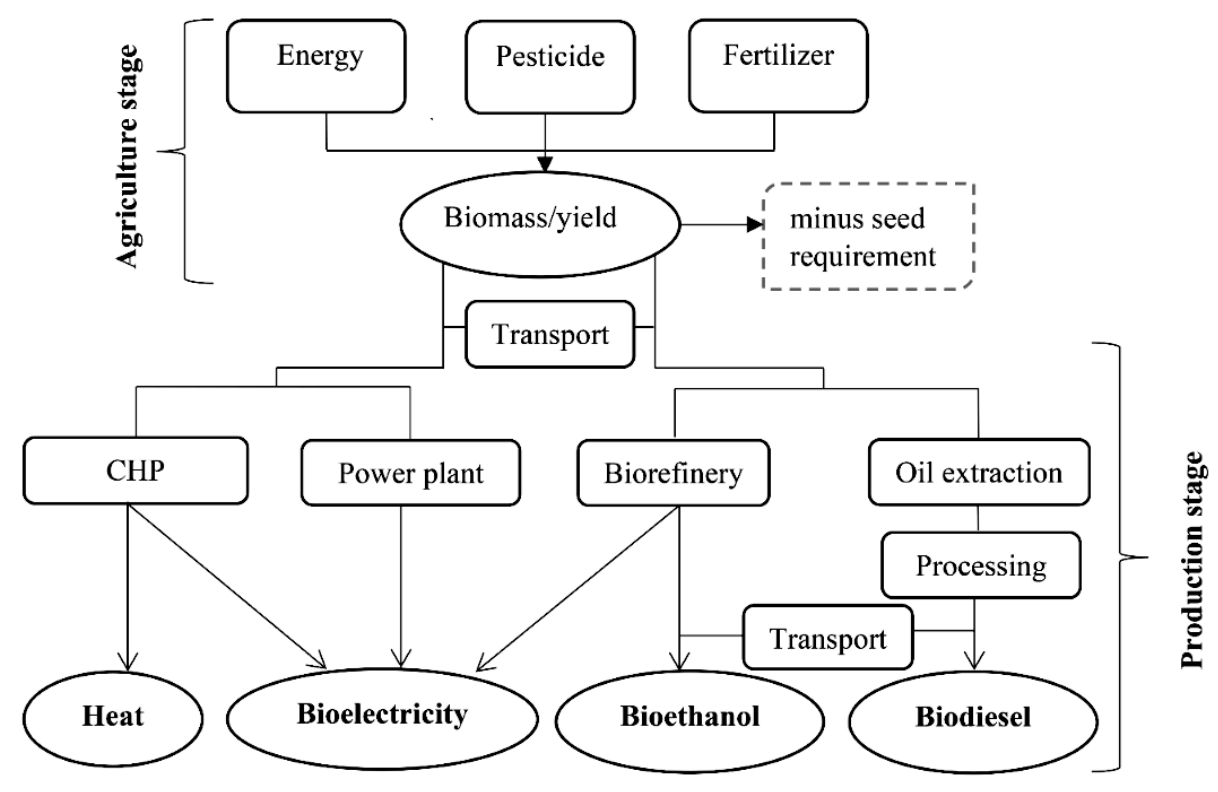

Fig. A1. Simplified representation of the bioenergy production system. Biorefinery using sugarcane as feedstock can co-produce bioelectricity from bagasse.

Selected crops have different seed, pesticide, and fertilizer application rates per cultivation area (Table A1). Consistent with the study of Ahlgren et al. (2011), seed inputs (Table A2) are ignored after subtracting equivalent amounts from the crops' economic yields. In the bioelectricity and CHP routes, the crop's economic yields are converted to total biomass yields using the harvest index (HI) of specific crops (Table A10). The pesticide category is divided into insecticides and herbicides. The fertilizer category is divided into nitrogen, phosphate and potash. Energy consumed by machinery for six types of field activities are assumed to be similar for all crops with a small adjustment for sugarcane (see note under Table A1). Six types of field activities are (1) stubble cultivation, (2) shallow ploughing, (3) pre-sowing cultivation, (4) conventional drilling, (5) pesticide spraying, and (6) harvesting. 
Table A1. Overview of energy requirements in the agricultural production.

\begin{tabular}{|c|c|c|c|c|c|c|}
\hline Input & Category & Requirement & Reference & \multicolumn{2}{|c|}{ Energy equivalent } & Notes \\
\hline & & $\mathrm{L} \mathrm{ha}^{-1}$ & & $\mathrm{MJ} \mathrm{L}^{-1}$ & MJ ha-1 & \\
\hline \multirow{8}{*}{$\begin{array}{c}\text { Ag. } \\
\text { machinery* }\end{array}$} & $\begin{array}{c}\text { Stubble } \\
\text { cultivation }\end{array}$ & 10.7 & \multirow{7}{*}{$\begin{array}{c}\text { Šarauskis et } \\
\text { al. (2014) }\end{array}$} & \multirow{7}{*}{35.9} & 384 & \multirow{7}{*}{$\begin{array}{c}\text { Assuming a } \\
\text { caloric value of } \\
42.6 \mathrm{MJ} \mathrm{kg}^{-1} \text { for } \\
\text { diesel (IEA, } \\
\text { 2015a) and diesel } \\
\text { density of } 0.8424 \\
\text { g per cm } \\
\text { (Alptekin \& } \\
\text { Canakci, 2008) }\end{array}$} \\
\hline & $\begin{array}{l}\text { Shallow } \\
\text { ploughing }\end{array}$ & 16.5 & & & 592 & \\
\hline & $\begin{array}{l}\text { Pre-sowing } \\
\text { cultivation }\end{array}$ & 4.6 & & & 165 & \\
\hline & $\begin{array}{c}\text { Conventional } \\
\text { drilling }\end{array}$ & 2.3 & & & 83 & \\
\hline & $\begin{array}{l}\text { Pesticide } \\
\text { spraying }\end{array}$ & 0.9 & & & 32 & \\
\hline & Harvesting & 23.2 & & & 833 & \\
\hline & Total & 58.2 & & & 2089 & \\
\hline & & $\mathrm{kg} \mathrm{ha}^{-1}$ & & MJ kg-1 & & \\
\hline \multirow{4}{*}{ Fertilizer $^{\mathrm{a}}$} & Nitrogen & \multirow{3}{*}{ Varies by crop } & \multirow{3}{*}{ Table A3 } & 78.2 & \multirow{3}{*}{ Table A3 } & Original \\
\hline & Phosphate & & & 17.5 & & energy values \\
\hline & Potash & & & 13.8 & & $\begin{array}{c}\text { and Parmenter } \\
\text { (2004) }\end{array}$ \\
\hline & & $\mathrm{kg} \mathrm{ha}^{-1}$ & & MJ kg-1 & & \\
\hline \multirow{3}{*}{ Pesticide } & Insecticide & \multirow{2}{*}{ Varies by crop } & \multirow{2}{*}{ Table A4 } & 127.9 & \multirow{2}{*}{ Table A4 } & Total process \\
\hline & Herbicide & & & 146.7 & & $\begin{array}{c}\text { Audsley et al. } \\
\text { (2009) }\end{array}$ \\
\hline & & $\mathrm{km}$ & & MJ t $\mathrm{t}^{-1} \mathrm{~km}^{-1}$ & & \\
\hline \multirow{2}{*}{ Transport } & $\begin{array}{c}\text { Crop/biomass } \\
\text { processing }\end{array}$ & 50 & \multirow{2}{*}{ Assumption } & \multirow{2}{*}{3} & \multirow{2}{*}{ Table A5 } & \multirow{2}{*}{$\begin{array}{c}\text { Energy intensity } \\
\text { of truck } \\
\text { transport from } \\
\text { EEA (2016) }\end{array}$} \\
\hline & Fuel delivery & 50 & & & & \\
\hline
\end{tabular}

Notes: * For sugarcane, the diesel requirements for each category is divided by six because it is sowed every six years except for 'pesticide spraying' and 'harvesting' categories that are performed annually. a Original values that still include the non-energy use of fossil fuels in fertilizer production. 
Table A2. Seed requirements $\left(\mathrm{kg} \mathrm{ha}^{-1}\right)$.

\begin{tabular}{|c|c|l|}
\hline Crop & Seed requirement & \multicolumn{1}{|c|}{ Reference } \\
\hline Maize & 21.0 & Pimentel et al. (2007) \\
\hline Sugar beet & 1.4 & Auburger et al. (2016) \\
\hline Sugarcane* & 2,000 & Boddey et al. (2008) \\
\hline Rapeseed & 12.4 & CCC (2017) \\
\hline Soybean & 76.1 & Pradhan et al. (2009) \\
\hline
\end{tabular}

Note: *Sugarcane is grown from setts. Requirement is $12,000 \mathrm{~kg} \mathrm{ha}^{-1}$ sowed every 6 years.

The fertilizer application rates vary widely between crops. In this study, fertilizer application rates correspond to rates applied in major bioenergy producing countries. The average fertilizer application rate in 2016 for maize is obtained from the USDA (2017). ${ }^{3}$ The fertilizer application rate for sugar beet is obtained from Biograce (2015). For sugarcane, the average fertilizer application rate calculated using data for five regions of Brazil is obtained from FAO (2004). Fertilizer application rates for soybean and rapeseed cultivation are model estimates from Fore et al. (2011).

Energy requirements for producing fertilizer are provided per stage and unit of nitrogen, phosphate, and potash production in Gellings and Parmenter (2004). The four specific steps of the fertilizer production are: (1) production, (2) packaging, (3) transport and (4) application. Importantly, energy requirements for nitrogen fertilizer production include fossil fuels used as non-energy feedstock, i.e. natural gas as hydrogen source in the ammonia production (EC, 2007; Fertilizers Europe, 2000). Natural gas requirement for the fertilizer production can be in the range of $80 \%$ (Gellings \& Parmenter, 2004) and consistent with the production process, the methane input is assumed a non-energy use as a source of hydrogen. Similarly production of plastic packaging for all fertilizers in step (2) is fossil-fuel intensive that is assumed as $80 \%$ non-energy use. Table S3 presents fertilizer requirements and their energy equivalents using global average energy requirements from Gellings and Parmenter (2004) after adjusting for non-energy uses.

Table A3. Fertilizer application rates and their corresponding energy values.

\begin{tabular}{|c|c|c|c|c|c|c|c|c|}
\hline \multirow{2}{*}{ Crop } & \multicolumn{3}{|c|}{ Requirement $\mathbf{( k g ~ h a}^{-1} \mathbf{~}$} & \multirow{2}{*}{ Reference } & \multicolumn{3}{|c|}{ Energy equivalent (GJ ha-1) } \\
\cline { 2 - 5 } \cline { 7 - 9 } & $\mathrm{N}$ & $\mathrm{P}$ & $\mathrm{K}$ & & $\mathrm{N}$ & $\mathrm{P}$ & $\mathrm{K}$ & Total \\
\hline Maize & 162.5 & 68.4 & 89.7 & USDA (2017) & 3.3 & 1.1 & 1.1 & 5.5 \\
\hline Sugar beet & 119.7 & 59.7 & 134.9 & Biograce (2015) & 2.5 & 0.9 & 1.7 & 5.0 \\
\hline Sugarcane & 47.8 & 44 & 100.6 & FAO (2004) & 1.0 & 0.7 & 1.2 & 2.9 \\
\hline Soybean & 4.9 & 16 & 26.8 & Fore et al. & 0.1 & 0.2 & 0.3 & 0.7 \\
\hline Rapeseed & 100.9 & 28 & 33.6 & $(2011)$ & 2.1 & 0.4 & 0.4 & 2.9 \\
\hline
\end{tabular}

Insecticide and herbicide application rates also vary considerably across crops (Table A4). Insecticide and herbicide application rates for maize and soybean are calculated using the long-term average application rates in $\mathrm{lb}_{\text {acre }}{ }^{-1}$ (1998-2008) from Fernandez-Cornejo et al.

\footnotetext{
${ }^{3}$ Units reported in $\mathrm{lb} / \mathrm{ac}$ are converted to $\mathrm{kg} / \mathrm{ha}$ assuming $0.4536 \mathrm{~kg}$ per $\mathrm{lb}$ and 2.4711 acres per ha. 108
} 
(2014) and converted to $\mathrm{kg} \mathrm{ha}^{-1}$. For sugar beet cultivation, the insecticide application rate is obtained from Biograce (2015) and since no herbicide application data is provided, it is assumed zero. Insecticide and herbicide application for sugarcane are obtained from Macedo et al. (2008). Insecticide and herbicide application rates for rapeseed are obtained from Cai et al. (2015) and correspond to average application rates across 8 Canadian reconciliation units (the reconciliation units are defined as geographic regions that subdivide provinces according to the ecological conditions) in 2011. Average process energy requirements for insecticide and herbicide production are obtained from Audsley et al. (2009).

Table A4. Pesticide and herbicide application rates and embedded energy inputs.

\begin{tabular}{|c|c|c|c|c|c|c|}
\hline \multirow{2}{*}{ Crop } & \multicolumn{2}{|c|}{$\begin{array}{c}\text { Requirement (kg } \\
\left.\text { ha-1) }^{-1}\right)\end{array}$} & \multirow{2}{*}{ Reference } & \multicolumn{2}{|c|}{$\begin{array}{l}\text { Energy equivalent } \\
\qquad\left(\mathrm{GJ} \mathrm{ha}^{-1}\right)\end{array}$} & \multirow{2}{*}{$\begin{array}{c}\text { Tot } \\
\text { al }\end{array}$} \\
\hline & $\begin{array}{l}\text { Insectic } \\
\text { ide }\end{array}$ & $\begin{array}{c}\text { Herbic } \\
\text { ide }\end{array}$ & & $\begin{array}{l}\text { Insectic } \\
\text { ide }\end{array}$ & Herbicide & \\
\hline Maize & 0.12 & 2.42 & $\begin{array}{c}\text { Fernandez-Cornejo et } \\
\text { al. (2014) }\end{array}$ & 0.02 & 0.36 & 0.37 \\
\hline $\begin{array}{c}\text { Sugar } \\
\text { beet }\end{array}$ & 1.3 & 0 & Biograce (2015) & 0.17 & 0 & 0.17 \\
\hline $\begin{array}{l}\text { Sugarc } \\
\text { ane }\end{array}$ & 0.16 & 2.2 & Macedo et al. (2008) & 0.02 & 0.32 & 0.34 \\
\hline $\begin{array}{c}\text { Soybea } \\
\mathrm{n}\end{array}$ & 0.02 & 1.35 & $\begin{array}{c}\text { Fernandez-Cornejo et } \\
\text { al. (2014) }\end{array}$ & 0 & 0.18 & 0.18 \\
\hline $\begin{array}{c}\text { Rapese } \\
\text { ed }\end{array}$ & 0.09 & 0.6 & Cai et al. (2015) & 0.01 & 0.09 & 0.10 \\
\hline
\end{tabular}

Process energy calculation - bioelectricity

Bioelectricity generation involves transporting biomass from field to the power plant for combustion. The distance from fields to power plants is assumed $50 \mathrm{~km}$. The energy requirement for pre-processing biomass transport is calculated by multiplying distance by the amount of biomass yield per ha and energy intensity of truck transport per ton obtained from the EEA (2016). Energy inputs for biomass transport are presented in Table A5.

Table A5. Energy inputs for feedstock transport and biofuel delivery (GJ ha-1).

\begin{tabular}{|c|c|c|c|c|}
\hline \multirow{2}{*}{ Crop } & \multicolumn{2}{|c|}{ Pre-processing } & \multicolumn{2}{c|}{ Post-processing (biofuels) } \\
\cline { 2 - 5 } & Biofuel & Bioelectricity & Bioethanol & Biodiesel \\
\hline Maize & 0.84 & 1.87 & 0.28 & -- \\
\hline Sugar beet & 9.05 & 13.71 & 0.79 & -- \\
\hline Sugarcane & 10.12 & 17.07 & 0.79 & -- \\
\hline Soybean & 0.38 & 0.97 & -- & 0.06 \\
\hline Rapeseed & 0.30 & 0.96 & -- & 0.09 \\
\hline
\end{tabular}

Process energy calculation - biofuels 
Biofuel production steps are more extensive compared to bioelectricity production. First, energy is required to transport crops to biofuel factories for pre-processing. Second, energy is required to convert crops to biofuel at the factory. Third, energy is required to deliver biofuels to consumers. Transport distance of $50 \mathrm{~km}$ is assumed from fields to processing factory. Energy inputs for crop transport (pre-processing) are calculated similar to biomass transport (except only the economic yield is transported) and presented in Table A5.

Energy requirement to convert crops to biofuels differs depending on two key factors: the type of output (bioethanol versus biodiesel) and the feedstock. Maize processing into bioethanol, for example, is more energy intensive than sugarcane or sugar beet processing because starch has to be converted to sugar. In this study the mean energy requirement for producing bioethanol from maize and producing bioethanol from sugarcane are obtained from Wang et al. (2012). Energy requirement for producing bioethanol from sugar beet is assumed same as for producing bioethanol from sugarcane (Table A6). Energy requirement for producing a liter of bioethanol was converted to energy requirement per hectare using information on the density of bioethanol (Table 2.4), energy per unit weight of bioethanol assumed in this study and the gross bioethanol yield per hectare (Table 2.6).

Table A6. Energy inputs for biofuel processing (GJ ha'-1).

\begin{tabular}{|c|c|cc|c|}
\hline \multirow{2}{*}{ Crop } & Bioethanol production* & \multicolumn{2}{|c|}{ Biodiesel production } & T \\
& Biorefinery & Oil extraction & Processing & Total \\
\hline Maize & 17.95 & -- & -- & 17.95 \\
Sugar beet & 0.56 & -- & -- & 0.56 \\
Sugarcane & $0.56^{* *}$ & -- & -- & 0 \\
Soybean & -- & 3.61 & 2.32 & 5.94 \\
Rapeseed & -- & 2.09 & 2.86 & 4.95 \\
\hline
\end{tabular}

Notes: * Energy embedded in yeast and enzyme are not included. ${ }^{* *}$ For the reference only. Biorefinery energy input for sugarcane processing can be offset by burning bagasse (Macedo et al., 2008; Peña, 2008) and is subtracted later from the overall input energy calculation.

Biodiesel production steps can be grouped into two categories: oil extraction and processing. Oil extraction requires energy input for crushing, transfer, process heat, and conditioning that are obtained from Fore et al. (2011) for soybean and rapeseed (canola is treated as rapeseed). Processing requires energy for process heat, agitation, methanol, catalyst, and washing/drying that are also obtained from Fore et al. (2011). Energy requirements for biodiesel production are presented in Table A6.

Produced biofuels require additional energy as transport related energy to reach consumers. Thus, additional $50 \mathrm{~km}$ is assumed for biofuel deliveries. For biofuel delivery, gross bioethanol and biodiesel energy outputs per hectare (Table 2.6) are first converted to tons of biofuel yield per hectare using biofuel densities from Table 2.4 and then to GJ 
ha $^{-1}$ using the distance and energy intensity of truck transport (Table A1). Energy requirements for biofuel delivery (post-processing) is presented in Table A5.

\section{Part 2 - input energy quality}

Quality of energy inputs, i.e. electricity and liquid fuel inputs vary between the two scenarios due to the scenario assumptions. Specifically, a $100 \%$ scenario is electricity intensive, meaning that only energy inputs for aviation, maritime and freight transport are assumed as liquid fuel and all the remaining energy inputs are treated as electricity inputs. In contrast, all transport energy needs in a SDS-bio scenario are assumed as liquid fuel that leads to scenario-specific calculations during three processes. The three processes are: (1) the insecticide and herbicide production, (2) use of agricultural machinery, and (3) application of fertilizer in the field as described next. (1) In a 100\% scenario, the total energy use of insecticide and herbicide production is assumed as electricity. In a SDS-bio scenario the electricity inputs for the total process of average insecticide and herbicide production are specified while fuel oil and steam inputs are treated as fuel inputs(Audsley et al., 2009). (2) In a 100\% scenario all inputs for agricultural machinery is assumed electricity. In contrast, a SDS-bio scenario treats all such inputs as fuel inputs. (3) In a 100\% scenario all energy for fertilizer application is assumed electricity and in a SDS-bio scenario it is assumed as fuel (Tables A7 - A8).

Table A7. Energy input for bioelectricity production for the two scenarios (GJ ha $\left.{ }^{-1}\right)$.

\begin{tabular}{|c|c|c|c|c|c|c|c|c|c|c|}
\hline \multirow{3}{*}{ Crop } & \multicolumn{2}{|c|}{ Fertilizer } & \multicolumn{2}{|c|}{ Insecticide } & \multicolumn{2}{|c|}{ Herbicide } & $\begin{array}{c}\text { Ag. } \\
\text { machinery }\end{array}$ & Tran. & \multicolumn{2}{|c|}{ Total } \\
\hline & \multicolumn{10}{|c|}{$100 \%$ scenario } \\
\hline & Fuel & Elec. & Fuel & Elec. & Fuel & Elec. & Elec.* & Fuel & Fuel & Elec. \\
\hline Maize & 1.2 & 1.6 & -- & 0.0 & -- & 0.4 & 2.1 & 1.9 & 3.0 & 4.1 \\
\hline Sugar beet & 1.3 & 1.6 & -- & 0.2 & -- & 0.0 & 2.1 & 13.7 & 15.1 & 3.9 \\
\hline Sugarcane & 1.0 & 1.0 & -- & 0.0 & -- & 0.3 & 1.1 & 17.1 & 18.0 & 2.4 \\
\hline Soybean & 0.3 & 0.3 & -- & 0.0 & -- & 0.2 & 2.1 & 1.0 & 1.2 & 2.5 \\
\hline \multirow[t]{2}{*}{ Rapeseed } & 0.5 & 0.8 & -- & 0.0 & -- & 0.1 & 2.1 & 1.0 & 1.5 & 3.0 \\
\hline & \multicolumn{10}{|c|}{ SDS-bio scenario } \\
\hline Maize & 1.4 & 1.4 & 0.0 & 0.0 & 0.2 & 0.2 & 2.1 & 1.9 & 5.5 & 1.6 \\
\hline Sugar beet & 1.6 & 1.4 & 0.1 & 0.1 & 0.0 & 0.0 & 2.1 & 13.7 & 17.5 & 1.5 \\
\hline Sugarcane & 1.1 & 0.8 & 0.0 & 0.0 & 0.1 & 0.2 & 1.1 & 17.1 & 19.4 & 1.0 \\
\hline Soybean & 0.3 & 0.2 & 0.0 & 0.0 & 0.1 & 0.1 & 2.1 & 1.0 & 3.5 & 0.3 \\
\hline Rapeseed & 0.6 & 0.7 & 0.0 & 0.0 & 0.0 & 0.0 & 2.1 & 1.0 & 3.7 & 0.7 \\
\hline
\end{tabular}

Notes: Tran. - refers to biomass transport from field to the power plant. ${ }^{*}$ In SDS-bio scenario it is fuel. 
Table A8. Energy input for biofuel production for the two scenarios specified by the energy type (GJ ha-1).

\begin{tabular}{|c|c|c|c|c|c|c|c|c|c|c|c|c|c|c|}
\hline \multirow{3}{*}{ Crop } & & \multicolumn{2}{|c|}{ Insecticide } & \multicolumn{2}{|c|}{ Herbicide } & \multirow[t]{2}{*}{ Ag. machinery } & \multirow{2}{*}{\multicolumn{2}{|c|}{\begin{tabular}{l|l} 
Tran. 1 & Biorefinery \\
$100 \%$ Scenario \\
\end{tabular}}} & \multirow[t]{2}{*}{ Oil extraction } & \multirow[t]{2}{*}{ Processing } & \multirow[t]{2}{*}{ Tran. 2} & \multicolumn{2}{|c|}{ Total } \\
\hline & \multicolumn{2}{|c|}{\begin{tabular}{|l} 
Fertilizer \\
\end{tabular}} & \multirow[b]{2}{*}{ Fuel } & \multirow[b]{2}{*}{ Elec. } & \multirow[b]{2}{*}{ Fuel } & \multirow[b]{2}{*}{ Elec } & & & & & & & \multirow[b]{2}{*}{ Fuel } & \\
\hline & Fuel & Elec. & & & & & Elec.* & Fuel & Elec. & Elec. & Elec. & Fuel & & Elec. \\
\hline Maize & 1.2 & 1.6 & -- & 0.0 & -- & 0.4 & 2.1 & 0.8 & 18.0 & -- & -- & 0.3 & 2.3 & 22,1 \\
\hline Sugar beet & 1.3 & 1.6 & -- & 0.2 & -- & 0.0 & 2.1 & 9.0 & 0.6 & -- & -- & 0.8 & 11.2 & 4.4 \\
\hline Sugarcane & 1.0 & 1.0 & -- & 0.0 & -- & 0.3 & 1.1 & 10.1 & $0 * *$ & -- & -- & 0.8 & 11.9 & 2.4 \\
\hline Soybean & 0.3 & 0.3 & -- & 0.0 & -- & 0.2 & 2.1 & 0.4 & -- & 3.6 & 2.3 & 0.1 & 0.7 & 8.5 \\
\hline Rapeseed & 0.5 & 0.8 & -- & 0.0 & -- & 0.1 & 2.1 & 0.3 & -- & 2.1 & 2.9 & 0.1 & 0.9 & 7.9 \\
\hline & \multicolumn{14}{|c|}{ SDS-bio scenario } \\
\hline Maize & 1.4 & 1.4 & 0.0 & 0.0 & 0.2 & 0.2 & 2.1 & 0.8 & 18.0 & -- & -- & 0.3 & 4.8 & 19.6 \\
\hline Sugar beet & 1.6 & 1.4 & 0.1 & 0.1 & 0.0 & 0.0 & 2.1 & 9.0 & 0.6 & - & -- & 0.8 & 13.6 & 2.0 \\
\hline Sugarcane & 1.1 & 0.8 & 0.0 & 0.0 & 0.1 & 0.2 & 1.1 & 10.1 & $0^{* * *}$ & -- & -- & 0.8 & 13.3 & 1.0 \\
\hline Soybean & 0.3 & 0.2 & 0.0 & 0.0 & 0.1 & 0.1 & 2.1 & 0.4 & -- & 3.6 & 2.3 & 0.1 & 2.9 & 6.3 \\
\hline Rapeseed & 0.6 & 0.7 & 0.0 & 0.0 & 0.0 & 0.0 & 2.1 & 0.3 & -- & 2.1 & 2.9 & 0.1 & 3.1 & 5.7 \\
\hline
\end{tabular}

Notes: Tran. 1 refers to pre-processing transport while Tran. 2 to post-processing transport. * In SDS-bio scenario it is fuel. ${ }^{* *}$ Energy input for sugarcane processing is offset by generating electricity from bagasse.

Inputs for the remaining stages are treated similar in both scenarios. Specifically, energy inputs in the "transportation" are treated as fuel inputs, while energy inputs for biorefinery, oil extraction and processing are assumed as electricity inputs. Also, energy inputs in three of the four steps of fertilizer production are similar for both scenarios. The four steps of fertilizer production are: (1) production, (2) packaging, (3) transport and (4) application. For step (1) calculations, non-energy use of natural gas in nitrogen fertilizer production is subtracted and the remaining energy inputs are treated as electricity inputs. Phosphorus fertilizer production requires sulphuric acid that is mixed with ground phosphate rock, granulated, etc. (EC, 2007). Thus, $90 \%$ of the input is assumed electricity and $10 \%$ fuel. Potash production requires potassium salts that are mined, milled and transported to production sites where it is crushed, ground, sized and crystallized (Nutrient, 2018). Thus input energy for potash is assumed $60 \%$ electricity and $40 \%$ fuel. Step (2) production of plastic packaging involves extended use of fossil fuels for nonenergy purposes that is assumed $80 \%$ and subtracted while the remaining $20 \%$ of energy input is treated as electricity input. Step (3) all is assumed fuel input, while step (4) differs between the two scenarios (see paragraph above). In both scenarios, non-energy use of fossil-fuels in fertilizer production and packaging are excluded from the total energy inputs.

\section{Part III - final gross bioenergy}

Final gross bioenergy production of circular bioenergy production systems are calculated according to the scheme depicted in Fig. A2. The scheme is an adapted form of the internal loop (Giampietro et al., 2010; Giampietro \& Ulgiati, 2005) and is expressed as:

$$
\left.\begin{array}{l}
\chi-\alpha_{1} \chi-\beta_{1} Y=N B F \\
Y-\alpha_{2} \chi-\beta_{2} Y=N B E
\end{array}\right\}
$$

Where left side of equations are scenario and feedstock specific: $\chi$ is the gross biofuel production in GJ and $Y$ is the gross bioelectricity production in GJ. $\alpha$ and $\beta$ are the production efficiencies calculated as the ratio of input to output in biofuel and 
bioelectricity production. The production efficiencies vary between the feedstock. For biofuel production the efficiencies are calculated using total fuel and electricity input from Table A8 and gross biofuel and bioelectricity output from Table 2.6. ${ }^{4}$ For bioelectricity production the efficiencies are calculated using total fuel and electricity input from Table A7 and gross bioelectricity and biofuel output from Table 2.6. NBF refers to the net biofuel while NBE to the net bioelectricity production. Solving equations for $\chi$ and $Y$ yields the gross biofuel and bioelectricity production for a particular feedstock in a given scenario.

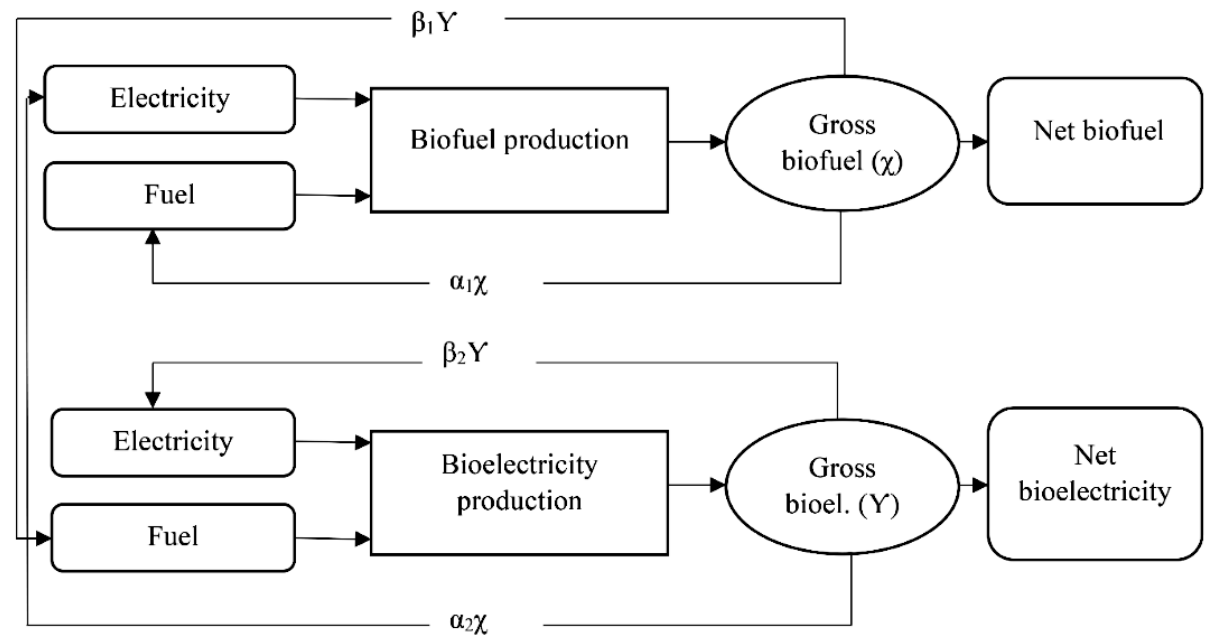

Fig. A2. Schematic representation of the gross energy calculation.

The gross energy production of the system involves two steps. First step is generating bioelectricity through the CHP route until the co-generated heat satisfies the heat demand and then switching to the power only route that achieves higher biomass to bioelectricity conversion efficiency. As such, the equation (1) is used two times: for the CHP generation and then for the bioelectricity generation. The net electricity for the CHP route is determined using the equation (2) and three different net fuel assumptions are tested to select the net fuel amount that results in the lowest gross to net energy ratio. ${ }^{5}$ Next, the remaining bioelectricity and biofuels are generated using the power only route. In the power only route, the net bioelectricity of the CHP route is subtracted from the total net bioelectricity demand. The final gross biofuel and bioelectricity generated in the CHP and power only routes are added and represents the total gross energy (Table A9).

$(1-(0.63 / 0.85)) *($ Total heat $/(0.63 / 0.85))=N B E$

Where total heat is from Table $1 ; 0.63$ is the gross heat output ratio in a CHP route while 0.85 is the total heat + electricity output ratio in a CHP route from Table 2.2.

\footnotetext{
${ }^{4}$ In case of a CHP generation, electricity input is divided by the electricity output of the CHP.

${ }^{5}$ Three different net fuel assumptions are $0 \%, 50 \%$ and $100 \%$ of the net fuel production. The $0 \%$ net fuel production through the CHP route results in lowest overall gross to net ratio and is selected in this study.
} 
Table A9. Gross energy production by scenario and feedstock crops.

\begin{tabular}{|c|c|c|c|c|c|c|}
\hline \multirow{4}{*}{ Crop } & \multirow{4}{*}{ Output type } & \multicolumn{5}{|c|}{ Energy output (GJ) } \\
\hline & & \multicolumn{2}{|c|}{ CHP } & \multicolumn{2}{|c|}{ Electricity only } & \multirow{2}{*}{$\begin{array}{l}\text { Total } \\
\text { Gross }\end{array}$} \\
\hline & & Net & Gross & Net & Gross & \\
\hline & & \multicolumn{5}{|c|}{$100 \%$ scenario } \\
\hline \multirow{2}{*}{ Sugar beet } & Bio & 0 & $4.4 \mathrm{E}+08$ & $4.7 \mathrm{E}+10$ & $8.4 \mathrm{E}+10$ & $8.4 \mathrm{E}+10$ \\
\hline & Bioelectricity & $4.0 \mathrm{E}+09$ & $4.2 \mathrm{E}+09$ & $3.1 \mathrm{E}+11$ & $3.2 \mathrm{E}+11$ & $3.3 \mathrm{E}+11$ \\
\hline \multirow{2}{*}{ Sugarcane } & Biofuel & 0 & $5.1 \mathrm{E}+08$ & $4.7 \mathrm{E}+10$ & $9.0 \mathrm{E}+10$ & $9.1 \mathrm{E}+10$ \\
\hline & Bioelectricity & $4.0 \mathrm{E}+09$ & $4.1 \mathrm{E}+09$ & $3.1 \mathrm{E}+11$ & $3.2 \mathrm{E}+11$ & $3.2 \mathrm{E}+11$ \\
\hline \multirow{2}{*}{ Maize } & Biof & 0 & $2.5 \mathrm{E}+08$ & $4.7 \mathrm{E}+10$ & $6.8 \mathrm{E}+10$ & $6.9 \mathrm{E}+10$ \\
\hline & Bioelectricity & $4.0 \mathrm{E}+09$ & $4.5 \mathrm{E}+09$ & $3.1 \mathrm{E}+11$ & $3.4 \mathrm{E}+11$ & $3.5 \mathrm{E}+11$ \\
\hline \multirow{2}{*}{ Soybean } & Bio & 0 & $4.2 \mathrm{E}+08$ & $4.7 \mathrm{E}+10$ & $8.0 \mathrm{E}+10$ & $8.0 \mathrm{E}+10$ \\
\hline & Bioelectricity & $4.0 \mathrm{E}+09$ & $5.2 \mathrm{E}+09$ & $3.1 \mathrm{E}+11$ & $3.7 \mathrm{E}+11$ & $3.8 \mathrm{E}+11$ \\
\hline \multirow{2}{*}{ Rapeseed } & Bio & 0 & $3.9 \mathrm{E}+08$ & $4.7 \mathrm{E}+10$ & $7.5 \mathrm{E}+10$ & $7.5 \mathrm{E}+10$ \\
\hline & Bioelec & $4.0 \mathrm{E}+09$ & $6.2 \mathrm{E}+09$ & $3.1 \mathrm{E}+11$ & $4.1 \mathrm{E}+11$ & $4.1 \mathrm{E}+11$ \\
\hline & & \multicolumn{5}{|c|}{ SDS-bio scenario } \\
\hline \multirow{2}{*}{ Sugar beet } & Biofuel & 0 & $6.9 \mathrm{E}+08$ & $1.6 \mathrm{E}+10$ & $1.8 \mathrm{E}+10$ & $1.8 \mathrm{E}+10$ \\
\hline & Bioelectricity & $5.6 \mathrm{E}+09$ & $5.7 \mathrm{E}+09$ & $5.5 \mathrm{E}+08$ & $8.0 \mathrm{E}+08$ & $6.5 \mathrm{E}+09$ \\
\hline \multirow{2}{*}{ Sugarcane } & Biofuel & 0 & $7.6 \mathrm{E}+08$ & $1.6 \mathrm{E}+10$ & $1.8 \mathrm{E}+10$ & $1.8 \mathrm{E}+10$ \\
\hline & Bioelectricity & $5.6 \mathrm{E}+09$ & $5.6 \mathrm{E}+09$ & $5.5 \mathrm{E}+08$ & $6.2 \mathrm{E}+08$ & $6.2 \mathrm{E}+09$ \\
\hline \multirow{2}{*}{ Maize } & Bio & 0 & $6.5 \mathrm{E}+08$ & $1.6 \mathrm{E}+10$ & $1.8 \mathrm{E}+10$ & $1.9 \mathrm{E}+10$ \\
\hline & Bioelectricity & $5.6 \mathrm{E}+09$ & $6.0 \mathrm{E}+09$ & $5.5 \mathrm{E}+08$ & $4.5 \mathrm{E}+09$ & $1.1 \mathrm{E}+10$ \\
\hline \multirow{2}{*}{ Soybean } & Biofuel & 0 & $1.7 \mathrm{E}+09$ & $1.6 \mathrm{E}+10$ & $2.1 \mathrm{E}+10$ & $2.3 \mathrm{E}+10$ \\
\hline & Bioelectricity & $5.6 \mathrm{E}+09$ & $6.5 \mathrm{E}+09$ & $5.5 \mathrm{E}+08$ & $5.3 \mathrm{E}+09$ & $1.2 \mathrm{E}+10$ \\
\hline \multirow{2}{*}{ Rapeseed } & Biofuel & 0 & $1.2 \mathrm{E}+09$ & $1.6 \mathrm{E}+10$ & $2.0 \mathrm{E}+10$ & $2.1 \mathrm{E}+10$ \\
\hline & Bioelectricity & $5.6 \mathrm{E}+09$ & $6.8 \mathrm{E}+09$ & $5.5 \mathrm{E}+08$ & $6.6 \mathrm{E}+09$ & $1.3 \mathrm{E}+10$ \\
\hline
\end{tabular}


Table A10. Main characteristics of selected feedstock crops. Source: Gerbens-Leenes et al. (2009a); Gerbens-Leenes et al. (2009b).

\begin{tabular}{|c|c|c|c|c|c|}
\hline & Maize & Sugar beet & Sugar cane & Rapeseed & Soybean \\
\hline Harvest Index & 0.45 & 0.66 & 0.6 & 0.32 & 0.4 \\
\hline Economic Yield & whole tops & beet & whole tops & inflor + seed & beans \\
\hline Dry mass & 0.85 & 0.21 & 0.27 & 0.74 & 0.92 \\
\hline \multicolumn{6}{|c|}{ Composition of dry mass $(\mathrm{g} / 100 \mathrm{~g})$} \\
\hline Carbohydrates & 75 & 82 & 57 & 7 & 29 \\
\hline Proteins & 8 & 5 & 7 & 22 & 37 \\
\hline Fats & 4 & 0 & 2 & 42 & 18 \\
\hline Lignins & 11 & 5 & 22 & 2 & 6 \\
\hline Organic acids & 1 & 4 & 6 & 1 & 5 \\
\hline $\begin{array}{l}\text { Minerals (K, } \\
\mathrm{Ca}, \mathrm{P}, \mathrm{S})\end{array}$ & 1 & 4 & 6 & 26 & 5 \\
\hline Rest fraction & stems & leaves & stems & leaves & leaves \\
\hline Dry mass & 0.85 & 0.21 & 0.27 & 0.13 & 0.15 \\
\hline \multicolumn{6}{|c|}{ Composition of dry mass $(\mathrm{g} / 100 \mathrm{~g})$} \\
\hline Carbohydrates & 62 & 52 & 62 & 52 & 52 \\
\hline Proteins & 10 & 25 & 10 & 25 & 25 \\
\hline Fats & 2 & 5 & 2 & 5 & 5 \\
\hline Lignins & 20 & 5 & 20 & 5 & 5 \\
\hline Organic acids & 2 & 5 & 2 & 5 & 5 \\
\hline $\begin{array}{l}\text { Minerals }(\mathrm{K}, \\
\mathrm{Ca}, \mathrm{P}, \mathrm{S})\end{array}$ & 4 & 8 & 4 & 8 & 8 \\
\hline
\end{tabular}

Table A11. HHV for major plant components. Source: Gerbens-Leenes et al. (2009a); Gerbens-Leenes et al. (2009b).

\begin{tabular}{|l|c|}
\hline Plant component & HHV $\left(G J\right.$ ton $\left.^{-1}\right)$ \\
\hline Fats & 37.7 \\
\hline Lignins & 29.9 \\
\hline Proteins & 22.7 \\
\hline Carbohydrates & 17.3 \\
\hline Organic acids & 13.9 \\
\hline Minerals $(\mathrm{K}, \mathrm{Ca}, \mathrm{P}, \mathrm{S})$ & 0.0 \\
\hline
\end{tabular}


Table A12. The global average WF $\left(\mathrm{m}^{3}\right.$ ton $\left.^{-1}\right)$ of the selected crops. Source: Mekonnen and Hoekstra (2011).

\begin{tabular}{|c|c|c|c|c|}
\hline Crop & Green WF & Blue WF & Grey WF & Total WF \\
\hline Sugar beet & 82 & 26 & 25 & 132 \\
\hline Sugarcane & 139 & 57 & 13 & 210 \\
\hline Maize & 947 & 81 & 194 & 1222 \\
\hline Soybean & 2037 & 70 & 37 & 2145 \\
\hline Rapeseed & 1703 & 231 & 336 & 2271 \\
\hline
\end{tabular}




\section{Appendix B: An Appendix to Chapter 3}

Calculation data for this chapter is available from Zenodo Digital Repository:

https://doi.org/10.5281/zenodo.3600242 


\section{Appendix C. An Appendix to Chapter 4}

Calculation data for this chapter is available from Zenodo Digital Repository:

https://doi.10.5281/zenodo.3941862 


\section{Appendix D. An Appendix to Chapter 5}

Table D1. Available residue bands and assumptions used in previous studies.

\begin{tabular}{|c|c|c|c|c|}
\hline \multirow[b]{2}{*}{ Study } & \multirow[b]{2}{*}{$\begin{array}{l}\text { Scale of } \\
\text { analysis }\end{array}$} & \multirow[b]{2}{*}{ Output(s) } & \multicolumn{2}{|c|}{ Residue availability restrictions } \\
\hline & & & $\begin{array}{c}\text { Environmental } \\
\text { considerations } \\
\text { (e.g. preventing } \\
\text { soil erosion, } \\
\text { organic matter } \\
\text { depletion, soil } \\
\text { carbon, nutrient } \\
\text { loss) }\end{array}$ & $\begin{array}{l}\text { Technical } \\
\text { considerations } \\
\text { (e.g. livestock } \\
\text { bedding; } \\
\text { horticulture; } \\
\text { mushroom } \\
\text { cultivation) }\end{array}$ \\
\hline $\begin{array}{l}\text { Fischer et al. } \\
(2010)\end{array}$ & $\begin{array}{l}\text { EU27 + } \\
\text { Ukraine }\end{array}$ & $\begin{array}{l}\text { Unspecified } \\
\text { biofuels } \\
\text { (Fischer- } \\
\text { Tropsch } \\
\text { conversion } \\
\text { technology) }\end{array}$ & $\begin{array}{l}50 \% \text {, except } \\
\text { vegetables; } 5 \% \text { for } \\
\text { roots and tubers }\end{array}$ & Not considered \\
\hline Eisentraut (2010) & Global & $\begin{array}{l}\text { Bioethanol; } \\
\text { bio-SNG; } \\
\text { btl-diesel }\end{array}$ & Not considered & $10 \%^{*}$ and $25 \% *$ \\
\hline $\begin{array}{l}\text { Scarlat et al. } \\
(2010)\end{array}$ & EU 27 & Heat & $\begin{array}{l}40 \% \text { for wheat, } \\
\text { rye, barley oats; } \\
50 \% \text { for maize, } \\
\text { rice, rapeseed and } \\
\text { sunflower }\end{array}$ & Varies \\
\hline $\begin{array}{l}\text { Portugal-Pereira } \\
\text { et al. (2015) }\end{array}$ & Brazil & $\begin{array}{l}\text { Power } \\
\text { generation }\end{array}$ & $30 \%$ & Varies \\
\hline $\begin{array}{l}\text { Searle and } \\
\text { Malins (2016) }\end{array}$ & EU 28 & $\begin{array}{l}\text { Bioethanol; } \\
\text { biodiesel }\end{array}$ & Maximum of $65 \%$ & Varies $* *$ \\
\hline $\begin{array}{l}\text { Daioglou et al. } \\
(2016)\end{array}$ & Global & Heat & $50 \%$ & $30-40 \%$ \\
\hline
\end{tabular}

Notes: ${ }^{*}$ Assumes using some residue for domestic cooking; ${ }^{* *}$ Assumes using some residue for energy generation (e.g. heat, power, biogas). 
Table D2. Input data for footprint calculations.

\begin{tabular}{|c|c|c|c|c|}
\hline $\begin{array}{l}\text { Footprint } \\
\text { category }\end{array}$ & \multicolumn{2}{|c|}{ Composition } & Value & Source \\
\hline \multirow[b]{3}{*}{$\begin{array}{l}\text { Land } \\
\text { footprint }\end{array}$} & \multirow{2}{*}{$\begin{array}{l}\text { Agriculture } \\
\text { land }\end{array}$} & Area harvested & \multirow{2}{*}{$\begin{array}{l}\text { Five year average: } \\
\text { 2014-2018 (varies by } \\
\text { crop \& country) }\end{array}$} & \multirow{2}{*}{ FAOSTAT (2020) } \\
\hline & & Production & & \\
\hline & $\begin{array}{l}\text { Land footprint } \\
\text { of power grid }\end{array}$ & Electricity mix & $\begin{array}{l}\text { Calculated using } \\
\text { land footprints of } \\
\text { electricity from } \\
\text { specific energy } \\
\text { sources assuming a } \\
\text { global electricity mix } \\
\text { (2018) }\end{array}$ & $\begin{array}{l}\text { IEA (2019d) for } 2018 \\
\text { global electricity mix; } \\
\text { Trainor et al. (2016) } \\
\text { for land footprints of } \\
\text { electricity from } \\
\text { specific energy } \\
\text { sources }\end{array}$ \\
\hline \multirow[b]{3}{*}{$\begin{array}{l}\text { Water } \\
\text { footprint }\end{array}$} & Water footprint & Agriculture & $\begin{array}{l}\text { Ten year average: } \\
\text { 1996-2005 (varies by } \\
\text { crop \& country) }\end{array}$ & $\begin{array}{c}\text { Mekonnen \& } \\
\text { Hoekstra (2011) }\end{array}$ \\
\hline & Water use & Biorefinery & $\begin{array}{l}5.4 \text { gallon gallon }^{-1} \\
\text { ethanol (liter liter-1) }\end{array}$ & Humbird et al. (2011) \\
\hline & $\begin{array}{l}\text { Water footprint } \\
\text { of power grid }\end{array}$ & Electricity mix & $\begin{array}{c}\text { Calculated using } \\
\text { median water } \\
\text { footprints of } \\
\text { electricity from } \\
\text { specific energy } \\
\text { sources assuming a } \\
\text { global electricity mix } \\
\text { (2018) }\end{array}$ & $\begin{array}{l}\text { IEA (2019d) for } 2018 \\
\text { global electricity mix; } \\
\text { Mekonnen et al. } \\
\text { (2015) for water } \\
\text { footprints of } \\
\text { electricity from } \\
\text { specific energy } \\
\text { sources }\end{array}$ \\
\hline \multirow{8}{*}{$\begin{array}{l}\text { Carbon } \\
\text { footprint } \\
\text { (energy } \\
\text { balance) }\end{array}$} & \multirow{5}{*}{$\begin{array}{l}\text { Synthetic } \\
\text { fertilizer } \\
\text { (nitrogen) }\end{array}$} & Manufacture & $69.530 \mathrm{MJ} \mathrm{kg}^{-1}$ & $\begin{array}{c}\text { Gellings \& Parmenter } \\
\text { (2004) }\end{array}$ \\
\hline & & Emissions & $\begin{array}{c}0.9225 \mathrm{~kg} \mathrm{CO}_{2} \mathrm{eq} \mathrm{kg}^{-1 \mathrm{a}} \\
\text { product }\end{array}$ & $\begin{array}{l}\text { Fertilizers Europe } \\
\qquad(2019)\end{array}$ \\
\hline & & $\begin{array}{l}\text { Application } \\
\text { rate }\end{array}$ & $\begin{array}{c}\text { Five year average: } \\
\text { 2014-2018 (varies by } \\
\text { country) }\end{array}$ & FAOSTAT (2020) \\
\hline & & $\begin{array}{c}\text { Direct } \\
\text { emissions }\end{array}$ & \multirow{2}{*}{$\begin{array}{l}\text { Calculated using Tier } \\
1 \text { methodology }\end{array}$} & \multirow{2}{*}{ Tubiello et al. (2015) } \\
\hline & & $\begin{array}{l}\text { Indirect } \\
\text { emissions }\end{array}$ & & \\
\hline & \multirow{3}{*}{ Pesticides } & Manufacture & $370 \mathrm{MJ} \mathrm{kg}^{-1 *}$ & \multirow[b]{2}{*}{ Audsley et al. (2009) } \\
\hline & & Emissions & $\begin{array}{c}0.069 \mathrm{~kg} \mathrm{CO}_{2} \mathrm{eq} \mathrm{MJ}^{-1} \\
\text { product }\end{array}$ & \\
\hline & & $\begin{array}{l}\text { Application } \\
\text { rate }\end{array}$ & $\begin{array}{c}\text { Five year average: } \\
\text { 2014-2018 (varies by } \\
\text { country) }\end{array}$ & FAOSTAT (2020) \\
\hline
\end{tabular}




\begin{tabular}{|c|c|c|c|}
\hline $\begin{array}{l}\text { Cultivation } \\
\text { (rice) }\end{array}$ & $\mathrm{CH}_{4}$ (methane) & $140 \mathrm{~kg} \mathrm{CH}_{4} \mathrm{ha}^{-1}$ & \\
\hline \multirow{6}{*}{$\begin{array}{c}\text { Energy (direct } \\
\text { use for ethanol } \\
\text { production) }\end{array}$} & Mowing & $5 \mathrm{~L}$ (diesel) ha-1** & \multirow[b]{2}{*}{ Dalgaard et al. (2001) } \\
\hline & $\begin{array}{l}\text { Bailing \& } \\
\text { handling }\end{array}$ & $2 \mathrm{~L}$ (diesel) ha-1 & \\
\hline & \multirow{2}{*}{$\begin{array}{l}\text { Residue } \\
\text { transport }\end{array}$} & $\begin{array}{c}\text { 1.37 MJ tonne } \mathrm{e}^{-1} \mathrm{~km}^{-1 \mathrm{~b}} \\
\text { (diesel) }\end{array}$ & \multirow[b]{2}{*}{ Edwards et al. (2017) } \\
\hline & & $\begin{array}{c}0.81 \mathrm{MJ}_{\text {tonne }}^{-1} \mathrm{~km}^{-1 \mathrm{c}} \\
\text { (diesel) }\end{array}$ & \\
\hline & $\begin{array}{l}\text { Electricity } \\
\text { (grinding) }\end{array}$ & $\begin{array}{c}40 \mathrm{kWh}^{\text {tonne }} \mathrm{e}^{-1} \text { (wet } \\
\text { biomass) }\end{array}$ & $\begin{array}{c}\text { German \& Bauen } \\
\text { (2018) }\end{array}$ \\
\hline & $\begin{array}{l}\text { Electricity } \\
\text { (biorefinery) }\end{array}$ & $\begin{array}{c}\text { 3.9 } \mathrm{kWh} \text { gallon }{ }^{-1} \\
\text { ethanol }(1.03 \mathrm{kWh} \\
\left.\text { liter }^{-1}\right)\end{array}$ & Humbird et al. (2011) \\
\hline $\begin{array}{c}\text { Carbon } \\
\text { footprint of } \\
\text { power grid }\end{array}$ & $\begin{array}{l}\text { Power grid } \\
\text { emission factor }\end{array}$ & $\begin{array}{c}\text { Country specific }{ }^{\mathrm{d}}(\mathrm{kg} \\
\left.\mathrm{CO}_{2} \mathrm{eq} \mathrm{kWh}^{-1}\right)\end{array}$ & $\begin{array}{c}\text { IGES (2020); Koffi et } \\
\text { al. (2017); OECD } \\
\text { (2015) }\end{array}$ \\
\hline \multirow{4}{*}{$\begin{array}{l}\text { Energy } \\
\text { (general use for } \\
\text { agricultural } \\
\text { activities) }\end{array}$} & $\begin{array}{l}\text { Ploughing (21 } \\
\mathrm{cm})\end{array}$ & $17 \mathrm{~L}$ (diesel) ha-1** & \multirow{4}{*}{ Dalgaard et al. (2001) } \\
\hline & Sowing & 3.2 L (diesel) ha- ${ }^{-1 * *}$ & \\
\hline & Fertilizing & 1.9 L (diesel) ha-1 & \\
\hline & $\begin{array}{l}\text { Pesticide } \\
\text { spraying }\end{array}$ & 1.2 L (diesel) ha-1 & \\
\hline
\end{tabular}

Notes: * Weighted average for the production of fungicide, herbicide, insecticide, molluscicide, growth regulator, and seed treatment; ${ }^{*}$ Only for crops excluding orchards; ${ }^{a}$ Calculated as average emissions at the plant gate (ammonium nitrate, calcium ammonium nitrate, ammonium nitrosulphate, and calcium nitrate); ${ }^{b}$ Value for the primary crop residue transport is assumed same as 27 tonne load for sugarcane; ${ }^{c}$ Value for secondary crop residue transport is assumed as value commonly used for transport of solids or liquids considering empty return voyage; ${ }^{\mathrm{d}}$ Nationwide (averaged across regions when nationwide is not reported) ex-ante emission factor of existing power plants (for latest available year). 


\begin{tabular}{|c|c|c|c|c|c|c|c|c|c|c|c|c|c|c|c|c|c|c|}
\hline \multirow{8}{*}{ 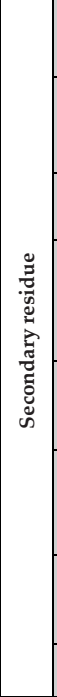 } & 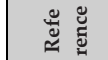 & $\ddot{n}$ & $\tilde{n}$ & $\begin{array}{c}N \\
\dot{n}\end{array}$ & $\ddot{m}$ & $\begin{array}{l}N \\
\ddot{n}\end{array}$ & $\begin{array}{c}N \\
\ddot{n}\end{array}$ & $\begin{array}{l}N \\
\ddot{c}\end{array}$ & $\tilde{m}$ & $\begin{array}{l}\sim \\
\ddot{n}\end{array}$ & & $\ddot{n}$ & $\begin{array}{l}N \\
\ddot{n}\end{array}$ & & $\ddot{\sim}$ & & & \\
\hline & zัँ & & & $\begin{array}{l}\vec{\Xi} \\
\frac{\mathscr{J}}{3} \\
3\end{array}$ & & 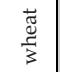 & $\begin{array}{l}\vec{\Xi} \\
\frac{\pi}{3}\end{array}$ & $\begin{array}{l}\text { 节 } \\
\frac{E}{3}\end{array}$ & $\begin{array}{l}\frac{\vec{J}}{3} \\
\frac{\frac{\pi}{3}}{3}\end{array}$ & $\begin{array}{l}\frac{\vec{\Xi}}{\tilde{\pi}} \\
\frac{\pi}{3}\end{array}$ & & $\begin{array}{l}\frac{ \pm}{\mathbb{E}} \\
\frac{5}{3}\end{array}$ & $\begin{array}{l}\overrightarrow{\mathbb{E}} \\
\frac{\tilde{J}}{3}\end{array}$ & & $\begin{array}{l}\text { एँّ } \\
\frac{5}{3}\end{array}$ & & & \\
\hline & $\therefore$ & $\stackrel{\circ}{\circ}$ & 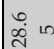 & 号 & - & 琞 & $\stackrel{\leftrightarrow}{\circ}$ & $\stackrel{n}{\circ}$ & $\stackrel{n}{2}$ & $\stackrel{20}{\circ}$ & & $\stackrel{\text { L̊ }}{\circ}$ & 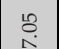 & & $\stackrel{18}{\circ}$ & & & \\
\hline & 茞 & 迥 & 节 & 吕 & $\exists$ & $\begin{array}{l}0 \\
\stackrel{m}{\circ}\end{array}$ & 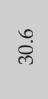 & 迥 & 官 & 迥 & & 迥 & 迥 & & 迥 & & & \\
\hline & 寻 & ذे & तुं & ̇े & $\stackrel{ }{\sim}$ & ذे & ذે & さ્રે & త̀ & త્తి & & తิ & さે & & İ & & & \\
\hline & $\frac{\mathscr{v}}{0}$ & 苟 & 善 & 莒 & ฐ్ّ & 医 & 窇 & 急 & Е & 苞 & & 跑 & ్ㅗㅁ & & 哭 & & & \\
\hline & 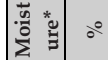 & $\stackrel{2}{\sim}$ & $\stackrel{12}{7}$ & $\stackrel{2}{\rightarrow}$ & $\stackrel{\stackrel{2}{\sim}}{\sim}$ & $\stackrel{2}{\rightarrow}$ & $\stackrel{2}{\sim}$ & 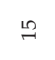 & $\stackrel{12}{\rightarrow}$ & $\stackrel{2}{\longrightarrow}$ & & $\stackrel{2}{7}$ & 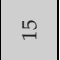 & & 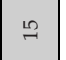 & & & \\
\hline & $\approx \approx$ & 70 & y in & Fः & $7-$ & $ت \pi$ & $\stackrel{3}{0}$ & $\overrightarrow{0}$ & $0_{0}^{\infty} \infty$ & ชุ & & $\begin{array}{ll}-3 & 10 \\
0\end{array}$ & $\begin{array}{lll}\pi & m\end{array}$ & & กี & & & \\
\hline \multirow{10}{*}{ 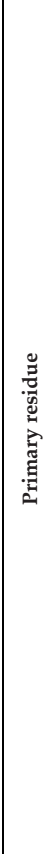 } & ๕ँّ & $\stackrel{N}{=}$ & $\stackrel{N}{=}$ & $\stackrel{N}{=}$ & $\stackrel{\sim}{=}$ & 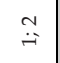 & $\stackrel{N}{=}$ & $\stackrel{\sim}{=}$ & $\stackrel{\sim}{ت}$ & $\stackrel{\sim}{f}$ & $\begin{array}{c}\stackrel{1}{+} \\
\dot{f}\end{array}$ & $\stackrel{f}{+}$ & $\begin{array}{l}\stackrel{N}{+} \\
\dot{f}\end{array}$ & $\begin{array}{l}N \\
\stackrel{+}{*}\end{array}$ & $\stackrel{N}{F}$ & $\stackrel{N}{\mathscr{I}}$ & $\stackrel{\sim}{=}$ & $\stackrel{N}{+}$ \\
\hline & zัٌ & & & & & & & 迅 & & 氖 & 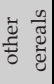 & 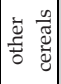 & & 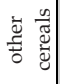 & 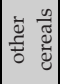 & 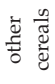 & & 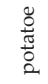 \\
\hline & $\because:$ & $\begin{array}{c}\infty \\
\infty \\
\sim \\
\sim\end{array}$ & 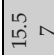 & $\stackrel{\infty}{\sim}$ & लై & $\stackrel{+}{=}$ & 苟 & \pm & $\begin{array}{l}\infty \\
\infty \\
\infty \\
\infty\end{array}$ & $\exists$ & \pm & $\exists$ & $\begin{array}{ll}\infty & \infty \\
\infty & \infty\end{array}$ & $\exists$ & $\exists$ & $\exists$ & & \\
\hline & 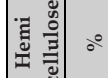 & 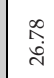 & A & $\begin{array}{l}\text { in } \\
\text { ch } \\
\text { d }\end{array}$ & เุ่ & 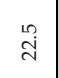 & ते & aे & $\begin{array}{l}\text { ते } \\
\text { ते }\end{array}$ & ढे & बें & बें & 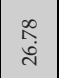 & बें & कें & iे & $\stackrel{\infty}{=}$ & $\stackrel{\infty}{\exists}$ \\
\hline & 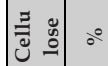 & $\begin{array}{l}\text { fे } \\
\text { ํलㅇ }\end{array}$ & से & $\begin{array}{l}\vec{f} \\
\vec{F}\end{array}$ & 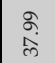 & \begin{tabular}{l|}
$\infty$ \\
$\infty$ \\
$\infty$ \\
$\infty$ \\
$\infty$
\end{tabular} & 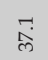 & $\begin{array}{l}\infty \\
\infty \\
\infty\end{array}$ & $\stackrel{10}{70}$ & $\infty$ & $\begin{array}{l}m \\
m \\
\infty\end{array}$ & m & 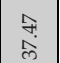 & $\begin{array}{l}m \\
\ddot{\infty}\end{array}$ & $\underset{\infty}{\infty}$ & $\begin{array}{c}m \\
\infty \\
\infty\end{array}$ & $\stackrel{\infty}{\sim}$ & $\stackrel{\infty}{\sim}$ \\
\hline & ஜั̊ & & & & & & & & & & & & & & & & & \\
\hline & 跑 氖 & & & & & & & & & & & & & & & & & \\
\hline & 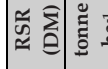 & & & & & & & & & & & & & & & & & \\
\hline & $\tilde{\Xi} \approx$ & $\stackrel{1}{7}$ & $\stackrel{\text { n? }}{\rightarrow}$ & $\Rightarrow$ & $\stackrel{n}{\rightarrow ?}$ & 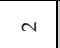 & $\mathrm{N}$ & $m$ & $\begin{array}{ll}4 \\
\text { N }\end{array}$ & $\stackrel{n}{\rightarrow}$ & 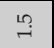 & $\stackrel{\text { n? }}{\rightarrow}$ & $\stackrel{n}{\rightarrow+1}$ & $\stackrel{\text { n? }}{\rightarrow}$ & $\stackrel{\text { n? }}{\rightarrow}$ & $\stackrel{n}{\sim}$ & $\hat{o}$ in & $\stackrel{\circ}{\circ}$ \\
\hline & 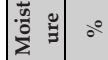 & $\stackrel{2}{2}$ & 는 & $\stackrel{2}{\sim}$ & $\stackrel{2}{\sim}$ & $\stackrel{2}{7}$ & $\stackrel{n}{\sim}$ & $\stackrel{2}{\sim}$ & $\stackrel{12}{7}$ & $\stackrel{2}{\sim}$ & $\stackrel{2}{\longrightarrow}$ & 는 & $\stackrel{12}{7}$ & $\stackrel{2}{7}$ & $\stackrel{2}{7}$ & $\stackrel{2}{\rightarrow}$ & 18 & 18 \\
\hline & 馬 밓 & ż & ż & そ & ż & z & ż & そ̊ & $\stackrel{\circ}{z}$ & z & ż & z & $\stackrel{\circ}{z}$ & $\stackrel{2}{z}$ & z̊ & $\stackrel{2}{z}$ & ż & z̊ \\
\hline & อ๊ ฮี ฮี & & & & & & & & & & & & & & & & & \\
\hline & $\stackrel{\Xi}{\Xi}$ & $\begin{array}{l}\text { बूँ } \\
\underbrace{5}_{3}\end{array}$ & 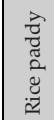 & 摛 & $\stackrel{\check{\tilde{J}}}{\frac{\pi}{\pi}}$ & $\stackrel{8}{2}$ & $\frac{n}{0}$ & 咅 & $\begin{array}{l}\vdots \\
\frac{1}{50} \\
\text { के } \\
\text { के }\end{array}$ & 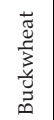 & $\begin{array}{l}\tilde{a} \\
\stackrel{5}{2} \\
0\end{array}$ & 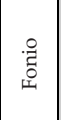 & 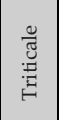 & 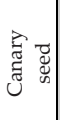 & 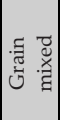 & 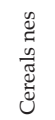 & 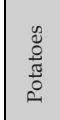 & 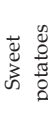 \\
\hline & 皇 & 12 & Aे & 來 & i̊ & 太 & K & হి & $\infty$ & $\infty$ & $\sigma$ & मु & 승 & $\bar{\sigma}$ & 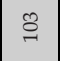 & $\stackrel{\infty}{\stackrel{\sim}{二}}$ & $\stackrel{\varrho}{=}$ & ป \\
\hline
\end{tabular}




\begin{tabular}{|c|c|c|c|c|c|c|c|c|c|c|c|c|c|c|c|c|c|c|}
\hline & & & & & $\begin{array}{l}0 \\
\ddot{m}\end{array}$ & $\begin{array}{l}0 \\
\dot{m}\end{array}$ & $\dot{\ddot{m}}$ & $\ddot{m}$ & $\dot{\ddot{n}}$ & $\dot{\ddot{n}}$ & $\ddot{m}$ & $\dot{m}$ & $\ddot{m}$ & $\dot{\ddot{n}}$ & $\ddot{\text { cे }}$ & $\ddot{m}$ & $\dot{m}$ & $\ddot{\ddot{n}}$ \\
\hline & & & & & 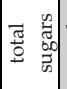 & 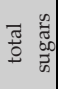 & 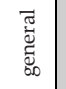 & 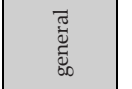 & 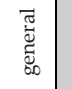 & 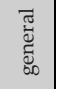 & 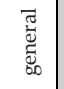 & 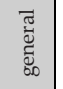 & 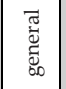 & $\begin{array}{l}\bar{\Xi} \\
\bar{\Xi} \\
\tilde{D}_{0}\end{array}$ & 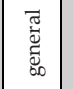 & 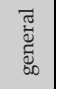 & 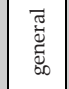 & 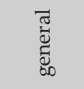 \\
\hline & & & & & & & 솔 & ํㅗㅇ & 究 & ํㅗㄹ & 솔 & 솔 & 열 & 욜 & 옴 & ஸे & م્ & ผิ \\
\hline & & & & & & & 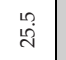 & เి & 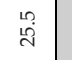 & 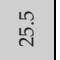 & 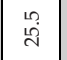 & นึ & $\begin{array}{l}\text { in } \\
\text { ते }\end{array}$ & $\begin{array}{l}\text { ำ } \\
\text { เ્ત }\end{array}$ & मृ & $\begin{array}{l}\text { मn } \\
\text { में }\end{array}$ & $\begin{array}{l}\stackrel{n}{2} \\
\stackrel{\text { in }}{ }\end{array}$ & मृ \\
\hline & & & & & \& & तે & $\stackrel{\text { In }}{\mathfrak{y}}$ & 号 & $\stackrel{\mathscr{H}}{\mathcal{H}}$ & $\stackrel{10}{\mathrm{I}}$ & $\stackrel{n}{\stackrel{n}{y}}$ & นٌ & 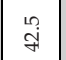 & $\stackrel{\text { In }}{\mathcal{J}}$ & $\stackrel{n}{\mathcal{H}}$ & $\begin{array}{l}\stackrel{n}{\mathcal{j}} \\
\mathfrak{f}\end{array}$ & $\stackrel{n}{\mathfrak{d}}$ & $\stackrel{n}{\mathcal{H}}$ \\
\hline & & & & & 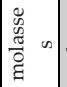 & 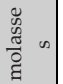 & 点 & 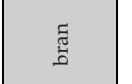 & 莒 & ⿷匚ّ & 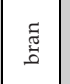 & ฐ్ّ & 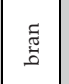 & 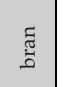 & 营 & 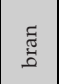 & 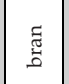 & $\frac{a}{\bar{\nabla}}$ \\
\hline & & & & & $\overleftrightarrow{z}$ & $\overleftrightarrow{z}$ & $\stackrel{2}{2}$ & $\stackrel{2}{2}$ & $\stackrel{2}{2}$ & 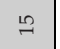 & $\stackrel{2}{2}$ & $\stackrel{2}{2}$ & $\stackrel{2}{2}$ & $\stackrel{20}{2}$ & $\stackrel{2}{2}$ & $\stackrel{2}{2}$ & $\stackrel{2}{2}$ & $\stackrel{2}{2}$ \\
\hline & & & & & $8 \begin{array}{ll}8 & \text { in } \\
\dot{8}\end{array}$ & $\stackrel{8}{\circ}+$ & તุ. & ฮี & בְ. & సૈ. & $\left|\begin{array}{ccc}y & 0 \\
0 & 0 & \infty\end{array}\right|$ & $\mid \begin{array}{ccc}n c & m\end{array}$ & సุ. & సุ & 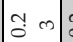 & 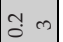 & $\begin{array}{lll}\mid c & m\end{array}$ & $\hat{o}$ \\
\hline$\stackrel{u}{\stackrel{+}{+}}$ & $\stackrel{\cup}{\stackrel{f}{*}}$ & $\begin{array}{c}\breve{u} \\
\dot{x}\end{array}$ & $\begin{array}{c}\stackrel{\dot{x}}{ } \\
\end{array}$ & $\underset{f}{\mathfrak{f}}$ & $\stackrel{n}{\stackrel{n}{*}}$ & $\stackrel{\mathrm{N}}{\rightarrow}$ & $\stackrel{u}{+}$ & $\stackrel{u}{\dot{A}}$ & $\stackrel{u}{\dot{f}}$ & $\stackrel{u}{\dot{f}}$ & $\stackrel{u}{\dot{f}}$ & 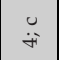 & $\stackrel{u}{\dot{H}}$ & $\stackrel{u}{\dot{+}}$ & $\stackrel{u}{\ddot{i}}$ & $\ddot{\text { is }}$ & $\stackrel{u}{\dot{f}}$ & ثقي \\
\hline 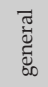 & 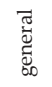 & 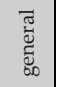 & 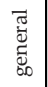 & Еे & Фّ & & 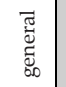 & 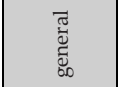 & 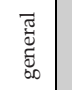 & 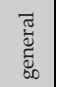 & 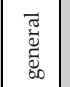 & 焉 & 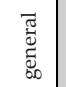 & 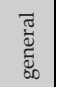 & 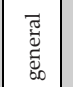 & 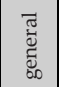 & 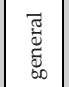 & 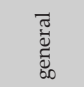 \\
\hline ฝึ่ & $\stackrel{ }{\sim}$ & ํㅗㄹ & فำ & & 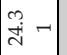 & $\stackrel{\infty}{\stackrel{\infty}{\rightarrow}}$ & ผู & ผุ & ผึ่ & ผ & เి & ผุ & ถุ & ผ & ติ & เి & เ્ & เి \\
\hline 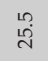 & 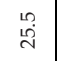 & $\begin{array}{l}10 \\
\text { In } \\
\text { In }\end{array}$ & 总 & N & 忘 & लि. & 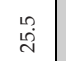 & 号 & 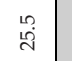 & 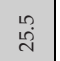 & 号 & 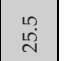 & $\begin{array}{l}\text { 吊 } \\
\stackrel{\text { di }}{ }\end{array}$ & $\begin{array}{l}\text { 吕 } \\
\text { แn }\end{array}$ & 望 & $\begin{array}{l}\text { In } \\
\text { เू } \\
\text { n. }\end{array}$ & 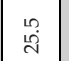 & 呒 \\
\hline $\begin{array}{l}\stackrel{n}{\pi} \\
\stackrel{f}{7}\end{array}$ & $\begin{array}{l}\mathscr{2} \\
\mathscr{q}\end{array}$ & $\begin{array}{l}\stackrel{1}{\mathcal{Z}} \\
\underset{\mathrm{j}}{ }\end{array}$ & \begin{tabular}{l}
$\stackrel{2}{2}$ \\
\multirow{g}{*}{}
\end{tabular} & $\stackrel{m}{\circ}$ & $\underset{F}{\vec{F}}$ & ले & 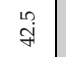 & $\stackrel{\mathscr{I}}{\mathcal{Z}}$ & $\stackrel{\mathscr{L}^{\prime}}{\mathrm{g}}$ & $\stackrel{\stackrel{n}{\mathcal{H}}}{ }$ & $\stackrel{\mathscr{H}}{\mathrm{g}}$ & $\stackrel{n}{\mathscr{g}}$ & $\stackrel{\text { In }}{\stackrel{\text { gl }}{ }}$ & 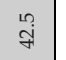 & $\stackrel{\mathscr{H}}{\mathrm{g}}$ & $\stackrel{n}{\mathcal{H}}$ & 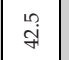 & $\begin{array}{l}\mathscr{L} \\
\mathscr{H}\end{array}$ \\
\hline & & & & & & & & & & & & & & & & & & 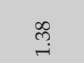 \\
\hline ฮี & ชี & ฮี & กี & $\stackrel{2}{\circ}$ & $\ddot{0}$ & 逭 in & 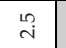 & $\stackrel{4}{4}$ & $\stackrel{\stackrel{n}{\mathrm{~N}}}{\mathrm{~N}}$ & $\stackrel{\mathscr{N}}{\mathrm{N}}$ & $\stackrel{n}{i}$ & in & $\stackrel{\mathscr{n}}{\mathrm{N}}$ & $\stackrel{2}{4}$ & $\stackrel{10}{\mathrm{i}}$ & in & $\stackrel{10}{\mathrm{i}}$ & \\
\hline 18 & 뭉 & 18 & $\ddot{8}$ & 18 & $\stackrel{N}{\kappa}$ & in & 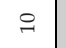 & 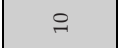 & 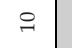 & 욱 & 욱 & 운 & $\stackrel{\circ}{\rightarrow}$ & 욱 & 운 & 운 & 웅 & \\
\hline$\stackrel{\circ}{z}$ & 之 & $\dot{z}$ & 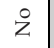 & ż & ż & ż & ż & ż & $\dot{z}$ & $\stackrel{\circ}{z}$ & z & ż & $\stackrel{2}{z}$ & ż & z & $\stackrel{\circ}{z}$ & z & $\stackrel{\mathscr{C}}{\not}$ \\
\hline 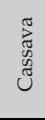 & 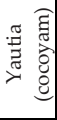 & 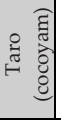 & 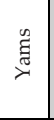 & 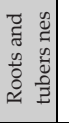 & 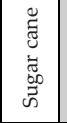 & 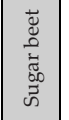 & 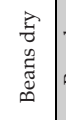 & 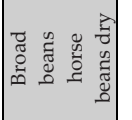 & 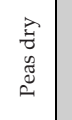 & 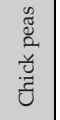 & 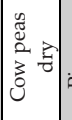 & 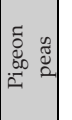 & 号 & 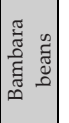 & 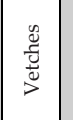 & $\begin{array}{l}\frac{0}{0} \\
\frac{0}{3} \\
3\end{array}$ & 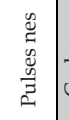 & 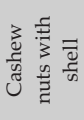 \\
\hline$\stackrel{\stackrel{\beth}{~}}{\sim}$ & $\stackrel{\substack{m \\
\rightarrow}}{\rightarrow}$ & 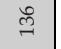 & ले & जे & 党 & की & $\stackrel{2}{2}$ & $\stackrel{\vec{\infty}}{\sim}$ & $\stackrel{\infty}{\rightarrow}$ & $\bar{\sigma}$ & $\stackrel{2}{2}$ & $\stackrel{5}{\sigma}$ & సี & సి & ๙ั & 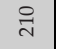 & $\overrightarrow{\text { ง }}$ & ते \\
\hline
\end{tabular}




\begin{tabular}{|c|c|c|c|c|c|c|c|c|c|c|c|c|c|c|c|c|c|c|}
\hline & $\stackrel{n}{n}$ & $\stackrel{n}{\dot{m}}$ & & & $\begin{array}{l}n \\
\dot{m}\end{array}$ & & & $\dot{\ddot{n}}$ & $\begin{array}{l}\text { in } \\
\ddot{n}\end{array}$ & & $\dot{m}$ & $\stackrel{n}{n}$ & & $\ddot{\dot{m}}$ & $\begin{array}{c}u \\
\dot{m}\end{array}$ & $\dot{u}$ & & \\
\hline & & & & & & & & 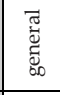 & & & 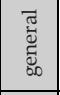 & $\begin{array}{l}\tilde{z} \\
\tilde{\Xi} \\
\tilde{z} \\
. \\
\end{array}$ & & 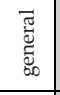 & 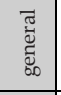 & 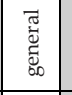 & & \\
\hline & $\infty$ & $\begin{array}{l}\text { n़ } \\
\text { மn }\end{array}$ & & & $\infty$ & & & مै & $\stackrel{\infty}{\sim}$ & & 究 & F & & 룰 & กิ่ & ํㅜㄹ & & \\
\hline & ஓి & Нั่ & & & $\ddot{i}$ & & & $\begin{array}{l}\text { Ln } \\
\text { मूं }\end{array}$ & $\stackrel{\wedge}{\infty}$ & & 毘 & ส & & 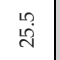 & $\begin{array}{l}\ln ^{2} \\
\stackrel{4}{4}\end{array}$ & 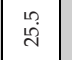 & & \\
\hline & సે & $\stackrel{m}{\vec{d}}$ & & & के & & & $\begin{array}{l}\text { in } \\
\text { g }\end{array}$ & ले & & In & 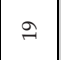 & & 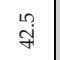 & In & $\stackrel{\mathscr{q}}{\mathscr{q}}$ & & \\
\hline & $\begin{array}{l}\frac{n}{\bar{v}} \\
\frac{\tilde{w}}{\omega}\end{array}$ & $\begin{array}{l}\frac{n}{\bar{v}} \\
\frac{\tilde{m}}{n}\end{array}$ & & & $\frac{m}{\frac{m}{m}}$ & & & 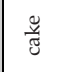 & $\begin{array}{l}\frac{w}{\bar{z}} \\
\frac{\tilde{c}}{\omega}\end{array}$ & & 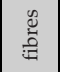 & 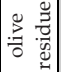 & & है & है & है & & \\
\hline & $\stackrel{20}{2}$ & $\stackrel{2}{2}$ & & & $\stackrel{2}{-1}$ & & & $\stackrel{12}{7}$ & $\stackrel{2}{2}$ & & $\stackrel{2}{2}$ & $\stackrel{2}{2}$ & & $\stackrel{n}{\sim}$ & $\stackrel{2}{2}$ & $\stackrel{2}{7}$ & & \\
\hline & ?2: & $\stackrel{0}{0} \wedge$ & & & "n & & & $\hat{o} a$ & 3 & & Or in & ت艹 & & $\stackrel{0}{0}$ & تُ: $৯$ & : & & \\
\hline$\ddot{0}$ & $\ddot{0}$ & $\ddot{0}$ & ق & ق. & $\ddot{0}$ & $\ddot{\theta}$ & $\ddot{0}$ & $\stackrel{N}{=}$ & $\stackrel{u}{\mathscr{f}}$ & $\ddot{0}$ & $\ddot{0}$ & ق. & ق̈ & $\stackrel{u}{+}$ & $\stackrel{\pi}{\because}$ & $\stackrel{N}{=}$ & قـ & $\stackrel{\cup}{\mathscr{f}}$ \\
\hline 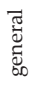 & 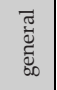 & 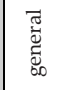 & 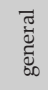 & 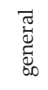 & 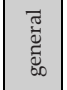 & 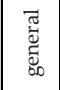 & 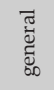 & & 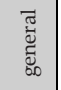 & $\begin{array}{l}\widetilde{\Xi} \\
\stackrel{\Xi}{\square} \\
\square\end{array}$ & 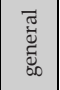 & 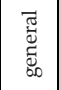 & 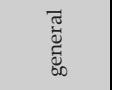 & $\begin{array}{l}\overline{\widetilde{J}} \\
\overrightarrow{\tilde{J}} \\
\mathrm{D}_{0}\end{array}$ & & & 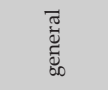 & 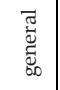 \\
\hline ผู่ & 空 & ผे & ผุ & ำ & ํํำ & ํㅗㄹ & ผे & $\stackrel{2}{\sim}$ & 究 & ฝึ & เ્ & ติ & ผู่ & ํํำ & 㒭 & $\stackrel{m}{g} m$ & ผึ & ํㅐㄹ \\
\hline in & 咓 & 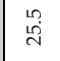 & 華 & $\stackrel{\substack{n \\
\stackrel{N}{N}}}{\stackrel{n}{n}}$ & $\stackrel{\text { in }}{\stackrel{n}{i n}}$ & $\begin{array}{l}\text { Ln } \\
\text { in }\end{array}$ & $\begin{array}{l}\text { मू } \\
\text { में }\end{array}$ & $\stackrel{0}{\sim}$ & 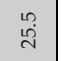 & 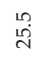 & 望 & 望 & 脬 & $\begin{array}{l}\stackrel{n}{\circ} \\
\stackrel{N}{N}\end{array}$ & in & ส & 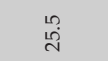 & 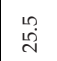 \\
\hline 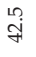 & 年 & $\stackrel{\text { मू }}{\text { H }}$ & $\stackrel{\stackrel{\mathscr{H}}{\mathcal{H}}}{ }$ & $\stackrel{\mathscr{L}}{\mathcal{H}}$ & $\stackrel{\text { g }}{10}$ & $\begin{array}{l}\text { in } \\
\text { I }\end{array}$ & $\begin{array}{l}\text { in } \\
\text { I }\end{array}$ & ڤn & $\stackrel{4}{\mathscr{2}}$ & $\stackrel{\mathscr{H}}{\mathrm{H}}$ & זू & $\stackrel{\text { qn }}{\stackrel{7}{7}}$ & $\stackrel{\text { g }}{\mathrm{g}}$ & $\stackrel{\stackrel{\mathfrak{g}}{\mathfrak{g}}}{2}$ & $\begin{array}{l}\text { R } \\
\text { co } \\
\infty\end{array}$ & ₹ & 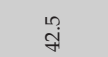 & 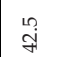 \\
\hline & & & 莫 & 要 & & 宣 & 寄 & & & & & & 节 & & & & 湿 & \\
\hline$\stackrel{\Upsilon}{\longrightarrow}$ & $\stackrel{\leftrightarrow}{s}$ & $\stackrel{\Re}{\stackrel{N}{i}}$ & $\vec{i}$ & $\stackrel{m}{i}$ & $\stackrel{\infty}{\infty}$ & $\stackrel{m}{i}$ & $\stackrel{m}{i}$ & & & + & $\stackrel{\mathscr{L}}{\mathrm{N}}$ & $\begin{array}{c}\tilde{D} \\
\text { i }\end{array}$ & 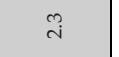 & & & & $\vec{i}$ & \\
\hline Ŝ. & $\stackrel{\text { S }}{-}$ & $\stackrel{\text { ț }}{-}$ & $\stackrel{\infty}{\rightarrow}$ & $\stackrel{\infty}{\rightarrow}$ & $\stackrel{\infty}{\rightarrow+}$ & 离 & 离 & & & $\stackrel{H}{i}$ & $\stackrel{m}{-}$ & فํ. & 离 & & & & $\stackrel{\infty}{\rightarrow}$ & \\
\hline & & & & & & & & $\stackrel{n}{\mathrm{~N}}$ & $\stackrel{2}{\mathrm{~N}}$ & & & & & $\stackrel{\text { 루 }}{\rightarrow}$ & $\underset{i}{i} N$ & $\hat{\lambda}$ in & & $\stackrel{n}{\rightarrow}$ \\
\hline & & & & & & & & $\stackrel{2}{\rightarrow}$ & $\stackrel{n}{\sim}$ & & & & & F & f & F & & F \\
\hline 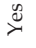 & 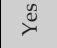 & 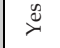 & 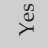 & 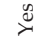 & $\stackrel{\mathscr{\nearrow}}{\varnothing}$ & $\overbrace{>}^{\infty}$ & $\stackrel{0}{0}$ & $\stackrel{2}{z}$ & $\dot{z}$ & 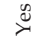 & $\overbrace{>}^{\infty}$ & $\overbrace{\nearrow}^{\infty}$ & 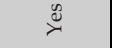 & $\dot{z}$ & ż & ż & 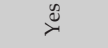 & $\stackrel{\circ}{z}$ \\
\hline & & & & & & & & & & & & & 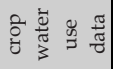 & & & & 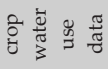 & \\
\hline 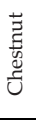 & 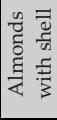 & 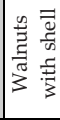 & 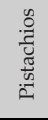 & 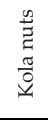 & 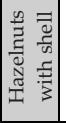 & 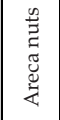 & 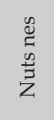 & 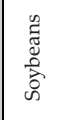 & 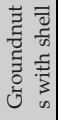 & 号 & 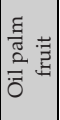 & 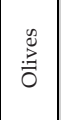 & 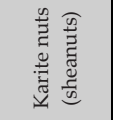 & 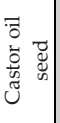 & 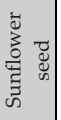 & 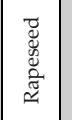 & 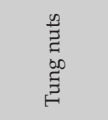 & 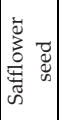 \\
\hline สิ & $\overline{\text { ปี }}$ & สี & สี & ปี & 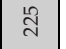 & สี & तु & లై & ปี & अे & 苦 & i & $\stackrel{8}{\mathrm{~d}}$ & 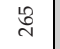 & సे & ลิ & 亭 & $\underset{\sim}{\infty}$ \\
\hline
\end{tabular}




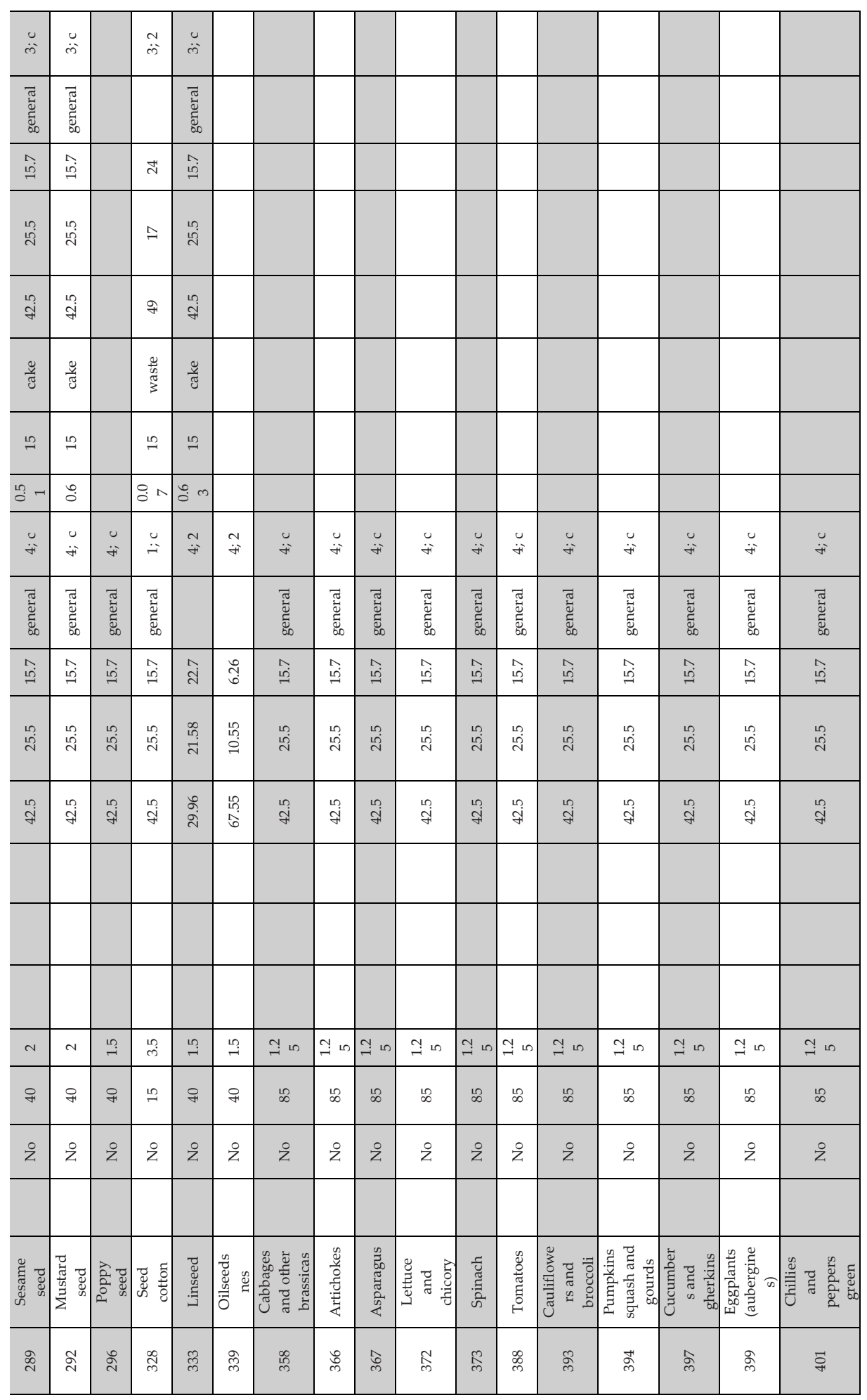




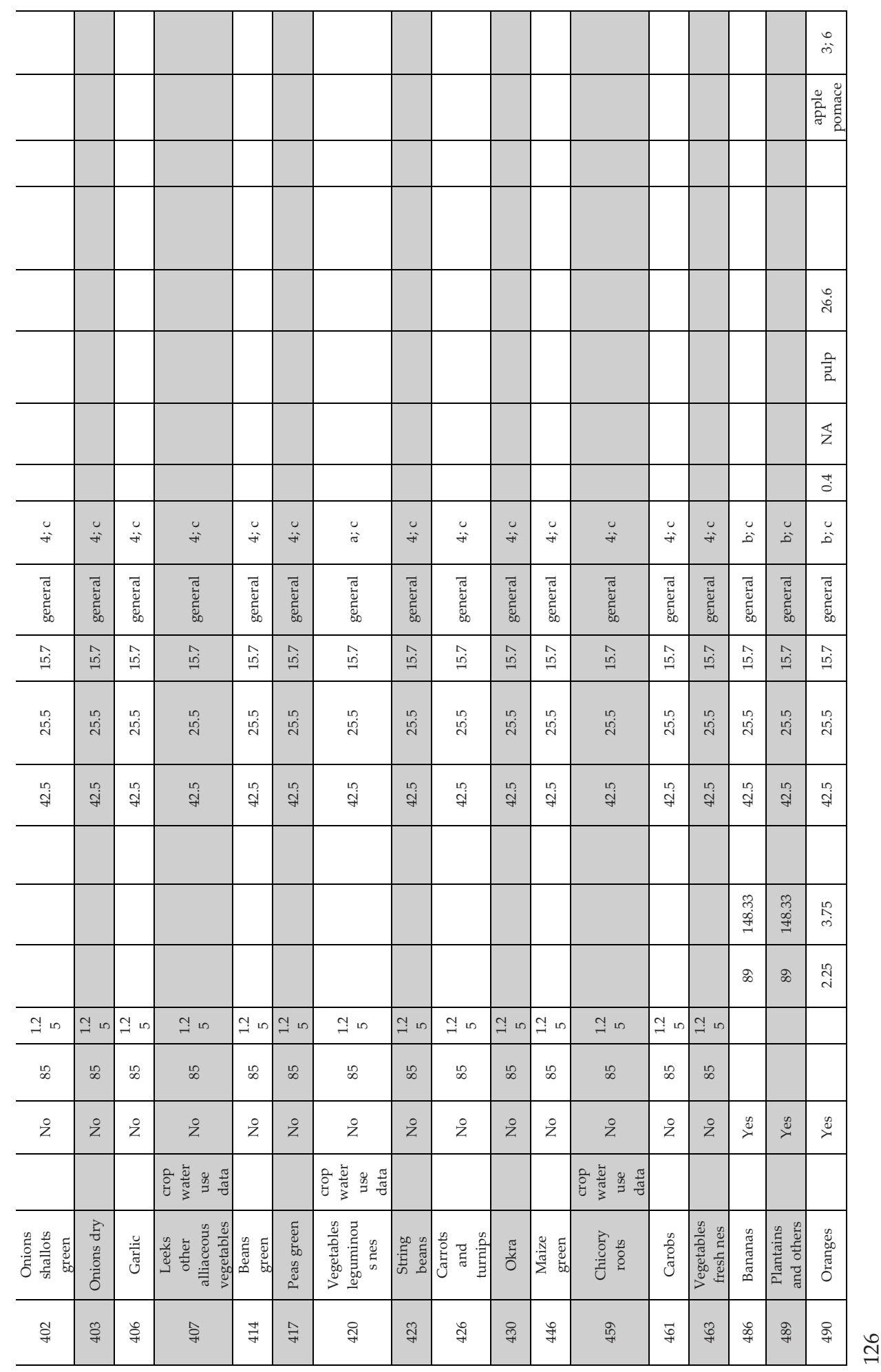




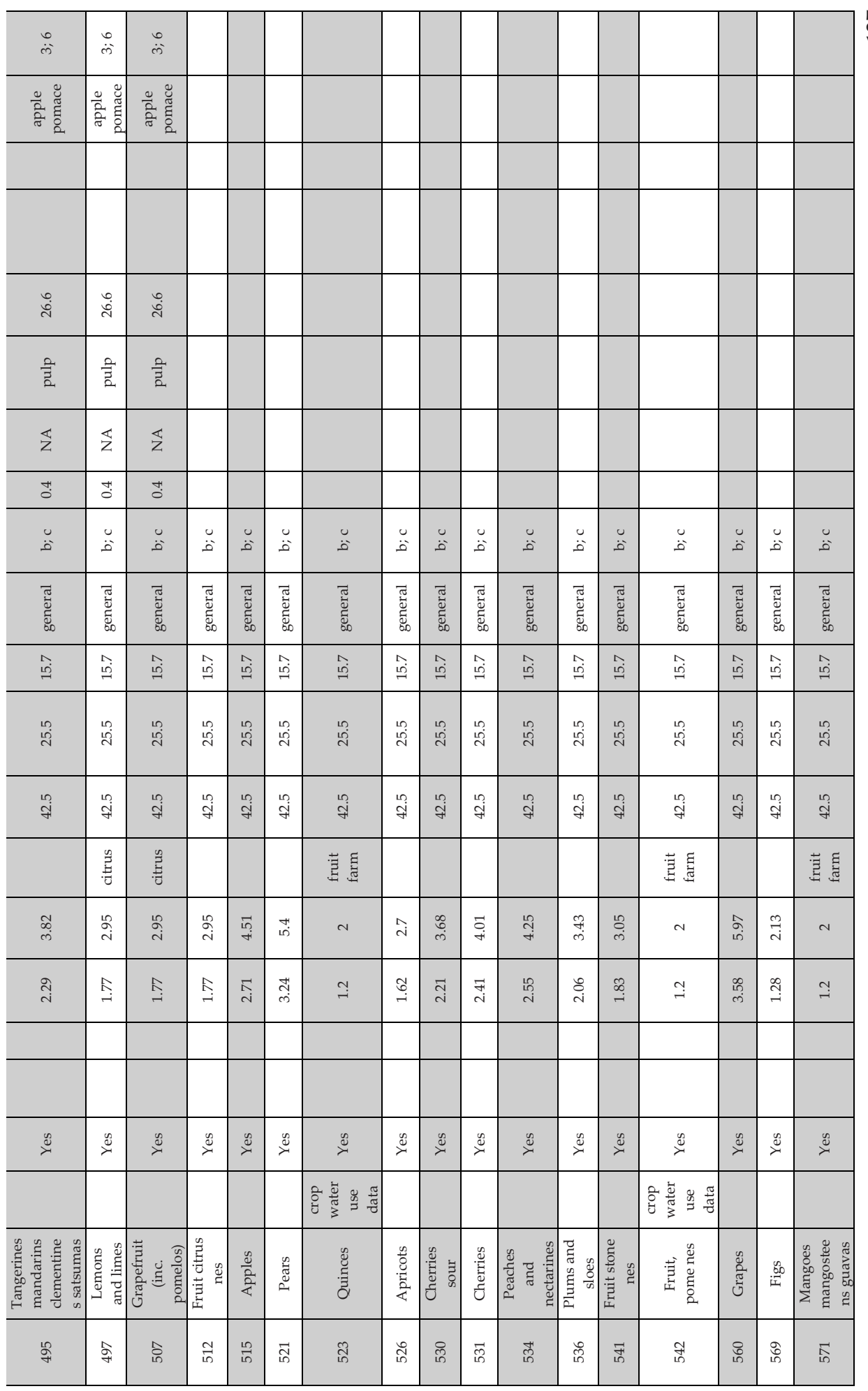




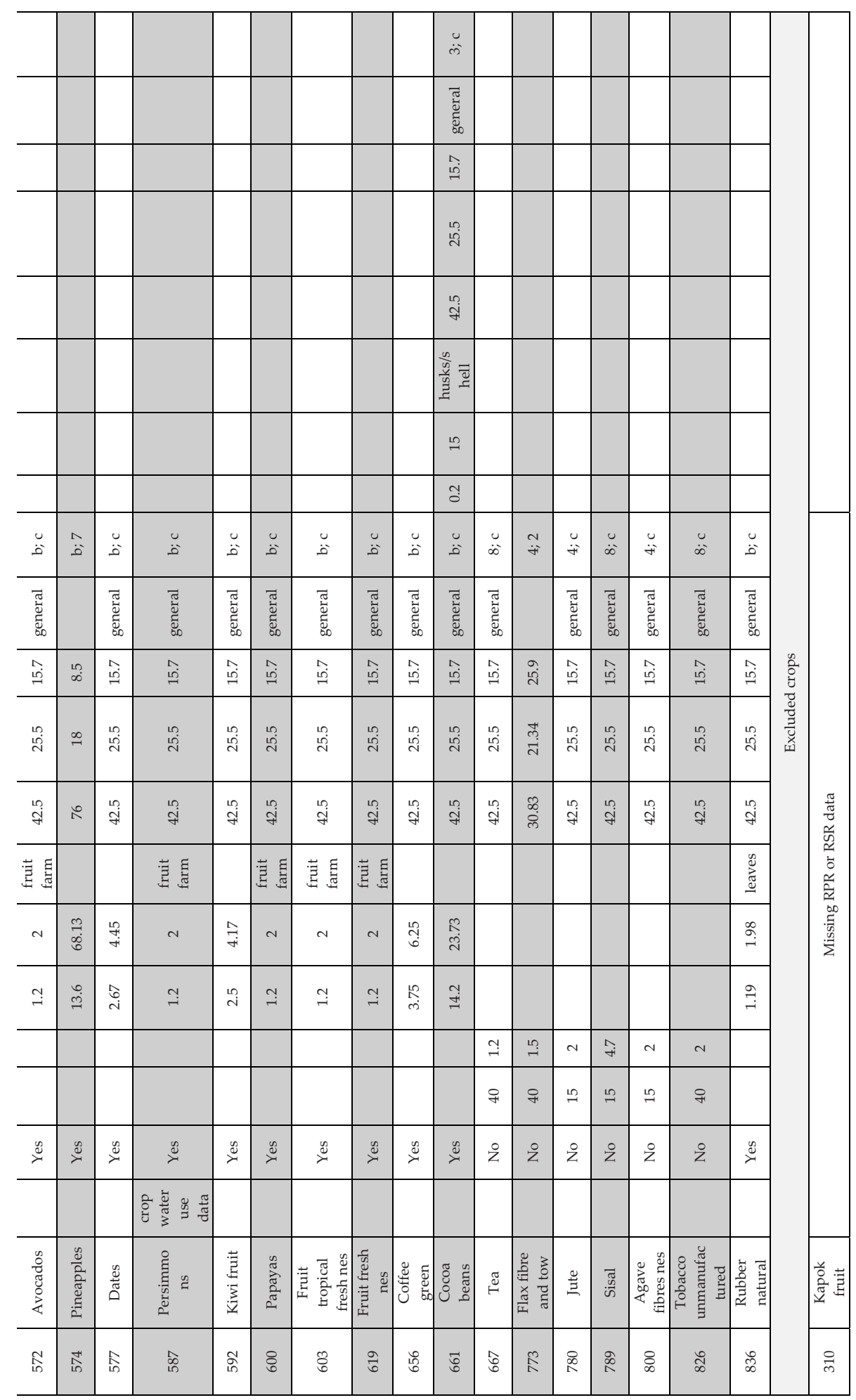




\begin{tabular}{|c|c|c|c|c|c|c|c|c|c|c|c|c|c|c|c|c|c|}
\hline 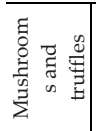 & 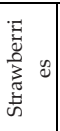 & 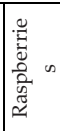 & 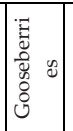 & 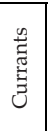 & 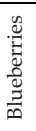 & क & 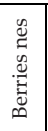 & 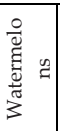 & 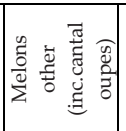 & $\frac{\tilde{J}}{\frac{\pi}{\pi}}$ & 总 & 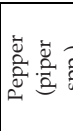 & 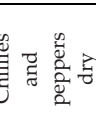 & 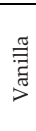 & 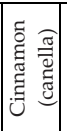 & $\stackrel{\mathscr{0}}{\partial}$ & 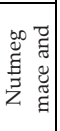 \\
\hline Fे & 费 & 哭 & 암 & 品 & 令 & 莒 & 总 & 总 & 象 & 대 & 合 & ه్రీ & ळి & శ్ & 8 & 总 & $\stackrel{\Sigma}{\curvearrowright}$ \\
\hline
\end{tabular}




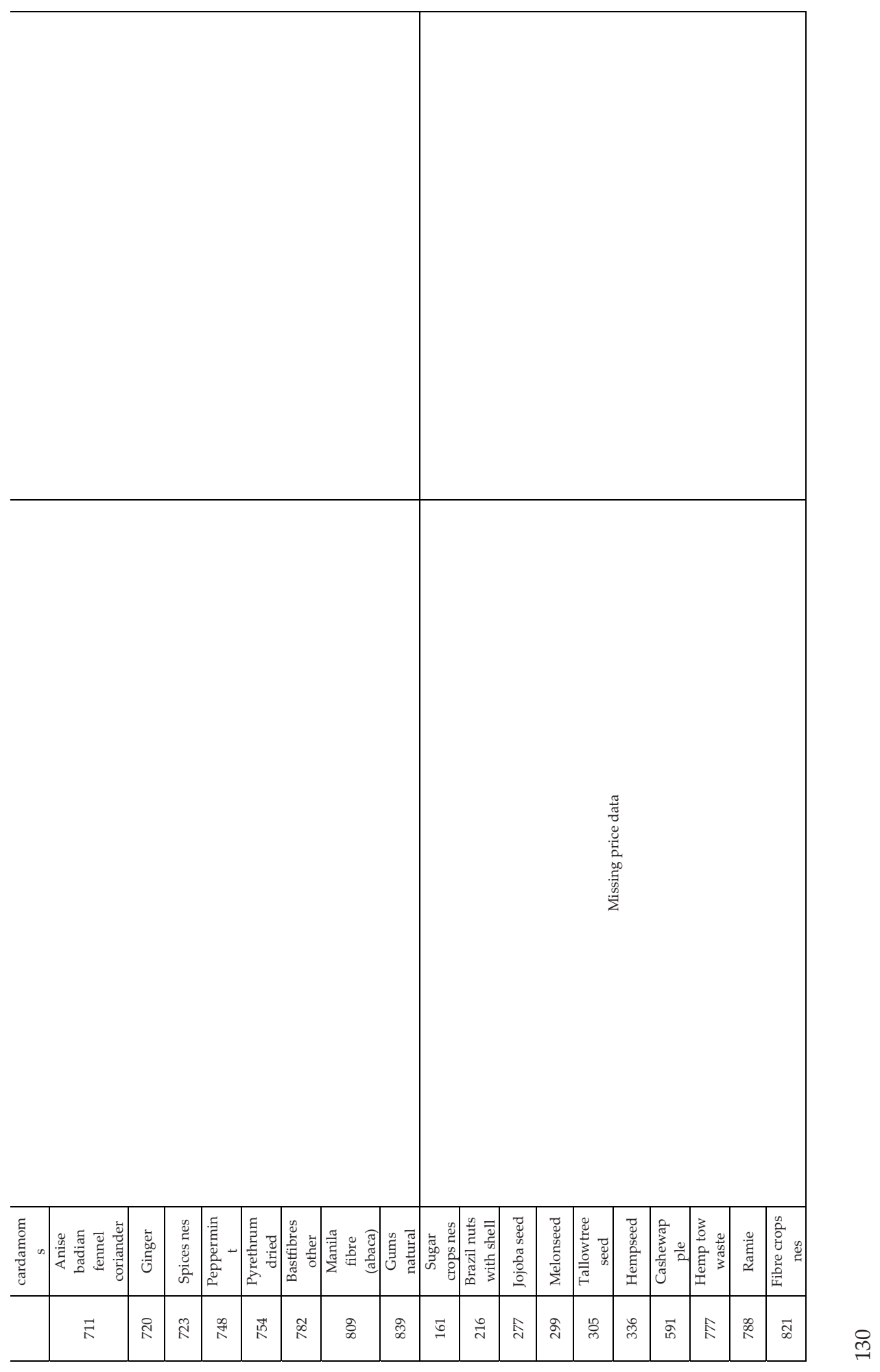




$$
\mid
$$


Table D4. Primary residue availability for orchards.

\begin{tabular}{|c|c|c|c|c|c|c|c|c|}
\hline \multirow[b]{2}{*}{ Orchard } & \multicolumn{3}{|c|}{ Value (tonne ha-1) } & \multicolumn{3}{|c|}{ Reference(s) } & \multicolumn{2}{|c|}{$\begin{array}{c}\text { Utilized } \\
\text { value }\end{array}$} \\
\hline & $\begin{array}{c}\text { Dry } \\
\text { matter } \\
(\mathrm{DM}) \\
\end{array}$ & $\begin{array}{c}\text { Fresh } \\
\text { matter } \\
(\mathrm{FM}) \\
\end{array}$ & $\begin{array}{c}\text { Specific } \\
\text { moisture } \\
(\mathrm{SM})\end{array}$ & DM & FM & SM & $\mathrm{DM}$ & FM \\
\hline Almond & $\begin{array}{c}1.6 \\
\text { (avg); } \\
1.34 ; \\
1.63\end{array}$ & 0.9 (avg) & $6.21(40 \%)$ & $\begin{array}{c}\text { Bilandzija } \\
\text { et al. (2012); } \\
\text { Di Giacomo } \\
\text { and } \\
\text { Taglieri } \\
\text { (2009); } \\
\text { Velázquez- } \\
\text { Martí et al. } \\
\text { (2011) } \\
\end{array}$ & CIRCE (2014) & $\begin{array}{l}\text { Rentizelas } \\
\text { et al. (2009) }\end{array}$ & 1.77 & 2.95 \\
\hline Apple & $\begin{array}{c}1.9 \\
\text { (avg); } \\
2.2 ; \\
0.77 ; 3 ; \\
5.56\end{array}$ & & $4.15(32 \%)$ & $\begin{array}{c}\text { Bilandzija } \\
\text { et al. (2012); } \\
\text { Di Giacomo } \\
\text { and } \\
\text { Taglieri } \\
\text { (2009); } \\
\text { Grella et al. } \\
\text { (2013); } \\
\text { Magagnotti } \\
\text { et al. (2013); } \\
\text { Nati et al. } \\
\text { (2018) }\end{array}$ & & $\begin{array}{l}\text { Pari et al. } \\
\text { (2018) }\end{array}$ & 2.71 & 4.51 \\
\hline Apricot & 1.62 & & & $\begin{array}{l}\text { Bilandzija } \\
\text { et al. (2012) }\end{array}$ & & & 1.62 & 2.70 \\
\hline $\begin{array}{c}\text { Banana } \\
\text { and } \\
\text { plantains }\end{array}$ & 89 & & & $\begin{array}{l}\text { Milbrandt } \\
\text { (2009) }\end{array}$ & & & 89 & 148.33 \\
\hline Citrus & $\begin{array}{c}1.2 \\
\text { (avg) }\end{array}$ & 3.9 (avg) & & $\begin{array}{c}\text { Di Giacomo } \\
\text { and } \\
\text { Taglieri } \\
(2009) \\
\end{array}$ & CIRCE (2014) & & 1.77 & 2.95 \\
\hline Cocoa & 25 & & $4^{a}(13 \%)$ & $\begin{array}{c}\text { Koopmans } \\
\text { and } \\
\text { Koppejan } \\
(1997)\end{array}$ & & $\begin{array}{l}\text { Milbrandt } \\
\text { (2009) }\end{array}$ & 14.2 & 23.73 \\
\hline Coconut & 2.4 & & & $\begin{array}{c}\text { Koopmans } \\
\text { and } \\
\text { Koppejan } \\
(1997)\end{array}$ & & & 2.40 & 4.00 \\
\hline Coffee & $3.75^{\mathrm{b}}$ & & & Beer (1988) & & & 3.75 & 6.25 \\
\hline Cherry & 1.99 & 4.7 (avg) & & $\begin{array}{l}\text { Bilandzija } \\
\text { et al. (2012) }\end{array}$ & CIRCE (2014) & & 2.41 & 4.01 \\
\hline Chestnut & & 1.2 (avg) & & & CIRCE (2014) & & 0.72 & 1.20 \\
\hline Dates & & $4.45^{c}$ & & & $\begin{array}{l}\text { Hosseinkhani } \\
\text { et al. (2014) }\end{array}$ & & 2.67 & 4.45 \\
\hline Figs & 1.28 & & & $\begin{array}{l}\text { Bilandzija } \\
\text { et al. (2012) }\end{array}$ & & & 1.28 & 2.13 \\
\hline
\end{tabular}




\begin{tabular}{|c|c|c|c|c|c|c|c|c|}
\hline Fruit farm & & & $\begin{array}{c}2 \\
\text { (unknown) }\end{array}$ & & & $\begin{array}{c}\text { Fernandes } \\
\text { and Costa } \\
(2010)\end{array}$ & 1.20 & 2.00 \\
\hline Grapevine & $\begin{array}{c}2.9 \\
\text { (avg); } \\
4.26\end{array}$ & & & $\begin{array}{c}\text { Bilandzija } \\
\text { et al. (2012); } \\
\text { Di Giacomo } \\
\text { and } \\
\text { Taglieri } \\
(2009) \\
\end{array}$ & & & 3.58 & 5.97 \\
\hline Hazelnut & 1.85 & 2.3 & & $\begin{array}{l}\text { Bilandzija } \\
\text { et al. (2012) }\end{array}$ & CIRCE (2014) & & 1.85 & 3.08 \\
\hline Kiwi & 2.5 & & & $\begin{array}{c}\text { Grella et al. } \\
\text { (2013) }\end{array}$ & & & 2.5 & 4.17 \\
\hline Mandarine & & & $2.9(21 \%)$ & & & $\begin{array}{c}\text { Velázquez } \\
\text { Martí et al. } \\
(2013)\end{array}$ & 2.29 & 3.82 \\
\hline Olive & $\begin{array}{c}2 \\
\text { (avg); } \\
2.54\end{array}$ & 2.2 (avg) & $\begin{array}{c}1.5 \\
\text { (unknown) }\end{array}$ & $\begin{array}{c}\text { Bilandzija } \\
\text { et al. (2012); } \\
\text { Di Giacomo } \\
\text { and } \\
\text { Taglieri } \\
(2009) \\
\end{array}$ & CIRCE (2014) & $\begin{array}{c}\text { Fernandes } \\
\text { and Costa } \\
(2010)\end{array}$ & 1.69 & 2.82 \\
\hline Orange & & & $2.68(16 \%)$ & & & $\begin{array}{c}\text { Velázquez } \\
\text { Martí et al. } \\
(2013)\end{array}$ & 2.25 & 3.75 \\
\hline $\begin{array}{l}\text { Oil Palm } \\
\text { (fruit) }\end{array}$ & & & $2.6^{\mathrm{d}}(48 \%)$ & & & $\begin{array}{c}\text { Milbrandt } \\
(2009)\end{array}$ & 1.35 & 2.25 \\
\hline Peach & $\begin{array}{c}2.8 \\
(\text { avg); } \\
2.87\end{array}$ & & $\begin{array}{c}2.94 \\
(32.5 \%)\end{array}$ & $\begin{array}{c}\text { Bilandzija } \\
\text { et al. (2012); } \\
\text { Di Giacomo } \\
\text { and } \\
\text { Taglieri } \\
(2009) \\
\end{array}$ & & $\begin{array}{l}\text { Pari et al. } \\
\quad(2018)\end{array}$ & 2.55 & 4.25 \\
\hline Pear & $\begin{array}{c}1.7 \\
\text { (avg); } \\
2.2 ; \\
5.82\end{array}$ & & & $\begin{array}{c}\text { Bilandzija } \\
\text { et al. (2012); } \\
\text { Di Giacomo } \\
\text { and } \\
\text { Taglieri } \\
\text { (2009); } \\
\text { Magagnotti } \\
\text { et al. (2013) }\end{array}$ & & & 3.24 & 5.40 \\
\hline Pineapple & & $\begin{array}{c}112.5 \\
\text { (biennial; } \\
56.25 \\
\text { annual) } \\
\end{array}$ & $80^{\mathrm{e}}(80 \%)$ & & $\begin{array}{c}\text { Hengsdijk } \\
\text { (2018) }\end{array}$ & $\begin{array}{c}\text { Milbrandt } \\
(2009)\end{array}$ & 13.6 & $68.13^{f}$ \\
\hline Plum & 2.06 & & & $\begin{array}{l}\text { Bilandzija } \\
\text { et al. (2012) }\end{array}$ & & & 2.06 & 3.43 \\
\hline Rubber & & & $1.4(15 \%)$ & & & $\begin{array}{c}\text { Milbrandt } \\
(2009)\end{array}$ & 1.19 & 1.98 \\
\hline $\begin{array}{l}\text { Sour } \\
\text { cherry }\end{array}$ & 2.17 & 3.75 (avg) & & $\begin{array}{l}\text { Bilandzija } \\
\text { et al. (2012) }\end{array}$ & CIRCE (2014) & & 2.21 & 3.68 \\
\hline Stone fruit & & 3.05 (avg) & & $\begin{array}{l}\text { CIRCE } \\
(2014)\end{array}$ & & & 1.83 & 3.05 \\
\hline
\end{tabular}




\begin{tabular}{|c|c|c|c|c|c|c|c|}
\hline Dry fruit & 1.38 & & $\begin{array}{c}\text { García- } \\
\text { Galindo et } \\
\text { al. (2019) }\end{array}$ & & 1.38 & 2.3 \\
\hline Walnut & $\begin{array}{c}2.7 \\
(\mathrm{avg}) ; \\
0.54\end{array}$ & $2.8(\mathrm{avg})$ & $\begin{array}{c}\text { Bilandzija } \\
\text { et al. (2012); } \\
\text { Di Giacomo } \\
\text { and } \\
\text { Taglieri } \\
(2009)\end{array}$ & CIRCE (2014) & & & \\
\hline
\end{tabular}

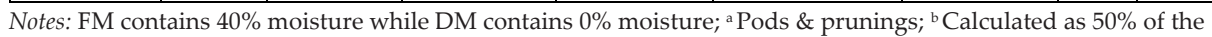
reported range from coffee trees; ${ }^{\mathrm{c}}$ Calculated as $34 \mathrm{~kg}$ residue tree ${ }^{-1}$ and 131 trees ha ${ }^{-1} ;{ }^{\mathrm{d}}$ Fronds; ${ }^{\mathrm{e}}$ Leaves per annum with $80 \%$ moisture content. 


\title{
SENSE
}

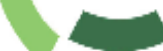

Netherlands Research School for the Socio-Economic and Natural Sciences of the Environment

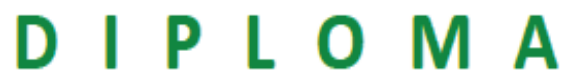

for specialised PhD training

The Netherlands research school for the Socio-Economic and Natural Sciences of the Environment (SENSE) declares that

\section{Bunyod Usmanovich Holmatov}

\author{
born on 5 May 1984 in Kokand, Uzbekistan
}
has successfully fulfilled all requirements of the educational PhD programme of SENSE.

Enschede, 26 November 2020
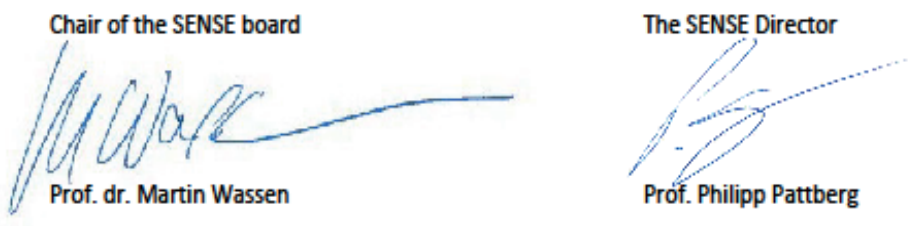

The SENSE Research School has been accredited by the Royal Netherlands Acodemy of Arts and Sciences (KNAW)

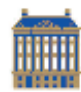

K O

A K A D E M I E V A N W E T E N S C H A P P E N 


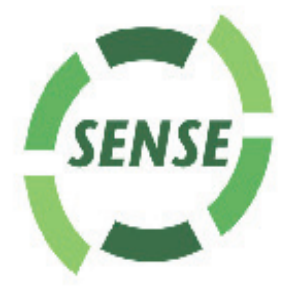

The SENSE Research School declares that Bunyod Usmanovich Holmatov has successfully fulfilled all requirements of the educational PhD programme of SENSE with a work load of 48.3 EC, including the following activities:

\section{SENSE PhD Courses}

- Environmental research in context (2018)

- Research in context activity: 'Establishing an inter-institutional/interagency/intercountry collaboration between Iran and The Netherlands' (2017-2020)

Other PhD and Advanced MSc Courses

- Spatial Databases and their Design, ITC (2017)

- Sixth Groningen Energy Summer School, Groningen University (2017)

- Twente Graduate School Intro PhD Workshop University of Twente (2017)

- Scientific Information: Searching, Managing and Publishing University of Twente (2017)

- Intensive Dutch A1, University of Twente (2018)

- Career orientation and application, University of Twente (2019)

- Nature-based solutions for the management of Rural-Urban Landscapes, University of Malta (2019)

- Data management bootcamp, University of Twente (2020)

- Academic publishing bootcamp, University of Twente (2020)

- Taste of teaching, University of Twente (2020)

\section{Communication initiatives}

- Writing a blog post: Why it is so difficult to measure biofuel emissions, EU MAGIC-NEXUS programme (2019)

\section{Management and Didactic Skills Training}

- Supervising BSc student with thesis entitled 'Present and Future Water Dependencies of Germany's Primary Energy Consumption' (2016-2017)

- Supervising five MSc students with thesis (2016-2020)

\section{Oral Presentation}

- Water-Energy-Food Nexus Case: A global lignocellulosic biofuel production. University of Navarra, 2-3 June 2020, Navarra, Spain.

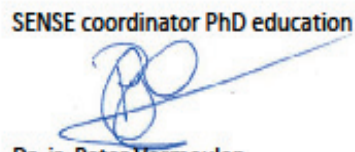

Dr. ir. Peter Vermeulen 


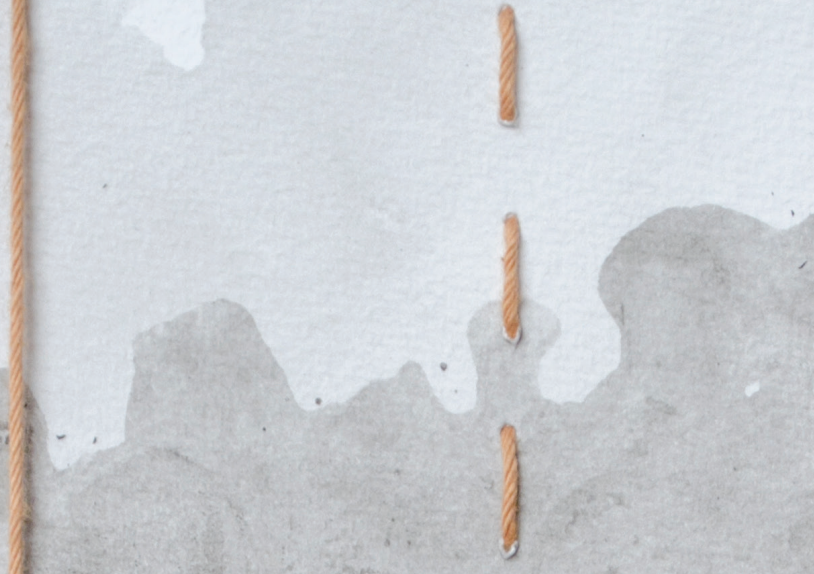